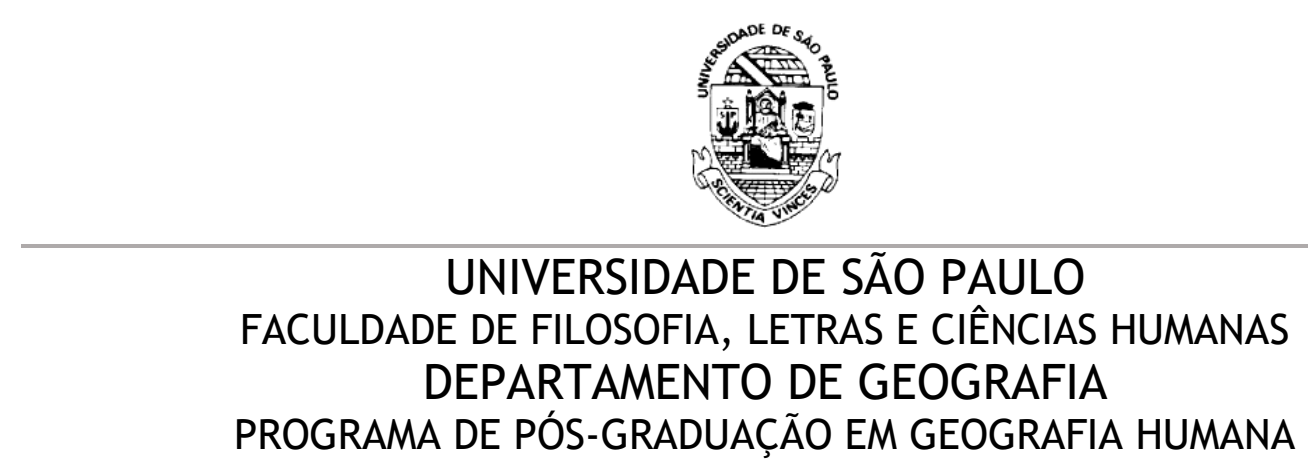

VICTOR ZULIANI IAMONTI

\begin{abstract}
AUTOMAÇÃO BANCÁRIA E FORMAÇÃO SOCIOESPACIAL BRASILEIRA: O CIRCUITO ESPACIAL DE PRODUÇÃO DE TERMINAIS DE AUTOATENDIMENTO (ATMS)
\end{abstract}

Versão Corrigida

São Paulo 
VICTOR ZULIANI IAMONTI

\title{
AUTOMAÇÃO BANCÁRIA E FORMAÇÃO SOCIOESPACIAL BRASILEIRA: O CIRCUITO ESPACIAL DE PRODUÇÃO DE TERMINAIS DE AUTOATENDIMENTO (ATMS)
}

\author{
Dissertação de Mestrado \\ apresentada ao Programa de Pós- \\ Graduação em Geografia Humana \\ da Universidade de São Paulo para \\ obtenção do título de Mestre em \\ Geografia Humana. \\ Orientador: Prof. Dr. Fabio B. \\ Contel
}

De acordo,

São Paulo 
Autarizo a reproduglo 0 dinulgaclo total cu purcial deste trabalbo, per qualquer meio

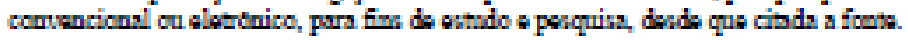

Catalogacilo ma Publicacilo

Serriço de Bibliotaca \& Documeobagho

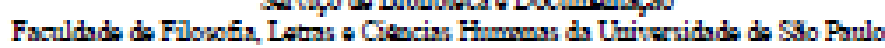

Imenti, Vieter Zulieni

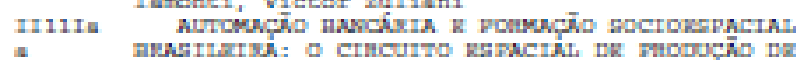

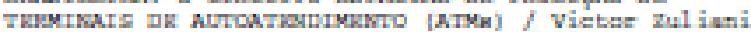

Iunesnti $;$ arientador Vubio Metieli Contel. - Eäo Duulo, 2016.

$17 \mathrm{E}$

Dimaertwẹlib (Mektrwde) - Vweuldade de yilewofia

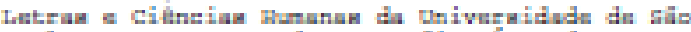
Duulo. Depertumenta de Cerografie. Area de eeneentrwçî́: Ceografie Humuns.

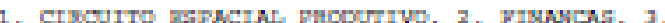
mavece. I. Centel, Vabie Metiali, arient. II. Iitula. 
IAMONTI, V. Z. Automação bancária e formação socioespacial brasileira: o circuito espacial de produção de terminais de autoatendimento (ATMs).

Dissertação apresentada à Faculdade de Filosofia, Letras e Ciências Humanas para obtenção do título de Mestre em Geografia Humana.

Aprovado em:

Banca Examinadora

Prof. Dr. Instituição

Julgamento Assinatura

Prof. Dr. Instituição

Julgamento Assinatura

Prof. Dr. Instituição Julgamento Assinatura 
A Nilton José Iamonti [in memoriam] e a Maria Cristina Zuliani Iamonti 


\section{AGRADECIMENTOS}

Embora a escrita da dissertação seja individual e solitária, o mesmo não pode ser dito do percurso do pesquisador e do processo de pesquisa, que são, felizmente, solidários. Por isso, geralmente, quase todo trabalho contém uma lista de pessoas que, de uma forma ou de outra, participaram direta ou indiretamente de sua elaboração.

Quero começar agradecendo à minha família, por todo apoio nas minhas idas e vindas: à minha mãe, Maria Cristina, e meus irmãos, André e Rafael, por estarem comigo, compartilhando problemas, discussões, aprendizados, além de momentos alegres e tristes.... E aos meus tios e tias, primos e primas, de São Caetano e de Jundiaí pelo apoio e pelas reuniões familiares sempre alegres e festivas.

Ao meu orientador, Prof. Dr. Fabio B. Contel, agradeço por me acolher na pós-graduação e em seu grupo de pesquisa. Também sou grato pela sua orientação rigorosa durante a realização e elaboração dessa dissertação: pelas suas críticas, sugestões e trocas de ideias. Agradeço também pelos aprendizados cotidianos e pelo compartilhamento de suas experiências de ensino e de pesquisa.

À Prof. Dra. Mónica Arroyo, que, sem saber, me inspirou a voltar à geografia ao organizar o evento "Território e Circulação", em 2012. Quero lhe agradecer pelos seus ensinamentos no período de estágio à docência, durante a participação das comissões de organização dos eventos realizados e durante nossas conversas no Departamento de Geografia. Agradeço também pelas trocas de ideias, por compartilhar suas experiências de vida e pelo exemplo de sua luta, cotidiana, por uma América Latina mais justa e solidária.

Ao Prof. Dr. Ricardo Castillo e ao Prof. Dr. Ricardo Mendes, agradeço por suas leituras críticas e sugestões durante o exame de qualificação. Sem dúvida, foram, ambos, importantíssimos para o direcionamento da reta final da pesquisa.

Ao Prof. Dr. Daniel M. Huertas, pelo seu exemplo de comprometimento. Acho que não sabe o quanto me influenciou no final da minha graduação, quando realizava sua pesquisa de mestrado, e, no início do meu período de pós-graduação, 
quando terminava sua pesquisa de doutorado. Lembro até hoje da nossa conversa, nos idos de 2008: "-E aí, o que você vai fazer agora?”. "- Não sei. Estou em dúvida se trabalho ou se tento o mestrado. Qual a sua opinião?”. "- Depende do que você quer para a sua vida. Ser um funcionário de uma repartição ou pensar o país”. Demorei um pouco para escolher a segunda opção e confesso que de vez em quando ainda "titubeio", tendo em vista minhas limitações diante dessa empreitada. Mas tenho consciência que é preciso continuar tentando e seguindo em frente.

Aos amigos e colegas de graduação e de pós-graduação do Departamento de Geografia da USP e da Unicamp, agradeço pelas constantes trocas de ideias e experiências de pesquisas: Antônio, Flávio, Mari, Maíra, Paul, Lúcia, Matheus Sampaio, Aline (Santos), Fábio, Thiago, Carol, Caio, Melissa, A. Pasti, Luciano, Bruno Cândido, Lari, Miriam, Letícia...

Ao Igor e à Aline, agradeço pelas conversas, debates, e incentivos nesse momento de finalização a dissertação. Ao Wagner Nabarro agradeço especialmente pela imensa ajuda na elaboração dos mapas de fluxo e na leitura desse trabalho; sua ajuda foi imprescindível. Ao Rafael Almeida agradeço por me ajudar a sistematizar os dados de comércio exterior do "complicado e perfeitinho" sistema AliceWeb.

Aos amigos que me acompanham desde o início da graduação, em 2004: Ana, Gustavo, Angélica, Dai, Breno, Kauê, Priscila, Camila, Calábria, Marco, Lígia, Bárbara, Leonardo (Mutu)... pelas conversas, risadas, aconselhamentos, discussões e, principalmente, pelas celebrações que tivemos desde que nos tornamos amigos.

À Aninha, que, além de realizar seu trabalho cotidiano no Laboplan, está sempre alegremente disposta para nossas conversas variadas: de aconselhamentos à escuta de angústias; de diálogos sérios sobre os dilemas atuais da Universidade a conversas soltas e divertidas.

Agradeço aos amigos de São Caetano, que me acompanham há um bom tempo: Guilherme, Daniel, Vitor, Márcio, Chrys, Zanin, William (valeu pela ajuda!!), Rixard, Gustavo, Hugo, Evandro, Camila... 
À minha namorada, Raquel, pelo nosso convívio, pelo carinho e por seus incentivos; por entender meus fluxos e refluxos e minha vontade de voltar e de estar na Universidade. Obrigado por ser tão diferente e tão próxima de mim...

Por fim, termino agradecendo ao Conselho Nacional de Desenvolvimento Científico e Tecnológico ( $\mathrm{CNPq}$ ) pelo financiamento de praticamente todo o período de pesquisa, sem o qual, certamente, não teria sido possível chegar aos resultados aqui apresentados. 


\section{IAMONTI, V. Z. Automação bancária e formação socioespacial brasileira: o circuito espacial de produção de terminais de autoatendimento (ATMs). Dissertação (Mestrado), Faculdade de Filosofia, Letras e Ciências Humanas, Universidade de São Paulo, 2016.}

A automação bancária é um fenômeno amplo, que envolve diversos países, atividades econômicas, infraestruturas, agentes e processos. O presente trabalho visa compreendê-la junto das dinâmicas da formação socioespacial brasileira, enquanto sistema técnico composto por artificialidades e intencionalidades, formas de fazer, que funcionam de forma solidária, isto é, utilizando-se e dando condições para que outros sistemas técnicos funcionem (SANTOS, [1996] 2002). Nesse sentido, busca-se analisar criticamente o fenômeno da automação bancária ocorrido no Brasil, dando ênfase na análise do circuito espacial de produção de seus sistemas técnicos, principalmente os Terminais de Autoatendimento (ou Automatic Teller Machines - ATMs), e da difusão e uso destes sistemas pelos bancos instalados no território brasileiro. Dessa forma, foi estabelecida uma periodização, compreendendo o fenômeno em questão a partir de dois grandes períodos (19611991 e 1991-2015) e quatro subperíodos (1961-1974, 1974-1991, 1991-1999 e 19992015). Nesse sentido, formou-se um conjunto de empresas que, apesar de diferentemente localizadas, configuraram um circuito espacial de produção dos Terminais de Autoatendimento e que passaram a fornecê-los aos diversos bancos presentes no Brasil. Tal circuito espacial, em conjunto com os diferentes círculos de cooperação que dele emergem, são de fundamental importância no entendimento de processos de expansão e descentralização espacial de formas de atendimento e de serviços bancários, que, em conjunto com uma crescente bancarização da população, tem favorecido um exponencial aumento do número de ATMs no país.

Palavras-chave: Automação Bancária, Formação Socioespacial Brasileira, Circuito Espacial de Produção de ATMs. 
IAMONTI, V. Z. Banking automation and Brazilian socio-spatial formation: the spatial circuit of production of automated teller machines (ATMs). Dissertação (Mestrado), Faculdade de Filosofia, Letras e Ciências Humanas, Universidade de São Paulo, 2016.

Banking automation is a broad phenomenon that involves several countries, economic activities, infrastructure, agents and processes. This study aims to understand it with the dynamics of the Brazilian socio-spatial formation, as a technical system consisting of artificiality and intentions, ways of doing, that works in solidarity, using and giving conditions for other systems technical work (SANTOS, [1996] 2002). In this sense, the aim is to review the banking automation phenomenon occurred in Brazil, with emphasis on the analysis of spatial circuit production of its technical systems, especially Automated Teller Machines (ATM), and dissemination and use of these systems in banks operating in Brazil. Thus, it was possible to establish a periodization, understanding the phenomenon in question in two major periods (1961-1991 and 1991-2015) and four sub-periods (1961-1974, 1974-1991, 1991-1999 and 1999-2015). In this sense, it formed a group of companies that, although differently located, configured a spatial circuit of production of self-service terminals and now supply them to the various banks operations in Brazil. This spatial circuit, together with the various circles of cooperation that emerged from it, are fundamentally important in understanding the processes of expansion and spatial decentralization of the banking services, which, together with a growing banking population, has favored an exponential increase in the number of ATMs in the country.

Key Words: Banking Automation, Brazillian Socio-Spatial Formation, Spatial Circuit of Production of ATMs. 


\section{LISTA DE FIGURAS, GRÁFICOS, MAPAS, QUADROS E TABELAS}

Figura 1 - Primeiro computador pertencente ao Bradesco (1961)

Figura 2 - Primeiras máquinas dispensadoras de dinheiro e cartão utilizado para saques pelo Bradesco

Figura 3 - Detalhe do terminal e do cartão utilizado pelo Banco Itaú para saque $\quad 20$

Figura 4 - Comunicação de dados por Telex no Banco Bradesco 38

Figura 5 - Centro de Processamento de Dados do Bradesco (anos 1970) 38

Figura 6 - Esquema do Circuito Espacial de Produção de ATMs 98

Gráfico 1 - Balança Comercial Brasileira: Fluxos de importação e exportação de Terminais de Autoatendimento Bancário, de 1997 a 2002 (em US\$)

Gráfico 2 - Brasil: Participação dos Estados na Exportação de ATMs, 1997 a 2002 (em \%)

Gráfico 3 - Balança Comercial Brasileira: Fluxos de importação e exportação de Terminais de Autoatendimento Bancário, de 2003 a 2008 (em US\$)

Gráfico 4 - Brasil: Participação dos Estados na Exportação de ATMs, de 2003 a 2008 (em $\%)$

Gráfico 5 - Balança Comercial Brasileira: Fluxos de importação e exportação de Terminais de Autoatendimento Bancário, de 2003 a 2008 (em US\$)

Gráfico 6 - Brasil: Participação dos Estados na Exportação de ATMs, 1997 a 2002 (em \%)

Gráfico 7 - Evolução da população bancarizada no Brasil (em milhões de pessoas)

Gráfico 8 - Transações em Rede de Terminais ATM por Tipo de Acesso e Função (2006

Gráfico 9 - Quantidade (milhões) de Transações Bancárias por Canais de Acesso 2006 a 2014

Gráfico 10 - Transações Bancárias por Canais de Acesso por Tipo de Operação em 2014

Gráfico 11 - Rede de Terminais ATM: valor das transações (R \$ bilhões) por tipo de função

Gráfico 12 - Crescimento da quantidade de ATMs no Brasil (1999-2015)

Gráfico 13 - Quantidade de ATMs por Estado em 2005

Gráfico 14 - Aumento do número de ATMs entre 2005 e 2015 (em \%) 
Mapa 1 - Importações de ATMs (1997-2002)

Mapa 2 - Exportações de ATMs (1997-2002) 85

Mapa 3 - Importações de ATMs (2003-2008) 88

Mapa 4 - Importações de ATMs (2003-2008) 89

Mapa 5 - Importação de ATMs (2009-2014) 94

Mapa 6 - Exportações de ATMs (2009-2014) 96

Mapa 7 - Quantidade de ATMs por Unidade da Federação (2015) 143

Quadro 1 - Quadro síntese da periodização 4

Quadro 2 - Principais empresas voltadas para produção de objetos técnicos para automação bancária instaladas no Brasil nas décadas de 1970 e $1980 \quad 24$

Quadro 3- Diferenciação do parque instalado de computadores no Brasil 30

Quadro 4 - Quadro síntese dos temas e questões discutidas nos Congressos Internacionais de Automação Bancária (CIAB-FEBRABAN) entre 1991 e 1999, por ano 64

Quadro 5 - Anos 1990: Condições para a ação dos bancos na formação socioespacial brasileira. $\quad 69$

Quadro 6 - Quadro-síntese das principais ações do Estado (1960-2012) para a indústria, ciência e tecnologia

Quadro 7 - Círculos de cooperação estatal: projetos contratados pela FINEP, com participação da empresa Itautec (2004-2011)

Quadro 8 - Quadro síntese dos temas e questões discutidas nos Congressos Internacionais de Automação Bancária (CIAB-FEBRABAN) entre 2000 e 2015, por ano

Quadro 9 - Anos 2000: Condições para a ação dos bancos na formação socioespacial brasileira

Quadro 10 - Tipologia das novas demandas para produção e consumo de ATMs

Tabela 1 - Brasil: Estados Importadores de Terminais de Autoatendimento, 1997 a 2002 (em unidades)

Tabela 2 - Brasil: Estados Importadores de Terminais de Autoatendimento, 2003 a 2008 (em unidades)

Tabela 3 - Brasil: Estados Importadores de Terminais de Autoatendimento, 2003 a 2008 (em unidades)

Tabela 4 - Centros de gestão no território dos 50 maiores bancos no Brasil (dez/1995) 120

Tabela 5 - Centros de gestão no território dos 50 maiores bancos no Brasil (dez/2000) 120

Tabela 6 - Centros de gestão no território dos 50 maiores bancos no Brasil (dez/2011) 122 


\title{
LISTA DE SIGLAS E ABREVIAÇÕES
}

\author{
ADEVAL - Associação de Empresas Distribuidoras de Valores \\ ATM - Terminal de Autoatendimento (automated teller machine) \\ BNDES - Banco Nacional de Desenvolvimento Econômico e Social \\ CCT - Conselho Nacional de Ciência e Tecnologia
}

CIAB/FEBRABAN - Congresso Internacional de Automação Bancária

CNAB - Centro Nacional de Automação Bancária

CNPq - Conselho Nacional de Desenvolvimento Científico e Tecnológico

COBRA - Computadores Brasileiros S.A.

COOPE/UFRJ - Coordenação dos Programas de Pós-Graduação em Engenharia da Universidade Federal do Rio de Janeiro

CPD - Centro de Processamento de Dados

$\mathrm{CPqD}$ - Centro de Pesquisas e Desenvolvimento

CTI - Centro Tecnológico para Informática

DC - Data Center

DPITCE - Diretrizes de Política Industrial, Tecnológica e de Comércio Exterior

EMBRATEL - Empresa Brasileira de Telecomunicações

FEBRABAN - Federação Brasileira das Associações de Bancos

FENABAN - Federação Nacional de Bancos

FINEP - Financiadora de Estudos e Projetos

FNDCT - Fundo Nacional de Desenvolvimento Científico e Tecnológico

FUNTEC - Fundo Nacional de Tecnologia

ITA - Instituto de Tecnologia Aeronáutica

PIN - Personal Identification Number 
PND - Plano Nacional de Desenvolvimento

POLI/USP - Escola Politécnica da Universidade de São Paulo

PROER - Programa de Estímulo à Reestruturação do Sistema Financeiro Nacional

PROES - Programa de Incentivo à Redução do Setor Público Estadual na Atividade Bancária

PUC-RJ - Pontifícia Universidade Católica do Rio de Janeiro

RNP - Rede Nacional de Pesquisa

SUCESU - Sociedade de Usuários de Computadores e Equipamentos Subsidiários

SUDAM - Superintendência para o Desenvolvimento da Amazônia

SUMOC - Superintendência da Moeda e do Comércio

SWIFT - Society for Worldwide Interbank Financial Telecommunications

TCP/IP - Transfer Control Protocol/Internet Protocol

TELEBRÁS - Telecomunicações Brasileira S.A.

TTF - Terminal de Transferência de Fundos

ZFM - Zona Franca de Manaus 
AGRADECIMENTOS III

RESUMO

ABSTRACT VIII

LISTA DE FIGURAS, GRÁFICOS, MAPAS, QUADROS E TABELAS IX

LISTA DE SIGLAS E ABREVIAÇÕES $\quad$ XI

INTRODUÇÃO 1

1. AUTOMAÇÃO BANCÁRIA E A FORMAÇÃO DO CIRCUITO ESPACIAL DE PRODUÇÃO DE ATMS NO BRASIL 13

1.1. OS PRIMEIROS FATORES LIGADOS À AUTOMAÇÃO BANCÁRIA NO BRASIL 13

1.2. AS EMPRESAS NACIONAIS E A DIFUSÃO DA AUTOMAÇÃO BANCÁRIA 21

1.3. Os CíRCULOS DE COOPERAÇÃO: A CONFLUÊNCIA ENTRE INDÚSTRIA DE ALTA TECNOLOGIA E BANCOS NACIONAIS 'SOB MARCHA FORÇADA'

1.4. OS ATMS E AS POSSIBILIDADES DE CIRCULAÇÃO DA INFORMAÇÃo BANCÁRIA NOS ANOS 198031

2. AUTOMAÇÃO BANCÁRIA E O CIRCUITO ESPACIAL DE PRODUÇÃO DE ATMS: DA CRISE DOS ANOS 1980 ÀS REORGANIZAÇÕES DOS ANOS 1990

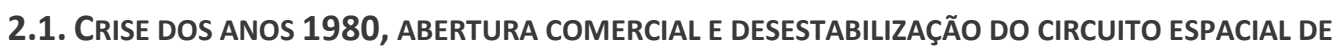
PRODUÇÃO DE ATMS

2.2. A REORGANIZAÇÃo dOS CÍRCULOS DE COOPERAÇÃO NO CONTEXTO NEOLIBERAL 60

2.3. Os ATMS E AS MUDANÇAS NA CIRCULAÇÃO DA INFORMAÇÃO BANCÁRIA NO BRASIL DOS $1990 \quad 66$

3. AS DINÂMICAS RECENTES DO CIRCUITO ESPACIAL DE PRODUÇÃO DE ATMS E A EXPANSÃO DO SISTEMA BANCÁRIO BRASILEIRO NOS ANOS 2000

3.1. OS RECENTES DESDOBRAMENTOS DO CIRCUITO ESPACIAL DE PRODUÇÃO DE ATMS 76

$\begin{array}{ll}\text { 3.2. AS DIFERENCIAÇõES NOS CÍRCULOS DE COOPERAÇÃO } & 109\end{array}$

3.3. BANCARIZAÇÃO DA POPULAÇÃO E A SITUAÇÃO DOS ATMS NA ATUAL GEOGRAFIA DOS FIXOS BANCÁRIOS 


\section{INTRODUÇÃO}

Os terminais de autoatendimento foram projetados e desenvolvidos em meados da década de 1960. É muito difícil determinar quem criou e em qual país, exatamente, foi construído o primeiro terminal. De todo modo, pode-se dizer que os primeiros projetos e equipamentos foram desenvolvidos na Inglaterra, Suécia, Japão e Estados Unidos.

Segundo B. Bátiz-Lazo (2013), a história deste objeto técnico está associada a "uma longa cadeia de inovações - neste caso, originada na ascensão do self-service nos anos 1950 como evidenciados nos postos de gasolina, transporte público, vidros automáticos e máquinas de doces". No Japão, nesse momento, foram criados dispositivos dispensadores de dinheiro ("cash-dispensing devices").

Entretanto, esses terminais só puderam ser utilizados pelos bancos com a invenção do número de identificação pessoal (personal identification number - PIN). $\mathrm{O}$ PIN era um código numérico único, capaz de padronizar e diferenciar cada cliente do banco - até mesmo os que possuíam o nome exatamente igual. Embora tenha sido patenteada pela empresa britânica Chubb, a invenção do PIN foi creditada a James Goodfellow - engenheiro escocês - em 1965.

Ao também escocês John Shepherd-Barron foi atribuída a construção e instalação do primeiro terminal bancário de autoatendimento totalmente operacional em um banco no Reino Unido, em 1967. Sua ideia era a construção de um dispensador semelhante ao de barras de chocolate, mas que, em vez de chocolate, dispensaria dinheiro ${ }^{1}$ (MILLIGAN, 2007).

Um dos motivos para o aumento da demanda por esses projetos e investimentos foi a reação dos bancos europeus "ao aumento da sindicalização e crescentes custos trabalhistas, solicitando aos engenheiros para desenvolver uma solução para os longos períodos de distribuição de dinheiro" (BÁTIZ-LAZO, 2013).

\footnotetext{
${ }^{1}$ Segundo consta em depoimento publicado pelo jornalista B. Milligan (2007) no periódico BBC News, "Pareceu-me que deveria haver uma maneira de obter o meu próprio dinheiro, em qualquer lugar do mundo ou do Reino Unido. Eu tive a ideia de um dispensador de barra de chocolate, mas substituindo o chocolate por dinheiro." ("It struck me there must be a way I could get my own money, anywhere in the world or the UK. I hit upon the idea of a chocolate bar dispenser, but replacing chocolate with cash.").
} 
Para a efetividade do uso desses terminais, no entanto, tornou-se necessária a criação de uma espécie de "sistema operacional" para que os terminais de autoatendimento pudessem reconhecer a conta do cliente por meio do PIN. Daí que essa numeração passou a ser gravada em uma folha de carbono 14 junto a um cartão, para ser posteriormente inserida em uma entrada do terminal capaz de reconhecer as diferentes numerações dos clientes e gravá-la para checagem posterior dos bancos.

Nesse primeiro momento os ATMs eram objetos técnicos de caráter mais "analógico" do que "informacional": era preciso a inserção de um cartão perfurado, contendo a identificação do PIN de acordo com a sequência de furos, ou de marcas. A partir daí, registrava-se o número na bobina de papel e liberava-se o dinheiro em quantidades fixas, determinadas por cada banco.

Aos poucos, houve uma maior complexificação desses objetos técnicos, principalmente com os avanços da informática (de hardware e de software). Seguindo as necessidades bancárias, em 1968 a IBM passou a fazer testes para integração online de terminais deste tipo com um computador central na Suécia. Porém, foi somente em 1972 que estes terminais puderam se conectar a um computador central e trocar informações com uma agência bancária (BÁTIZ-LAZO, 2013). Dessa forma, tornou-se possível não apenas registrar os números dos cartões dos clientes, como também comunicá-los a uma central de dados, que processava as informações, registrava a movimentação e permitia a atualização da conta do cliente.

Além disso, esses avanços favoreceram a criação de novos mecanismos dispensadores de dinheiro, com uma organização interna de forma a diferenciar cédulas e permitir um aumento na flexibilidade dos valores na realização de saques. Assim, a fabricação desses objetos passou a demandar uma maior articulação e complexificação produtiva para sua produção, desde semicondutores, fios elétricos, chips, tela, teclado, mecanismos complexos, cofres e principalmente softwares para operacionalizar sua comunicação, processamento e armazenamento de informações.

As empresas Chubb, De la Rue, Docutel e Asea-Metior e IBM foram as primeiras a fabricar esses equipamentos. Nos anos 1980, com o paulatino abandono 
dos investimentos da IBM nestas máquinas - sendo ela a única empresa com capacidade de dominar o mercado global em função de sua "musculatura" de marketing, expertise de engenharia e rede de negócios -, o setor passou a ser ocupado pelas empresas Borroughs, Diebold, NCR, Phillips, Olivetti e Siemens-Nixdorf, Fujitsu, Hyosung e Hitachi (BÁTIZ-LAZO, 2013).

Pode-se dizer, portanto, que a questão fundamental colocada ao longo da elaboração desse trabalho foi: como, reconhecendo o processo mais geral do início do período técnico-científico informacional (SANTOS, [1996] 2002), seria possível entender o fenômeno de automação bancária $(\mathrm{AB})$ e de formação de um mercado articulado entre produtores e consumidores de ATMs? Como estudar esses processos realizados na formação socioespacial brasileira - e em seus diferentes lugares e regiões? E de que maneira estes processos ofereceram limites e oportunidades para sua realização, participando, dessa maneira, do movimento da formação socioespacial e do período que se iniciava?

Buscando dar respostas sólidas a esta problematização e tornar mais efetiva a análise, a periodização (Quadro 1) foi entendida como recurso do método geográfico, a partir da qual se buscou compreender a especificidade e o entrelaçamento desses processos na formação socioespacial brasileira, além da compreensão e sistematização dos desdobramentos dos eventos ligados à automação bancária $(\mathrm{AB})$ e ao circuito espacial de produção de ATMs.

A incorporação do computador pelos bancos comerciais no Brasil, em 1961, foi considerada, na pesquisa, como o evento-chave, a partir do qual outros eventos desdobraram-se; isso permitiu-nos reconhecer dois grandes períodos e quatro subperíodos em nossa investigação, que não devem ser vistos em uma lógica sequencial estrita. Embora haja uma linearidade na passagem do tempo, pode-se concordar que há um outro aspecto, complementar: como de um período ao outro não houve uma ruptura completa em todos os elementos que coexistiam, admite-se a possibilidade de haver algum tipo de superposição entre elementos de períodos diferentes, forçando a existência nos diferentes lugares de elementos diferentemente datados. 


\section{Quadro 1 - Quadro síntese da periodização}

\begin{tabular}{|c|c|c|c|c|}
\hline & \multicolumn{2}{|c|}{ 1961-1991 } & \multicolumn{2}{|c|}{ 1991-2015 } \\
\hline & 1961-1974 & 1974-1991 & 1991-1999 & 1999-atual (2015) \\
\hline Evento-Chave & $\begin{array}{l}\text { Uso do primeiro } \\
\text { computador em } \\
\text { um banco nacional }\end{array}$ & $\begin{array}{l}\text { Criação da } \\
\text { empresa Cobra - } \\
\text { Computadores } \\
\text { Brasileiros S/A }\end{array}$ & $\begin{array}{l}\text { Abertura de } \\
\text { Mercado à } \\
\text { importação }\end{array}$ & $\begin{array}{l}\text { Compra da empresa } \\
\text { brasileira Procomp pela } \\
\text { Diebold (EUA) }\end{array}$ \\
\hline Normatizações & $\begin{array}{l}\text { Reforma Bancária } \\
\text { de 1964/1965 }\end{array}$ & $\begin{array}{l}\text { I e II Plano } \\
\text { Nacional de } \\
\text { Desenvolvimento } \\
\end{array}$ & PROER/PROES & $\begin{array}{l}\text { Novo Sistema de } \\
\text { Pagamentos Brasileiro }\end{array}$ \\
\hline $\begin{array}{l}\text { Metrópoles } \\
\text { Nacionais }\end{array}$ & $\begin{array}{l}\text { Rio de Janeiro e } \\
\text { São Paulo }\end{array}$ & $\begin{array}{l}\text { São Paulo, Rio de } \\
\text { Janeiro e Brasília }\end{array}$ & $\begin{array}{l}\text { São Paulo, Rio de } \\
\text { Janeiro e Brasília }\end{array}$ & São Paulo e Brasília \\
\hline $\begin{array}{l}\text { Centros de Gestão do } \\
\text { Território (Bancário) }\end{array}$ & $\begin{array}{l}\text { Rio de Janeiro } \\
\text { (principal), São } \\
\text { Paulo, Belo } \\
\text { Horizonte, Curitiba } \\
\text { e Capitais } \\
\text { Estaduais (bancos } \\
\text { Estaduais) }\end{array}$ & $\begin{array}{l}\text { São Paulo } \\
\text { (principal), Rio de } \\
\text { Janeiro, Brasília, } \\
\text { Belo Horizonte, } \\
\text { Curitiba e Capitais } \\
\text { Estaduais (bancos } \\
\text { Estaduais) }\end{array}$ & $\begin{array}{l}\text { São Paulo } \\
\text { (principal), Brasília } \\
\text { e Rio de Janeiro. }\end{array}$ & $\begin{array}{l}\text { São Paulo (principal), } \\
\text { Brasília e Rio de Janeiro. }\end{array}$ \\
\hline $\begin{array}{c}\text { Integração do } \\
\text { Território Nacional }\end{array}$ & $\begin{array}{l}\text { Consolidação da } \\
\text { integração material }\end{array}$ & $\begin{array}{l}\text { Integração material } \\
\text { consolidada. Início } \\
\text { e consolidação da } \\
\text { integração } \\
\text { imaterial }\end{array}$ & $\begin{array}{l}\text { Integração material } \\
\text { e imaterial } \\
\text { consolidadas }\end{array}$ & $\begin{array}{l}\text { Integração material e } \\
\text { informacional } \\
\text { consolidadas }\end{array}$ \\
\hline $\begin{array}{l}\text { Redes-Suporte: } \\
\text { Telecomunicações }\end{array}$ & $\begin{array}{l}\text { Telégrafo, telefone } \\
\text { e cabos submarinos }\end{array}$ & $\begin{array}{l}\text { Telefone, } \\
\text { telemática, } \\
\text { satélites, cabos } \\
\text { submarinos }\end{array}$ & $\begin{array}{l}\text { Telefone, } \\
\text { telemática, } \\
\text { satélites, cabos } \\
\text { submarinos e fibra } \\
\text { ótica }\end{array}$ & $\begin{array}{l}\text { Telefone, telemática, } \\
\text { satélites, cabos } \\
\text { submarinos e fibra ótica }\end{array}$ \\
\hline $\begin{array}{c}\text { Características } \\
\text { principais das } \\
\text { empresas do circuito } \\
\text { espacial de produção } \\
\text { de ATMs }\end{array}$ & $\begin{array}{l}\text { Início da produção } \\
\text { e instalação de } \\
\text { ATMs }\end{array}$ & $\begin{array}{l}\text { Início da produção } \\
\text { e instalação de } \\
\text { ATMs no Brasil; }\end{array}$ & $\begin{array}{l}\text { Continuação da } \\
\text { produção de ATMs } \\
\text { por empresas } \\
\text { brasileiras, porém } \\
\text { em um contexto de } \\
\text { crise operacional. }\end{array}$ & $\begin{array}{l}\text { Entrada de empresas } \\
\text { estrangeiras no circuito } \\
\text { espacial de produção de } \\
\text { ATMs }\end{array}$ \\
\hline $\begin{array}{l}\text { Círculos de } \\
\text { Cooperação }\end{array}$ & $\begin{array}{l}\text { Bancos, } \\
\text { Universidades, } \\
\text { Órgãos Federais e } \\
\text { BNDES }\end{array}$ & $\begin{array}{l}\text { Bancos, } \\
\text { Universidades, } \\
\text { Federações/ } \\
\text { Associações, } \\
\text { Órgãos Federais, } \\
\text { BNDES e } \\
\text { Congressos }\end{array}$ & $\begin{array}{l}\text { Bancos, } \\
\text { Federações/ } \\
\text { Associações, } \\
\text { Congressos. }\end{array}$ & $\begin{array}{l}\text { Bancos, Universidades, } \\
\text { Federações/Associações, } \\
\text { Congressos, BNDES, } \\
\text { FINEP. }\end{array}$ \\
\hline $\begin{array}{l}\text { Estratégia de } \\
\text { Automação }\end{array}$ & $\begin{array}{l}\text { Automação de } \\
\text { "retaguarda" (back } \\
\text { office); Construção } \\
\text { de Centros de } \\
\text { Processamento de } \\
\text { Dados; } \\
\text { Processamento } \\
\text { Centralizado das } \\
\text { Informações }\end{array}$ & $\begin{array}{l}\text { Automação de } \\
\text { "vanguarda" (front } \\
\text { office); Automação } \\
\text { das agências e } \\
\text { desenvolvimento } \\
\text { dos primeiros } \\
\text { ATMs; } \\
\text { Processamento } \\
\text { Centralizado- } \\
\text { Descentralizado } \\
\text { das informações }\end{array}$ & $\begin{array}{l}\text { Integração online } \\
\text { dos fixos bancários; } \\
\text { Início da } \\
\text { automação fora } \\
\text { dos fixos bancários; } \\
\text { Processamento } \\
\text { Centralizado- } \\
\text { Descentralizado } \\
\text { das Informações }\end{array}$ & $\begin{array}{l}\text { Convergência digital e } \\
\text { interoperabilidade dos } \\
\text { fixos; Expansão dos } \\
\text { correspondentes e do } \\
\text { mobile money; } \\
\text { Centralização da gestão } \\
\text { informação bancária em } \\
\text { grandes servidores } \\
\text { ("nuvem"); } \\
\text { Processamento } \\
\text { Centralizado- } \\
\text { Descentralizado das } \\
\text { Informações } \\
\end{array}$ \\
\hline $\begin{array}{l}\text { Objetos técnicos } \\
\text { incorporados }\end{array}$ & Mainframe & $\begin{array}{l}\text { Micro e } \\
\text { Minicomputadores } \\
\text { / ATMs }\end{array}$ & $\begin{array}{l}\text { Internet e Home } \\
\text { Office Banking }\end{array}$ & Mobile Banking e POS \\
\hline
\end{tabular}

Fonte: Elaboração Própria. 
Um dos elementos centrais da lógica da periodização é o entendimento que os sistemas técnicos incorporados em um período podem não encerrar o uso de sistemas e objetos técnicos pertencentes ao período anterior. Ao se instalar no espaço geográfico, os sistemas técnicos são impregnados dos mais diversos conteúdos políticos, normativos, econômicos e culturais. Mas, ao mesmo tempo, permitem novas possibilidades para a instalação de objetos, ações, fluxos e as mais diversas divisões territoriais do trabalho. A coexistência de distintas técnicas e materialidades - diferentemente datadas - diversifica ainda mais as interações e situações geográficas (SANTOS, [1996] 2002).

Buscou-se não perder de vista que cada período foi marcado por uma determinada combinação de variáveis, em que a presença e o desenvolvimento de conteúdos técnicos, políticos e normativos articularam elementos novos e herdados, internos e externos ao território nacional; do mesmo modo, houve processos específicos de automação dentro de cada uma das redes bancárias, que, por sua vez, acabaram por direcionar a incorporação de determinados objetos técnicos.

Neste mesmo sentido, em cada período imbricaram-se formas particulares de organização, tal como foram as "redes" presentes no país. Essas redes foram entendidas como "uma construção social", na qual "indivíduos, grupos, instituições ou firmas desenvolvem estratégias de toda ordem (políticas, sociais, econômicas e territoriais) e se organizam em rede. A rede não constitui o sujeito da ação, mas expressa ou define a escala das ações sociais" (DIAS, 2005, p. 22 e 23). Sendo assim, a rede "conecta diferentes pontos ou lugares mais ou menos distantes permite hoje a ampliação da escala da ação humana até a dimensão global" (DIAS, 2005, p. 23).

Ao longo do tempo, o sistema bancário passou a captar "capitais de diversos pontos do território", decidindo "como e onde investir, numa forma de consolidar a atual divisão territorial do trabalho" (SILVEIRA, 1999, p. 229). Dessa maneira, ao organizar um conjunto de fixos, pode-se entender melhor o que propôs J. Labasse (1974, p. 21), para quem a rede financeira seria "o conjunto hierarquizado e estruturado dos escritórios dirigidos e animados pela sede central de um grande estabelecimento". Essa rede constituiria um núcleo para a circulação de dinheiro, "em sentido único, em detrimento das províncias e em favor das metrópoles" 
(LABASSE, 1955, p. 26). Atualmente, cada vez mais, não só os escritórios fazem parte dessa rede, sendo parte integrante, também, como será visto, os terminais de autoatendimento (ATMs).

Mas há outro fator que terá fundamental importância nas análises empreendidas: trata-se das características da circulação do dinheiro, que, segundo C. Raffestin ([1980], 1993, p. 216) mostraria "muito bem a compenetração quase perfeita da circulação e da comunicação". Para esse autor, a moeda seria "ao mesmo tempo, 'energia cristalizada' e informação"; nesse sentido, haveria, pelas estratégias inerentes ao sistema bancário, a coleta e a distribuição de dinheiro, com uma dupla característica: o dinheiro "'circula', visto ser 'materializado', mas o dinheiro 'comunica', pois também é um sinal, uma ordem" (RAFFESTIN [1980], 1993, p. 216).

A atuação do Estado, por sua vez, foi vista como um elemento crucial, na medida em que suas políticas, diretrizes, normas, planos de desenvolvimento, instituições, entre outros, podem favorecer a presença, concentração e/ou difusão dos agentes econômicos no território (tanto nacionais, quanto estrangeiros). As diferentes ações do Estado permitiram compreendê-lo, igualmente, como um importante regulador do sistema financeiro e de suas respectivas instituições, que, em meio a um complexo processo histórico e junto de determinadas materialidades e topologias, estruturaram parcela considerável das relações e fluxos entre lugares e regiões, espaços nacionais e dinâmicas globais (MARTIN, 1999; SANTOS, 1999).

Do mesmo modo, na medida em que fomos aprofundando o estudo da automação bancária $(\mathrm{AB})$ - e da difusão dos ATMs no território brasileiro - foi ficando evidente para nós que o conceito de circuito espacial de produção seria bastante operacional para a investigação proposta. Podemos entender estes circuitos como "as diversas etapas pelas quais passaria um produto, desde o começo do processo de produção até chegar ao consumo final" (SANTOS, 1988, p. 49). Essas etapas são articuladas junto dos círculos de cooperação, os quais são constituídos pelos fluxos de informação, ordens, capitais etc., permitindo criar uma interdependência nos diferentes espaços produtivos. Acredita-se que essa abordagem conceitual pode permitir compreender com mais clareza o papel do espaço como variável ativa, tendo em vista "o uso diferenciado de cada território 
por parte das empresas, das instituições, dos indivíduos e (...) a hierarquia dos lugares desde a escala regional até a escala mundial" (SANTOS \& SILVEIRA, 2001, p. 144).

$\mathrm{Na}$ formação socioespacial brasileira, esses circuitos espaciais de produção só tiveram condições de se formar após o processo de integração nacional estar completo, ou, ao menos, mais perto de estar consolidado. Esta integração, em grande parte, foi concretizada por uma série de processos, como as políticas de retirada de impostos da circulação interestadual na década de 1930, as políticas de concentração bancária das décadas de 1940-1970, de substituição de importações, a aceleração do processo de urbanização, o processo de industrialização e sua respectiva concentração e diversificação, as transferências de recursos entre unidades agrícolas e industriais, entre outros processos.

Com o alargamento dos contextos da ação das grandes empresas no território, a produção deixou de estar circunscrita à região que a indústria fazia parte e passou a depender de fluxos de diferentes ordens para se completar capitais, dinheiro, mensagens, informação e pessoas. Com a consolidação das regiões produtivas e o início da integração informacional do território, na década de 1970, estabeleceu-se a "passagem" dos circuitos regionais de produção para os circuitos espaciais de produção. Ganhava uma importância cada vez maior a coordenação e o controle de tais fluxos, assim como as condições geográficas da circulação de tais fluxos. Dessa forma, pode-se dizer que, aos circuitos espaciais de produção, foram complementares a articulação "física" (rodoferroviária), "eletrônica" (informacional) e o alargamento dos contextos de realização das atividades econômicas na formação socioespacial brasileira, que garantiram essa nova forma de inserção das diferentes regiões do país nas variadas divisões do trabalho desse novo período do capitalismo (o período técnico-científico informacional, já mencionado).

Para a presente pesquisa, ressalta-se ainda que o circuito espacial de produção de terminais de autoatendimento foi visto como parte constitutiva do complexo eletrônico no país. Esse complexo, envolve "os segmentos eletrônica de consumo, equipamentos de telecomunicações e informática, (...), ao lado dos segmentos de eletrônica embarcada e automação industrial “ (LIMA, 2012). 
No que tange ao circuito estudado, trata-se, dessa forma, de uma especialização produtiva desse complexo. O método de estudo do circuito espacial de produção de ATMs, como integrante do complexo eletrônico, foi semelhante ao de R. M. Antas Jr. (2015), para o estudo dos circuitos espaciais produtivos da saúde:

Então, no caso do complexo industrial da saúde o que analisamos não são setores de um complexo formados por cadeias produtivas, mas constituídos por circuitos espaciais produtivos da saúde e seus círculos de cooperação no espaço. A diferença aqui reside em se orientar por um método que dê instrumentos de análise dos modos de divisões do trabalho especializadas e de alta tecnologia e suas formas de implementação nos territórios (ANTAS JR., 2015, p. 57).

Ao mesmo tempo, o sistema bancário, por conta de suas demandas por objetos e sistemas técnicos para seus diferentes fixos, possui importância semelhante ao que R. M. Antas Jr (2013, p. 6) identificou para o caso dos fixos da saúde, que eram "tratados fundamentalmente como os grandes consumidores, os grandes geradores de demanda, para os quais estão voltados os circuitos espaciais produtivos da saúde".

Assim, como foi visto no Quadro 1, o primeiro período definido para nossa investigação iniciou-se em 1961, com o uso do primeiro computador em um banco no território nacional, e estendeu-se até 1991. Abarcou duas importantes ações do Estado: a Reforma Bancária de 1964/65 e o I e II Plano Nacional de Desenvolvimento. Foi nesse momento, inclusive, que a integração (material e informacional) do território nacional começou a se estabelecer e se consolidar. Divide-se, ainda, em dois subperíodos:

- 1961-1974: embora já houvesse produção de ATMs fora do país, os mesmos ainda não eram fabricados, nem instalados em território nacional; foi, todavia, um importante momento para a estruturação dos agentes que, posteriormente, iriam compor os círculos de cooperação no território;

- 1974-1991: começaram a ser desenvolvidas as primeiras políticas de reserva de mercado e formadas as primeiras empresas nacionais SID, Cobra, Itautec, Procomp, Scopus e TecBan. Com o crescimento destas, pode-se dizer que esse foi importante momento para a 
formação e estruturação do circuito espacial de produção de ATMs em território brasileiro.

O segundo período identificado teve como marco o início da abertura de mercado às importações, em 1991, cujos desdobramentos estendem-se até os dias atuais. Complementarmente à Constituição de 1988, emergiram três outras importantes normatizações que interferiram diretamente no fenômeno estudado: o Programa de Estímulo à Reestruturação e ao Fortalecimento do Sistema Financeiro Nacional (PROER), o Programa de Incentivo à Redução do Setor Público Estadual na Atividade Bancária (PROES) e o novo Sistema de Pagamentos Brasileiro (SPB). Nesse momento, a integração nacional (material e imaterial), já consolidada, expandiu-se com a implantação de novos cabos submarinos e novas redes de fibra ótica. Por fim, pode-se reconhecer a existência neste contexto de outros dois subperíodos:

- 1991-1999: com a abertura de mercado e as dificuldades de estabilização macroeconômica do país, esse subperíodo foi marcado por uma crise operacional das indústrias e bancos nacionais. Culmina no fim da produção de ATMs e equipamentos pela Cobra e nas crises financeiras da Itautec e SID;

- 1999-atual (2015): iniciou-se com a venda da Procomp (maior fabricante nacional à época de equipamentos e computadores) para a empresa Diebold (EUA). Desdobrou-se na falência da SID e em reestruturações sucessivas das indústrias nacionais, destacando-se o caso da Itautec que após passar os anos 2000 reorganizando-se, acabou por ser vendida à indústria japonesa OKI, em 2013. Houve ainda a instalação de fábricas da empresa NCR (EUA) - maior fabricante mundial de ATMs -, em 2004 e novamente em 2009; além disso, destaca-se o crescimento relativo das indústrias nacionais Perto, Tecban e Scopus. Assim, como consequência de todo esse processo de desestabilização e reorganização das empresas nacionais, neste subperíodo as empresas estrangeiras (Diebold, NCR e OKI/Itautec, respectivamente) passaram a dominar o mercado do circuito espacial de produção de ATMs. 
Nesse sentido, pode-se dizer que a automação bancária $(A B)$ tem sido um dos principais fenômenos que contribuem para a produção de novos objetos e sistemas técnicos de todos os tipos ${ }^{2}$, sobretudo aqueles utilizados pelos bancos brasileiros desde meados da década de 1960. Largamente implementada dentro das redes bancárias nas últimas cinco décadas, esta automação contribuiu para alterar não apenas o quadro de realização do trabalho dentro das agências, como também as possibilidades e ritmos de fluxos de informação e de dinheiro entre elas no território nacional.

Embora a progressiva substituição de rotinas de trabalho manual por rotinas de trabalho realizadas majoritariamente por intermédio de dispositivos eletrônicos e programas computacionais tenha sido um aspecto marcante dos distintos processos de automação, não se pode reduzi-los a este único aspecto. Por sua complexidade, considerou-se que envolvem, pelo menos, o entendimento de outras quatro características: 1) realização de uma ação a partir de um determinado posicionamento/localização; 2) controle dos meios de execução das ações bastante eficiente; 3) uso de programas de computação com instruções de cada processo e no comando de toda a operação, com meios de identificar, medir e reportar o que está sendo processado; 4) elementos de tomada de decisão capazes de fazer correções adequadas para os eventuais desvios (BARIC, 1996).

Assim, buscou-se, no presente trabalho, compreender o desdobramento desse processo de automação bancária na formação socioespacial brasileira considerando três principais pontos:

1. Embora seja uma condição necessária, mas não exclusiva, para a ação dos bancos no território, entendeu-se que, ao ser implementada, a automação bancária $(\mathrm{AB})$ contribuiu para dar novos conteúdos aos meios geográficos das diferentes situações geográficas da formação socioespacial brasileira. Ao mesmo tempo, foi constantemente influenciada por projetos governamentais, configurações e estratégias territoriais do sistema bancário, diferenciações das infraestruturas

\footnotetext{
${ }^{2} \mathrm{O}$ conceito de sistemas técnicos tem como fundamento o fato das técnicas serem, ao mesmo tempo, objetos e formas de fazer e de regular. Para tanto, devem (as técnicas) ser "solidárias", isto é, utilizandose de outras técnicas e dando condições para que outras técnicas funcionem (SANTOS, [1996] 2002). Acredita-se que o estudo dos sistemas técnicos pode elucidar uma multiplicidade de processos territoriais de integração, flexibilidade, organização, normatização, aumento de produtividade das empresas etc.
} 
(principalmente as redes de telecomunicações) e desigualdades regionais pré-existentes, que, em muitos casos, contribuíram para as atividades e processos relacionados à automação bancária (doravante, $\mathrm{AB}$ ) se inserirem nos contextos de urbanização, industrialização e de desenvolvimento tecnológico nacional.

2. $\mathrm{A} A \mathrm{AB}$ não foi estudada pela classificação de setores da economia, na medida em que, a despeito dos diferentes casos existentes, houve uma imbricação entre indústria de alta tecnologia (setor secundário), sistema bancário e serviços corporativos sofisticados (setores terciário e quaternário, respectivamente). Buscando superar esta dificuldade, foram operacionalizados os conceitos de circuito espacial de produção e de sistemas técnicos. Desta maneira, foi possível estudá-la geograficamente, desde à montante do sistema bancário - o circuito espacial de produção -, quanto à jusante - o consumo dos objetos técnicos (sobretudo os ATMs) e sua incorporação nos sistemas técnicos automatizados dos bancos.

3. Nosso recorte empírico mais específico foi o estudo dos Terminais de Autoatendimento (ATMs). Estes foram entendidos como objetos técnicos produzidos a partir de um circuito espacial de produção, que envolve desde a produção até a sua distribuição e consumo. Por esta razão, buscou-se acompanhar sua trajetória desde a produção propriamente dita - da qual fazem parte inúmeras indústrias - até a sua distribuição e consumo final - pelos bancos.

O entendimento do consumo dos ATMs foi fundamental na medida em que: a) foi justamente pela demanda dos bancos que cada indústria se organizou historicamente no Brasil, produzindo e dando novas formas e conteúdos, periodicamente, a estes objetos; b) o seu processo de "difusão" pelo território e as atuais localizações permitiram-nos reconhecer as diferentes situações dos lugares na complexa trama geográfica estabelecida pelas redes bancárias na formação socioespacial brasileira.

Além disso, ao serem consumidos pelos bancos comerciais, os ATMs passaram a ser incorporados ao meio geográfico, tornando-se um dos fixos que, por sua composição tecnológica, funcionalidade e pela capacidade de armazenamento e 
transmissão de informações, foram integrados aos sistemas técnicos bancários. Nesse sentido, esses objetos técnicos foram (e continuam sendo) constante e estrategicamente adquiridos e distribuídos pelos bancos no território de forma a suprir a busca pela oferta de determinados serviços financeiros e captação de recursos (via depósitos, por exemplo).

Tendo como referência a busca por uma coerência interna da argumentação e uma originalidade da abordagem para contribuir o máximo possível com a compreensão e o desenvolvimento de futuras pesquisas sobre o tema, a dissertação foi organizada em três capítulos. O primeiro capítulo buscou compreender transformações ocorridas de 1961 até 1991, envolvendo o início da automação bancária e a formação do circuito espacial de produção em território nacional. $\mathrm{O}$ segundo estabeleceu como início a abertura comercial e estendeu-se até 1999, quando houve a crise cambial e a compra da Procomp - maior empresa de informática e do circuito espacial de produção à época. Por fim, o terceiro capítulo, que teve como objetivo compreender as dinâmicas recentes do circuito espacial de produção, as diferenciações atuais nos círculos de cooperação e as transformações recentes do sistema bancário e da consolidação do uso de ATMs na formação socioespacial brasileira. 


\section{Automação bancária e a formação do circuito espacial de produção de ATMs no Brasil}

Nesse capítulo, buscou-se entender como ocorreram as primeiras iniciativas e processos ligados à automação bancária no país e como se relacionaram às dinâmicas do sistema bancário à época; como se deu a formação do circuito espacial de produção de ATMs; a importância do Estado e das políticas de substituição de importações no ramo de informática para esse processo; a importância da concentração bancária e das dinâmicas regionais para a formação desse circuito e para as dinâmicas urbanas brasileiras.

\subsection{Os primeiros fatores ligados à automação bancária no Brasil}

Ao longo da primeira metade do século XX, no Brasil, pode-se dizer que a divisão do trabalho bancário foi se consolidando no território nacional (CONTEL, 2006). A dificuldade na formação de um "corpo bancário no país capaz de prover crédito às atividades agrícolas e financiamentos hipotecários" (COSTA NETO, 2004, p. 22) motivou o governo federal, em 1905, a estatizar o Banco do Brasil, defini-lo como única instituição autorizada a emitir moeda em território nacional e, posteriormente, a regular o câmbio através de uma política nacional.

Uma rede de serviços bancários foi organizada e orientada para a busca de captação de recursos e pela necessidade de financiamento de certas atividades a partir da abertura de bancos públicos estaduais e de bancos privados em diversos pontos do território. Em paralelo com as iniciativas do Banco do Brasil (cuja sede estava então situada no Estado do Rio de Janeiro), ocorreu a abertura de uma série de bancos privados nos Estados de São Paulo, Minas Gerais e Espírito Santo.

Como apontou R. L. Correa (1989), ainda que São Paulo, Minas Gerais e principalmente Rio de Janeiro já despontassem com destaque em âmbito nacional, havia no país, em 1941, 512 sedes e 1.134 agências bancárias. Geralmente situadas em capitais político-administrativas e centros urbanos regionais, estes agentes beneficiavam-se das dinâmicas econômicas regionais, aproveitando-se do excedente 
econômico e do fortalecimento do intercâmbio em certas áreas para criar suas respectivas ofertas de serviços e ampliar suas respectivas áreas de atuação. Aproveitavam-se, igualmente, dos juros dos tomadores de empréstimos, para crescer e expandir suas respectivas áreas de influência, adquirindo outros bancos menores, capturando depósitos e expandindo a oferta de crédito.

Ao mesmo tempo, a ausência de uma instituição regulatória dificultava a atuação do Estado sobre o sistema financeiro e dava margens para um crescimento desordenado da atividade bancária. Tal situação começou a ser modificada em 1945, com a criação da Superintendência da Moeda e do Comércio (SUMOC) pelo governo federal. Esta instituição representou o início da regulação sistemática das atividades financeiras no país, na medida em que desencadeou diversas medidas voltadas para exercer um maior controle sobre a "macroeconomia" nacional. A partir de então passou a ser de responsabilidade desta Superintendência, entre inúmeras outras, representar o país junto a organismos internacionais, orientar a política cambial e supervisionar a atuação dos bancos comerciais (CONTEL, 2006).

Deve-se ressaltar que, embora houvesse um processo de alargamento dos contextos de atuação e de oferta de serviços financeiros, o sistema bancário não se adequava às necessidades existentes. Dentre as possíveis causas dessa situação, estão questões relativas à urbanização da população; esta tornou-se, cada vez mais, um fenômeno estruturante das dinâmicas nacionais: em 1940, 26,35\% da população era urbana, enquanto que, em 1960, passou a representar $45 \%$ do contingente (SANTOS, 1993).

São Paulo e Rio de Janeiro já se destacavam no quadro urbano nacional, sendo as únicas aglomerações com mais de um milhão de habitantes; ao mesmo tempo, emergiam cidades "intermediárias" como Santos, Campinas, Petrópolis e Jundiaí sob influência do progressivo desenvolvimento urbano-industrial das grandes aglomerações do Sudeste brasileiro. Não pode deixar de ser dito que as capitais estaduais eram importantes centros de suas respectivas regiões (GEIGER, 1963).

Sem dúvida, esse aumento e reorganização da população acabava por exercer certa "pressão" não apenas para financiamento de infraestruturas públicas, como também para oferta de serviços. Somava-se a esse quadro de demandas, a 
configuração do que J. M. Cardoso de Mello (1982, p. 89-90) denominou por "industrialização restringida" entre 1933 e 1955. Segundo a análise do autor,

a dinâmica da acumulação passa a se assentar na expansão industrial, ou melhor, porque existe um movimento endógeno de acumulação, em que se reproduzem, conjuntamente, a força de trabalho e parte crescente do capital constante industriais; mas a industrialização encontra-se restringida porque as bases técnicas e financeiras da acumulação são insuficientes para que se implante, num golpe, o núcleo fundamental da indústria de bens de produção, que permitiria à capacidade produtiva crescer adiante da demanda, autodeterminando o processo de desenvolvimento industrial (MELLO, 1982, p. 90)

Como explicou L. C. Dias (2005, p. 30), a expansão industrial do governo Juscelino Kubitschek "ajustou-se a um sistema financeiro no qual ainda prevaleciam formas de crédito e de financiamento herdadas do começo do século $\mathrm{XX}$, além de esbarrar num sistema de telecomunicações obsoleto e lacunar".

Pode-se pensar que a própria configuração do sistema bancário, ao final da década de 1950, podia ser uma das causas das referidas necessidades de acumulação, financiamento e suprimento de demandas em escala nacional. De um lado, havia uma relativa convergência entre localização das sedes e áreas de atuação (hinterlândia): "mais de $40 \%$ dos bancos atuavam apenas através de suas sedes, não possuindo nenhuma agência, quer na cidade-sede quer em sua hinterlândia" (CORREA, 1989, p. 21). De outro lado, já começava a se esboçar uma tendência para uma progressiva diminuição do número de sedes e aumento do número de agências, evidenciada pelo fato de, em 1961, existir uma proporção de 15,7 agências para cada sede, enquanto que, em 1941, a proporção era de 2,2 agências por sede (CORREA, 1989) ${ }^{3}$.

Tendo em vista a busca por novas formas de gestão e de difusão das informações dentro das redes bancárias que se constituíam e, igualmente, por um maior controle interno e por "promover a redução de custos operacionais do sistema financeiro e melhorar a qualidade dos produtos e serviços bancários"

\footnotetext{
${ }^{3}$ Nesse momento, segundo R. L. Correa (1989) os bancos públicos federais e estaduais, localizavam-se nas capitais político-administrativas (salvo algumas exceções). Já os privados, a localização relacionavase, sobretudo, ao grau de desenvolvimento das atividades econômicas regionais e à importância de certos centros urbanos regionais. Cabe ressaltar que, em 1961, a região Sudeste concentrava a maior parte dos bancos e dos centros de gestão bancária, ao mesmo tempo que poucos bancos possuíam uma atuação nacional, apenas o Banco do Brasil e o Banco da Lavoura de Minas Gerais S.A. No $2^{\circ}$ caso, o banco foi considerado pelo autor como o maior banco do privado do país em 1961.
} 
(PIRES, 1997, p. 4), diversos bancos passaram a impulsionar a automação de alguns processos internos (sobretudo de contabilidade financeira).

O ano de 1961 pode ser considerado um momento importante, pois foi nele que o Banco Bradesco comprou um grande computador da IBM para controlar o serviço de cobrança de títulos, conta corrente e atendimento ao cliente, aumentando enormemente sua eficiência na prestação desses tipos de serviços (Figura 1).

A partir daí, iniciou-se um processo de separação espacial das atividades interno aos bancos: 1) de um lado, havia uma máquina que imprimia cartões, em que ficavam registrados os saldos e operações de cobranças realizadas pelos clientes; e 2) de outro lado, os processos na chamada "retaguarda", isto é, onde ficava o computador estas eram processadas; ao fim do dia conferia-se as posições dos clientes de modo a garantir o controle das operações (VIANA, 2012).

Figura 1 - Primeiro computador pertencente ao Bradesco - IBM 1401 (1961)

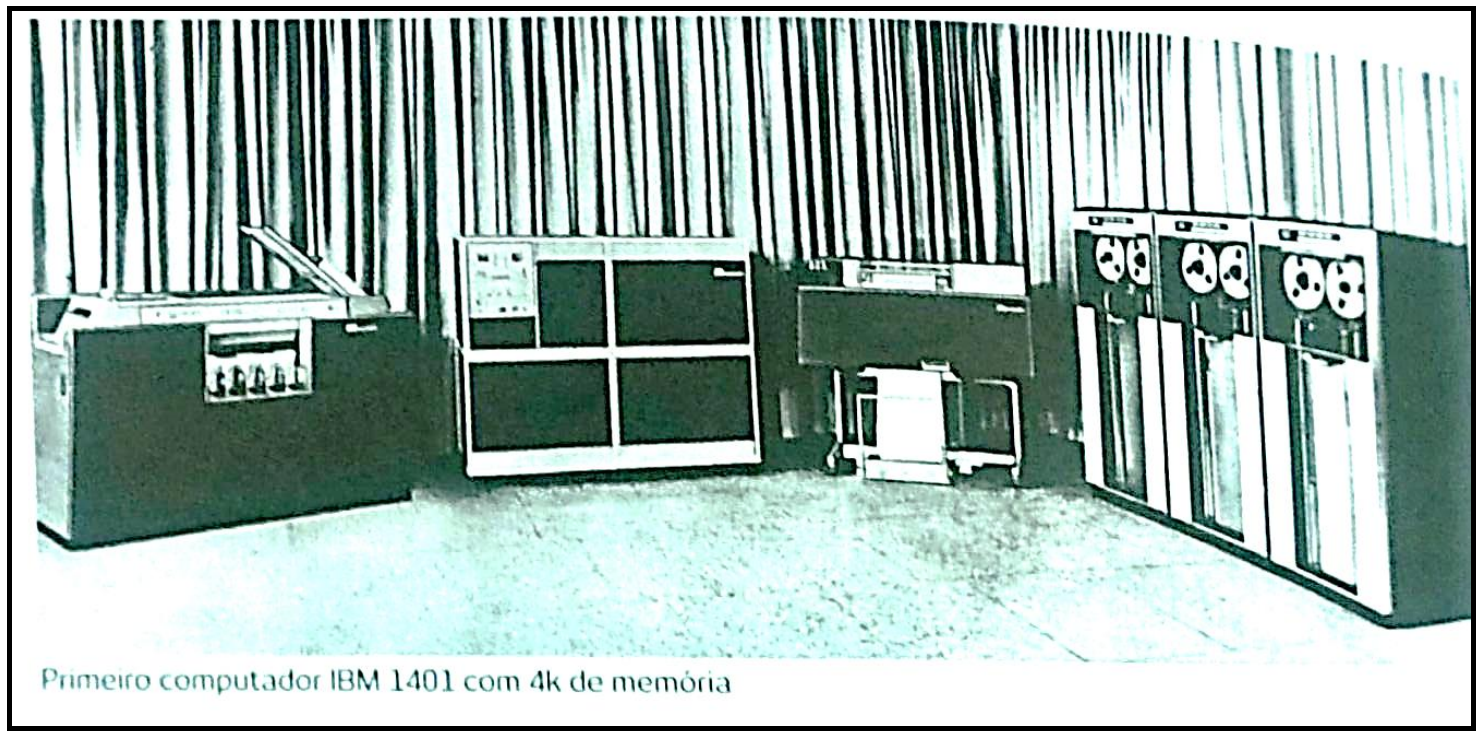

Fonte: Reproduzido de F. Viana (2012, p. 34).

No mesmo período, o Banco Nacional adquiriu (em 1962) da Burroughs o seu primeiro computador de grande porte. Em 1965 o Itaú comprou junto à IBM seu computador e o Bamerindus incorporou um computador da Univac em 1968.

Um dado importante desse momento é que a produção dos sistemas técnicos ligados à automação bancária era realizada por algumas poucas empresas estrangeiras, podendo ser destacadas as seguintes: Burroughs, IBM, Univac, NCR, 
Bull-Honeywell, Siemens-RCA. Os computadores de grande porte (também conhecidos como mainframes) foram a principal tecnologia adquirida por essas empresas naquele período (PIRES, 1997).

Entretanto, a presença de grandes empresas estrangeiras na produção de sistemas técnicos voltados para a automação - somada à baixa oferta de tecnologias específicas para o sistema bancário nacional - representavam ainda dificuldades para sua adoção sistematizada por parte dos bancos. Além desses fatores, os próprios entraves à expansão do sistema bancário que ainda existiam também limitavam sua implantação - devido, entre outros fatores, ao processo de integração física do território nacional (ainda incompleto à época) e ao caráter eminentemente regional dos bancos, que limitavam a oferta e abrangência geográfica dos serviços de cada instituição.

Com o objetivo de superar tais limitações teve início, no período pós-1964, um projeto de integração nacional fundado na busca pela modernização e reorganização produtiva do território, tendo nas finanças e nas telecomunicações elementos centrais desta reorganização. A criação do Conselho Monetário Nacional e do Banco Central - que assumiram o lugar da Superintendência da Moeda e do Crédito (SUMOC) - e, posteriormente, a criação da Empresa Brasileira de Telecomunicações e do Ministério das Comunicações foram medidas institucionais importantes nessa direção (DIAS, 1996; CONTEL, 2011).

Com as Reformas do Sistema Financeiro, de 1964 a 1965, passou-se a buscar, segundo L. Dias (2005, p. 33), instituir uma "via brasileira para a integração territorial", na qual a constituição de redes bancárias em escala nacional era um de seus projetos. Além disso, tentava-se criar uma estrutura financeira "nos moldes dos países avançados", difundindo instrumentos de mobilização financeira que teriam as seguintes funções principais:

a) resgatar a poupança e ampliar o crédito para todos os tipos de consumo; b) intermediar a transferência de capital de empréstimo; c) direcionar grandes massas aglutinadas de capital-dinheiro para agilizar projetos de grande porte, a longo prazo, para suportar o processo da acumulação do capital (CORDEIRO, p. 1).

Igualmente importantes para a busca de superação dos "estrangulamentos" existentes foram as diversas regulamentações voltadas para a abertura do sistema financeiro aos financiamentos externos. Conforme apresentado por A. Moura 
(1981), entre 1962 e 1967 foram criadas regulamentações que orientaram a abertura financeira para a captação de recursos externos, permitindo com que fossem abertas às empresas públicas e privadas, ainda em processo de integração territorial de seus respectivos mercados, uma série de linhas de financiamento.

Empréstimos poderiam ser tomados diretamente junto a instituições privadas estrangeiras, ou através da rede nacional de bancos comerciais, que também passaram a ser possibilitados para contratar financiamentos externos para capital fixo ou de giro desde que repassadas para firmas brasileiras (MOURA,1981).

Dessa maneira, algumas instituições puderam expandir as formas de obtenção de recursos e de oferta de créditos, fortalecendo-se ainda mais e permitindo o desenrolar de um intenso processo de fusões e aquisições. De forma a caracterizar os efeitos dessas primeiras medidas pode ser mencionada a redução do número de sedes bancárias para 145, entre 1961 e 1971, enquanto que o número de agências subiu para 5.247 (CORREA, 1989).

Um outro elemento importante desse subperíodo foram os eventos conhecidos como "Congressos dos Bancos", que reuniam uma vez por ano as instituições financeiras interessadas em discutir temas de interesse comum. O I Congresso foi realizado no Rio de Janeiro em 1960 que, segundo I. Ângelo (2007), foi fundamental para colocar os banqueiros em contato, fazendo com que eles se conhecessem; posteriormente, no II Congresso, de 1961 e realizado em Belo Horizonte, tornou-se possível a padronização da contabilidade bancária.

Com a formação das primeiras organizações de classe, como a criação, em 1965, da ADEVAL (Associação das Empresas de Distribuidoras de valores) e, em 1966, da FENABAN (Federação Nacional dos Bancos), passou a ser discutida a possibilidade de se criar uma "federação das associações" (ÂNGELO, 2007). Outro ponto importante que aumentou o interesse para a criação dessa federação mais robusta foram os "constantes desafios de interpretação e operação que atropelaram os bancos a partir da Lei da Reforma Bancária" (ÂNGELO, 2007, p. 11). Desse modo, em 1967 foi criada a FEBRABAN (Federação Brasileira das Associações de Bancos), durante o VI Congresso dos Bancos em Recife, para "representar os 
bancos no aspecto social, político e institucional e liderar a defesa dos seus interesses" (ÂNGELO, 2007, p. 14).

Nesse Congresso, além da criação da Federação mencionada, foram aprovadas duas iniciativas extremamente relevantes: a "escolha da linguagem eletrônica dos bancos" e "a dimensão padronizada do cheque, que está em vigor até hoje, sem nenhuma mudança" (ÂNGELO, 2007, p. 14).

O depoimento do presidente do Itaú à época (R. Setúbal), reproduzido por I. Ângelo (2007, p. 14) é, aliás, muito representativo da busca, nesse início, para que os processos de automação tivessem um padrão mais unificado no território:

Eu tinha levantado a tese de que não devíamos cometer o mesmo erro das estradas de ferro, que tem não se quantas bitolas no Brasil, um tumulto completo. Já tinha banco com o sistema americano, havia bancos com o sistema europeu, e eu levei uma proposta para adotar o sistema de marcação eletrônica europeia, que é a que está em vigor até hoje. A padronização do cheque ia permitir a compensação mais rápida e em melhores condições.

Assim, os bancos começaram a se organizar e se articular tanto para discutir temas e preocupações comuns, como para unificar e representar os seus interesses corporativos junto a instituições nacionais e internacionais no processo de implementação de novas regulações públicas, o que acabou dando ainda mais força para a sua atuação na formação socioespacial brasileira.

A presença de grandes empresas estrangeiras na produção de objetos e sistemas técnicos voltados para a automação, somada à baixa oferta de tecnologias específicas para o sistema bancário nacional, representavam ainda dificuldades para a adoção sistematizada por parte dos bancos. Mesmo assim, o Bradesco continuou investindo na expansão do processamento da contabilidade financeira, possuindo, em 1968, oito computadores, que permitiu ao banco formar um primeiro "embrião" do que viria a ser depois o seu Centro de Processamento de Dados (CPD). Em 1973, fruto de tais investimentos o banco já processava informações contábeis de 500 agências, com a formação de seus centros regionais em Curitiba e Rio de Janeiro.

Nesse momento, esse banco também comprou algumas máquinas dispensadoras de dinheiro que ficaram conhecidas como "\$O Bradesco", seguindo o que havia feito o Itaú no ano de 1970, comprando esse objeto técnico, o qual 
denominou "Itaúchek". Esse banco também investiu na automação de suas agências durante a década de 1960 e início da década de 1970 (Figura 3 - Detalhe do terminal e do cartão utilizado pelo Banco Itaú para saque).

Como relatado por G. Dib (2010), esses objetos técnicos foram comprados junto à empresa Chubb (a mesma que introduziu o primeiro terminal em um banco da Inglaterra em 1967) e eram acionados por cartões perfurados (como pode ser visto nas figuras 2 e 3 ):

A gente chegava a uma dessas caixas, botava o cartãozinho, digitava uma senha, o cartãozinho ficava retido e ela pagava um valor fixo. E você tinha de buscar o cartão na agência no dia seguinte. Assim operavam os 'caixas automáticos' em 1970. (DIB, 2010, p. 48).

Figura 2 - Primeiras máquinas dispensadoras de dinheiro e cartão utilizado para saques pelo Bradesco
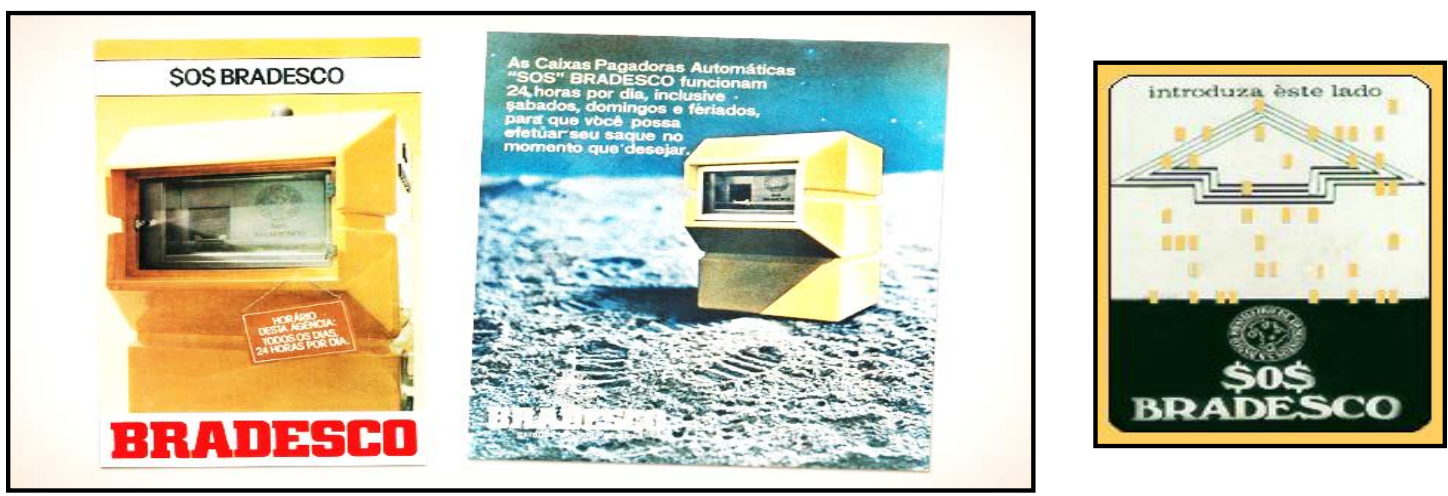

Fonte: Reproduzido de F. Viana (2012, p. 34).

Figura 3 - Detalhe do terminal e do cartão utilizado pelo Banco Itaú para saque
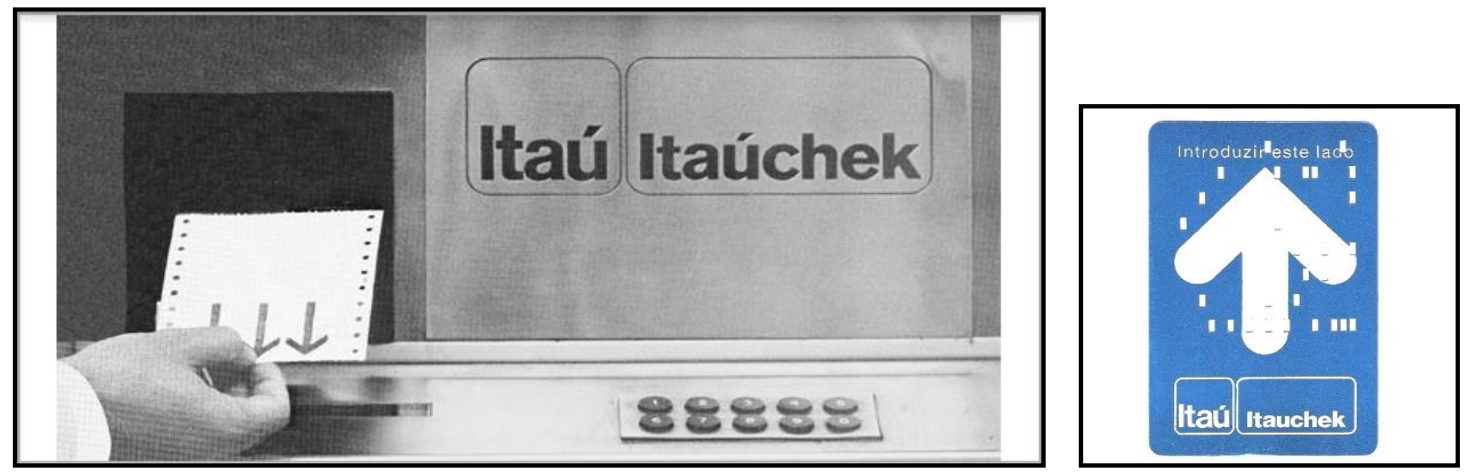

Fonte: Sítio eletrônico da instituição ${ }^{4}$.

4 Disponível em: https://www.itau.com.br/sobre/memoria/conheca-o-itauchek-avo-dos-caixaseletronicos.html. É possível observar o funcionamento do equipamento no comercial veiculado em TVs na década de 1970, cujo vídeo está disponível em: https://www.youtube.com/watch?v=knR0U7FflQk. 
Esses foram os primeiros terminais de autoatendimento, que, ao contrário dos terminais atuais, não eram interligados de forma direta aos sistemas técnicos dos bancos e que, por essa razão, não atualizavam os saldos instantaneamente e tampouco permitiam flexibilidade para saques: o dinheiro era disponibilizado em quantidades fixas, envolto em uma pequena bolsa plástica.

\subsection{As empresas nacionais e a difusão da automação bancária}

Nesse momento, por meio do I e do II Plano Nacional de Desenvolvimento iniciou-se um intenso esforço de articulação territorial, com projetos estatais de utilização de recursos naturais (água, terra e minérios) e industriais de larga envergadura (construção de hidrelétricas, indústrias de materiais não-ferrosos, químicas e petroquímicas), sendo implantados também nas áreas mais "periféricas" do país, isto é, naquelas com um desenvolvimento regional proporcionalmente inferior às áreas dinâmicas (Sudeste e Sul). Esses projetos, além de contribuir para consolidar a matriz industrial existente no Brasil, favoreceu, ao longo do tempo, sua ampliação e a desconcentração, que, junto do crescimento da produção em São Paulo, beneficiou a articulação desse estado com os demais (CANO, 1998).

Conforme destacou C. A. Pacheco (1998), houve uma diferenciação interna entre o subperíodo situado de 1971 a 1977 e o situado após 1977. Inicialmente (1971-1977), os investimentos estatais e industriais concentraram-se "no Sudeste, embora com proporção menor em São Paulo" e representaram "ganhos" para “ Minas Gerais, Bahia, Rio Grande do Sul e os demais estados do Centro-Sul"; para esse autor, os investimentos setoriais teriam um papel central na explicação, na medida em que houve uma setorialização do desenvolvimento industriais, com os "setores de bens de capital e produtos metálicos e não-metálicos (...) [tendo] forte concentração espacial, enquanto a petroquímica, os bens de consumo e a automobilística estariam menos concentrados, favorecendo o Sul e a Bahia." (PACHECO, 1998, p. 66) ${ }^{5}$. Nesse momento, conforme análise do autor, houve a formação no Nordeste do país do polo petroquímico na Bahia, em Aracaju e em Maceió, do complexo metal-mecânico-elétrico, da indústria têxtil e de calçados; e

\footnotetext{
${ }^{5}$ Caberia perguntar, todavia, se foi a concepção setorial que levou a um desenvolvimento regional desconcentrado, ou se foi, justamente, as desigualdades regionais existentes que levaram o projeto ser pensado de forma a potencializar os investimentos por meio de uma concepção setorializada.
} 
na Amazônia houve a consolidação da Zona Franca de Manaus - que havia sido instituída em 1967.

Já o período após-1977 foi marcado, de fato, por uma desconcentração dos investimentos, por conta da medida 14 do Conselho de Desenvolvimento Industrial (CDI) que instituiu a preferência de investimentos nas indústrias do Rio de Janeiro, Minas Gerais, do Sul, Nordeste e dos complexos agroindustriais do Norte e CentroOeste (PACHECO, 1998). Essas inversões foram um fator decisivo na "modificação espacial da indústria", que ocorreu nesse subperíodo, sendo em grande parte

um resultado da estratégia do II PND, que previa implantar projetos como: ferro e bauxita no Pará; cobre na Bahia; fosfato em Minas Gerais; potássio em Sergipe; petróleo e gás natural nas plataformas nordestinas e fluminense; carvão e pirita em Santa Catarina e no Rio Grande do Sul; sal no Nordeste; siderurgia no Maranhão, no Espírito Santo e em Minas Gerais; cloroquímica em Alagoas e Sergipe; papel e celulose e cimento no Nordeste e no Espírito Santo; e diversas hidrelétricas como Itaipu, Paulo Afonso IV, Xingó e Tucuruí (PACHECO, 1998, p. 69).

Assim, a situação de domínio de empresas estrangeiras no mercado nacional de automação bancária, que prevaleceu até primeira a metade da década de 1970 no Brasil, levou em 1974 a importação de computadores atingir a cifra de US\$ 98 milhões, ocupando o terceiro lugar dentre os produtos manufaturados (TIGRE, 1985), aumento este favorecido pelo crescimento acelerado do país e pela busca de modernizar "amplos segmentos da administração pública e do setor privado", com ampliação da base instalada de computadores de 506 para 3.843 unidades (ACCORSI, 1990, p. 26). Porém, com II PND, o governo passou a atuar ativamente também no processo de desenvolvimento tecnológico das indústrias nacionais.

O excerto do referido plano, apresentado a seguir, é representativo do posicionamento governamental em torno da questão:

será continuado o esforço de expansão da produção de equipamentos eletrônicos e, principalmente, de computadores comerciais de grande porte, (...) ao mesmo tempo, será implantada a indústria e transferida a tecnologia, no campo da eletrônica digital [o que] se fará pela implantação da indústria brasileira de minicomputadores, sob controle do capital nacional, pela fabricação de processadores de centrais eletrônicas de comutação, na área de telecomunicações, e pela implantação de sólida indústria nacional de componentes eletrônicos sofisticados, como os circuitos integrados (II PND, 1974, p. 30) 
Nesse sentido, a criação da empresa Cobra (Computadores e Sistemas Brasileiros Ltda.), em 1974, foi um importante marco para a realização de tais metas; ao mesmo tempo, também favoreceu a criação de um circuito espacial de produção de objetos técnicos para automação em bases nacionais. Sua composição acionária foi dividida entre a empresa privada nacional Equipamentos Eletrônicos, a holding estatal Digibrás e a empresa privada inglesa Ferranti Ltda.

Entretanto, não foi possível manter a composição inicial e conforme A. Accorsi (1990, p. 28):

A insuficiência de capital da empresa para o desenvolvimento e a fabricação de computadores nacionais ficou patente desde o início. Após três anos de prejuízos sucessivos passou a prevalecer a exclusividade do capital nacional, dividido entre várias agências estatais e um pool de onze bancos privados.

Nessa situação de impulsos estatais, foram estabelecidas, a partir de 1975, restrições à importação de computadores, impulsionando produtores nacionais a investirem no setor (ACCORSI, 1990; CERNEV, DINIZ \& JAYO, 2009). Como pode ser visto no quadro a seguir (Quadro 2Quadro 2), diversas empresas privadas nacionais acabaram sendo estimuladas a se formarem subsequentemente, como foram os casos da Moddata fundada em 1976, da Digirede e da Edisa, constituídas em 1977.

Os bancos nacionais também investiram em empresas privadas próprias, para a produção de tecnologias voltadas para a automação bancária. Em 1978, o Bradesco - junto com a Sharp - ajudou a fundar a SID Informática S/A e, em 1979, o mesmo banco participou da fundação da empresa Laboratórios Digital S/A. Ainda nesse ano, o Itaú fundou a Itautec Informática. Por fim, a Procomp foi fundada em 1985.

Entretanto, vale ressaltar que as limitações impostas às importações restringiram a participação de empresas estrangeiras na produção de minicomputadores, mas as mesmas continuaram sua atuação em território nacional em diversos segmentos, inclusive de computadores de médio e grande portes; este foi o caso da IBM, da Telematic e da Borroughs. A própria IBM estabeleceu parcerias com várias destas empresas nacionais supracitadas para produção de equipamentos diversos (impressoras, fitas magnéticas, entre outros). 
Quadro 2 - Principais empresas voltadas para produção de objetos técnicos para automação bancária instaladas no Brasil nas décadas de 1970 e 1980

\begin{tabular}{|c|c|c|c|}
\hline Empresa & $\begin{array}{l}\text { Ano de } \\
\text { Fundação }\end{array}$ & $\begin{array}{l}\text { Localização } \\
\text { (sede) }\end{array}$ & Principais produtos \\
\hline Cobra & 1974 & $\begin{array}{l}\text { Rio de } \\
\text { Janeiro }\end{array}$ & $\begin{array}{l}\text { Minicomputadores, Automatic Teller Machines } \\
\text { (ATMs), Terminais de transferências de fundos, } \\
\text { entre outros. }\end{array}$ \\
\hline Moddata & 1976 & $\begin{array}{l}\text { Rio de } \\
\text { Janeiro }\end{array}$ & $\begin{array}{l}\text { Equipamentos de comunicação (modens, centrais } \\
\text { de comutação telefônica) para uso e gerenciamento } \\
\text { interativo de banco de dados entre agências. }\end{array}$ \\
\hline Digirede & 1977 & Diadema & $\begin{array}{l}\text { Sistemas de automação, sistema de transferência } \\
\text { de fundos, sistema automático de resposta audível, } \\
\text { concentrador de terminais de videotexto, sistemas } \\
\text { multiusuários. }\end{array}$ \\
\hline Edisa & 1977 & $\begin{array}{l}\text { Barueri/ } \\
\text { Campinas }\end{array}$ & $\begin{array}{l}\text { Produzir, a partir de importação de tecnologia, } \\
\text { impressoras, terminais de caixa bancário, terminal } \\
\text { de consulta bancário, vídeos de sistemas bancários. }\end{array}$ \\
\hline SID & 1978 & Curitiba & $\begin{array}{l}\text { Minicomputadores, Terminais de Transferências } \\
\text { de fundos, Automatic Teller Machines (ATMs), entre } \\
\text { outros. }\end{array}$ \\
\hline Digilab & 1979 & São Paulo & $\begin{array}{l}\text { Impressoras de Grande Porte, terminais de caixa, } \\
\text { terminais de extrato, terminais de dispensadores de } \\
\text { dinheiro, terminais de vídeo, interface de } \\
\text { comunicação, servidores de disco e winchester, } \\
\text { equipamentos de proteção de transmissão. }\end{array}$ \\
\hline Itautec & 1979 & São Paulo & $\begin{array}{l}\text { Equipamentos para automação bancária, } \\
\text { comercial e industrial, comunicação de dados, } \\
\text { software e microcomputação; circuitos integrados, } \\
\text { semicondutores e Banco Eletrônico. }\end{array}$ \\
\hline Conpart & 1980 & $\begin{array}{l}\text { Rio de } \\
\text { Janeiro }\end{array}$ & Sem informações \\
\hline Procomp & 1985 & São Paulo & $\begin{array}{l}\text { Automatic Teller Machines (ATMs), Terminais de } \\
\text { Transferências de fundos, processadores front-end, } \\
\text { processadores risc, computadores e CPUs. }\end{array}$ \\
\hline Tecban & 1989 & Barueri & $\begin{array}{l}\text { Automatic Teller Machines (ATMs) e Banco } \\
\text { Eletrônico }\end{array}$ \\
\hline
\end{tabular}

Fonte: Elaboração do autor com base em H. Pires (1995) e de consulta na internet junto aos sites de empresas citadas.

Um processo marcante que favoreceu a convergência entre bancos e circuito espacial de produção diz respeito aos "ganhos de escala" possibilitados pela concentração bancária e pelos lucros inflacionários praticados com o floating. 
Segundo N. Cavalheiro (1982) houve a redução de 219 bancos no país entre 1964 e 1976. Para este autor, isso pode ser interpretado como um dado evidente da crescente concentração setorial, na medida em que a absorção de bancos pequenos e médios por bancos maiores foi a forma mais comum de expansão das redes privadas nacionais ${ }^{6}$, muito embora os estabelecimentos públicos e estrangeiros tenham expandido suas topologias mediante fatores internos de crescimento sobretudo investimentos em expansão de agências.

Foi neste contexto que as cidades da Região Sudeste abrigaram a maior parte destas empresas, cujos principais fatores de localização estavam associados a uma maior densidade das infraestruturas de telecomunicações (DIAS, 1996), presença de economias externas favoráveis e a centralização da função de gestão da atividade bancária (CORREA, 1989).

A reestruturação do sistema financeiro, com o apoio das telecomunicações, permitiu uma maior rapidez na transmissão de informações, o que possibilitou aos bancos "recolher a poupança, a difundir e a facilitar o crédito, expandindo o consumo de massa" (CORDEIRO, 1992. p. 06). Ao mesmo tempo, forneceu as bases para um comando mais centralizado e para o prosseguimento dos investimentos em automação bancária, reforçando ainda mais a posição de São Paulo na rede urbana brasileira (CONTEL, 2007).

Neste contexto, pode-se dizer que os serviços avançados e a indústria de alta tecnologia passaram a ser estrategicamente dominantes no país. Tal processo foi causa e efeito de um novo padrão de localização espacial, caracterizados pela simultaneidade de sua concentração e dispersão, na qual a inter-relação entre os diferentes espaços passou a ocorrer por meio de uma complexa e hierarquizada rede de fluxos. A crescente convergência entre os centros de gestão bancários e circuito espacial de produção de tecnologias bancárias foi, igualmente, um dos elementos fundamentais para que Região Metropolitana de São Paulo se consolidasse como "lócus privilegiado da gestão do capital e do trabalho imaterial" no país (LENCIONI, 2000, p. 474).

\footnotetext{
6 "É de se fixar que nem todos esses 219 bancos foram absorvidos pelos bancos sobreviventes, visto que muitas vezes um banco absorvia outros em seu processo de crescimento, mas em determinado ano era absorvido por um outro banco maior, este sim sobrevivente" (CAVALHEIRO,1982, p. 46 e 47).
} 


\title{
1.3. Os círculos de cooperação: a confluência entre indústria de alta tecnologia e bancos nacionais 'sob marcha forçada'
}

Conforme mencionado, em meio a um conjunto de estímulos governamentais para a substituição de importações e para a concentração bancária, foi possível uma convergência entre sistema bancário e circuito espacial de produção de tecnologias bancárias.

Compreender como são estabelecidos os "laços" entre empresas e entre estas e outras instituições - os círculos de cooperação - é de fundamental importância para que se possa estudar a forma com que o território passa a ser diferenciado a partir de uma dissociação geográfica das atividades. Como asseverou F. Grimm (2002, p. 8), do ponto de vista operacional, os círculos de cooperação

\begin{abstract}
podem surgir quando uma empresa desinteressada pela distribuição de seu produto em determinada área (dificuldade de acesso, a inviabilidade em custo-benefício) delega essa tarefa a uma outra empresa. Já no que tange aos aspectos políticos, o papel das normas, da regulação (pública e privada), das finanças, de associações e fusões pode definir e redefinir os círculos de cooperação, podendo até, por conseguinte, alterar circuitos espaciais de produção já existentes (o número de fábricas, sua localização, a quantidade de funcionários, entre outros).
\end{abstract}

Nesse sentido, trata-se de agentes diversos que, ao se inter-relacionarem a partir de seus objetivos e perspectivas, formam "círculos de cooperação cada vez mais intensos e extensos" (CASTILLO \& FREDERICO, p. 465); deve-se ressaltar ainda que: "dentro dos circuitos espaciais produtivos, são estabelecidos diversos círculos de cooperação: entre empresas; entre empresas e poderes públicos locais, regionais e nacionais; entre empresas, associações, instituições etc." (CASTILLO \& FREDERICO, 2010, p. 465)

Dessa forma, pode-se dizer que o processo de formação dos círculos de cooperação dentro do circuito espacial de produção de tecnologias bancárias não se restringe apenas aos agentes diretamente ligados à automação, muito embora, em muitos casos, os próprios bancos formaram uma de suas partes fundamentais. Envolve, certamente, uma conjuntura mais ampla em que empresas, instituições e políticas governamentais foram progressivamente emergindo e consolidando relações, ganhando ainda mais força com o II PND e a reserva de mercado.

O início desse processo, na década de 1960, remonta aos cursos de graduação em engenharia eletrônica e das pesquisas pioneiras em importantes 
Universidades brasileiras. Este foi o caso do Instituto de Tecnologia Aeronáutica (ITA), que, em 1961, desenvolveu o primeiro computador digital no Brasil.

Em posição de igual destaque figuraram as pesquisas na área de engenharia eletrônica, ao longo de toda a década de 1960. Na Escola Politécnica da Universidade de São Paulo (POLI/USP), na Pontifícia Universidade Católica do Rio de Janeiro (PUC-RJ) e na Coordenação dos Programas de Pós-Graduação em Engenharia da Universidade Federal do Rio de Janeiro (COOPE/UFRJ) (EVANS, 1986). Como ressaltou V. Dantas (1988), essas instituições foram responsáveis pela concepção e execução, no país, dos primeiros projetos de transistores, circuitos integrados e programas de processamento de dados.

Outro ponto importante foi a implementação do Plano Estratégico de Desenvolvimento de 1967, que criou a Financiadora de Estudos e Projetos (Finep), o Fundo Nacional de Desenvolvimento Científico e Tecnológico (FNDCT) e a transformação do $\mathrm{CNPq}$ para fundação responsável por coordenar a política de desenvolvimento científico e tecnológico nacional. Estes órgãos públicos exerceram um importante papel no financiamento de empresas de engenharia, pesquisas universitárias e direcionamento dos recursos governamentais "para favorecer o ingresso das empresas nacionais nos setores considerados estratégicos da economia" (DANTAS, 1988, p. 26).

Nesse momento, paralelamente às pesquisas universitárias, começou a ser formado um primeiro mercado de usuários de computadores em setores públicos e privados. A criação Sucesu - Sociedade de Usuários de Computadores e Equipamentos Subsidiários -, no ano de 1967, representou um significativo avanço na institucionalização das demandas dos agentes desse mercado com o objetivo "para trocar ideias e experiências entre si e promover a defesa de seus interesses frente aos fornecedores" (DANTAS, 1988, p. 30); acerca desta sociedade destacamse os Congressos organizados em São Paulo e no Rio de Janeiro que contribuíram enormemente para essas trocas.

P. Evans (1986, p. 16), por sua vez, destacou a importância das seguintes iniciativas e demandas estatais que serviam de "alicerce para a promoção de uma nova política" na área de informática: 
- A existência de uma "infraestrutura organizacional" no Banco Nacional de Desenvolvimento (BNDE) favorável a uma política de informática; tratava-se de um "grupo de nacionaisdesenvolvimentistas" voltados para "promoção de uma estrutura industrial nacional mais diversificada e integrada verticalmente" (EVANS, 1988, p. 16);

- As necessidades da Secretaria de Processamento de Dados (SERPRO), ligada ao Ministério da Fazenda, que não eram supridas pelos equipamentos existentes - fornecidos por empresas estrangeiras. Nesse local, passou-se a desenvolver parte de seus próprios hardwares por meio da modificação e adaptação; também se adquiriu experiência em processamento de dados e consciência "das desvantagens de depender de fornecedores distantes" (EVANS, 1986, p. 16);

- Havia, por fim, "a modernização do equipamento militar brasileiro", sobretudo na Marinha; essa iniciativa criava uma "apreensão" com relação "à dependência de tecnologia estrangeira sobre a qual o Brasil não tinha um controle industrial". Essa situação contribuiu para que, internamente, começasse a se desenvolver um quadro próprio de técnicos de processamento de dados e uma "solidarização" aos "argumentos a favor de uma indústria nacional de computadores" (EVANS, 1986, p. 16).

Assim, as discussões e as estratégias para o ramo de informática foram se aprofundando até que, no ano de 1971, foi criado o Grupo de Trabalho Especial (GTE) para a construção de um protótipo de computador, com financiamento do FUNTEC (Fundo Nacional de Tecnologia, do BNDE) e do FNDCT, ligado à época ao CNPq. O projeto foi incumbido ao Laboratório de Sistemas Digitais da POLI/USP, enquanto o GTE estava instalado em um dos prédios da Marinha, coordenando as atividades no centro do Rio de Janeiro (DANTAS, 1988). Após a conclusão do projeto, em 1972, esse Laboratório assinou contrato com a Marinha para implantação de um computador em uma de suas fragatas; nesse projeto participaram também a PUC-RJ e o COOPE/UFRJ, em meio a um intercâmbio de práticas e ideias. 
Esse contexto político-institucional, favorável ao transbordamento de conhecimentos e práticas (no ramo de informática) para fora da Universidade, também permitiu a formação do Instituto Brasileiro de Informática junto ao IBGE/RJ, em 1972, com participação do Departamento de Informática da PUC/RJ. Neste Instituto passaram a ser processados de forma inovadora os dados do Censo de 1970, cujos resultados saíram no prazo de três anos, ao contrário dos anteriores que levavam cerca de dez anos para serem divulgados (DANTAS, 1988).

O que vale destacar dos eventos relatados anteriormente é sua capacidade de solidarizar lugares e agentes, permitindo a compreensão da extensão dos círculos de cooperação até então existentes: o eixo São Paulo-Rio de Janeiro e a presença pontual de Brasília por meio da Serpro, ligada ao Ministério da Fazenda. O foco no desenvolvimento do ramo da informática, como uma política de Estado, com participações diretas e decisivas de Universidades é, igualmente, um dos pontos mais marcantes desses círculos.

Todavia, estas iniciativas acabavam "ligadas" aos circuitos espaciais de produção de empresas estrangeiras, dada a pouca expressividade das empresas nacionais. Conforme relatou V. Dantas (1988), dos 600 computadores existentes em 1971 no país, 75\% eram da IBM, 20\% da Borroughs e 5\% de outros fabricantes.

Buscando reverter essa situação, em que os custos das importações e os saldos da balança comercial eram fatores negativos a serem superados, formou-se a Coordenação de Processamento Eletrônico (Capre), em 1972; a partir de 1975, com a ampliação de suas atribuições, passou também a estabelecer inúmeras restrições à importação de diversos equipamentos no mercado de computadores de pequeno porte $^{7}$ (HELENA, 1980; ACCORSI, 1990).

Como foi visto no subitem anterior, a partir das políticas de cunho protecionista, uma série de empresas nacionais puderam se formar e estabelecer um processo de substituição de importações no ramo. A criação da Secretaria Especial de Informática (SEI), que assumiu o lugar da Capre, em 1979, foi um importante passo na institucionalização e na ampliação dos instrumentos políticos para a

\footnotetext{
7 “Ao restringir as importações em 1975, em razão das dificuldades do balanço de pagamentos, o governo tomou medidas generalizadas como: a) obrigatoriedade de depósito prévio no Banco Central, (feito pelo importador) no valor das importações; b) no caso de máquinas e equipamentos, passou a exigir que fossem financiados pelo fornecedor ou por instituições estrangeiras para pagamento em, no mínimo, 5 anos, como forma de evitar a evasão imediata de divisas" (HELENA, 1980, p. 87).
} 
reserva de mercado, tais como os controles às importações, às concessões de licenças de fabricação para empresas e supervisão da demanda dos órgãos públicos e empresas estatais (ACCORSI, 1990).

Igualmente importantes foram os investimentos estatais para a criação do CPqD (Centro de Pesquisa e Desenvolvimento), em 1976, e do CTI (Centro Tecnológico para Informática), em 1982, ambos ligados à Telebrás e sediados na cidade de Campinas. Estes centros fomentaram pesquisas as indústrias emergentes de tecnologias em telecomunicações, responsáveis por abastecer os mercados incluindo as redes bancárias - de centrais de PABX, centrais de comutação eletromagnética, centrais de comutação eletrônica, aparelhos telefônicos, entre outros (LEE, 2003).

Estas políticas tiveram resultados concretos para todo o circuito espacial de produção. Segundo A. Accorsi (1990, p. 28), os mercados deste circuito expandiram-se e passaram a se diferenciar da seguinte maneira:

Quadro 3- Diferenciação do parque instalado de computadores no Brasil

\begin{tabular}{|c|c|}
\hline Nicho de Mercado & Ritmo de expansão \\
\hline $\begin{array}{l}\text { Micro e } \\
\text { Minicomputadores }\end{array}$ & $\begin{array}{l}\text { "expandiu-se a taxas médias da ordem de } 53 \% \text { ao ano, em termos de valor, } \\
\text { entre } 1973 \text { e } 1982 \text {. A base instalada quadruplicou entre } 1980 \text { e } 1982 \text {, sendo } \\
\text { formada, quase em sua totalidade por empresas nacionais" }\end{array}$ \\
\hline $\begin{array}{l}\text { Computadores } \\
\text { Médios }\end{array}$ & $\begin{array}{l}\text { "constituídos principalmente por sistemas importados, expandiu-se a taxas } \\
\text { médias de } 10 \% \text { ao ano entre } 1973 \text { e } 1982 \text { " }\end{array}$ \\
\hline $\begin{array}{l}\text { Computadores de } \\
\text { Grande Porte }\end{array}$ & $\begin{array}{l}\text { "produzidos localmente pela IBM, Borroughs e Telematic, [o valor dos } \\
\text { computadores] aumentaram a uma taxa média de } 26 \% \text { ao ano, entre } 1973 \text { e } \\
\text { 1984. No período compreendido entre } 1980 \text { e } 1982 \text { a expansão atingiu } 84 \% \\
\text { em valor" }\end{array}$ \\
\hline
\end{tabular}

Fonte: Elaboração própria, com base em A. Accorsi (1990, p. 28).

Em 1981, o setor financeiro concentrava $27 \%$ da base instalada de computadores, sendo que, do total, 93\% concentrava-se em bancos comerciais (ACCORSI, 1990). E, no que tange ao circuito espacial de produção de tecnologias bancárias, M. Dantas (1989, p. 88) foi ainda mais enfático:

Além dos computadores de uso geral, contamos [em 1986] com 7,4 mil UCPs concentradoras de operações bancárias, 106,3 mil terminais bancários, 800 ATMs (os quiosques que nos socorrem quando falta dinheiro no fim de semana), mais de 
350 caixas-pagadoras. São mais de 155 mil modems, 10 mil terminais de vídeotexto, 1,5 mil controladoras de comunicação (das quais 780 tecnologias Itautec e 627 tecnologias IBM), além de terminais de telex, PABXs, CPAs e outros equipamentos de telecomunicação e de transmissão de dados.

A progressiva nacionalização da produção permitiu empregar 42 mil trabalhadores no circuito da informática como um todo, sendo que desse total 50\% possuíam ensino médio e de 25 a 30\% eram técnicos de nível superior (DANTAS, 1989).

Assim, pode-se dizer que durante esse período, sob os auspícios de uma política militar, o sistema bancário aproveitou-se dessa expansão do circuito espacial de produção e da extensão de seus círculos de cooperação na formação socioespacial brasileira para impulsionar tanto seus investimentos em equipamentos e processos de automação bancária, como, igualmente, expandir o seu controle sobre o desenvolvimento tecnológico, comprando e tornando-se acionista das indústrias nascentes no país. O Estado, atuando como um agente central e catalisador desse processo, favoreceu, nesse sentido, a confluência entre indústria de alta tecnologia e bancos comerciais.

\subsection{Os ATMs e as possibilidades de circulação da informação bancária nos anos 1980}

De modo geral, pode-se afirmar que a circulação da informação bancária se relacionou historicamente com três elementos fundamentais: as condições para a integração informacional do território, o arcabouço político-normativo de regulação dos fluxos e das atividades financeiras e a constituição de uma rede de cidades funcionalmente integradas às dinâmicas internas e externas ao país. Esses processos deram-se em uma formação socioespacial diferenciada regionalmente pelas dinâmicas específicas da agricultura, indústria, comércio e concentração do poder político.

Amplamente beneficiado pela sua função política, o Rio de Janeiro foi, durante certo período, a mais importante metrópole nacional. Porém, conforme análise de M. Santos e M. L. Silveira (2001), a unificação dos mercados e a construção de uma rede de estradas foram coetâneos à metropolização e à formação de núcleos urbanos no interior do país: 
É num Brasil integrado pelos transportes e pelas necessidades advindas da industrialização que vão nascer importantes cidades no interior. Estas decorrem do crescimento populacional, da elevação dos níveis de vida e da demanda por serviços urbanos em número e frequência maiores que anteriormente (SANTOS \& SILVEIRA, 2001, p. 44).

A expansão dos transportes terrestres, com progressiva dominância das rodovias, o dinamismo de seu parque industrial e os movimentos migratórios da população favoreceram a situação de primazia de São Paulo na rede urbana brasileira e o progressivo enfraquecimento do Rio de Janeiro. Ao mesmo tempo, a construção de Brasília reforçou as tendências expostas anteriormente e tornou mais complexa as respectivas áreas de influência sobre conjunto de cidades existentes (SANTOS \& SILVEIRA, 2001).

Os sucessivos governos militares - iniciados com o golpe de 1964 e terminados na redemocratização do país, em 1985 - representaram, em grande parte de suas ações, uma continuidade de tais políticas de integração nacional e desenvolvimento regional de cunho nacional-desenvolvimentistas. Como caracterizaram B. Becker e C. Egler (1994, p. 136), o regime militar "abrange um período bastante complexo: a crise dos anos sessenta, o 'milagre' entre 1968 e 1972, até as vésperas da recessão que caracteriza os primeiros anos da década de 80".

Em tais contextos situou-se um Estado autoritário e centralizador, responsável por sustentar "níveis elevados de investimento com grandes gastos governamentais e intervenção direta no aparato produtivo da economia, às custas do endividamento com o sistema bancário nacional e internacional" (BECKER \& EGLER, 1994, p. 136). Foi esse tipo de Estado que exerceu "seu programa para a modernização" baseado em um "projeto territorial fundado no ideário da integração nacional e do Brasil potência" (BECKER \& EGLER, 1994, p. 136). Esse projeto territorial sustentou-se por meio de planos, ações e inciativas diversas e tiveram como fundamento,

uma ação rápida e combinada para, simultaneamente completar a ocupação do território, incorporando o centro-oeste e a 'ilha' amazônica; modernizar e expandir a economia nacional articulando-a à internacional; estender o controle do Estado a todas as atividades e a todos os lugares. Estas políticas tiveram também a função de legitimação do Estado. (BECKER \& EGLER, 1994, p. 144)

Um dos seus mais importantes pilares foi a continuidade das políticas de integração do território nacional. Nesse aspecto, destacam-se: 1) a ampliação do 
modelo de integração material fundado no modal rodoviário; 2) as iniciativas ligadas à estruturação da integração informacional, fundada na expansão da malha de transmissão de energia elétrica e do sistema nacional de telecomunicações.

Outro pilar desse projeto foi a Reforma Bancária de 1964-1965. A partir dela estruturou-se um programa estatal de constante estímulo à concentração bancária, buscando ampliar as economias de escala dos bancos mediante a formação de redes bancárias nacionais como forma de angariar recursos (sobretudo por meio de depósitos) para financiar o desenvolvimento industrial do país.

Com o I e o II Plano Nacional de Desenvolvimento (I e II PND) da década de 1970, que buscavam "adequar a estrutura territorial a uma proposta de industrialização" (BECKER \& EGLER, 1994, p. 144), houve um aprofundamento da ação do Estado no território nacional.

Situou-se, dentro desses planos, o deslocamento da fronteira agrícola e mineral em direção ao Centro-Oeste e Norte, na década de 1970, que ocorreu concomitantemente à atração de contingentes populacionais para estas regiões, desencadeando o crescimento de antigas e novas cidades, que também se beneficiaram pelos efeitos multiplicadores para as atividades urbanas provenientes das demandas de insumos, máquinas, equipamentos, serviços bancários, comerciais etc. Nessa década, o crescimento industrial oriundo do chamado "milagre econômico" beneficiou diversos estados da federação em detrimento de São Paulo, reduzindo, pouco a pouco, o peso deste último na economia nacional e favorecendo a emergência de cidades de porte médio e grande (DINIZ, 2000).

Assim, a expansão da articulação da rede urbana brasileira abrangendo cada vez mais cidades do Centro-Oeste e Norte do país, junto da consolidação da rede urbana no Sudeste com a presença de inúmeras cidades de porte médio e grande, tiveram um efeito multiplicador sobre a estrutura territorial de poder no país. Isso porque a maior proximidade, amplitude e nível de renda dos mercados que demandavam serviços especializados, reforçaram o papel preponderante de São Paulo e do Sudeste dentro da formação socioespacial brasileira, permitindo-os projetar sua área de influência para outras regiões, assim como contrabalancear a influência externa no território nacional (ANDRADE, 1984). 
Foi nesse contexto de diferenciação urbano-regional, portanto, que foram implantadas e expandidas as infraestruturas de telecomunicações no Brasil. Segundo C. Gomes (2001, p. 345), no período compreendido entre os anos 1960 a 1980

deu-se a constituição de um sistema nacional de serviços interurbanos e internacionais, sob a égide do governo militar e desenvolvimentista, como o novo Ministério das Comunicações (criado em 1967) e as diversas participações empresariais.

Além da criação do Ministério das Comunicações, M. C. da Costa (1997) destacou a importância de outras medidas, tais como: a) criação do Código Brasileiro de Comunicações, em 1962, no qual foi estabelecido o controle governamental sobre o setor; b) criação, em 1965, da Empresa Brasileira de Telecomunicações (EMBRATEL); c) criação, em 1967 do Fundo Nacional de Telecomunicações (FNT) a ser pago pelo usuário; d) início da participação, por meio do Conselho Nacional de Telecomunicações (CONTEL), em 1967, do sistema de comunicações via satélite; e) criação, em 1972, da holding estatal Telecomunicações Brasileira S. A. (Telebrás); f) implantação do Centro de Pesquisas e Desenvolvimento (CPqD), em 1976.

Tratava-se, seguindo a análise empreendida por M. C. da Costa (1997, p. 1920), "de montagem do sistema" em meio a "uma política atrelada ao ideal militar de desenvolvimento dos setores estratégicos":

O setor cresceu, num primeiro momento, com recursos repassados do Fundo Nacional de Telecomunicações (FNT), além de outros recursos de agências financiadoras como FINEP, BNDES e empresas estatais como, por exemplo, a Companhia Vale do Rio Doce. Como desdobramento da mesma política, uma segunda orientação se estabelece: a capacitação técnica e produção local de equipamentos se fez também a partir de transferência de tecnologia das empresas multinacionais através de suas filiais no país, das quais é exigido o controle majoritário do capital nacional (política de nacionalização) (COSTA, 1997, p. 20).

A estruturação dos "troncos" de telecomunicações em direção ao Norte do país foi outro aspecto marcante dessa política de integração imaterial do território. Como ressaltou um dos relatórios feitos pela Superintendência de Desenvolvimento 
da Amazônia8 (SUDAM), de 1968: "No setor das telecomunicações, a Amazônia é a região mais sofrida do País" (SUDAM, 1968, p. 9).

Eram significativas as dificuldades de integração da Amazônia Oriental (Estado do Amazonas, Acre, Rondônia e Roraima) com as demais regiões, estando "quase totalmente isolada do resto do Brasil" (SUDAM, 1968, p. 19). Manaus, capital estadual e situada, para a Superintendência, "no centro geográfico da Amazônia", integrava o sistema de telecomunicações apenas por "radiotelegrafia, precário e sem capacidade de atendimento às necessidades das suas áreas de influência" (idem, p. 19).

Com a instituição de um grupo de trabalho, por meio da Portaria Ministerial 643, concluiu-se que seria necessária iniciar o processo de "interligação da Amazônia entre si e com o resto do Brasil, por meio de dois troncos: do Oeste, através de Manaus e Porto Velho, e do Leste, através de Manaus e Belém" (SUDAM, 1968, p. 20). O chamado "Tronco Leste", contemplava os Estados do Pará, Maranhão e Territórios Federais - à época - de Roraima e Amapá, enquanto o "Tronco Oeste" fixava sua abrangência sobre os Estados do Acre e Mato Grosso e o Território Federal de Rondônia. Assim, fixou-se a "configuração do Sistema Regional de Telecomunicações da Amazônia", que passou a ser implantado pela EMBRATEL, estabelecendo a interligação imaterial dessa região com o restante do país.

Dessa maneira, apesar de já existente no país desde 1957, foi somente em 1973 que a Embratel criou a Rede Nacional de Telex, expandindo-se, entre 1973 e 1986 de São Paulo e Rio de Janeiro para as principais capitais e regiões metropolitanas e, posteriormente, para outras localidades do país, mas, ainda, com tendência à seletividade (SANTOS \& SILVEIRA, 2001). Esta expansão, pautada em demandas empresariais, permitiu uma maior "segurança e rapidez na transmissão de informação a longa distância, além do barateamento dos custos de transmissão" (CORDEIRO, 1989, p. 5).

\footnotetext{
8 Em 1966, por meio da Lei 5.173/66, houve a criação da SUDAM e a instituição do Plano de Valorização da Amazônia. A divulgação desse relatório intitulado "Amazônia: desenvolvimento e ocupação", em 1968, deixa clara a importância que a questão da integração dessa região ao restante do país passou a ter para os militares. Além do diagnóstico e das propostas apresentadas acerca da integração das telecomunicações, o relatório apresenta ainda questões relativas à integração e produção energética e à continuidade das políticas de integração rodoviária, tendo como em Brasília seu "epicentro".
} 
Já em 1980, foi possível a criação da rede TRANSDATA, também pela Embratel. Conforme explicou T. Benakouche (1995, p. 229), era "constituída por circuitos privados do tipo ponto-a-ponto e explorada pela Embratel, destinada a atender a demanda por transmissão de dados por grandes usuários". Os bons resultados levaram a empresa a criar, em 1985, a rede RENPAC, de caráter público e "destinada ao atendimento de pequenos e médios usuários, isto é, clientes cuja demanda não justificavam a locação de um circuito privado (BENAKOUCHE, 1995, p. 229).

R. Castillo (1999, p. 175) observou que ambas se constituíram como "as primeiras redes de comunicações de dados no Brasil". Segundo o autor,

o RENPAC e o TRANSDATA são sistemas que, além de formar uma vasta rede de comunicação de dados no território, ainda permitem a conexão destas redes com redes similares de abrangência mundial. Possibilitaram a construção das primeiras redes eficientes de comunicação de dados no território brasileiro, permitindo a expansão territorial de empresas, sobretudo bancos, e contribuindo largamente para o aumento exponencial de fluxos informacionais (ordens, comando, controle, acesso a bancos de dados etc.) entre as principais cidades de um país de dimensões continentais, inaugurando os serviços telemáticos no Brasil (CASTILLO, 1999, p. 176).

Tais processos foram articulados com a extensão para o Brasil da rede ligada à Society for Worldwide Interbank Financial Telecommunications (SWIFT), em 1982 (DIAS 1996). Assim, conforme asseverou F. B. Contel (2011, p. 117),

Essa integração mais sofisticada do território (tanto do ponto de vista da circulação material, quanto informacional) vai ser utilizada pelo sistema bancário brasileiro, que passa a modernizar e difundir com mais vigor suas formas organizacionais e materiais pelo território. Pode-se dizer mesmo que a possibilidade de um comando mais centralizado das atividades econômicas (permitida pela utilização desta nova base informacional) é uma das responsáveis pela própria 'concentração bancária' que se intensificaria a partir do ano de 1964.

Assim, impulsionados pelo Estado - mas também pelos lucros obtidos com a inflação (LARANGEIRA e FERREIRA, 2000) -, diversos bancos puderam ampliar suas escalas de atuação e investir na ampliação do uso dos novos sistemas técnicos automatizados. Com as novas possibilidades de circulação informacional no território, junto dos avanços técnicos relativos ao processamento distribuído de dados, ao longo da década de 1970 progressivamente uma nova estratégia de automação passou a ganhar corpo por parte das instituições bancárias: a integração 
eletrônica das redes de agências de cada banco, descentralizando a transmissão e processamento de dados também para as agências.

Dessa maneira foi possível expandir o uso de computadores, incluindo os de grande porte, e reorganizar as formas de atuação da atividade bancária. Como mostrou H. Pires (1997, p. 5), "as modificações na estrutura tecnológica do hardware implantado e dos sistemas de telecomunicações influíram nas formas territoriais de gestão centralizadas das informações em grandes CPDs [Centro de Processamento de Dados]."

Inicialmente concentrados nas metrópoles e posteriormente expandidos para alguns centros regionais, os Centro de Processamento Dados (CPDs) engendraram uma nova forma de organização da atividade bancária: os dados das agências passaram a ser digitados e transmitidos diariamente para os CPDs que, por sua vez, os processavam, atualizavam e transmitiam de volta para as respectivas agências (DINIZ, 2004).

Esses novos sistemas técnicos, integrados às redes de telecomunicações, levaram a um melhor aproveitamento das novas formas de gestão, transmissão e processamento da informação a partir de mini e microcomputadores. A automação e transmissão de dados direto das agências foi a forma mais comum de descentralizar o processamento das informações e integrar as redes bancárias funcionalmente e territorialmente. A integração das informações inseridas pelos caixas aos CPDs ocorreu com a aquisição e instalação de minicomputadores e de microcomputadores que, integrados em redes de telefonia, centrais PABX e telex, permitiram transmitir e processar as informações ainda com maior velocidade ${ }^{9}$. Nesse momento, portanto,

As modificações na estrutura do hardware, permitindo o estabelecimento de fluxos e nexos informacionais e comunicacionais remotos distribuídos, se constituiu num fator crucial no processo de descentralização das decisões interbancárias e intrabancárias. A digitação remota efetuada por telex, a transmissão e impressão remota por comutador e o processo a longa distância por telefone e fax foram fatores decisivos no processo de descentralização do processamento de dados. Os CPDs passaram a armazenar menos volumes informacionais (PIRES, 1995, p. 160).

\footnotetext{
${ }^{9}$ Segundo W. Hoff (2003), no Banco do Brasil os primeiros CPDs foram instalados e utilizados ao longo da década de 1970, enquanto que, nas agências, os primeiros computadores foram instalados ao longo da década de 1980. Já C. Frischtak (1992) enfatizou que muitos bancos aceleraram a instalação de computadores nas agências ao longo de toda a década de 1980.
} 
Figura 4 - Comunicação de dados por Telex no Banco Bradesco

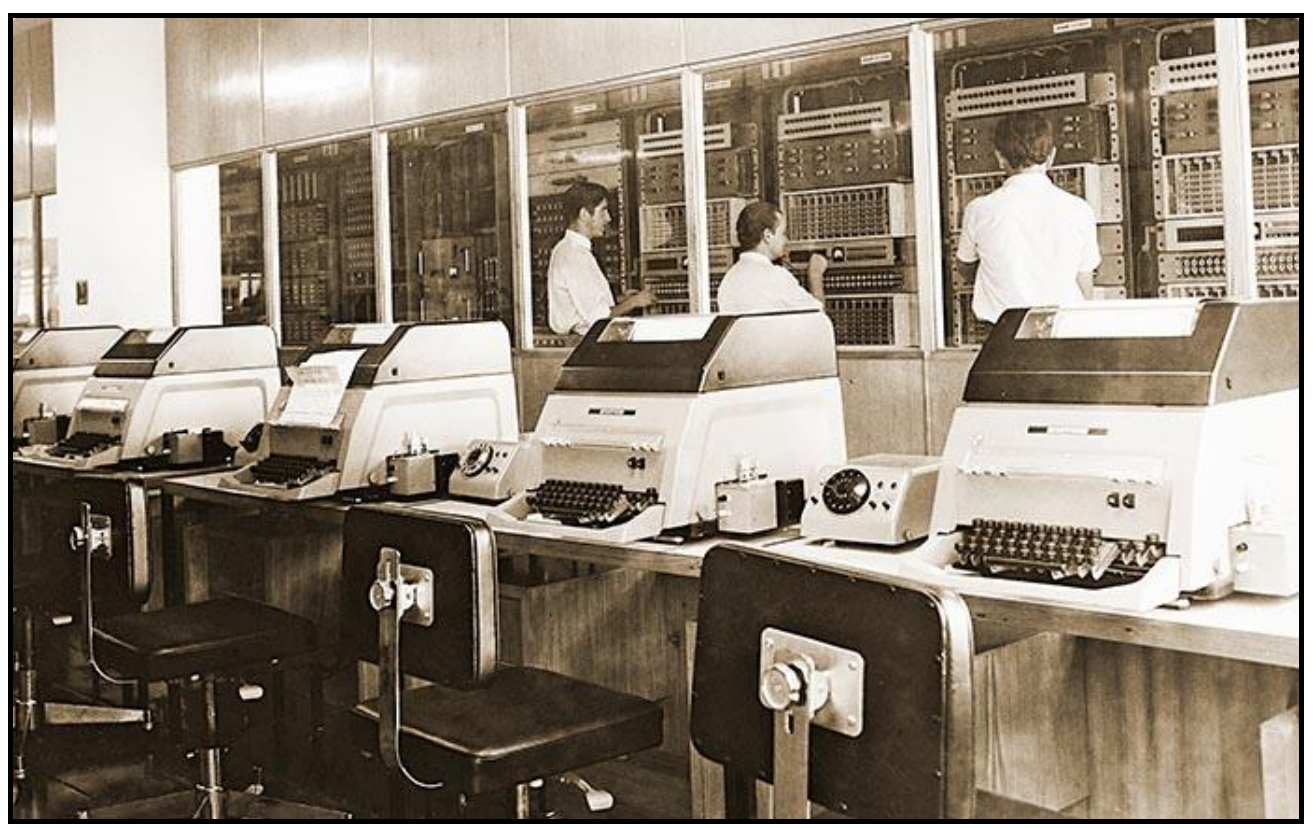

Fonte: Sítio eletrônico da instituição.

Figura 5 - Centro de Processamento de Dados do Bradesco (anos 1970)

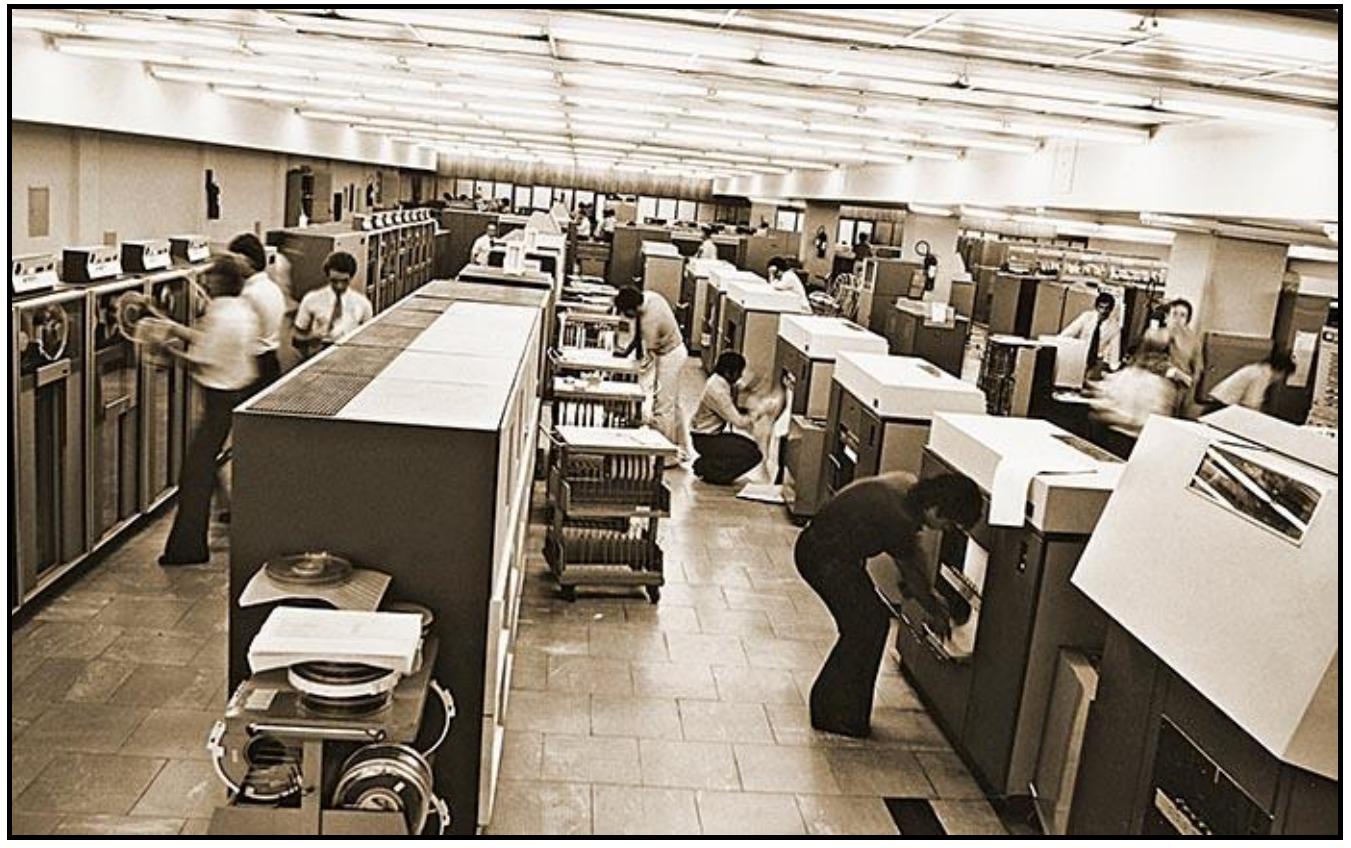

Fonte: Sítio eletrônico da instituição.

Consolidou-se, nesse sentido, a divisão territorial do trabalho bancário, com a separação espacial das atividades administrativas e das tarefas de prospecção, envolvimento e recepção ao cliente (VERDIER, 1986). Trata-se do que L. Blass (1993) caracterizou como a "fragmentação das tarefas bancárias", desde a sua concepção nos centros administrativos até a execução nas agências e centros de 
processamentos de dados, seguindo a busca pela produção em massa mediante tarefas padronizadas, repetitivas e ditadas por papéis e documentos.

A informação financeira presente no sistema bancário passou a adquirir também um estatuto de informação de classe (BOLAÑO, 2000), desigualmente concentrada e hierarquicamente distribuída por meio de um controle da concepção e matematização dos métodos de trabalho, o que, em certa medida, acirrou as diferenciações entre as profissões existentes e também desigualmente distribuídas na formação socioespacial brasileira.

Vale dizer que o sentido dessa informação era de caráter unidirecional definido pela burocracia bancária nas sedes -, responsável por pautar e hierarquizar os trabalhos em agências e demais fixos.

Assim, foram configuradas as formas-conteúdo necessárias para a circulação das informações financeiras cujos centros-focais eram agências, um primeiro conjunto de caixas eletrônicos (ATMs), assim como os CPDs, sedes e centros de gestão. Por conta de seu caráter classista e unidirecional podem ser caracterizados dentro do que A. Bernardes (2010) definiu como círculos descendentes de informação, cuja finalidade era a realização e organização de um trabalho verticalizado, direcionado, burocratizado, preciso e específico, além de concebido e controlado por certos grupos profissionais estrategicamente localizados no território nacional.

Esses elementos permitem elaborar uma reflexão sobre como as novas práticas de gestão tornaram-se expressão das novas formas de exercício do poder, tal como sugeriu A. C. T. Ribeiro (1991). Utilizando-se as palavras desta autora, pode-se dizer que a "nova estrutura socioespacial" resultante dos projetos modernizadores dos governos autoritários no Brasil, "permite reconhecer a existência de desigualdades sociais e territoriais criadas e recriadas pela expansão técnica que sustenta a atual estrutura de operação e domínio da circulação de mensagens, imagens e informações" (RIBEIRO, 1991: 49).

É importante ressaltar que, nesse momento, a influência de São Paulo era balizada e contrabalanceada pela existência do Banco do Brasil e da Caixa Econômica Federal cujas sedes eram localizadas em Brasília. Também era minimizada pela presença dos Bancos Públicos Estaduais, que, como ressaltou A. 
Moura (2007), contribuíam para dar uma maior margem de autonomia aos governos estaduais para decisões políticas estratégicas e de alocação do crédito.

Pode-se falar, portanto, que esse período foi marcado pela consolidação de grandes redes bancárias nacionais que, apoiadas na expansão das infraestruturas de telecomunicações, nas políticas para a área de informática e na busca pela desconcentração da oferta de serviços, expandiram significativamente suas respectivas topologias e formas de atuação, ao mesmo tempo em que concentraram ainda mais as atividades de gestão mediante a centralização do comando do sistema bancário (CONTEL, 2006). 


\section{Automação bancária e o circuito espacial de produção de ATMs: da crise dos anos 1980 às reorganizações dos anos 1990}

Nesse capítulo, buscou-se entender como o circuito espacial de produção de ATMs e os processos de automação bancária foram influenciados pelas diferentes conjunturas do país a partir da crise dos anos 1980, pelo processo de abertura comercial e pelas políticas de reestruturação bancária.

\subsection{Abertura comercial e desestabilização das empresas do circuito espacial de produção de ATMs}

Durante a década de 1970, em grande parte devido aos esforços realizados pelo governo federal desde o I e, sobretudo, no II PND, instalam-se definitivamente no território um conjunto de empresas nacionais, com ampliação do processo produtivo dentro do país e aumentos dos investimentos bancários nas indústrias de informática. Desde então, é possível falar no estabelecimento de um circuito espacial de produção ATMs em território nacional.

Todavia, no final da década de 1970 e início dos anos 1980, do ponto de vista do cenário macroeconômico, houve a eclosão e aprofundamento de uma forte crise econômica e política, em que foi posto em cheque o regime militar, mas também passou a ser questionado o caráter das medidas tomadas pelo chamado Estado Nacional-Desenvolvimentista ${ }^{10}$.

\footnotetext{
${ }^{10}$ Segundo C. A. Pacheco (1998, p. 72 e 73) o período que vai de 1979 até a primeira metade da década de 1990 marcou "a mais grave crise da história do Brasil contemporâneo. A recessão e a elevação do desemprego do início e do fim desse período assumiram uma dimensão até então desconhecida". De forma geral, o autor apresenta a seguinte relação entre planos econômicos e conjunturas do país: "Um exame da política econômica revela um conjunto muito variado de tentativas de ajustes, com conjunturas muito diversas, cobrindo desde as iniciativas 'heterodoxas' de 1979/80; a recessão de 1981/83; o início da recuperação via exportações (1984/85); os efeitos de crescimento do Plano Cruzado (1986); uma série de tentativas de estabilização entrecortadas por novas acelerações inflacionárias entre 1987/1989; a recessão de 1991/93, no contexto da drástica abertura comercial do país; até chegar ao Plano Real, com o crescimento de 1993/94 e a desaceleração posterior. Fica claro que a tônica desses quinze anos é a de alternância entre ciclos de recuperação e crescimento" (PACHECO, 1998, p. 73).
} 
Em tal contexto, é possível destacar os seguintes elementos (DUPAS, 1987; SUIZIGAN, 1989):

1. Forte endividamento externo, originado durante toda a década de 1970, que gerou um rápido aprofundamento da crise no período pós1979, com o desequilíbrio da balança comercial, a deterioração das relações de troca dos produtos exportados pelo Brasil aos países desenvolvidos (a despeito dos significativos esforços, ainda vigentes, de substituição de importações) e fraco crescimento do Produto Interno Bruto;

2. Desestabilização da moeda, com o declínio das reservas internacionais e o aumento da inflação desde 1979 até o seu “estouro" em 1983 e novamente em 1985/1986;

3. Forte redução dos investimentos privados estrangeiros e transferência líquida de recursos ao exterior, impulsionados pela elevação nos preços do petróleo de 1979 e pela crise financeira internacional de 1982 ;

4. Política de arrocho salarial, limitando os aumentos salariais e reduzindo o salário real, efetivada pelo governo federal e estimulada pelo Fundo Monetário Internacional, cujos objetivos eram complementar-se à política de câmbio, reduzindo o consumo interno e produzindo excedentes exportáveis. Tal política, embora oscilando e com diferentes nuances, permaneceu vigente de 1979 a 1986 a um custo social altíssimo, com a deterioração da distribuição de renda no país, ampliação de movimentos sindicalistas e a eclosão de greves;

5. Estabelecimento da Política Nacional de Informática, em 1984, garantindo o arcabouço legal da reserva de mercado e aprofundando "a percepção de que é fundamental para o Brasil de transição, a definição de uma política industrial que inclua ao seu vetor mais importante, o desenvolvimento tecnológico" (DUPAS, 1987, p. 51). No entanto, houve o veto a 26 artigos, incluindo os relativos ao Fundo Especial de Informática e de Automação. Tal política foi complementada pelo Plano Nacional de Informática (PLANIN), em 1986; 
6. Estabelecimento de políticas industriais e medidas liberalizantes, a partir de 1987, anunciando-se "como princípios de política industrial a importação de tecnologias, a total desregulação da economia, liberdade ao capital estrangeiro estabelecer fábricas de 'qualquer natureza', criação de zonas de processamento de exportação inteiramente desvinculadas da estrutura industrial existente" (SUIZIGAN, 1989. p. 291).

Tais processos tiveram inúmeras consequências tanto para o sistema bancário, quanto para a produção e organização da indústria ${ }^{11}$ na formação socioespacial brasileira. Conforme ressaltou W. Suzigan (1989, p. 288), entre seus resultados, de 1981 a 1983, houve forte queda da produção industrial na ordem de $17 \%$, redução pela metade dos níveis de investimento, queda de $20 \%$ no nível de emprego na indústria e capacidade ociosa industrial, em média, de $25 \%$.

Considerando, ainda, a relação entre questões macroeconômicas, política de reserva de mercado e empresas nacionais de informática, deve-se ressaltar que, embora tenha havido uma recuperação positiva dos saldos de exportação e o retorno do crescimento econômico e industrial no país no período pós-1984,

a competividade alcançada foi 'espúria' porque obtida através de desvalorização cambial, acompanhada de restrições à demanda interna e compressão do salário real, e não através do aumento da produtividade e incorporação do progresso técnico. (...) A política de reserva de mercado para a indústria de informática foi, até certo ponto, uma exceção. De fato, essa política contribuiu efetivamente para a implantação do segmento de mini e microcomputadores por empresas privadas nacionais, e se constitui num instrumento válido, utilizado pela maioria dos países que implementaram políticas visando à implantação e consolidação de indústrias de tecnologia de ponta (SUIZIGAN, 1989, p. 289).

\footnotetext{
${ }^{11}$ Segundo A. Mergulhão (2016, p. 167) a "década de 1980 é caracterizada por profunda crise econômica, grande parte com origem no fim do ciclo expansivo iniciado em 1968 e dos choques do petróleo de 1973 e 1979, bem como consequência das políticas monetárias e fiscais adotadas". Buscando sintetizar a discussão da autora, de modo a aprofundar os elementos apresentados anteriormente, pode-se destacar as seguintes medidas políticas (MERGULHÃO, 2016, p. 167-170): 1) busca inicial de correção das distorções oriundas do "alto grau de dependência das importações de matéria prima" e do "elevado fluxo de empréstimos favorecido pelas facilidades da liquidez internacional" por meio de "adoção de forte política recessiva a partir de 1981. Em abril, há alta de 15\% das taxas para importar (com lista de exceções), bem como alto controle sobre importações exercidas pela Câmara de Comércio Exterior"; 2) tal política foi seguida pela redução da taxa de subsídios e de proteção tarifárias e, no ano de 1982, por um "menor rigor das políticas monetárias [que] permite pequena alteração no patamar de crescimento do ramo industrial brasileiro"; 3) novas medidas, em 1983, buscando a redução da dívida externa e inflação "com políticas mais restritivas de crédito e gastos, maxidesvalorização da moeda e outros incentivos às exportações. Como consequência, há desestímulo à demanda interna, retração do PIB com contribuição do ramo industrial para o resultado negativo"; 4) "retomada o resultado positivo da economia se dá pelo aumento das exportações, sendo a indústria a atividade que mais contribui para este resultado".
} 
Nesse sentido, seguindo a análise de C. A. Pacheco (1998), a partir de 1970 e até o final da década de 1980, ganharam força dois importantes processos de reorganização espacial da atividade industrial: a desconcentração, no Brasil como um todo; e a interiorização, no Estado de São Paulo.

Do ponto de vista da escala nacional, houve a perda de participação dos Estados de São Paulo e do Rio de Janeiro no Valor de Transformação Industrial. A participação de São Paulo reduziu de 58,1\% em 1970, para 51,9\% em 1985; já o Rio de Janeiro teve reduzida sua participação de $15,7 \%$ para 9,5\% no total nacional no mesmo período. Conforme salientou C. A. Pacheco (1998, p. 121),

O produto industrial brasileiro era, em 1985, cerca de 2,3 vezes maior que o de 1970, e embora esse aumento seja também um resultado do crescimento real do produto industrial do Rio de Janeiro e São Paulo, cerca da metade dessa expansão ocorreu em outras Unidades da Federação.

Esses processos de desconcentração, influenciados pelos Planos de Desenvolvimento dos governos militares dos anos $1970^{12}$ - e por processos específicos dos anos $1980^{13}$-, ocorreram em "dois sentidos": "de um lado, as regiões Norte, Centro-Oeste, os estados da Bahia, Paraná e Minas Gerais; de outro, o interior de São Paulo" (PACHECO, 1998, p. 119).

A esse respeito, M. Santos e M. L. Silveira (2001, p. 106) apontaram também que, ao longo dos anos 1970 e 1980, houve uma complexificação da produção industrial no país, com sua extensão "sobretudo para novas áreas do Sul e para alguns pontos do Centro-Oeste, do Nordeste e do Norte (Manaus)". Concomitantemente, observaram a existência de um movimento paralelo: "as áreas

\footnotetext{
12 'O exame dos determinantes desta 'interiorização' ou da desconcentração a favor do restante do país revela, em ambos os casos, um acentuado peso para as decisões de política econômica, ou de investimentos associados a elas, tomadas na segunda metade dos anos 70. Muitos desses investimentos, em particular as metas mais ambiciosas do II PND, acabaram sendo revistos e dilatados no tempo, favorecendo a continuidade desses processos na primeira metade da década de 80 . E, se as informações disponíveis dão conta que a desconcentração ainda se fez presente na segunda metade da década de 80 , é conveniente ter em vista que esse processo mostrou-se bem menos intenso que no período 1970/80" (PACHECO, 1998, p. 132).

${ }^{13}$ Sobre a questão da desconcentração nas décadas de 1970 e 1980, A. Mergulhão (2016, p. 170-171) faz uma importante ressalva: "Enaltecemos que a desconcentração geográfica industrial assume papéis bem diferentes daqueles do início dos anos 1970. Naquela década, o grau de abertura da economia é menor, há forte intervenção estatal e não há mudança significativa de padrão tecnológico. Os principais determinantes do fenômeno são as deseconomias de aglomeração na RMSP em conjunto com a criação de novas economias de aglomeração em outras áreas. A partir de meados da década de 1980, há novos requisitos locacionais, dentre eles facilidade para inovação, acesso a serviços bem mais modernos, centros de ensino e pesquisa".
} 
industriais já consolidadas ganham dinamismos diferentes dos que definiram a industrialização em períodos anteriores" (SANTOS \& SILVEIRA, 2001, p. 106).

Segundo esses autores, a região Sul do país despontava, no final da década de 1980 , como

a região ganhadora nesse rearranjo do trabalho industrial no Brasil. (...). Em 1970, enquanto essa região acolhia apenas $14,79 \%$ do pessoal ocupado do país, São Paulo concentrava 50,97\%. Vinte anos depois, São Paulo reunia 35,35\% do emprego industrial e a região Sul, que já havia ultrapassado esse umbral, ostentava 36,49\% do total nacional (SANTOS \& SILVEIRA, 2001, p. 107).

Para o caso específico do Estado de São Paulo, é importante destacar que, embora a Região Metropolitana e o município de São Paulo tenham crescido isoladamente, ambos sofreram queda relativa de participação na produção e no emprego (em relação ao Estado), enquanto o interior obteve aumento relativo no mesmo período ${ }^{14}$.

Em função das indústrias necessitarem de "baixos custos de localização desde que com infraestrutura satisfatória", emergiram "novos núcleos industriais" (MERGULHÃO, 2016, p. 169), fortaleceu-se a presença de estabelecimentos industriais em Campinas, São José dos Campos, Ribeirão Preto, Sorocaba e Santos (PACHECO, 1998).

Segundo A. Mergulhão (2016, p. 169), essa queda de participação não refletiu, todavia, uma redução da desigualdade no estado de São Paulo "justamente porque há expansão da área de influência da RMSP, queda na participação das atividades típicas da segunda revolução industrial, (...) além da contratação de mão de obra cada vez mais barata". Deve-se destacar, também, que, em sua maioria, "as atividades que permanecem na RMSP demandam serviços especializados, relações estreitas entre fornecedores e consumidores, fluxos rápidos de informações, mão de obra especializada" (MERGULHÃO, 2016, p. 169)

\footnotetext{
14 "Entre 1970 e 1990, o número de estabelecimentos e o valor da transformação industrial crescem significativamente no interior do Estado. Enquanto em 1970 a Região Metropolitana reunia 36,09\%, o município de São Paulo 28,94\% e o interior apenas 6,95\% do total nacional de estabelecimentos, duas décadas mais tarde as participações respectivas eram de $21,95 \%, 9,23 \%$ e $15,26 \%$. Situação semelhante é a do valor de transformação industrial. Nesse mesmo intervalo, a participação da Região Metropolitana de São Paulo caiu de $45,29 \%$ para $31,13 \%$ e a do município passou de $28,39 \%$ para $16,01 \%$, ao tempo em que a do interior aumento de $13,13 \%$ para $21,70 \%$. Todavia, quanto às pessoas ocupadas na indústria, diminui substancialmente a participação relativa do Estado de São Paulo no total nacional, como também a da Região Metropolitana, do município e do interior do Estado" (SANTOS \& SILVEIRA, 2001, p. 108).
} 
Outro aspecto fundamental da indústria em meados dos anos 1980, diz respeito ao fato que a referida tendência à desconcentração acabava por revelar especializações regionais. Além disso, ela era influenciada, igualmente, pela ainda existente concentração industrial de São Paulo, sobretudo no que diz respeito aos "mais dinâmicos segmentos da indústria, que se encadeiam com toda estrutura industrial do estado e com a maior parte das indústrias regionais" (PACHECO, 1998, p. 129).

É importante destacar a participação do ramo de material elétrico e comunicações, complementar e condição para as indústrias de informática, cuja presença ocorria principalmente na região Sudeste, seguida pelo Sul do país (SANTOS \& SILVEIRA, 2001, p. 108).

Nesse ramo, especificamente, destacavam-se os Estados de São Paulo e do Paraná. Além desses estados e regiões do país, havia também a presença de empresas na Zona Franca de Manaus, que respondia, em 1985, por 12,5\% do Valor de Transformação Industrial desse segmento no Brasil ${ }^{15}$. Assim, a maior presença e densidade das indústrias nos diferentes estados brasileiros, favoreceu um aprofundamento e complexificação da divisão do trabalho inter e intra-regional no país, em um processo no qual a indústria de informática foi ao mesmo tempo beneficiária e contribuinte.

As políticas industriais dos anos 1970, inclusive para a informática, somadas aos investimentos dos bancos de grande porte para ampliarem e interligarem seus fixos (sobretudo as agências) no território nacional - junto ainda das iniciativas de automação dos bancos públicos estaduais e de bancos de pequeno e médio porte -, foram iniciativas que contribuíam para sustentar em diversas localidades do país as indústrias de objetos técnicos bancários nascentes.

Esses são fatores importantes para a compreensão da presença de indústrias deste tipo no Paraná, Santa Catarina e Rio Grande do Sul e em São Paulo. Todavia, nesse último estado deve-se levar em conta a presença de outros fatores endógenos, como a emergência de cidades de porte médio e a presença de uma

\footnotetext{
15 “Ainda que reúna outros tipos de indústria (ótica, produtos de matéria plástica, informática, etc.), a eletrônica de consumo é o principal segmento produtivo da ZFM, montado com base num amplo sistema de incentivos fiscais, que tem por base diferenciais de alíquotas de Imposto sobe Produtos Industrializados e Imposto de Importação, tanto para similares importados, quanto para a produção nacional de outras regiões" (PACHECO, 1998, p. 149).
} 
importante rede de ensino e pesquisa. Também deve-se levar em conta o fato que, embora com perda de sua participação no conjunto do país, a atividade industrial paulista continuou crescendo durante toda a década de 1970 e 1980, o que favoreceu essa sustentação regional das atividades de informática.

Ainda que a empresa estatal Cobra já houvesse começado a registrar forte queda em suas receitas diante do aumento da concorrência e do contexto recessivo do país, tal fato não pode ser atribuído a todas as empresas do circuito espacial de produção de objetos técnicos bancários. Conforme ressaltou H. Pires (1995, p. 93),

neste processo de reestruturação industrial, no setor eletroeletrônico a área de atividade que chama mais a atenção é a de informática (...), principalmente o de automação bancária que na década de 80 (DEPIN, 1991), mesmo no período de esgotamento do modelo de substituição de importações, em um contexto inflacionário e pré-recessivo, teve um crescimento excepcional

Para essas empresas, foi possível manter suas topologias necessárias às suas respectivas produções e até mesmo expandir suas atividades até os anos 1990 - e em grande medida contra a corrente de crise macroeconômica dos anos 1980 -, devido a três principais fatores:

a) Lucros inflacionários e enxugamento dos quadros de trabalhadores com grandes "ondas" de demissão por parte dos bancos comerciais sobretudo os privados existentes à época -, que liberavam excedentes a serem direcionados sob a forma de investimentos para a compra de equipamentos ligados à automação;

b) Manutenção e institucionalização da política de reserva de mercado, que garantia às indústrias nacionais um mercado privilegiado de computadores de pequeno e médio porte, equipamentos eletrônicos e periféricos e terminais de autoatendimento (ATMs);

c) Concorrência entre os bancos comerciais à época que os levavam a investir em novas áreas de automação - como foi o caso dos investimentos nas primeiras redes de ATMs na década de 1980.

Dessa forma, no final da década de 1980, conforme ressaltado por H. Pires (1995), o "nicho" do mercado da automação bancária ainda era disputado por empresas nacionais. No caso do circuito espacial de produção de ATMs, destacavam-se a Itautec, a SID, a Procomp e o Banco 24 horas (Tecban). 
Localizavam suas sedes e fábricas majoritariamente em São Paulo (e na sua Região Metropolitana), no Rio de Janeiro, Curitiba e, em alguns casos, suas fábricas em Manaus, configurando uma topografia do circuito convergente às localizações da indústria de alta tecnologia estabelecidas nas décadas de 1970 e 1980.

Foi justamente nesse contexto que atuou a reorientação e reformulação política sob o governo de Fernando Collor, entre 1990 e 1992. Em seu discurso de posse no Congresso $\mathrm{Nacional}^{16}$, o então presidente anunciava que seu governo atuaria, entre outros grandes temas, no combate à inflação, na reforma do Estado e na modernização econômica.

Colocando a estabilização monetária e financeira como prioridade absoluta, anunciou que a "austeridade, ao lado da eficiência, [seriam] a marca constante da atuação do Estado e um motivo de orgulho do funcionalismo federal". Também definia nesse momento "a guerra contra a inflação" como "uma luta incondicional", considerando-a como "um combate condicionante de tudo mais: da retomada do investimento, da consolidação do crescimento, da conquista de melhores níveis sociais, do fortalecimento da democracia".

Outro ponto extremamente relevante, do discurso governamental, era a associação entre a estabilização financeira e necessidade de "saneamento" das finanças do Estado: tornava-se "imperativo equilibrar o orçamento federal, o que supõe reduzir drasticamente os gastos públicos". Nesse sentido, era preciso "adequar o tamanho da máquina estatal à verdade da receita", assim como acabar com "a concessão de benefícios, com a definição de privilégios que, independentemente de seu mérito, são incompatíveis com a receita do Estado".

Sendo assim, era preciso redefinir "com toda a urgência, o papel do aparelho estatal entre nós". Entendia-se que competia "primordialmente à livre iniciativa não ao Estado - criar riqueza e dinamizar a economia". Já ao Estado corresponderia "planejar sem dirigismo o desenvolvimento e assegurar a justiça, no sentido amplo e substantivo do termo". Ressaltou-se, por fim, que "essa proposta

16 "O projeto de reconstrução nacional - Discurso de posse no Congresso Nacional", de 15 de março de 1990. As citações que seguem pertencem a esse mesmo documento. Disponível em: http://www.biblioteca.presidencia.gov.br/presidencia/ex-presidentes/fernando- 
de modernização econômica pela privatização e abertura é a esperança de completar a liberdade politica, reconquistada com a transição democrática, com a mais ampla e efetiva liberdade econômica".

Foi com base nesse discurso que, seguindo a definição e caracterização de B. Sallum Jr. (2001, p. 324-325), a partir desse momento começou a estabelecer-se uma "ruptura significativa com o (sic) velho padrão nacional-desenvolvimentista", voltando-se para uma "integração liberal da economia doméstica ao sistema econômico nacional".

Assim, as iniciativas governamentais desdobraram-se em inúmeras medidas, como a decisão, em reunião ministerial pela "suspensão de todos os subsídios, incluídos os dos exportadores e da informática" ${ }^{17}$. No que diz respeito às barreiras à importação, entre 1989 e 1993, houve significativa redução das tarifas alfandegárias médias, que "passaram de 31,6\% em 1989 para 30\% em setembro de 1990, 23,3\% em 1991, 19,2\% em janeiro de 1992, 15\% em outubro de 1992 e 13,2\% em julho de 1993, seis meses antes do cronograma inicialmente fixado" (SALLUM JR, 2001, p. 325-326).

Deve-se destacar que também adotaram-se progressivamente as seguintes iniciativas (SALLUM JR., 2001, p. 325): a) suspensão das barreiras não tarifárias às compras no exterior; b) programa de redução progressiva das tarifas de importação ao longo de quatro anos; c) desregulamentação das atividades econômicas; d) "encolhimento do braço empresarial do Estado (privatizações) para recuperar as finanças públicas e reduzir aos poucos o seu papel na impulsão da indústria doméstica"; e) política de integração regional: "materializada na construção do Mercosul (1991) tinha como horizonte ampliar o mercado para a produção doméstica dos países-membros".

Seguindo essa nova orientação de projeto para o país, entre 1990 e 1991 quatro diferentes medidas foram elaboradas pelo governo federal tendo em vista a busca por um redirecionamento da Política Industrial:

17 "Primeira reunião ministerial: programa econômico", de 16 de março de 1990. Disponível em: http://www.biblioteca.presidencia.gov.br/presidencia/ex-presidentes/fernando- 
- Diretrizes Gerais para a Política Industrial e de Comércio Exterior (de 26 de junho de 1990);

- Programa de Apoio à Capacitação Tecnológica da Indústria Brasileira - PACT (instituído em 19 de setembro de 1990);

- Programa Brasileiro de Qualidade e Produtividade - PBQP (instituído em 7 de novembro de 1990);

- Programa de Competitividade Industrial - PCI (instituído em 27 de fevereiro de 1991);

O documento elaborado pelo Ministério da Economia, intitulado Diretrizes Gerais para a Politica Industrial e de Comércio Exterior ${ }^{18}$, ao condicionar a política industrial ao programa de estabilidade, estruturou todas as demais políticas industriais e definiu os objetivos, as estratégias, os papéis específicos do Estado, do capital privado nacional e do capital estrangeiro, assim como os mecanismos políticos e os instrumentos a serem utilizados.

No que diz respeito aos objetivos, buscava-se o "aumento da eficiência na produção e comercialização de bens e serviços, mediante a modernização e a reestruturação da indústria". Essa finalidade, de caráter mais geral, desmembravase em outros dois direcionamentos específicos:

i) Modernização industrial e comercial, mediante a busca pelo "aumento da produtividade e por padrões internacionais de qualidade, a serem alcançados com base em crescente capacitação tecnológica";

ii) “implementação de modernas estruturas de produção e consumo de bens e serviços em todo o espaço econômico nacional, pela difusão de novos padrões tecnológicos".

Já nas estratégias, foi estabelecido que seriam necessárias "formas de atuação governamental e de regulação da atividade econômica substancialmente diferentes daquelas vigentes ao longo do processo de substituição de importações". A partir de então, acreditou-se que as chamadas "forças de mercado" deveriam ser utilizadas "de forma mais eficaz", de modo a "induzir a modernização tecnológica do parque

18 Instituída por meio da Portaria MEFP $\mathrm{n}^{\mathrm{o}} 365$, de 26 de junho de 1990. Disponível em: http://www.infoconsult.com.br/legislacao/portaria_mefp/1990/p_mefp_365_1990.htm 
industrial e para aperfeiçoar as formas de organização da produção e da gestão do trabalho". Sendo assim, acreditou-se ser necessário:

a) redução progressiva dos níveis de proteção tarifária, eliminação da distribuição indiscriminada e não transparente de incentivos e subsídios e fortalecimento dos mecanismos de defesa da concorrência, constituindo um ambiente interno mais competitivo;

b) reestruturação competitiva da indústria, através de mecanismos de coordenação e mobilização, de instrumentos de apoio creditício e de fortalecimento da infraestrutura tecnológica;

c) fortalecimento de segmentos potencialmente competitivos e do desenvolvimento de novos setores, através da maior especialização da produção;

d) exposição planejada da indústria brasileira à competição internacional, possibilitando a inserção mais favorável da economia brasileira no mercado externo, a melhoria progressiva dos padrões de qualidade e preço no mercado interno, e o aumento da competição em segmentos industriais oligopolizados;

e) capacitação tecnológica das empresas nacionais, entendida como a capacidade de selecionar, absorver, melhorar ou desenvolver tecnologias, através da proteção tarifária seletiva de segmentos das indústrias de tecnologia de ponta e do apoio à difusão das inovações nos demais setores da economia. (BRASIL, Portaria MEFP $\mathrm{n}^{\circ} 365$, de 26 de junho de 1990).

Dessa forma, desdobraram-se inúmeras mudanças, em relação a políticas e legislações industriais anteriores, acerca do entendimento do papel do Estado e do capital privado no desenvolvimento produtivo nacional.

O documento estabeleceu que ao Estado caberia "garantir a estabilização macroeconômica e a reconstrução de um ambiente favorável aos investimentos em geral, com o estabelecimento de regras claras e estáveis para a vida econômica". Deveria, igualmente, estar voltado "exclusivamente às suas funções básicas e recuperada sua capacidade de poupar, (...) abrindo espaço para que o capital privado exerça plenamente seu papel de principal agente do processo produtivo". Para o governo à época, as principais atribuições estatais deveriam ser: reforçar "o sistema educacional básico e a estrutura de desenvolvimento científico e tecnológico", assim como "do setor público dentro da infraestrutura de competitividade do País". Vale ressaltar que, complementarmente às inciativas governamentais, "o setor privado terá presença crescente na medida em que as empresas invistam mais em pesquisa e desenvolvimento".

No que tange à importância do capital privado, este teria que se direcionar no sentido de uma "participação crescente do setor privado como produtor de bens e 
serviços básicos (energia, transporte, portos, armazenagem, siderurgia de planos, petroquímica, fertilizantes, telecomunicações e outros) ". Dessa forma, haveria uma busca pela redução da "responsabilidade do setor público enquanto produtor nessas atividades" e redefinição do "ambiente econômico em que operam as grandes companhias estatais".

O Capital Privado Nacional, deveria ser "estimulado a reestruturar-se e fortalecer-se para que possa participar de forma ativa nesta nova etapa em que as exigências de competitividade serão crescentes, com a inserção internacional e o fim da tutela do Estado colocando novos desafios e oportunidades para empresas e empresários brasileiros".

Por outro lado, o Capital Estrangeiro, via investimento direto estrangeiro no país, passou a ser colocado como "importante fator na recuperação da taxa de investimento, na expansão do comércio internacional e no acesso à tecnologia". Sobre a questão tecnológica, deveria ser estimulado um "maior envolvimento das empresas estrangeiras em atividades de pesquisa e desenvolvimento no País".

O documento também se direcionou no sentido de estabelecer o "modelo empresarial a ser seguido" pelo setor privado:

Grupos empresariais de grande porte, articulados a uma extensa malha de pequenas e médias empresas tecnologicamente dinâmicas, competindo e associando-se das mais variadas maneiras com empresas estrangeiras, deverá ser o modelo empresarial a ser perseguido (BRASIL, Portaria MEFP n 365, de 26 de junho de 1990).

Dentro desse quadro de referência político-normativo especificaram-se os mecanismos e instrumentos da Política Industrial e de Comércio Exterior. A busca por maior competitividade internacional - sem qualquer preocupação e referência às reais necessidades de desenvolvimento do mercado interno - passou a pautar essa política, nesse momento, por meio de uma orientação para a reestruturação, modernização e capacitação tecnológica em "setores geradores do progresso tecnológico". Assim, foram instituídos: o Programa de Competitividade Industrial (PCI) e o Programa Brasileiro da Qualidade e Produtividade (PBQP).

O primeiro tinha como finalidades: i) "o desenvolvimento dos setores de tecnologia de ponta, aí incluídos a informática, a química fina, a biotecnologia, a mecânica de precisão e os novos materiais"; e ii) "a reestruturação dos setores 
industriais e de serviços que possam alcançar preços e qualidade em padrões internacionais". Esse Programa estabeleceu ainda que em "setores que, cumulativamente, tenham como característica um desenvolvimento tecnológico rápido, escalas técnicas de produção elevadas e alta concentração de capital" seriam "estimuladas fusões e incorporações, buscando um número de produtores adequados à estrutura da competição internacionais".

Já o segundo programa, buscava "apoiar o esforço de modernização da empresa brasileira, através da promoção da qualidade e produtividade, objetivando aumentar a competitividade dos bens e serviços produzidos no País". Houve uma definição programática da divisão do trabalho entre Estado e capital privado para o gerenciamento do programa:

O gerenciamento do Programa tem como pressuposto básico a atuação harmônica e coordenada do Estado, do empresariado, da classe trabalhadora e do consumidor. Ao Governo caberá os papéis de coordenador em nível estratégico e de articulador para a execução e avaliação dos resultados. A execução dos subprogramas e projetos será fortemente descentralizada, tendo no empresariado seu maior agente (BRASIL, Portaria MEFP n ${ }^{\circ}$ 365, de 26 de junho de 1990).

Assim, a liberalização da economia foi institucionalizada e, conforme a análise de M. A. C. Baptista (1993, p. 238), colocada como o "alicerce" da política industrial, ao identificar o protecionismo "como principal fator de inibição ao incremento da competitividade da indústria brasileira".

Também por meio de tais diretrizes, conformou-se a separação institucional das funções e atribuições do Estado e do Capital Privado (nacional e estrangeiro) como elemento primordial da política industrial. Mais ainda: o Estado, por meio de tais Diretrizes, passou à iniciativa privada o papel primordial na liderança do desenvolvimento produtivo nacional, ao capital estrangeiro o acesso à tecnologia e colocou a "grande empresa" como articuladora de pequenas e médias empresas, em uma clara relação de subordinação e dependência.

A abertura da economia passou a ser vista "como forma de induzir a modernização da indústria por parte do setor privado" (BAPTISTA, 1993, p. 238), relacionando-a diretamente a um possível aumento de competitividade do parque produtivo instalado no território nacional. Como forma de buscar acelerar o desenvolvimento industrial nacional, tentava-se ampliar a concorrência de empresas nacionais com empresas estrangeiras, junto da recuperação da tarifa 
como "instrumento básico da política industrial, ficando a proteção à indústria local restrita ao mix tarifa/câmbio"19 (BAPTISTA, 1993, p. 239 - grifo da autora).

Uma forte desvalorização da moeda nacional foi realizada à época buscando proteger, de alguma forma, a indústria nacional. Esse fator, junto da desestabilização nos mercados de consumo decorrente do descontrole inflacionário, da queda da produção industrial no país - por volta de 13\% entre 1990 e 1992, das políticas de arrocho salarial e da chamada "maxidesvalorização" da moeda em 1992 contribuíram para limitar o aumento da importação de produtos manufaturados no país (SOUZA, 2008).

Dessa maneira, mesmo que institucionalmente estivesse estabelecida uma ampla abertura de mercado, na prática, como notou N. A. de Souza (2008), esta abertura acabou sendo restrita. O que houve, de fato, foi um forte período recessivo, com um aumento de importações na ordem de 13\% em 1990 (no período do governo Sarney haviam aumentado cerca de 25\%), estacionando-se em 1991 e 1992. Os investimentos diretos estrangeiros passaram de 1,2\% em 1990 para 2,9\% em 1992, com participação de 6,1\% destes na aquisição de empresas nacionais em $1991^{20}$. Conforme concluiu o autor: "o governo Collor não conseguiu atrair o capital estrangeiro, mas assentou as bases para seu ingresso maciço no período posterior. Fez algo semelhante ao que fizera Eugênio Gudin quando ministro da fazenda no interregno de Café Filho" (SOUZA, 2008, p. 211).

Com a renúncia de F. Collor, assumiu a presidência, em outubro de 1992, Itamar Franco. Este estabeleceu no início de seu governo um afastamento dos ideais da ortodoxia econômica, definindo uma queda na taxa de juros e, com a concepção de que a inflação deveria ser combatia com desenvolvimento, buscou

\footnotetext{
${ }^{19}$ Sobre a questão tarifária, é preciso, igualmente, chamar a atenção para as diversas medidas tomadas visando a sua redução tais como: "concessão de isenção do IPI sobre bens de capital (produzidos localmente ou importados), a eliminação da exigência de financiamento externo para a importação de máquinas e equipamentos, a isenção de Imposto de Importação para máquinas, equipamentos, partes, peças e componentes, matérias-primas e produtos sem similar nacional e a redução do índice de nacionalização, para efeito de concessão do Finame de 85\% para 60\%” (BATISTA, 1993, p. 239 e 240).

${ }^{20}$ É importante notar, que, partindo de uma constatação a priori de "atraso tecnológico", a vinda de empresas estrangeiras era tida, pelo governo, como fator competitivo para a reestruturação da indústria nacional - como se, ao ser confrontada com situações de competição, as empresas nacionais tivessem como competir em mesmas condições com o capital estrangeiro. Esse processo foi estimulado por toda a década de 1990 .
} 
viabilizar o crescimento da produção e da economia do país ${ }^{21}$ com um movimento no sentido de voltar a ampliar os investimentos públicos e uma pequena, mas importante, reposição salarial. Essas medidas foram fundamentais para que se chegasse a um aumento do PIB do país na taxa de $4 \%$ e da produção industrial de 7\%, em 1993.

A partir desse ano, com a entrada de F. H. Cardoso no Ministério da Fazenda houve uma reestruturação das políticas e o Plano de Ação Imediata foi organizado e colocado em prática. Houve elevação da taxa de juros, volta de cortes nos "gastos públicos" federais, renegociação da dívida externa (e suspenção da moratória). Também houve uma maior abertura do mercado aos produtos estrangeiros, com a atração de investimentos externos e a valorização da moeda.

No ano seguinte, iniciou-se a implementação do Plano Real, com vistas a estabelecer uma nova moeda no país de modo a combater e controlar a inflação. Nesse momento, foi estabelecida a Unidade Real de Valor (URV) - responsável por converter os preços referenciados na moeda anterior para a nova, buscando-se com isso influir diretamente na determinação dos preços e salários por meio de uma taxa diretamente controlada pelo governo - e uma nova valorização da moeda nacional, admitindo uma flutuação cambial - controlada pelo Banco Central - com "teto máximo" em situações de paridade (do real em relação ao dólar).

No entanto, como os preços continuavam a subir, a saída adotada pelo governo foi a de maior liberalização comercial, buscando reduzir a inflação por meio de maior entrada de produtos estrangeiros baratos. Isso se deu com a valorização fixa - controlada pelo governo - do real em relação ao dólar, desde 1994. Essa medida, junto da referida redução das tarifas de importação e da

\footnotetext{
21 “A história de mais de uma década já havia revelado que a inflação brasileira não se podia domar com recessão. E isso por uma razão simples: sendo uma economia altamente concentrada, os grandes grupos econômicos reagiam à queda da demanda e, portanto, das vendas, não com a baixa dos preços, mas, ao contrário, com sua elevação. E podiam fazê-lo porque, além de seu poder sobre o mercado, contavam com uma economia de elevado grau de concentração de renda, o que permitia a existência de um elevado número de consumidores de altas rendas" (SOUZA, 2008, p. 218). É importante ressaltar que, além dessa questão relacionada à concentração econômica e sua capacidade de influir sobre os preços em todo o país, havia uma componente "inercial" na inflação, que se reproduzia da seguinte maneira: os preços anteriormente fixados serviam como base para novos e constantes reajustes, forçando os preços sempre para patamares mais altos. Como havia, segundo P. N. Batista Jr. (2001, p. 110), na economia brasileira "um amplo e complexo sistema de indexação, que abarcava a maior parte dos contratos e preços no país", esse efeito acabava sendo potencializado e fazia com que "o principal determinante da taxa de inflação corrente era a taxa de inflação no período imediatamente anterior".
} 
disponibilidade de capitais externos, passaram a ser utilizados como "instrumentos de combate às pressões inflacionárias" (BATISTA JR, 2001, p. 110).

Dessa maneira conseguiu-se, de fato, um controle da proporção do aumento dos preços no país ao mesmo tempo em que se garantia as condições para a volta e aumento do consumo. Como definiu P. N. Batista Jr. (2001, p. 110): "Por um lado essas decisões contribuíram para acelerar a queda da inflação. Por outro, logo produziram grandes desequilíbrios na balança comercial e no balanço de pagamentos em conta corrente".

Tornou-se difícil direcionar a política econômica no sentido do crescimento do país e da oferta de emprego, na medida em que,

apesar da queda da inflação, a economia não tem conseguido crescer de forma sustentada. Toda vez que a economia cresce um pouco mais rapidamente aparecem desequilíbrios preocupantes no balanço de pagamentos em conta corrente. Aumentou a dependência da economia brasileira em relação a capitais externos e a sua vulnerabilidade a oscilações de liquidez e do estado de ânimo nos mercados financeiros internacionais (BATISTA JR., 2001, p. 111).

Assim, com as políticas trazidas pelo Plano Real substituiu-se, do ponto de vista macroeconômico, a tendência inflacionária por uma componente estrutural de desequilíbrio interno e externo (BATISTA JR., 2001), com fortes consequências para as empresas nacionais durante toda a década de 1990.

A tendência de desequilíbrio estrutural, discutida anteriormente, estava fundada no baixo crescimento e na dependência de capitais externos, manifestandose tanto no aumento dos déficits em conta corrente (de 34,7\% em 1995 para 55,6\% em 1997), quanto na desestabilização das empresas nacionais. Com as condições favoráveis à entrada de capitais e produtos estrangeiros, as empresas nacionais não conseguiam oferecer produtos com a mesma competividade no mercado interno; e, por conta do baixo crescimento da economia e da taxa de câmbio desfavorável, não podiam obter receitas com a exportação para outros mercados.

Nesse contexto, ocorreu o aumento dos investimentos estrangeiros na formação socioespacial brasileira, incentivado pela política do já eleito governo $\mathrm{F}$. H. Cardoso (1995-2002), buscando: a) colocar um freio à degradação das contas nacionais, tornado "peça central do processo de financiamento das contas externas" (GONÇALVES, 1999, p. 77); b) promover o financiamento das contas 
públicas, arrecadando recursos junto a investidores estrangeiros por meio de privatizações e concessões; e c) tornar-se funcional ao crescimento da economia brasileira, sendo que a "aposta governamental é de que o capital estrangeiro promoveria o aumento da taxa de investimento da economia brasileira e, como resultado, o país teria maiores taxas de crescimento econômico" (GONÇALVES. 1999, p. 79).

Tais investimentos, durante o governo de F. H. Cardoso, elevaram-se extraordinariamente, ao ponto de R. Gonçalves $(1999$, p. 91) afirmar que o total de 45 bilhões de dólares acumulados entre 1996 e 1998 foi "maior do que todo o estoque acumulado durante toda a história da economia brasileira". Tais investimentos direcionaram-se, sobretudo, para a compra de empresas públicas (em diversas áreas, como eletricidade, rede ferroviária, telecomunicações) e para fusões e aquisições de empresas (indústrias e bancos) (GONÇALVES, 1999).

As indústrias, e em especial as pertencentes ao chamado complexo metal/mecânico, que tiveram seu comportamento afetado pelas "conjunturas e choques colocados pelas rápidas guinadas da política econômica" da década de 1980, sofreram, no início dos anos 90, um ajuste mais drástico, "quando a indústria é submetida ao ambiente competitivo internacional, numa conjuntura de recessão interna e depois de crescimento, mas com forte apreciação cambial" (PACHECO, 1998, p. 109 e 110).

Os investimentos estrangeiros nas indústrias se concentravam (79\% do total) em seis ramos: a automobilística, a química, a informática, a metalurgia básica, material eletrônico e de comunicações, produtos alimentícios e bebidas. No caso específico das indústrias de informática, a participação das empresas estrangeiras dentre o conjunto das empresas instaladas no Brasil passou de 69\% em 1994, para 78\% em 1995; em 1997 atingiu a marca de 81\% (GONÇALVES, 1999, p. 135), o que indicou um forte processo de desnacionalização do controle do setor na década de 1990.

Segundo W. Cano (1998) esse processo também teve fortes consequências regionais, com o período posterior a 1985 e sobretudo a partir da década de 1990 podendo ser caracterizado com uma inflexão no processo de desconcentração industrial - pelo menos na forma em que havia se realizado até então. Em paralelo 
à manutenção e aumento da participação industrial de São Paulo, houve redução pela metade na quantidade de empregos, junto da estagnação e até mesmo diminuição da participação nesse total da Zona Franca de Manaus (ZFM), entre 1990 e 1995; essa área dobrou os seus fluxos comerciais e aumentou sua produtividade por conta do aumento das importações. Para o autor, muitas indústrias eletrônicas e de informática tiveram como preferência locacional por São Paulo em detrimento da ZFM nesse período.

Outro fator importante a ser considerado no que diz respeito à indústria nesse subperíodo foi a estagnação do Nordeste, que perdeu dinamismo por conta da crise sofrida pela produção química, têxtil e de confecções no país; além disso, a estagnação de São Paulo reduziu as compras de insumos e matérias-primas desta região do país, o que agravou ainda mais seu desenvolvimento. Os demais estados e regiões tiveram crescimento relativo, seja por conseguirem atrair investimentos em ramos já existentes no país (caso de Minas Gerais e do Espírito Santo, com aumento de participação na indústria automobilística, material elétrico e comunicações), seja por apresentarem dinamismo próprio, como foi o caso da agroindústria no Centro-Oeste e o caso do Sul do país, que, além de sua indústria complexa e diversificada, possuía vantagens locacionais relativas à presença de mão de obra especializada e de sua posição geográfica próxima aos mercados do MERCOSUL (CANO, 1998).

Dessa maneira, com menores possibilidades de financiamento e maiores custos de produção, diversas empresas nacionais do circuito espacial de produção de ATMs também perderam dinamismo. Um exemplo foi o caso da Itautec que, entre 1997 e 1999, obteve prejuízos superiores a 100 milhões de reais em suas operações. Desde então, iniciou um processo interno de reestruturação concluído somente em 2005 - como será discutido no capítulo seguinte.

A esse respeito, a situação mais emblemática foi, certamente, o da empresa estatal Cobra - Computadores Brasileiros S.A. -, fundamental para o desenvolvimento das indústrias de informática e o estabelecimento de condições internas favoráveis à formação do circuito espacial de produção de ATMs em território nacional. Após acumular U\$ 146 milhões em prejuízos e com ampliação 
de sua crise com a abertura de mercado de 1992, em 1995, a empresa passou a ser controlada pelo Banco do Brasil.

Nesse processo, o banco assumiu 99\% da empresa; a sua dívida, de US\$ 25 milhões, foi transformada em capital de risco pelo banco e o seu quadro de funcionários foi reduzido de 751 para 452. Também foi definida, nesse momento, a mudança no seu perfil de negócios. Segundo L. Rodrigues (2001), "passou de desenvolvedora e fabricante para integradora de sistemas e, atualmente [2001], é conhecida como fornecedora de soluções tecnológicas para o mundo corporativo". Desta forma, conseguiu superar o déficit e, em 1997, passou a apresentar resultados positivos: faturamento de $\mathrm{R} \$ 142$ milhões e lucro $\mathrm{R} \$ 4$ milhões. Em 1998, ainda que com redução, continuou apresentando superávit, com receita de R\$134 milhões e lucro de R \$ 3,4 milhões.

A entrada da empresa estrangeira NCR no mercado nacional foi outro evento significativo, e representativo destas mudanças gerais da economia brasileiro. A empresa que até 1996 era parte da gigante das telecomunicações AT\&T, dos Estados Unidos, passou a atuar no mercado brasileiro em 1992, quando houve o fim da reserva de mercado para informática e desde então, passou a fornecer ATMs importados.

Outras empresas adotaram uma nova estratégia competitiva: a associação com grandes empresas estrangeiras. Esse foi o caso da Procomp, uma das primeiras empresas a estabelecer parceria com essas empresas (via joint ventures), reduzindo significativamente os custos de produção e forçando as empresas nacionais a constituir novas parcerias - caso da Itautec, Edisa e SID (PIRES, 1997; LEE, 2003).

Pode-se concordar, portanto, com M. Pochmann (2001, p. 39) quando afirmou que "o programa de liberalização produtiva, comercial, e tecnológica" representou a exposição de quase todo o sistema produtivo à competição internacional, cujos "resultados foram, na maior parte das vezes, negativos ao conjunto do país". 


\subsection{A reorganização dos círculos de cooperação no contexto neoliberal}

De forma sintética pode-se caracterizar a década de 1980 como uma das mais complexas da formação socioespacial brasileira, justamente por agregar, ao menos, quatro processos: i) processos de continuidade às políticas desenvolvimentistas do país, que se desdobravam desde a década de 1960, com o incentivo da substituição de importações (caso da Política de Informática, de 1984) e de desconcentração industrial; ii) uma intensa crise externa com fortes consequências internas e junto de uma crise interna (sobretudo relacionada à crise da dívida externa e à inflação) com fortes consequências para a integração do mercado nacional; iii) início de uma inflexão nos projetos nacionais desenvolvimentistas com a emergência de projetos liberais, por meio de inciativas que visavam à desestatização e de liberalização comercial; iv) a montagem de um Estado com características "sociais-democratas", com a criação do Ministério da Ciência e Tecnologia (1985) e a Constituição de 1988.

Durante esse período, a política informática e a institucionalização da reserva do mercado (em 1984) favoreceram tanto as indústrias de computadores, quanto as de eletrônica de consumo, privilegiando as empresas com capital nacional em detrimento do estrangeiro.

Dessa forma, no final dos anos 1980, houve um avanço do mercado de informática no país, com crescimento médio de 30\% entre 1986 e 1990, fazendo com que o Brasil aumentasse sua participação no valor total de produtos comercializados no mercado mundial de computadores e periféricos, passando de $0,65 \%$ em 1980 para 1,2\% em 1989. O controle à entrada de equipamentos estrangeiros, realizados pela Secretaria Especial de Informática, fez com que a participação das importações no faturamento das indústrias de computadores e periféricos caísse de 29,2\% em 1980, para 7,9\% em 1989 (FAJNZYLBER, 1993, p. $31)$.

No que diz respeito à participação do faturamento total das empresas nacionais no mercado nacional de computadores e periféricos, a mudança se comportou da seguinte maneira: se, em 1980, as empresas nacionais representavam 
$33 \%$ do total de faturamento no ramo, em 1986 passou para 58\%, mantendo-se até o final da década de 1980 a taxas superiores a 50\% (FAJNZYLBER, 1993, p. 32).

Dessa maneira, pode-se concordar com W. Cano (2000, p. 225), quando, ao estabelecer a relação entre políticas para a indústria e a ciência e tecnologia na década de 1980, asseverou:

as políticas de incentivo à industrialização e à ciência e tecnologia, a despeito da crise, não só foram mantidas como ampliadas, e estavam centradas em setores como biotecnologia, novos materiais e, principalmente, em informática e microeletrônica.

Nesse sentido, foi possível não apenas a ampliação da substituição de importações e aumento das exportações em um contexto de intensa crise, mas, igualmente, a proteção necessária para um "desenvolvimento tecnológico que garantisse maior incorporação soberana de ciência e tecnologia" (CANO, 2000, p. 225).

No entanto, quando se definiu pela guinada liberalizante, nos anos 1990, iniciou-se sob o governo Collor uma articulação política para buscar promover uma nova Lei de Informática em que fosse incorporada a revogação da reserva de mercado - que estava programada para estar vigente até 1992.

Em mensagem ao Congresso $\mathrm{Nacional}^{22}$, no ano de 1991, o governo argumentava a respeito dessa questão da seguinte maneira:

Em relação à política de informática, diversas medidas foram adotadas no sentido de compatibilizá-la com as «Diretrizes da Política Industrial e de Comércio Exterior». O Executivo enviou ao Congresso Nacional projeto de lei alterando a Lei $\mathrm{n}^{\circ} 7.232$, de 29 de outubro de 1984, bem como definiu uma lista de produtos de informática, considerados potencialmente competitivos, que receberão proteção até outubro de 1992. Da mesma maneira, estuda-se a revisão da Lei de Software, com o objetivo de retirar do texto legal exigências anacrônicas. Foram também facilitadas as associações de firmas nacionais com empresas estrangeiras detentoras de tecnologias mais avançadas.

Enquanto a nova Lei de Informática não era aprovada, o governo à época tomou uma importante iniciativa no sentido de desintegrar a articulação política com foco "nacionalista" e contrária à sua aprovação, com uma reforma

\footnotetext{
${ }^{22}$ Mensagem ao Congresso Nacional na abertura da 1" Sessão Legislativa Ordinária da 49? Legislatura. Brasília, Presidência da República, 1991. Disponível em: http://www.biblioteca.presidencia.gov.br/presidencia/ex-presidentes/fernando-collor/mensagens-aocongresso/mensagem-ao-congresso-nacional-na-abertura-da-primeira-sessao-legislativa-ordinaria-da-49alegislatura-1991/mensagem-ao-congresso-nacional-1991-parte-1
} 
administrativa que transformava a SEI, responsável até então por operacionalizar a reserva de mercado, em um Departamento de Política de Informática e Automação ligado à Secretaria de Ciência e Tecnologia, subordinando-a hierarquicamente (LEE, 2003).

Em 1992, a mensagem do representante do Executivo ao Congresso Nacional $^{23}$ transparece o avanço na articulação em direção à aprovação de uma nova Lei de Informática e já aparecia a referência explícita ao fim da reserva de mercado:

Quanto à política de informática, diversos aspectos e instrumentos da política setorial tem sido analisados pelo Congresso Nacional visando a institucionalizar as novas diretrizes estabelecidas para o desenvolvimento do setor. Merecem ênfase a elaboração do II Plano Nacional de Informática (II PLANIN) com a aprovação da Lei de Informática, que prevê o fim da reserva de mercado para o setor em 29 de outubro de 1992.

Com a aprovação da Lei $\mathrm{n}^{\circ}$ 8248, em 1991, a reserva de mercado foi de fato destituída da política de informática, significando, segundo M. J. Lee (2003, p. 126), "a retirada do mecanismo regulador governamental em relação à comercialização, às fontes de tecnologia e à fabricação de equipamentos de processamento de dados".

Também houve, por assim dizer, a introdução de "mecanismos políticos alternativos", tais como o incentivo fiscal às empresas que investiam ao menos $5 \%$ do seu faturamento em atividades de Pesquisa e Desenvolvimento (P\&D), isenção sobre IPI para a aquisição de bens de capital (M. J. LEE, 2003, p. 127). Assim,

A abertura do mercado interno e a diminuição do controle do governo na economia representaram uma perda das próprias funções do governo. Restou-lhe apenas uma política coordenativa para potencializar as vantagens já existentes na indústria de TI como um todo (M. J. LEE, 2003, p. 128)

Enquanto que as políticas de Estado deixaram de ter a função de catalisadora da relação entre bancos e indústrias de alta tecnologia, a Febraban ampliou sua participação nos círculos de cooperação das empresas ligadas ao circuito espacial de produção de ATMs.

\footnotetext{
${ }^{23}$ Mensagem ao Congresso Nacional na abertura da 2* Sessão Legislativa Ordinária da 49" legislatura. Brasília, Presidência da República, $1992 . \quad$ Disponível http://www.biblioteca.presidencia.gov.br/presidencia/ex-presidentes/fernando-collor/mensagens-aocongresso/mensagem-ao-congresso-nacional-na-abertura-da-segunda-sessao-legislativa-ordinaria-da-49alegislatura-1992/mensagem-ao-congresso-nacional-1992-parte-1
} 


\section{A crescente importância da Febraban: a atuação do Centro Nacional de Automação Bancária (CNAB) e o Congresso Internacional de Automação Bancária - CIAB/FEBRABAN}

A partir das discussões realizadas no Centro Nacional de Automação Bancária (CNAB) durante o ano de 1989, em 1990 foi aprovada pela Febraban a realização do I Congresso Internacional de Automação Bancária (CIAB/FEBRABAN) em 1991. Nesse primeiro momento, o evento contou poucas empresas e bancos expondo seus produtos, mas pouco a pouco o evento foi ganhando proporções maiores. Como destacou, W. Gutierrez ${ }^{24}$ (2010, p. 353) em depoimento:

Como tudo, esse primeiro congresso nasceu pequeno, mas rapidamente conseguiu colocar no mercado uma imagem nova de como um evento deveria ser constituído. Nós apresentávamos palestras e necessidades do sistema financeiro. E as empresas, então, apresentavam seus produtos.

Destaca-se ainda, em seu depoimento, a forma com que se viam as mudanças ocorridas no sistema político e as necessidades a serem debatidas entre empresas e bancos comerciais. É possível perceber a grande importância que teve para os bancos comerciais o investimento em tecnologia da informação para buscar obter maior controle e ganhos da inflação à época:

O grande desafio que se apresentou para o Ciab foi ser o primeiro grande evento dedicado à tecnologia para o sistema financeiro. Foi um período de conquistar um espaço para falar dos problemas de tecnologia bancária para o sistema. Nesse momento estávamos passando de 107 para 220 bancos devido à Constituição de 1988, que permitiu a criação de bancos múltiplos. E devido aos planos econômicos, houve a necessidade de uso intenso da tecnologia. Durante o período de inflação, a agilidade era fundamental, sem isso não era possível fazer as aplicações que o sistema exigia e rodar durante a noite as informações de tudo o que aconteceu no sistema financeiro e bancário.

O Ciab veio colocar isso de forma que toda a população e o mercado, e também os fornecedores de equipamentos e de soluções de software, passassem a conhecer as necessidades dos bancos (GUTIERREZ, 2010, p. 353-354)

Dessa maneira, o evento tornou-se, durante toda a década de 1990, importantíssimo para fazer a articulação entre empresas e bancos comerciais (públicos e privados), promovendo discussões entorno de diversos temas gerais de

\footnotetext{
${ }^{24}$ Wilson Gutierrez foi um importante executivo ligado sistema bancário brasileiro, atuando entre $1958 \mathrm{e}$ 1990 em diversos bancos comerciais, incluindo o Bradesco e o Unibanco. Entre 1986 e 1990 foi o presidente do Centro Nacional de Automação Bancária e responsável por aprovar a realização e contribuir para a organização do I CIAB/FEBRABAN.
} 
interesse e de tendências de produção e uso dos objetos técnicos ligados à automação bancária.

Como pode ser visto no quadro síntese a seguir (Quadro 4), o Congresso reuniu diferentes empresas e tem facilitado tanto a exposição de estratégias frente aos novos cenários que as firmas se defrontavam, como também a discussão junto aos bancos e profissionais de diversas áreas sobre novos produtos, serviços e estratégias de automação.

Quadro 4 - Quadro síntese dos temas e questões discutidas nos Congressos Internacionais de Automação Bancária (CIAB-FEBRABAN) entre 1991 e 1999, por ano

\begin{tabular}{|c|c|}
\hline Ano & Principais questões discutidas no evento \\
\hline 1991 & $\begin{array}{l}\text { "Foram expostas novidades do setor à época, como impressoras de cheques } \\
\text { personalizados e impressoras a laser e micro filmadoras" }\end{array}$ \\
\hline 1992 & $\begin{array}{l}\text { "Ano marcou a popularização dos serviços pelo telefone. Nessa edição do } \\
\text { Ciab/FEBRABAN, os investimentos em multimídia, processamento de } \\
\text { imagens e redes de comunicação de dados mais eficientes começaram a se } \\
\text { aquecer após um período de adiamento de investimento por parte dos } \\
\text { bancos devido à incerteza de mudanças na política de informática do } \\
\text { governo." }\end{array}$ \\
\hline 1993 & $\begin{array}{l}\text { "evento tratou de temas como a melhoria do atendimento, massificação do } \\
\text { autoatendimento, a conquista de grande poder de processamento e } \\
\text { informações rápidas para ajudar o cliente na tomada de decisão." }\end{array}$ \\
\hline 1994 & $\begin{array}{l}\text { "apresentou produtos que mostraram a preocupação das instituições } \\
\text { financeiras com a melhoria dos processos. Bancos queriam oferecer uma } \\
\text { alternativa para que o cliente não tivesse a obrigação de frequentar as } \\
\begin{array}{l}\text { agências, } \\
\text { fácil aprendizado" }\end{array} \\
\text { o }\end{array}$ \\
\hline 1995 & $\begin{array}{l}\text { "As novas exigências do mercado globalizado geraram demanda para } \\
\text { produtos eletrônicos ágeis e seguros" }\end{array}$ \\
\hline 1996 & $\begin{array}{l}\text { "focou temas relacionados a banco virtual, smart card, dinheiro eletrônico, } \\
\text { internet e o desafio do ano } 2000 \text {. Levantamento realizado pela Procomp } \\
\text { mostrou que } 22 \% \text { do mercado de informática brasileiro era movimento pelos } \\
\text { investimentos vindos do setor financeiro (US } \$ 2 \text { bilhões)." }\end{array}$ \\
\hline 1997 & $\begin{array}{l}\text { "palestras e produtos que envolviam sistemas para auxiliar o } \\
\text { desenvolvimento de canais remotos, banco via internet e soluções voltadas } \\
\text { ao comércio e novos equipamentos de autoatendimento" }\end{array}$ \\
\hline 1998 & $\begin{array}{l}\text { "Assuntos como a simulação de processos de decisões de negócios, } \\
\text { tendências do serviço financeiro e o efeito da internet nas transações } \\
\text { bancárias estiveram no centro dos debates" }\end{array}$ \\
\hline 1999 & $\begin{array}{l}\text { "soluções para serviços online financeiros, online trading, call center, } \\
\text { business intelligence, aplicações direcionadas para corretoras e distribuidoras } \\
\text { de títulos e valores mobiliários" }\end{array}$ \\
\hline
\end{tabular}

Fonte: Mompean, A. "Ciab-FEBRABAN: 25 anos promovendo a tecnologia nos bancos". Revista Ciab Febraban, no 56 , abril/2015. pp. 15-19. 
É possível observar que a partir de 1993 a questão do autoatendimento passou a ser discutida com maior ênfase, denotando um maior foco para produção e consumo destes objetos técnicos. E, a partir de 1997, os bancos começaram a discutir a questão da internet e como isso poderia afetar a sua oferta de produtos e serviços financeiros.

Um ponto importante que deve ser destacado é que essa crescente importância dos Congressos já havia sido notada por J. Labasse (1984, p. 687), para quem, mesmo que "os meios de transmissão simultânea de imagem e som, teletexto, fax, vídeo telefonia, etc., multiplicam-se, nunca foram tão importantes as necessidades de reuniões diretas" ${ }^{25}$.

Segundo esse autor, haveriam diversos fatores que "influenciam o comportamento dos encontros internacionais em um país" (LABASSE, 1984, p. 690):

- "o nível de desenvolvimento, especialmente do ponto de vista das indústrias de pesquisa e de ponta";

- "o número de representantes de organizações internacionais que são susceptíveis de convidar e organizar num congresso";

- "sua imagem, feita pela sua capacidade de acomodação e qualidade de seus equipamentos e serviços especializados na organização e realização de conferências"26.

Como ressalta o autor, além dessas condições de desenvolvimento de um país, deve-se atender internamente ao Estado, ainda "as condições de hospitalidade exigidas por clientela internacional (segurança, tradição cultural, facilidade de troca monetária)" (LABASSE, 1984, p. 691), abrindo-se margem para uma concorrência essencialmente entre as metrópoles.

\footnotetext{
25 Tradução própria do excerto:"Alors que les moyens de transmission simultanée de l'image et du son, vidéotexte, télécopieur, visiophonie, etc., se multiplient, jamais les besoins de rencontre directe n'ont été aussi importants" (LABASSE, 1984, p. 687).

${ }^{26}$ Tradução própria do excerto: "Plusieurs facteurs influencent la tenue des réunions internationales dans un pays:

- son niveau de développement, surtout du point de vue de la recherche et des industries de pointe;

- le nombre de représentants d'organisations internationales qui sont susceptibles d'inviter et d'organiser un congrès;

- son image, faite à la fois de sa capacité d'hébergement et de la qualité de ses équipements et services spécialisés dans l'organisation et l'accueil des congrès" (LABASSE, 1984, p. 690).
} 
Para J. Labasse (1984, p. 696) esses congressos, até mesmo os internacionais, são "uma grande oportunidade para os fabricantes locais para mostrar o seu equipamento e fazer contatos", o que ajudaria ao participante "tirar proveito de uma reunião para estabelecer laços, assinar acordos de licenciamento ou de associação ou de decidir criar uma subsidiária"27.

Dessa forma, Congresso Internacional de Automação Bancária (CIAB/FEBRABAN), ao promover o encontro entre inúmeros agentes públicos e privados, nacionais e estrangeiros, ligados aos bancos, empresas de tecnologia e empresas produtoras de ATMs em São Paulo, contribui fortemente para fortalecer e articular as empresas do circuito espacial de produção de ATMs no Brasil - e constituindo-se, portanto, em um poderoso elemento do círculo de cooperação deste circuito.

\subsection{Os ATMs e as mudanças na circulação da informação bancária no Brasil dos 1990}

Conforme mencionado, durante toda a década a 1970 foi executado, pelos governos militares, um projeto de modernização e integração territorial, pautado, em grande medida, na expansão e densificação das redes de circulação material e informacional do território brasileiro. Segundo M. Santos e M. L. Silveira (2001, p. 73) o desenvolvimento das telecomunicações no Brasil foi um "marco no processo de reticulação do território", na medida em que participou "rigorosamente do jogo entre separação material das atividades e unificação organizacional dos comandos".

Outro marco desse projeto territorial para a formação socioespacial brasileira foi a Reforma Bancária de 1964/1965, que fomentou na década de 1970 um intenso processo de concentração bancária. É fundamental ressaltar que, entre 1966 e 1972, houve 162 incorporações e 23 fusões de bancos; e, entre 1962 e 1972, uma expansão de $40 \%$ no número de agências instaladas, sendo que a maior parte destas (71,6\%), em 1972, pertenciam aos bancos privados (SANTOS \& SILVEIRA, 2001).

\footnotetext{
27 Tradução própria do excerto: "Même internationale, c'est une excellente occasion, pour les industriels locaux, de montrer leur matériel et de prendre des contacts. Un participant peut également profiter d'une réunion pour nouer des liens, signer des accords de licence ou d'association ou décider la création d'une filiale" (LABASSE, 1984, p. 696).
} 
Já entre 1972 e 1996, com a consolidação das redes bancárias nacionais, com as novas condições políticas dadas pela extinção das cartas-patentes, a partir da chamada "Minirreforma Bancária" de 1988, houve uma expansão de 110\% no número de agências dos bancos, de instituições públicas e privadas: em 1972, haviam 7.712 agências, enquanto que, em 1996, haviam 16.224 (SANTOS \& SILVEIRA, 2001).

Esse processo influenciou não apenas a referida fragmentação e separação espacial das atividades bancárias, como também representou, para os bancos, um intenso processo de readequação dos seus sistemas técnicos, por meio da automação e da incorporação de objetos técnicos, transformando, inclusive, quantitativa e qualitativamente os seus fluxos financeiros e informacionais.

Entre 1964 e 1973, segundo análise de H. Pires (1995, p. 152-154) os fluxos financeiros se davam segundo uma "a gestão centralizada baseada numa forte concentração territorial dos fluxos financeiros e na ampliação na escala de atuação". Esses movimentos dependiam ainda de duas outras questões: a) das características das transações à época, cujas "informações e decisões eram centralizadas em grandes centros de processamento de dados (CPDs), interligados pela rede nacional de telex (RNTx)"; e b) da característica do processo de automação bancária até então, que era "constituída pelo uso crescente de CPDs e pela ampliação das redes de comunicação por telex".

De 1974 a 1986, com a ampliação da concentração bancária e da dispersão das agências, a circulação de informações se intensificou e passou a ocorrer a partir da "gestão descentralizada assentada na territorialização da automação bancária dos fluxos financeiros, na segmentação, na integração vertical e na continuação da ampliação da escala de atuação" (PIRES, 1995, p. 152-153). Nesse momento, segundo H. Pires (1995, p. 153) a operacionalização das transações se deu a partir do processamento de dados distribuídos "compartilhados regionalmente por minicomputadores, automatic teller machines (ATMs) e terminais de transferências de fundos (TTFs), interligados por telex, hipertexto e satélite". Também foi importante o desdobramento do processo de automação bancária, com a "implantação e difusão de ATMs, TTFs e surgimento dos serviços dos Bancos: Instantâneo, Eletrônico, Interlig, 24 Horas" (PIRES, 1995, p. 154). 
Já entre 1987 e 1993, os fluxos financeiros passaram a se dar por meio da "gestão instantânea desenvolvida a partir do processo de reestruturação territorial dos fluxos e das operações financeiras, efetuado através da desintegração vertical, da diferenciação e da ampliação do escopo de atuação das atividades" (PIRES, 1995, p. 153). As transações passaram a ocorrer com o tratamento informacional "instantaneamente, em tempo real, via on line, em várias redes locais integradas por supercomputadores e microcomputadores, telefones, faxs/modens, ATMs, TTFs, interligados por satélites". Já os processos de automação se deram pela "informatização, pela terciarização acelerada e pelo crescimento em reestruturações inovativas e em novas tecnologias digitais" (PIRES, 1995, p. 154).

É justamente a partir das incorporações progressivas dessas novas formasconteúdo, das economias de escala trazidas por esse processo de concentração econômica, da ampliação dos volumes dos fluxos e das novas qualidades das redessuporte de telecomunicações na formação socioespacial brasileira que se pode apreender a estruturação e as qualidades informacionais dessas redes-serviços de operações e transações financeiras.

Esse processo expansivo do sistema bancário na formação socioespacial brasileira foi calcado não apenas nos ganhos advindos de serviços financeiros diretamente a clientes, mas também em ganhos no mercado financeiro e em lucros inflacionários. A desestabilização macroeconômica do país, durante toda a década de 1980 levou a um período de hiperinflação, cujos efeitos se fizeram sentir ainda na década de 1990. Apesar das medidas de combate à inflação do governo Collor ${ }^{28}$, esta permaneceu elevadíssima, com valores médios de 1.782,9\% para 1989, $1.476,6 \%$ em 1990, 480,2\% em 1991 e 1.157,9\% em 1992. Apenas em 1993, com a

\footnotetext{
${ }^{28}$ Destacam-se, entre essas medidas: o bloqueio de ativos financeiros (incluindo tanto os vinculados a títulos públicos, como a poupança popular), a prática de juros reais negativas em 1990, medidas de arrocho salarial, cortes de "gastos públicos", e, a partir de 1991, congelamento de preços, revogação de subsídios, corte de despesas e custeio de estatais, aumento do imposto e das tarifas e a redução drástica de tarifas de importação. Tais medidas, além de acabarem tendo um impacto recessivo na economia, não foram capazes de conter a inflação na medida em que, com a redução da demanda, com a desestabilização monetária e com a desarticulação do mercado interno houve uma limitação da presença de produtos importados no período, favorecendo aos grandes grupos empresariais nacionais enfrentar o governo e definir os preços "para cima". Outro fator que contribuiu para o descontrole inflacionário nesse momento foi a substituição dos "indexadores oficiais" ligados ao Bônus do Tesouro Nacional (BTN), controlado pelo governo, pela Taxa Referência, que passou a ser calculada pelo Banco Central com base em amostras de taxas dos Certificados de Depósito Bancário (CDBs) praticadas pelos bancos comerciais para captação de recursos - o que favoreceu aos bancos estabelecerem as taxas que bem entendessem (SOUZA, 2008).
} 
inflação de $2.700 \%$, os bancos instalados no Brasil auferiram rendimentos com floating (o "lucro" gerado pela inflação) na ordem de 9 bilhões de dólares ${ }^{29}$.

A instituição do Plano Real pode ser considerada com um evento significativo desse processo, pois permitiu uma estabilidade macroeconômica para o controle da inflação e, junto de outras medidas, criou uma nova lógica de funcionamento para todo o sistema financeiro nacional. A progressiva queda da inflação registrada a partir de 1994, por um lado, reduziu rapidamente os lucros inflacionários dos bancos no país: de um lucro que fora de R\$ 9 bilhões em 1993 para aproximadamente $\mathrm{R} \$ 464$ milhões em 1994. Por outro lado, o progressivo endividamento interno do setor público, junto de altas taxas de juros e da sobrevalorização da moeda atraiu diversos "investimentos" em títulos da dívida pública federal, remunerando os compradores desses títulos a valores muito acima dos praticados em outros países.

Nesse contexto, os bancos que ainda se aproveitavam dos lucros inflacionários de fins da década de 1980 e início dos 1990 tiveram que se adaptar às novas condições, seja por meio de uma busca por maior produtividade da intermediação financeira, prestação de serviços e cobranças de tarifas (LARANGEIRA; FERREIRA, 2000), seja por se aproveitarem da implantação de novas técnicas, de conteúdos normativos, ou, ainda, das novas condições urbanoregionais, como pode ser visto no Quadro 5.

\section{Quadro 5 - Anos 1990: Condições para a ação dos bancos na formação socioespacial brasileira}

\begin{tabular}{cl}
\hline Condições & $\begin{array}{l}\text { Controle inflacionário e fim do floating } \\
\text { Endividamento do setor público } \\
\text { Macroeconômicas } \\
\text { Plano Real: estabilização da moeda e expansão do consumo } \\
\text { Nova concentração bancária }\end{array}$ \\
\hline $\begin{array}{c}\text { Condições Político- } \\
\text { Normativas }\end{array}$ & $\begin{array}{l}\text { Mudanças na legislação, dando maior flexibilidade para entrada de } \\
\text { instituições financeiras estrangeiras } \\
\text { Implantação do PROER e do PROES }\end{array}$ \\
\hline Condições Técnicas & Internet \\
& $\begin{array}{l}\text { Harwdares e softwares com maiores velocidades de processamento de dados } \\
\text { Expansão das Redes de Fibra Óptica }\end{array}$ \\
\hline Condições Urbano- & $\begin{array}{l}\text { Processo de Metropolização-Periferização } \\
\text { Presença desigual do meio técnico-científico-informacional } \\
\text { Regionais }\end{array}$ \\
\hline
\end{tabular}

Fonte: Elaboração Própria.

${ }^{29}$ A estimativa foi veiculada na Revista Exame de 1 de junho de 1996 em citação da fala do presidente do Banco Central à época, Gustavo Loyola. 
Como argumentaram também M. C. Tavares e J. C. Miranda (1999, p. 346), muitos bancos não conseguiram se adaptar às novas realidades dos anos 1990, o que, além de evidenciar o "descasamento entre ativos e passivos, explicam a fragilidade financeira de alguns dos maiores bancos nacionais (Nacional, Econômico e Bamerindus)". Dessa forma, tal processo resultou em novas fusões e aquisições (entre 1991 e 1997, 59 instituições financeiras privadas nacionais foram vendidas), ou seja, em uma maior velocidade no processo de centralização e concentração dos capitais bancários (TAVARES \& MIRANDA, 1999).

Vale ressaltar a importância, neste contexto, dos já mencionados Programa de Estímulo à Reestruturação do Sistema Financeiro Nacional (PROER, de 1995) e Programa de Incentivo à Redução do Setor Público Estadual na Atividade Bancária (PROES, de 1996), que significaram uma nova forma de atuação do Estado e de organização da atividade bancária no país. O primeiro Programa foi a base legal para a privatização de bancos públicos, enquanto o segundo catalisou a entrada de bancos estrangeiros no Sistema Financeiro Nacional.

A privatização de bancos públicos estaduais reduziu a participação das instituições públicas no total do patrimônio líquido bancário nacional de 36,25\% em 1995, para 16,28\% em 2002. Ao se comparar este dado com o aumento relativo do patrimônio líquido dos bancos estrangeiros observa-se uma inversão considerável, na medida em que passaram de 13,08\%, em 1995, para 32,89\% em 2002. Esta inversão é reforçada pelo comportamento estável das instituições privadas nacionais, que passaram de 49,21\% da participação no patrimônio líquido bancário em 1995, para 48,66\% em 2002 (NAKATANI \& SABADINI, 2010) ${ }^{30}$.

\footnotetext{
${ }^{30}$ Nesse caso, se faz possível afirmar que tais processos significaram, igualmente, uma privatização e internacionalização das informações sobre as populações e empresas presentes no território nacional. Essa ideia supracitada é reforçada por J. Stiglitz e B. Greenwald (2004: 322) quando, tratando acerca da liberalização do mercado de serviços financeiros, asseveraram que uma das vantagens da entrada de instituições estrangeiras de crédito é que estas "podem fazer uso da experiência estrangeira para proporcionar crédito com mais eficiência e eficácia". Mas, quanto às desvantagens, argumentaram que "a base de informações dos estrangeiros é com freqüência bem mais fraca, pelo menos em relação a pequenas e médias empresas, do que a dos bancos domésticos". Em outro momento, esses autores foram ainda mais enfáticos: "empréstimos estrangeiros e empréstimos domésticos não são substitutos perfeitos, uma vez que os dois grupos de instituições têm bases de informações diferentes e, portanto, tendem a emprestar para tipos diferentes de empresas. É possível que as empresas domésticas fiquem em pior situação, mesmo que os empréstimos totais aumentem (STIGLITZ; GREENWALD, 2004: 324 - grifo dos autores). Pode-se ir ainda mais longe e pensar que essa reordenação dos patrimônios monetários e informacionais implicaram em uma reafirmação e aprofundamento de uma estrutura desigual de poder no território nacional, com reforço da primazia e da situação de centro de gestão intermediário de bancos
} 
Nesse período houve o início do uso da internet no Brasil e da expansão das infraestruturas de fibra óptica. Por serem parte de uma nova rede-suporte de telecomunicações, como explicou B. Warf (2013, p. 9), satélites e fibras ópticas formam as tecnologias "primárias" da "indústria global de telecomunicações, incluindo a internet". Os cabos de fibra óptica oferecem a vantagem às grandes corporações, "para transmissão de dados" e às instituições financeiras "para os sistemas de transferência eletrônica de fundos, em parte porque esses meios oferecem elevados graus de segurança e redundância" (WARF, 2013, p. 9). Ainda para o autor,

A rede de linhas de fibra óptica ligando o mundo constitui o sistema nervoso do sistema financeiro e da economia dos serviços globais, ligando cidades, mercados, fornecedores e clientes ao redor do mundo global e o backbone de tráfego de internet (WARF, 2013, p. 12).

No Brasil, como explicaram M. Santos e M. L. Silveira (2001, p. 80) a extensão das redes de fibras ópticas se deu em duas direções: uma externa, conectando suas localidades a outros países, com a incorporação dos "cabos de fibras ópticas Unisur (une Porto Alegre ao resto do Brasil e à Argentina e ao Uruguai), o Américas I (Fortaleza à Venezuela, Caribe e Estados Unidos) e o Colombus II (Fortaleza a México, Estados Unidos e Europa)" e outra interna, interligando a rede urbana nacional com a criação da Rede Nacional de Fibras Ópticas, que "comunica Fortaleza a Porto Alegre, as capitais dos Estados e outras cidades litorâneas", da qual excetuava-se um cabo específico que "vai do Rio do Janeiro a Belo Horizonte, Brasília e Goiânia".

Já a internet expandiu-se no país a partir de 1995, por meio de "suportes materiais e solidários" - satélites, fibra óptica, rede telefônica e computadores -, em um processo "comandado pela Embratel e pela Rede Nacional de Pesquisa (RNP), que compreendem um backbone, ou conjunto de circuitos de transmissão de abrangência internacional e nacional" (SANTOS \& SILVEIRA, 2001, p. 85).

A RNP era tida como "uma espinha dorsal - um backbone - de abrangência nacional, que liga universidade e centro de pesquisa do país à Internet", enquanto que, segundo M. Santos e M. L. Silveira (2001, p. 85), como parte complementar 
desse "novo sistema técnico", situavam-se os provedores de acesso "que possibilitam a conexão do equipamento informático dos usuários com rede, e os provedores de informações". Tais provedores, todavia, revelavam as novas desigualdades na formação socioespacial brasileira, na medida em que

Dos 446 provedores de acesso à Internet, em 1996, 231 deles $(51,8 \%)$ concentravam-se na região Sudeste, mas fundamentalmente em São Paulo (124), no Rio de Janeiro (57) e em Minas Gerais (42), e 19,7\% na região Sul. E o número de usuários da Internet passou de 250 mil em 1995 para 2,2 milhões três anos depois (SANTOS \& SILVEIRA, 2001, p. 85).

Esse é um ponto fundamental das redes-suporte presentes no território brasileiro nesse subperíodo: às redes de fibra óptica complementavam-se os satélites, que, como recordou R. Castillo (1999, p. 123) já haviam nascido "compondo os sistemas técnicos precedentes, articulando-se com outros objetos técnicos na unificação do planeta". Esse autor lembra ainda que, quanto maior os limites oferecidos pelo planeta, maior a tendência de crescimento do uso e da quantidade de objetos técnicos "inteligentes", o que contribuiria para adensar as redes e as inter-relações. Esse era o caso dos satélites que, entre suas possibilidades, permitia a integração eletrônica do território "a despeito de qualquer dificuldade de ordem fisiográfica ou de desigualdades de distribuição de infraestruturas" (CASTILLO, 1999, p. 124).

O entendimento dessas especificidades e das novas desigualdades mencionadas são fundamentais para a compreensão da situação de complementaridade entre as redes-suporte para comunicação de dados na formação socioespacial brasileira: enquanto as redes de fibra óptica eram mais densas na porção leste e sul do território brasileiro e menos densas na região Norte e CentroOeste, as comunicações por satélite e por micro-ondas eram privilegiadas nessas últimas (CASTILLO, 1999). Nas redes bancárias, por conta da escala de abrangência de seus serviços, essas diferenciações também se manifestavam na organização, realização e gestão dos fluxos informacionais, refletindo, inclusive na possibilidade de uso da internet e da automação completa das redes, que ainda não havia sido realizada.

A internet pode ser entendida, ainda, segundo E. Diniz (2000, p. 8), como "um conjunto de diferentes redes de computadores, interconectadas através de um protocolo de comunicação comum, o TCP/IP (Transfer Control Protocol/lntemet 
Protocol)", fato este que permitiria a usuários "se comunicar, trocar arquivos e compartilhar recursos computacionais disponíveis em redes distintas daquelas nas quais eles próprios estão diretamente conectados".

Nesse sentido, para que pudesse ser utilizada em operações de serviços financeiros, além da necessária instalação e expansão das redes-suportes mencionadas anteriormente, deveriam ser garantidos, pelo menos, quatro requisitos adicionais (DINIZ, 2000, p. 26): a) integridade (sintetizada na frase "os dados devem chegar intactos"); b) confiabilidade ("ninguém, a não ser o destinatário, pode ter acesso aos dados transmitidos"; c) autenticação ("garantir a responsabilidade pelo envio dos dados"; e d) não-repudiabilidade ("nenhuma das partes envolvidas pode negar que ocorreu a transação").

Dessa forma, sua incorporação nas redes bancárias demandou um intenso trabalho de readequação. No caso do Bradesco, por exemplo, segundo F. Viana (2012, p. 88) a integração à internet começou a ser feita um ano antes, em 1994, quando as equipes da empresa Scopus trabalharam em conjunto os funcionários da instituição para garantir que consultas de saldos e extratos pudessem ser feitas até que se chegasse à oferta completa de serviços pela internet em 1996. Isso fez com que os funcionários dos caixas não precisassem mais "tomar notas" das operações efetuadas, com os computadores das agências sendo utilizados para efetuar os registros e para transmiti-los de forma instantânea para os servidores de grande porte. Esse foi um processo que se deu também nas demais instituições financeiras integradas à "web", como explicou I. Ângelo (2007, p. 170): "Servidores e provedores se posicionaram e dividiram o mercado. Os maiores bancos lançaram serviços on-line a partir de 1996, e então se fez o salto tecnológico para a internet banking - o banco pela Internet".

Houve a diminuição da necessidade de trabalho na "retaguarda" das agências, isto é, as atividades de suporte voltadas para a contabilidade e registro da informação dos papéis para os computadores centrais. Segundo N. Jinkings (2000, p. 104),

Com o sistema on-line o caixa bancário passava a ter acesso aos dados necessários à execução de suas tarefas diretamente no terminal do computador, que lhe servia de instrumento de trabalho. Ao mesmo tempo, passava a executar, no próprio guichê, um conjunto de tarefas antes realizadas na 'retaguarda' do atendimento. 
Como as redes-suporte difundidas a partir da década de 1990 facilitavam o deslocamento em tempo real de dados (principalmente aqueles ligadas ao funcionamento da internet, redes de fibra ópticas e satélites) e como houve uma modernização na capacidade de armazenamento e processamento dos hardwares e softwares existentes, tornou-se possível reorganizar e requalificar os antigos Centros de Processamento de Dados. Desse processo, que durou até o fim dos anos 1990 e início dos anos 2000, emergiram os Data Centers (DC) - "centro de dados", em tradução literal.

Isso porque, ao contrário dos $\mathrm{CPDs}$ que demandavam uma quantidade enorme de trabalho humano para digitar as informações das agências e retransmitilas para os fixos das redes bancárias, tornou-se possível armazenar, processar e retransmitir as informações predominantemente por computadores, servidores e periféricos, enquanto que as equipes de tecnologia do banco voltaram-se para o aprimoramento de rotinas de software e de reparos de equipamentos ou problemas de conexão.

No caso do Bradesco, em 1996 já havia sido realizada, segundo C. Gomes (2001), uma grande mudança, com a construção de um novo DC em Alphaville, interligado por rede de fibra óptica ao de Osasco, representando uma estrutura

capaz de executar cerca de quatro dezenas de milhões de transações ao dia, por meio de seus 2116 profissionais de informática, seus 120 servidores e 6 mainframes, seus 35 mil micros e 34650 deles em rede, com suas agências interligadas via rede de pacotes ou via satélite (GOMES, 2001, p. 268)

Segundo a autora, processos semelhantes ocorreram no Itaú, no Banco Real, no Banco 24 horas e no Citibank (GOMES, 2001). Junto desse processo, houve a diversificação de produtos e de soluções oferecidos dos bancos, conforme destacou H. Pires (1997, p. 13-14):

O uso do sistema de código de barras nos cheques e de cartões magnéticos também eliminou inúmeras antigas funções bancárias. As informações e decisões passaram a ser tratadas instantaneamente em tempo real, via on line, em várias redes locais integradas por servidores e microcomputadores, telefones, faxs/modens, ATMs, TTFs, interligados por satélites.

De tal modo, como foi apontado por S. Larangeira e V. Ferreira (2000), a descentralização do atendimento ao cliente, a ampliação da cadeia de produtos através da automação e a flexibilidade de certos serviços de atendimento ao cliente 
foram vistos, nesse momento, como estratégias competitivas. O uso de terminais de autoatendimento aumentou enormemente nesse período, passando de cerca de 3.000 unidades em 1994, para 53.000 no ano seguinte.

Assim, estendida não apenas para o processamento da informação, como também para a entrada de dados através dos canais de atendimento e implantação de sistemas online (manutenção da acessibilidade) e em tempo real (comunicação de dados), a automação favoreceu a transmissão de informações em tempo real, e a troca de dados em rede entre computadores centrais dos bancos e as diversas agências (e também entre elas próprias).

Com esses novos conteúdos, o sistema bancário pôde reduzir as necessidades do que M. Dantas (2003, p. 20) caracterizou como "economias de velocidade": o barateamento do custo de transações mediante a concentração de "recursos humanos e materiais no menor espaço territorial possível". Segundo o autor, deixou de ser necessário o emprego de "uma grande burocracia para gerar, organizar e transportar a informação através dos vários setores de uma firma qualquer" (DANTAS, 2003, p. 20).

Assim, como a maior parcela "dessa informação agora é organizada e transportada através de máquinas” (DANTAS, 2003, p. 20), tornou-se possível, nesse período, obter um benefício maior das "economias proporcionadas pelos sistemas de comunicação", fazendo com o que o trabalho vivo, anteriormente empregado, cedesse paulatinamente lugar ao trabalho morto (DANTAS, 2003, p. 20). 


\section{As dinâmicas recentes do circuito espacial de produção de ATMs e a expansão do sistema bancário brasileiro nos anos 2000}

Nesse capítulo busca-se compreender: quais foram as dinâmicas econômicas e territoriais após a abertura comercial dos anos 1990? Em que medida é possível explicar o fato de, apesar de haver empresas nacionais neste ramo de atividade, as grandes indústrias instaladas para a produção de equipamentos e de softwares para ATMs são majoritariamente estrangeiras (Diebold, NCR e OKI Brasil)? Como ocorre hoje a produção e a incorporação de novos ATMs diante de um quadro de profundas transformações na formação socioespacial brasileira, com os novos objetos informacionais (difusão de smartphones, tablets etc.), as redes-suporte para uso da internet e do fluxo de dados (a partir de redes de fibra ótica e da cobertura do sistema $3 \mathrm{G}$ no território nacional), as políticas e marcos regulatórios estatais (com destaque para a consolidação do sistema de pagamentos brasileiro e dos correspondentes bancários como importante fixo de oferta de serviços bancários)?

\subsection{Os recentes desdobramentos do circuito espacial de produção de ATMs}

Com a instituição do Plano Real, além de ter sido completado o processo de redução das tarifas de importação de uma série de produtos, houve a sobrevalorização da moeda nacional, o que aumentou o fluxo de importação e institui a referida situação de fragilidade estrutural da economia brasileira.

Conforme a explicação de P. N. Batista Jr. (2005, p. 24-25), de 1994 a 1998, prevaleceu o esquema de bandas cambiais e a sobrevalorização do Real, "que produzia acentuado desequilíbrio externo e subordinava a política monetária à defesa da taxa de câmbio e da posição de balanço de pagamentos". Com o ataque especulativo, em janeiro de 1999, "o governo brasileiro foi finalmente obrigado a deixar o real flutuar"; segundo o autor, percebeu-se então que não era prudente "estabelecer parâmetros fixos num mundo em que predominam moedas flutuantes e a mobilidade internacional de capitais". 
Dessa maneira, com a passagem para o câmbio flutuante tornou-se possível (BATISTA JR, 2005, p. 25-26): a) uma maior margem de manobra para o governo e o Banco Central, favorecendo uma orientação "em alguma medida para objetivos internos, não precisando mais reagir de forma quase automática à evolução dos juros externos e às oscilações do ambiente internacional"; b) o governo, ainda que de forma não planejada e inesperada, deu-se conta que seria possível "passar para um regime cambial mais adequado e registrar uma depreciação de grandes proporções sem perder controle sobre a inflação", o que permitiu, ao Banco Central, "iniciar um período de redução gradativa das taxas de juros internas, estimulando a reativação dos níveis de demanda, produção e emprego"; e c) redução da compra de bens e serviços no exterior, induzindo "um movimento de substituição de importações por produção nacional em diversos setores da economia", reduzindo significativamente os déficits nas balanças comercial e de pagamentos ${ }^{31}$.

Houve, nesse sentido, conforme a análise de P. N. Batista Jr. (2005), uma resposta vigorosa das empresas, por meio do aproveitamento da depreciação das taxas de câmbio (primeiro em 1999, seguida de uma outra em 2002) e do cenário externo favorável (após 2002). Esse é um aspecto essencial na explicação da conversão dos déficits da balança de pagamentos - pela primeira vez desde o início do Plano Real - em superávits crescentes a partir de 2002: no ano de 2003, chegouse a um saldo da balança comercial próximo aos US\$ 25 bilhões e a um superávit em transações correntes na ordem dos US\$ 4 bilhões; em 2004, o superávit comercial subiu para valores próximos a US\$ 34 bilhões e a conta corrente US\$ 12 bilhões (BATISTA JR, 2005).

Isso porque houve um forte crescimento das exportações do Brasil, segundo P. N. Batista Jr. (2005, p. 60), "acima da média mundial, tanto em termos de valor como de quantum exportado", chegando a uma situação em que "pela primeira vez desde o lançamento do Plano Real em 1994, o Brasil registra, ao mesmo tempo, crescimento econômico significativo e superávits no balando de pagamentos em conta corrente (BATISTA JR, 2005, p. 63).

\footnotetext{
${ }^{31}$ Segundo P. N. Batista Jr (2005, p. 26), “o déficit da balança comercial diminuiu consideravelmente, passando de US\$ 6 bilhões em 1998 para US\$ 1,3 bilhão em 1999, e US\$ 0,8 bilhão em 2000. O déficit em conta corrente, que inclui, além da balança comercial, serviços, rendas e transferências unilaterais, caiu de US\$ 33,4 bilhões em 1998 para US\$ 25,3 bilhões em 1999 e US\$ 24,2bilhões em 2000”.
} 
Deve ser ressaltado que a partir de 2003 houve uma reorientação da política econômica do país. Segundo A. Palocci Filho (2003, p. 59), uma orientação da política econômica de 2003 em diante deveria ser a de buscar "caminhos inovadores", com: i) Políticas horizontais de fortalecimento institucional; ii) Mudanças no sistema de crédito; e iii) Melhoria da infraestrutura e da logística. Para ele, eram necessárias "inciativas setoriais transparentes, com contrapartidas bem definidas e limites no tempo", dentro das quais situavam-se

inciativas a adoção de políticas industriais orientadas para impulsionar as exportações, com estímulo à produção de bens de maior valor agregado, desenvolvimento de marcas e prestação de serviços. Tais políticas deverão, também, contribuir para uma cuidadosa substituição competitiva de importações (PALOCCI FILHO, 2003, p. 59).

Além destas medidas, argumentava-se, à época, não ser razoável que "alguns setores industriais tenham, sozinhos, déficits comerciais anuais de alguns bilhões de dólares", sem que se buscasse "explorar caminhos para a produção local, adensamento e inovação das cadeias produtivas" (PALOCCI FILHO, 2003, p. 59). De forma enfática, discutia-se também a experiência de ação do Estado acerca do processo de liberalização comercial e a necessidade de se ter uma estratégia de inserção do país na economia global:

já aprendemos o bastante nos anos de 1990 para evitar a falta de planejamento e de políticas setoriais, em nome de ideias genéricas sobre inserção do país na economia global, apenas com o recurso da abertura de mercado. O Brasil é complexo o suficiente para exigir estratégias diversificadas de desenvolvimento industrial (PALOCCI FILHO, 2003, p. 59).

Assim, defendia-se, a necessidade de articulação entre políticas regionais e setoriais, de modo a garantir que, a despeito das diferenças regionais, deveria ser buscada uma indução no crescimento econômico das regiões, de modo a evitar que esse processo ficasse atrelado a uma guerra fiscal.

Para tanto era preciso que as políticas setoriais e regionais se apoiassem "na produção, absorção e difusão de tecnologia", de modo que a "busca da inovação" se tornasse "uma constante nas empresas e nos institutos públicos, com ênfase na pesquisa aplicada" (PALOCCI FILHO, 2003, p. 59 e 60). Na visão de um dos mais importantes formuladores da política econômica daquele momento:

Desenvolver esse ambiente pró-inovação é fundamental para atrair investimento estrangeiro com forte conteúdo tecnológico; impulsionar a empresa nacional de base tecnológica e oferecer os estímulos corretos para a produção, difusão e 
absorção de tecnologia, tanto na indústria e nos serviços como na agricultura e na pecuária. É o que poderá diversificar nossa base exportadora e dar-lhe maior musculatura para competir no mundo" (PALOCCI FILHO, 2003, p. 60)

Essas considerações, acerca de como eram vistas as estratégias e orientações políticas, são fundamentais para se compreender não apenas os resultados macroeconômicos apresentados anteriormente, como também a política industrial estabelecida a partir de então - que norteou todas as outras que foram implementadas a partir de 2003.

Essa política, consubstanciada no documento "Diretrizes de Política Industrial, Tecnológica e de Comércio Exterior" (DPITCE) de 2003, estabelecia como objetivo o "aumento da eficiência da estrutura produtiva, aumento da capacidade de inovação das empresas brasileiras e expansão das exportações". Aí estaria o fundamento de "uma maior inserção do país no comércio internacional", com o estímulo de "setores onde o Brasil tem maior capacidade ou necessidade de desenvolver vantagens competitivas, abrindo caminhos para inserção nos setores mais dinâmicos dos fluxos de troca internacionais" (DPITCE, 2003).

O documento propunha uma articulação com outras políticas e ações do governo, como a promoção do desenvolvimento regional e dos investimentos em infraestruturas. No primeiro caso, via-se a necessidade de "uma maior integração nacional e para a redução das disparidades regionais entre estados e sub-regiões", relacionando a importância dos "seus elos de articulação com a integração físicoeconômica do território, através do esforço de setor público, em parceria com o setor privado, na melhoria da infraestrutura de transportes, energia e telecomunicações". Já no segundo caso, acreditava-se que "a melhoria da infraestrutura, em conjunto com uma política regional com vistas a facilitar uma maior integração territorial, irá fortalecer as competências, vocações e oportunidades tecnológicas regionais"; havia uma concepção estratégica dos investimentos em infraestrutura, que poderiam se transformar "numa oportunidade para planejar e articular as demandas para a indústria de bens de capital" (DPITCE, 2003).

Outro aspecto relevante da política industrial foi colocar a inovação como elemento-chave a ser perseguido, na busca por uma maior competitividade nacional e internacional. Consideraram-se, então, as políticas de governo "como um 
conjunto integrado", nas quais estariam interligados "simultaneamente o estímulo à eficiência produtiva, ao comércio exterior, à inovação e ao desenvolvimento tecnológico como vetores dinâmicos da atividade industrial" (DPITCE, 2003). Assim, deveriam ser buscados:

- Maior exportação de bens manufaturados com maior intensidade tecnológica ${ }^{32}$;

- Desenvolvimento de sistemas empresariais maiores e grandes empresas nacionais com capacidade de liderança ${ }^{33}$;

- Implementação de políticas de integração e das interações institucionais ${ }^{34}$;

- Aumento da capacidade e da escala produtiva ${ }^{35}$;

- Estruturação de um "Sistema Nacional de Inovação"36.

Dessa maneira, segundo R. R. de S. Lima (2012), essa política foi de fundamental importância para o complexo eletrônico no país, na medida em que estabeleceu diferentes focos de atuação. Em 2003, houve o enfoque no desenvolvimento das indústrias de circuitos integrados, posteriormente, com o aprofundamento proposto pela política de desenvolvimento produtivo foi colocada a prioridade na produção de circuitos integrados e displays, que está mantida até hoje. Além disso, essas Diretrizes estruturaram um novo aprofundamento da ação

32 "No comércio exterior brasileiro destaca-se, em especial, a baixa contribuição dos mais variados segmentos das tecnologias de informação e comunicação, assim como da química fina, a exemplo dos fármacos, para a pauta de exportações brasileira. Inversamente, esses setores são os que mais contribuem para a elevada concentração de déficits localizados na balança comercial" (DPITCE, 2003).

33 “Aumentar a inserção externa e a capacidade de inovação da indústria guarda forte relação com o desenvolvimento de sistemas empresariais maiores e mais compatíveis com as dimensões das corporações internacionais. Contar com grandes empresas nacionais que sejam ativas na liderança do crescimento brasileiro é fundamental para consolidar processos inovadores consistentes" (DPITCE, 2003).

34 "Em países como o nosso, o cruzamento de competências e atributos descritos acima exige o concurso do Estado e a implementação de políticas de integração e de estímulo a um salto de qualidade na indústria. Nenhuma tecnologia minimamente complexa é perfeitamente transferível como se fosse uma commodity. Para dar sustentabilidade a esse conhecimento, é preciso promover interações institucionais e empresariais e uma articulação fina com os sistemas educacionais e centros de pesquisa, de modo a que seja cultivado um novo ambiente industrial de cooperação" (DPITCE, 2003).

35 "Considerando a vulnerabilidade externa da economia brasileira - o que exigirá a manutenção de grande esforço exportador da indústria, em especial dos setores de bens intermediários - e a retomada do crescimento do mercado interno, é fundamental que haja investimentos nesses setores, de modo a conciliar o atendimento de ambos os mercados" (DPITCE, 2003).

${ }^{36}$ Segundo o documento, a estruturação desse sistema envolveria uma "articulação de agentes voltados ao processo de inovação do setor produtivo, em especial: empresas, centros de pesquisa públicos e privados, instituições de fomento e financiamento ao desenvolvimento tecnológico, instituições de apoio à metrologia, propriedade intelectual, gestão tecnológica e gestão do conhecimento, instituições de apoio à difusão tecnológica(DPITCE, 2003)". Esse ponto será desenvolvimento com mais detalhes no subcapítulo seguinte. 
do Estado, em sua atuação junto aos círculos de cooperação do circuito espacial de produção de ATMs - como será visto no subcapítulo seguinte.

Mesmo com a manutenção do desequilíbrio da balança comercial do complexo eletrônico, com um forte déficit acumulado - desde pelo menos 1996 -, entre 2001 e 2009 esse conjunto de indústrias "de componentes eletrônicos, equipamentos de telecomunicações, informática, eletrônica de consumo e automação industrial obteve crescimento de receita de cerca de $14 \%$ acima do PIB, atingindo cerca de US\$ 57 bilhões de faturamento e cerca de 140 mil empregados ante 11 mil em 2001" (LIMA, 2012, p. 67). Há, atualmente, diferentes especializações produtivas na formação socioespacial brasileira, com Manaus concentrando as indústrias de eletrônica de consumo e algumas empresas importantes de informática. Em 2008 haviam 300 empresas cadastradas em 21 Estados (LIMA, 2012).

A seguir serão apresentadas as dinâmicas do circuito espacial de produção de ATMs desde o fim dos anos 1990 e durante os anos 2000.

\section{O circuito espacial de produção de ATMs e a topologia das empresas}

Esses processos de mudanças da conjuntura política e macroeconômica do país influíram nas dinâmicas do circuito espacial de produção de ATMs. Como reflexo da perda de dinamismo da indústria nacional e das políticas de aumento de importação, entre 1997 e 1999 o Brasil foi altamente deficitário nos fluxos de comércio exterior de Terminais de Autoatendimento Bancário, embora, tenha havido uma intensa demanda bancária por esses objetos técnicos - como será visto no subcapítulo posterior.

Como pode ser visto no Gráfico 1, essa demanda foi responsável por gerar correntes de transações nas cifras de US\$2.004.395 em 1997, US\$ 7.634.218 em 1998 e US\$ 12.688 .446 em 1999, totalizando um déficit acumulado de US\$ 21.191.729. 


\section{Gráfico 1 - Balança Comercial Brasileira: Fluxos de importação e exportação de Terminais de Autoatendimento Bancário, de 1997 a 2002 (em US\$)}

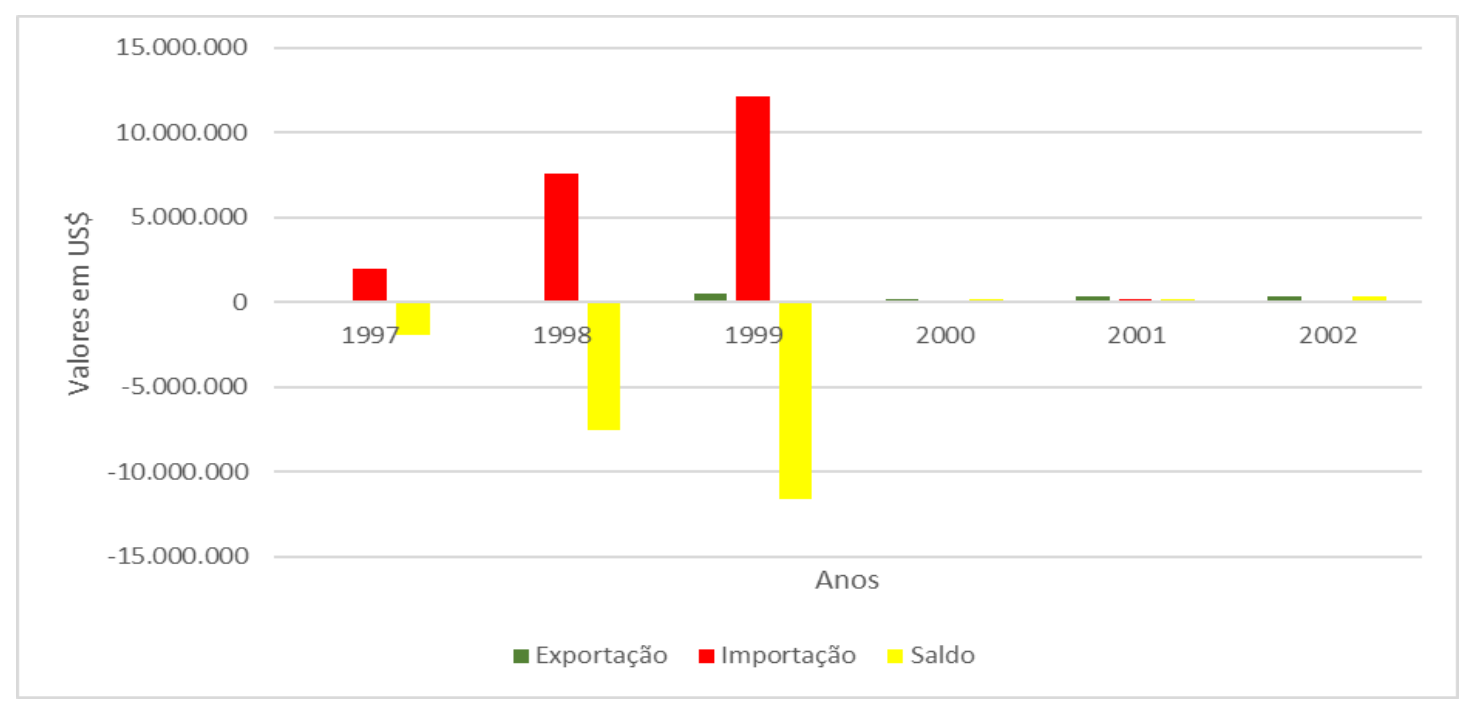

Fonte: Elaboração Própria, com base em dados disponibilizados por meio do sistema ALICEWEB - Ministério da Indústria, Comércio Exterior e Serviços/Secretaria de Comércio Exterior.

Somente a partir de 1999, com a crise cambial e a desvalorização do Real, as empresas puderam realizar um movimento de substituição de importações. Como resultado, a balança comercial comportou-se da seguinte maneira: as correntes de US\$ 277.899 em 2000, US\$ 492.329 em 2001 e US\$ 416.615 em 2002, muito embora tenham sofrido queda em relação ao triênio anterior, registraram um superávit acumulado no valor de US\$ 1.395.296. No entanto, em função do elevado déficit do primeiro triênio e da desestabilização das empresas nacionais, o período entre 1997 a 2002 registrou um saldo acumulado negativo de US\$ 20.540.308, com o segundo triênio (2000-2002) podendo ser caracterizado por uma reversão da tendência de queda e início de uma recuperação da balança comercial.

Do ponto de vista dos países envolvidos nesses fluxos, houve uma forte predominância do Reino Unido entre os países que exportaram para o Brasil, totalizando $95,12 \%$ do total de 12.232 ATMs importados pelo país (Mapa 1), o que significou uma transferência de recursos na ordem de US\$20.376.147. Em função do aumento desse tipo de fixo bancário no território nacional, os estados de São Paulo e Espírito Santo foram os que mais receberam esses objetos técnicos, como pode ser visto na Tabela 1. 
Tabela 1 - Brasil: Estados Importadores de Terminais de Autoatendimento, 1997 a 2002 (em unidades)

\begin{tabular}{|l|r|r|r|r|r|r|}
\hline \multicolumn{1}{|c|}{ Estados } & \multicolumn{1}{|c|}{1997} & \multicolumn{1}{|c|}{1998} & $\mathbf{1 9 9 9}$ & $\mathbf{2 0 0 0}$ & $\mathbf{2 0 0 1}$ & $\mathbf{2 0 0 2}$ \\
\hline Amazonas & 0 & 2 & 0 & 0 & 0 & 0 \\
\hline Amapá & 5 & 2 & 26 & 0 & 0 & 0 \\
\hline Bahia & 0 & 0 & 1 & 0 & 0 & 0 \\
\hline Espírito Santo & 224 & 753 & 699 & 100 & 7 & 0 \\
\hline Rio de Janeiro & 62 & 1 & 0 & 0 & 0 & 0 \\
\hline São Paulo & 8.724 & 338 & 989 & 12 & 45 & 6 \\
\hline Paraná & 0 & 235 & 0 & 0 & 0 & 0 \\
\hline Rio Grande do Sul & 1 & 0 & 0 & 0 & 0 & 0 \\
\hline
\end{tabular}

Fonte: Elaboração Própria, com base em dados disponibilizados por meio do sistema ALICEWEB - Ministério da Indústria, Comércio Exterior e Serviços/Secretaria de Comércio Exterior.

Já no que diz respeito aos mercados das indústrias instaladas no Brasil, predominaram o Uruguai (63,19\%) e os Estados Unidos (19,79\%), perfazendo, juntos, $82,98 \%$ do total de 288 terminais exportados (Mapa 2). 
Mapa 1 - Importações de ATMs (1997-2002)

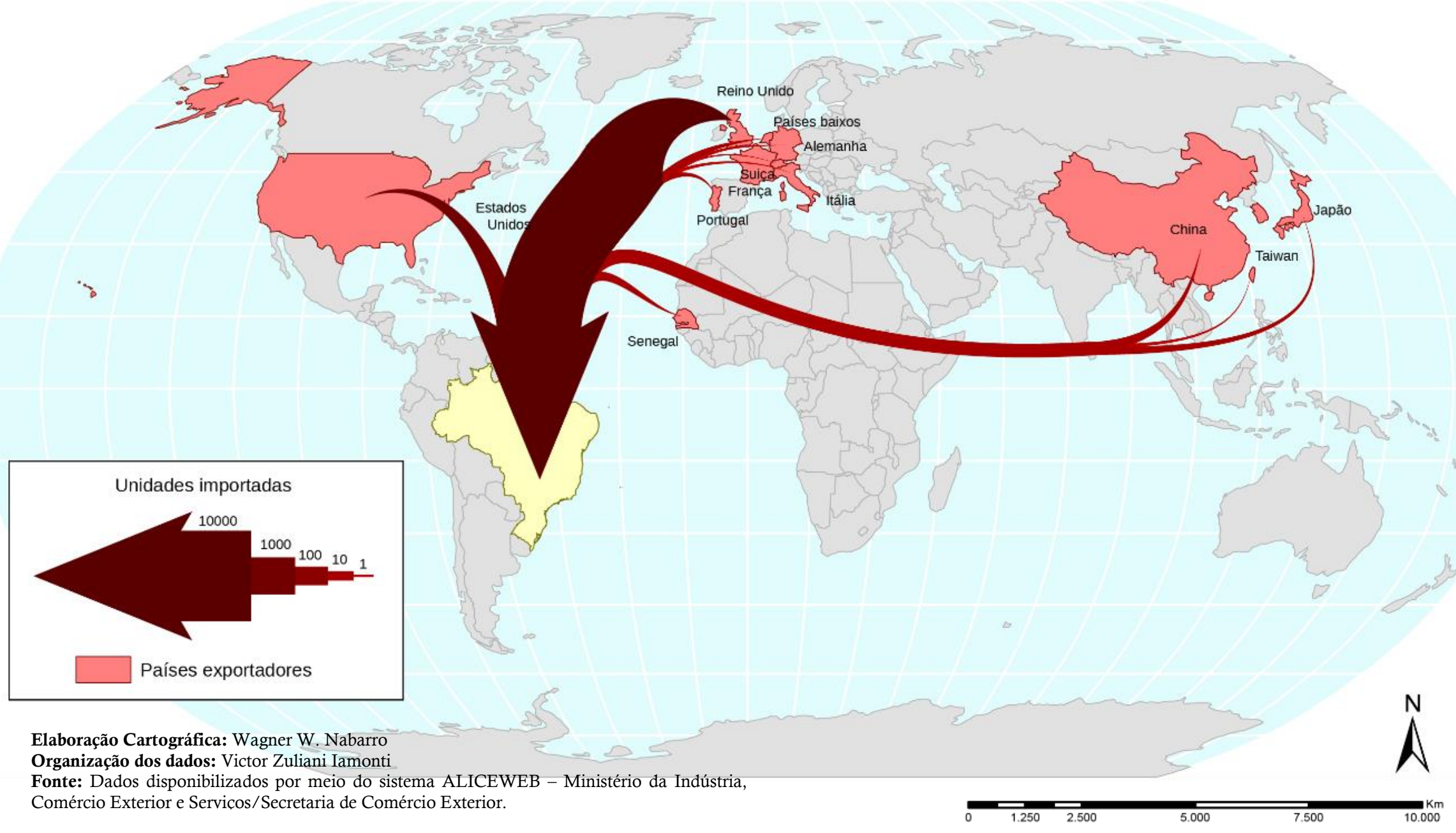


Mapa 2 - Exportações de ATMs (1997-2002)

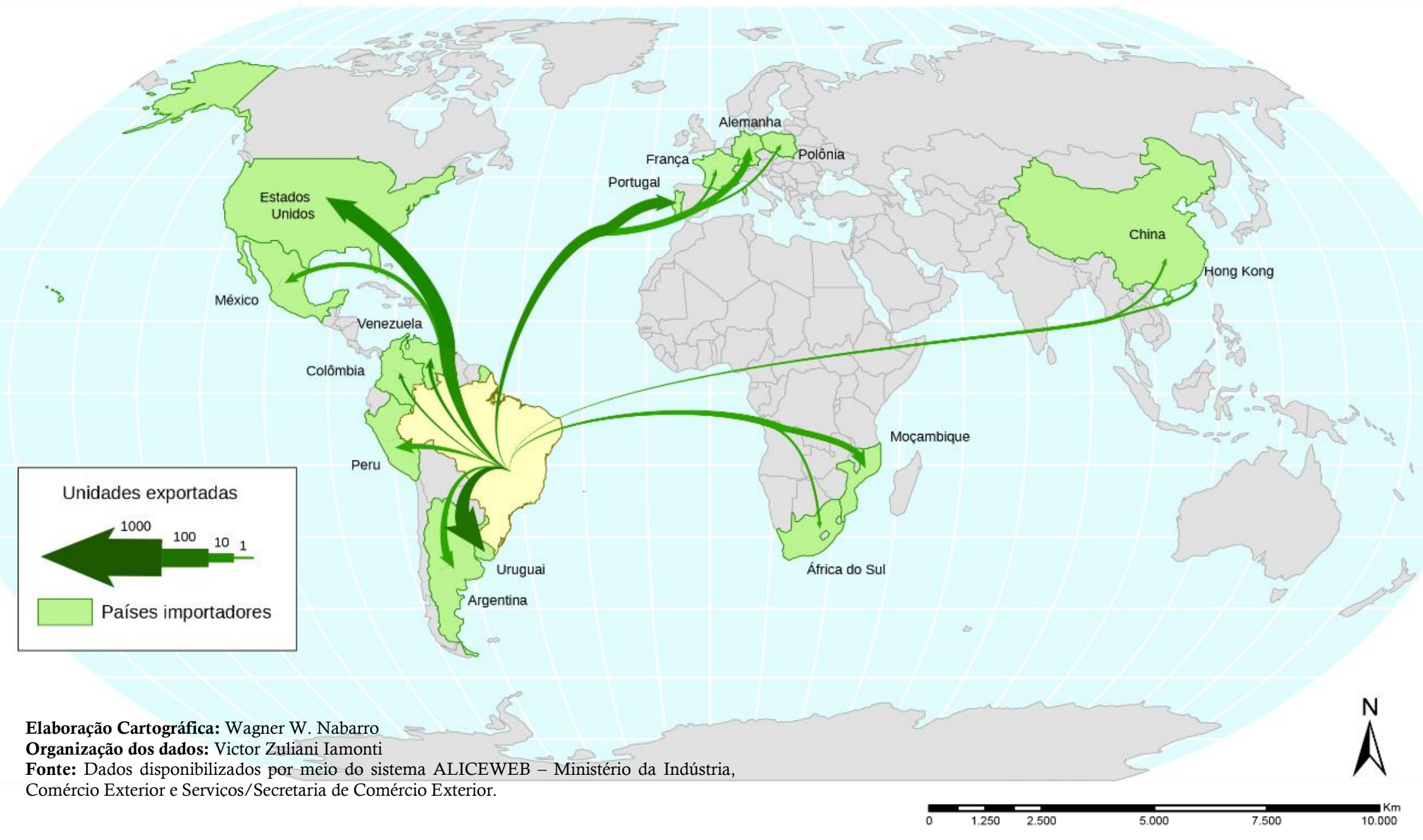


O total das exportações representou a vinda de US\$ 1.486 .797 para o país, sobretudo para o estado de São Paulo, que exportou 251 equipamentos $(87,15 \%)$ e recebeu US\$1.326.057 (89,18\%), como pode ser visto no Gráfico 2.

\section{Gráfico 2 - Brasil: Participação dos Estados na Exportação de ATMs, 1997 a 2002 (em}

\%)

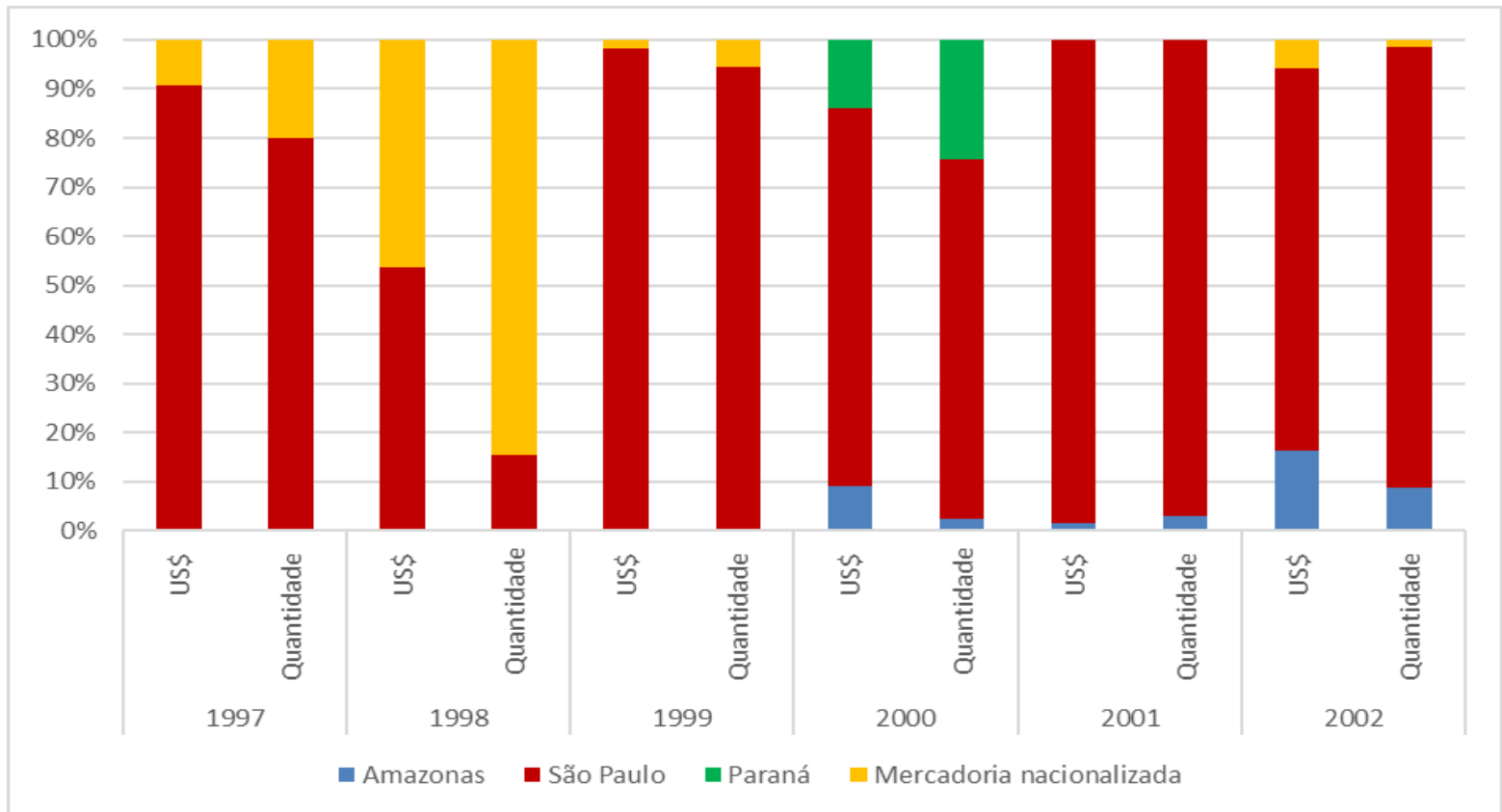

Fonte: Elaboração Própria, com base em dados disponibilizados por meio do sistema ALICEWEB - Ministério da Indústria, Comércio Exterior e Serviços/Secretaria de Comércio Exterior.

É interessante notar que a partir de 2003 as tendências do triênio anterior não apenas se mantiveram, como se consolidaram e se ampliaram, o que representou um forte superávit da balança comercial brasileira entre 2003 e 2008, sobretudo a partir de 2005, como pode ser visto no Gráfico 3. 
Gráfico 3 - Balança Comercial Brasileira: Fluxos de importação e exportação de Terminais de Autoatendimento Bancário, de 2003 a 2008 (em US\$)

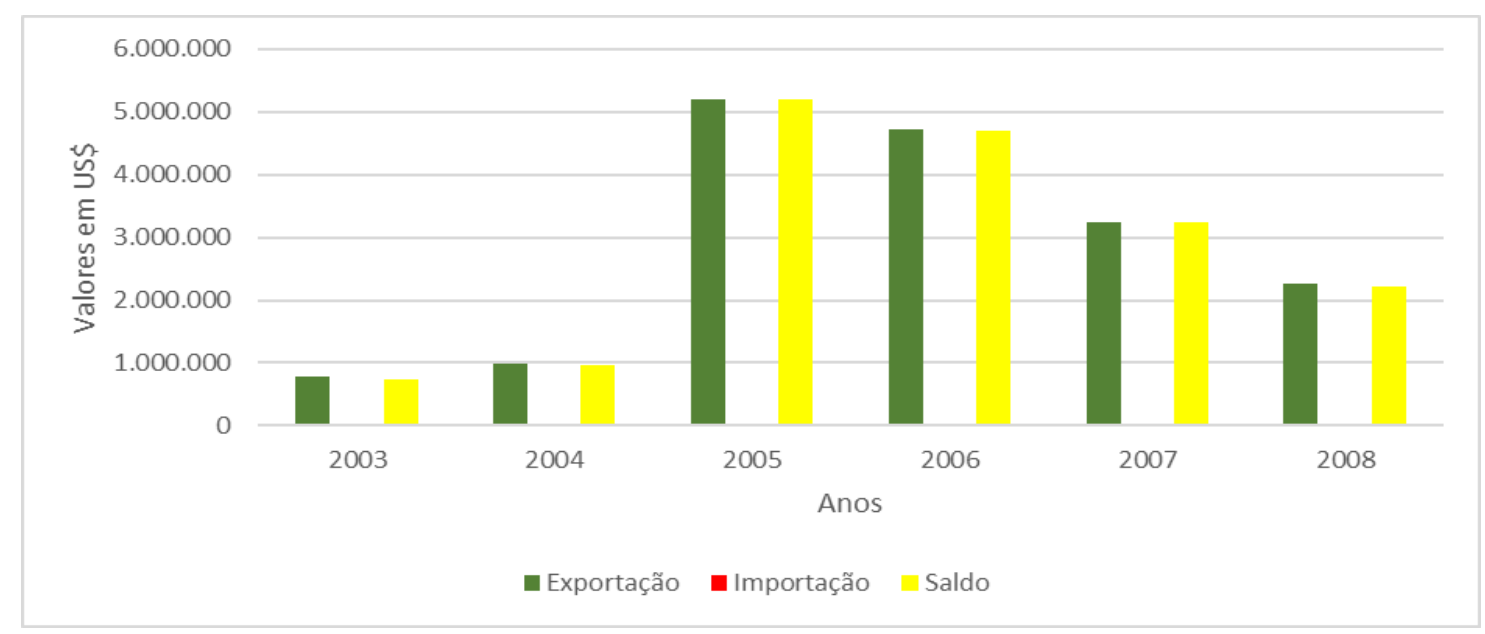

Fonte: Elaboração Própria, com base em dados disponibilizados por meio do sistema ALICEWEB - Ministério da Indústria, Comércio Exterior e Serviços/Secretaria de Comércio Exterior.

Os redirecionamentos políticos, com a mudança cambial e os esforços governamentais para uma política industrial e tecnológica, coordenada a uma política externa voltada para a abertura de novos mercados e uma maior presença do país na América Latina são elementos importantes, embora não sejam únicos, que contribuem para o entendimento dos dados da tabela anterior e dos mapas de fluxo de importação e exportação (Mapa 3 Mapa 3 - Importações de ATMs (20032008)e Mapa 4)..

Entre 2003 e 2005, houve um aumento de $684 \%$ em relação ao total de ATMs exportados no triênio 2000-2002, passando de um total de 288 unidades (2000-2002) para um total de 1.972 unidades. No triênio seguinte (2006-2008), o resultado foi ainda mais significativo, com o total passando para 4.371 unidades um aumento de $221 \%$ em relação ao período de 2003-2005.

Assim, as 6.343 unidades exportadas geraram um fluxo de US\$17.207.165 em direção ao Brasil. Do total desses equipamentos exportados, 95,25\% se direcionaram aos países da América Latina, com predominância do México (47,13\%), Colômbia (14,40\%), Chile (8,78\%), Uruguai (7,50\%), Equador $(5,31 \%)$ e Honduras (4,93\%). 
Mapa 3 - Importações de ATMs (2003-2008)

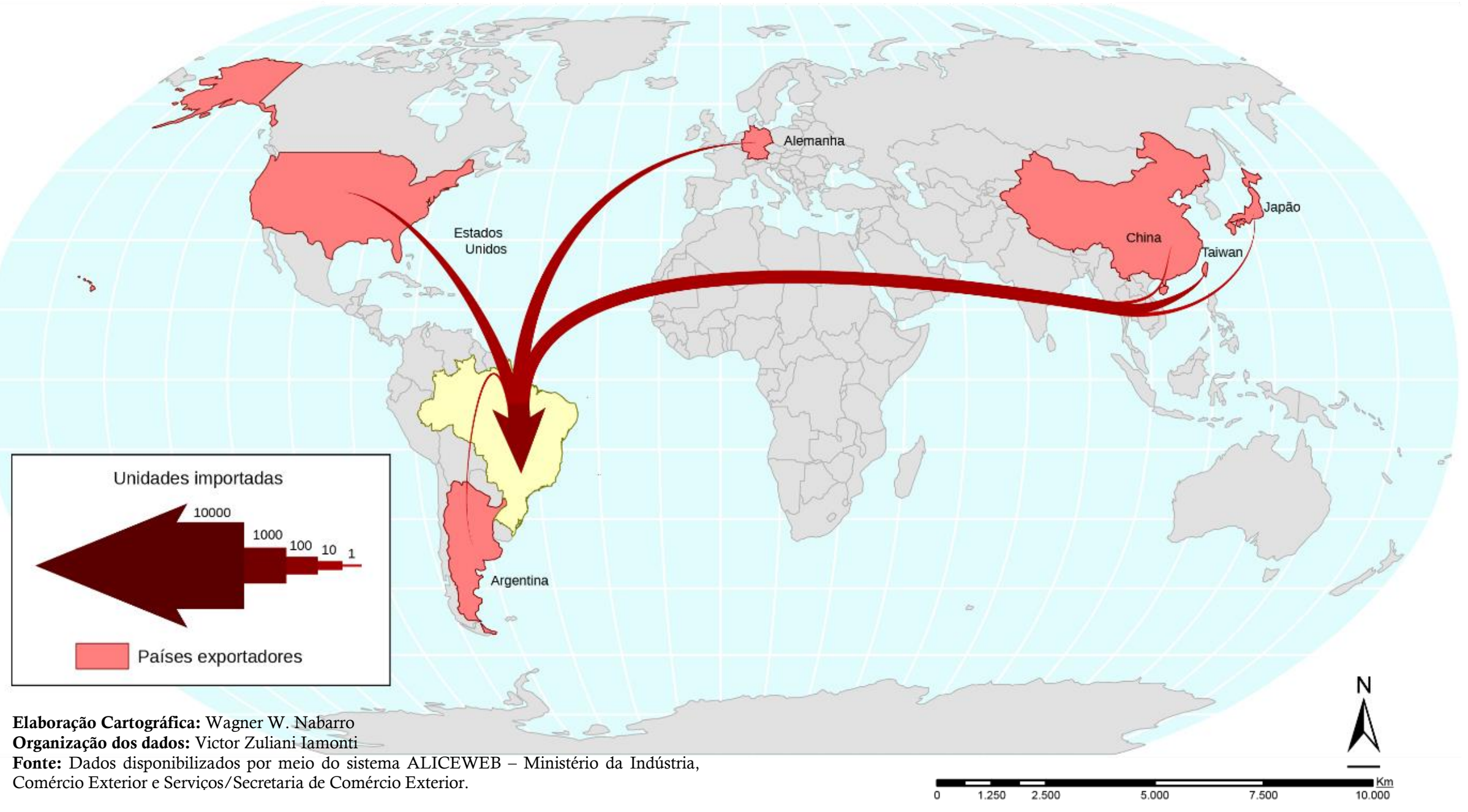


Mapa 4 - Exportações de ATMs (2003-2008)

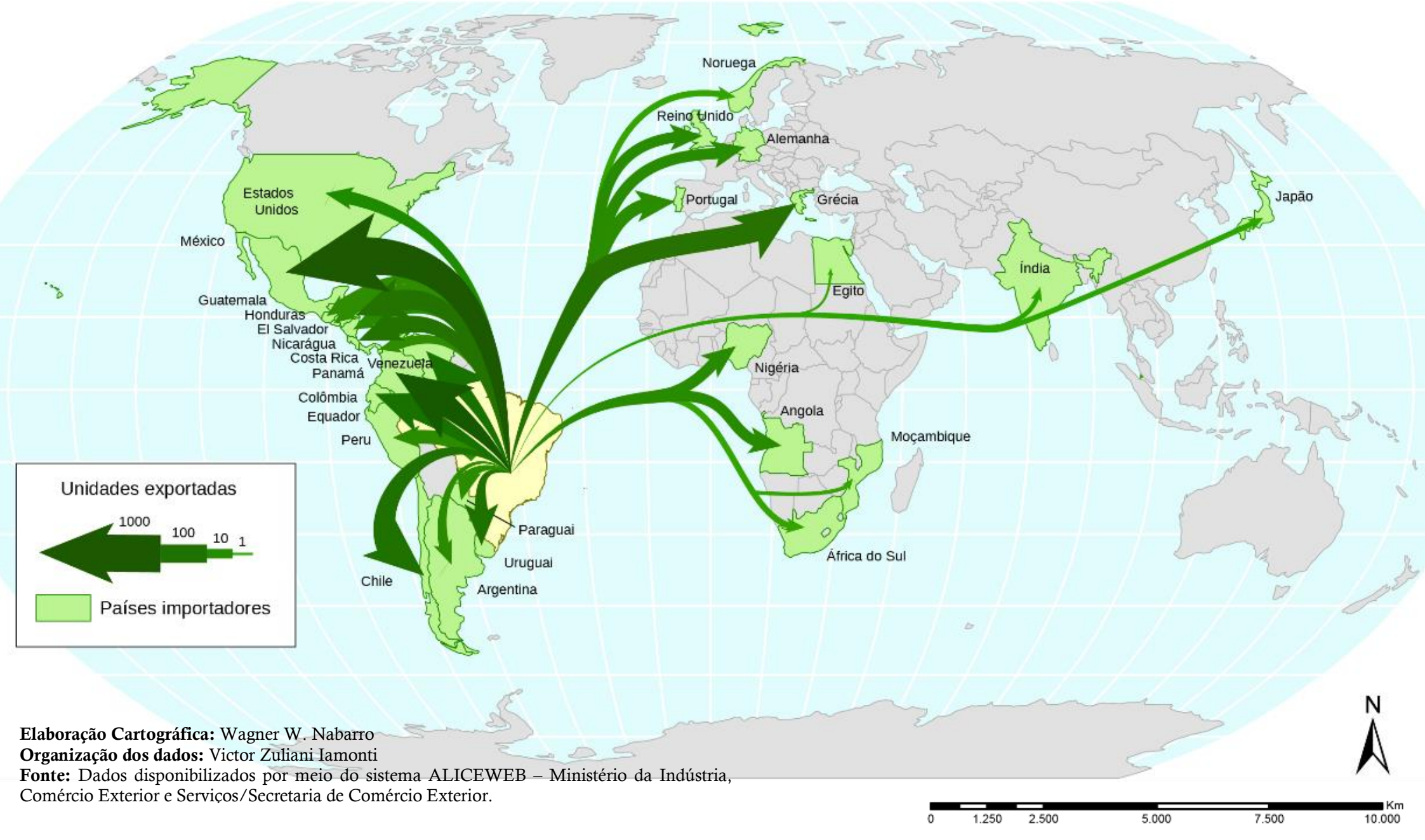


Ao se observar os estados exportadores (Gráfico 4), percebe-se que esse processo se deu de forma diferenciada dentro do território nacional, com uma menor preponderância de São Paulo em 2003 e nos anos de 2007 e 2008 (onde ficavam as fábricas da Itautec e da NCR). Destacavam-se a presença do Amazonas a partir de 2005 (onde estava instalada a fábrica da Diebold-Procomp) e do Rio Grande do Sul (onde se situava a fábrica da empresa Perto).

\section{Gráfico 4 - Brasil: Participação dos Estados na Exportação de ATMs, de 2003 a 2008 (em \%)}

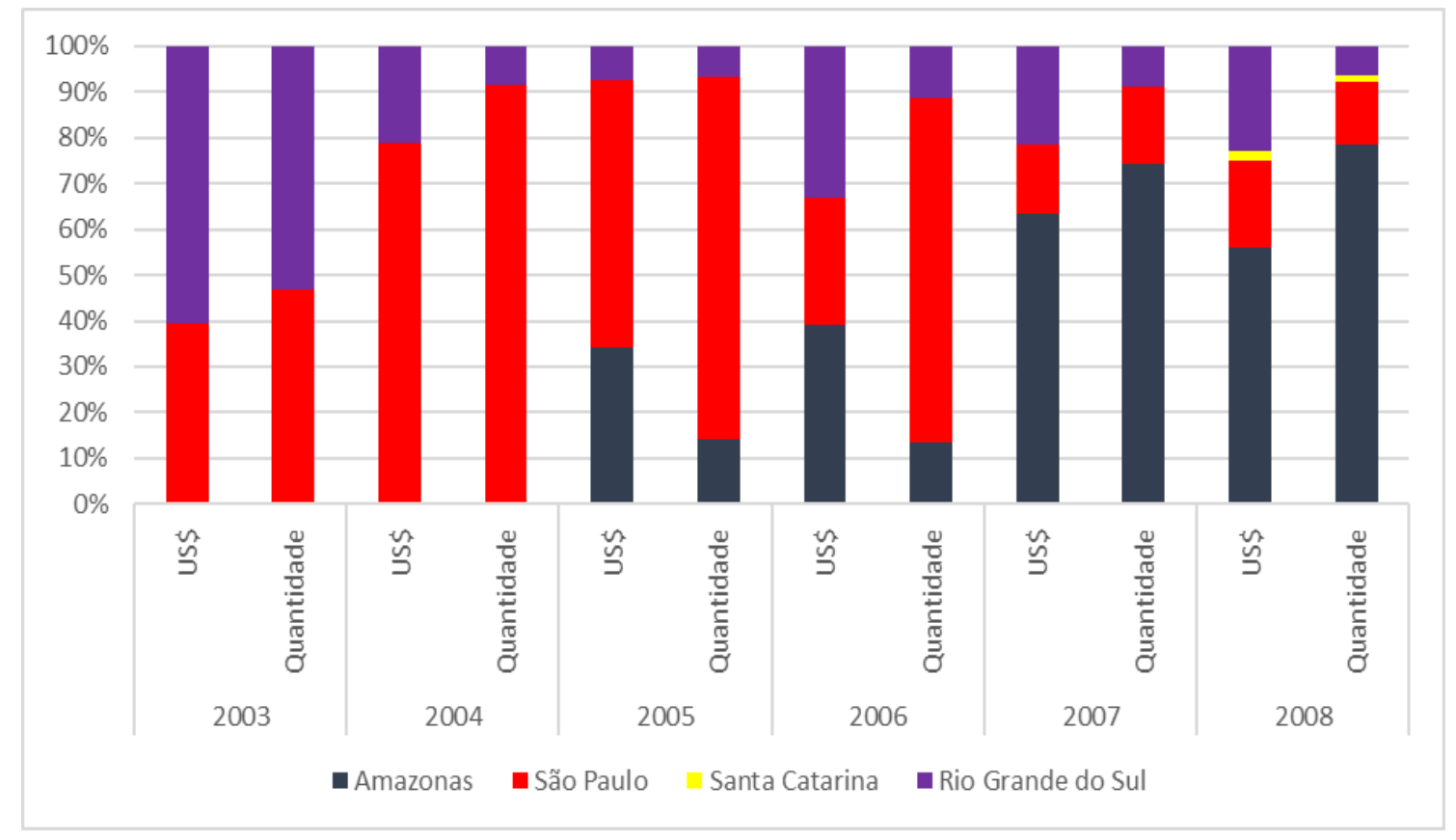

Fonte: Elaboração Própria, com base em dados disponibilizados por meio do sistema ALICEWEB - Ministério da Indústria, Comércio Exterior e Serviços/Secretaria de Comércio Exterior.

As importações nos dois triênios 2003-2005 e 2006-2008 sofreram uma ligeira queda em relação ao triênio 2000-2002 (que havia sido de 170 unidades), correspondendo a 61 (2003-2005) e 132 (2006-2008) unidades. No entanto, é preciso ressaltar que o total exportado foi 32 vezes maior que o total importado entre 2003-2005 e 33 vezes maior entre 2006-2008, enquanto que entre 2000 e 2002 o total exportado foi apenas 1,05 vezes maior que o total importado ao triênio anterior (1997-1999). Neste contexto, do total de 193 equipamentos importados entre 2003 e 2008, 96,37\% foram oriundos de três países: Alemanha (47,15\%), Estados Unidos (31,60\%) e Taiwan (17,61\%). 
No território brasileiro, como pode ser visto na Tabela 2, embora seja possível perceber a referida tendência de diminuição do total de importados, dentre os Estados receptores desses objetos técnicos São Paulo ainda se mantinha na liderança, seguido pelo Rio Grande do Sul e Amazonas e por Estados com presença pontual, como Paraíba, Distrito Federal e Rio de Janeiro.

Tabela 2 - Brasil: Estados Importadores de Terminais de Autoatendimento, 2003 a 2008 (em unidades)

\begin{tabular}{|l|r|r|r|r|r|r|}
\hline & 2003 & 2004 & 2005 & 2006 & 2007 & \multicolumn{2}{c|}{2008} \\
\hline Amazonas & 0 & 0 & 1 & 0 & 0 & 20 \\
\hline Paraíba & 0 & 0 & 0 & 4 & 0 & 0 \\
\hline Rio de Janeiro & 0 & 0 & 0 & 0 & 1 & 0 \\
\hline São Paulo & 8 & 25 & 27 & 24 & 2 & 3 \\
\hline Rio Grande do Sul & 0 & 0 & 0 & 74 & 0 & 0 \\
\hline Distrito Federal & 0 & 0 & 0 & 0 & 0 & 4 \\
\hline
\end{tabular}

Fonte: Elaboração Própria, com base em dados disponibilizados por meio do sistema ALICEWEB - Ministério da Indústria, Comércio Exterior e Serviços/Secretaria de Comércio Exterior.

Entre os anos de 2009 e 2014 houve, no geral, a manutenção da tendência superavitária atingida anteriormente, com valores totais próximos ao do período anterior de 2009 a 2012, mas com quedas nos fluxos de comércio registradas em 2013 e 2014. Como pode ser visto no Gráfico 5, entre 2009 e 2011 houve um fluxo de importação na ordem de US\$ 17.529 (2009), US\$ 10.437 (2010), US\$ 30.265 (2011), enquanto os de exportação apresentaram valores de US\$ 2.388 .460 (2009), US\$ 2.634.725 (2010) e US\$2.153.214 (2011), o que gerou saldos superavitários de US\$2.370.931 (2009), US\$2.624.288 (2010), US\$ 2.122 .949 (2011). 
Gráfico 5 - Balança Comercial Brasileira: Fluxos de importação e exportação de Terminais de Autoatendimento Bancário, de 2008 a 2014 (em US\$)

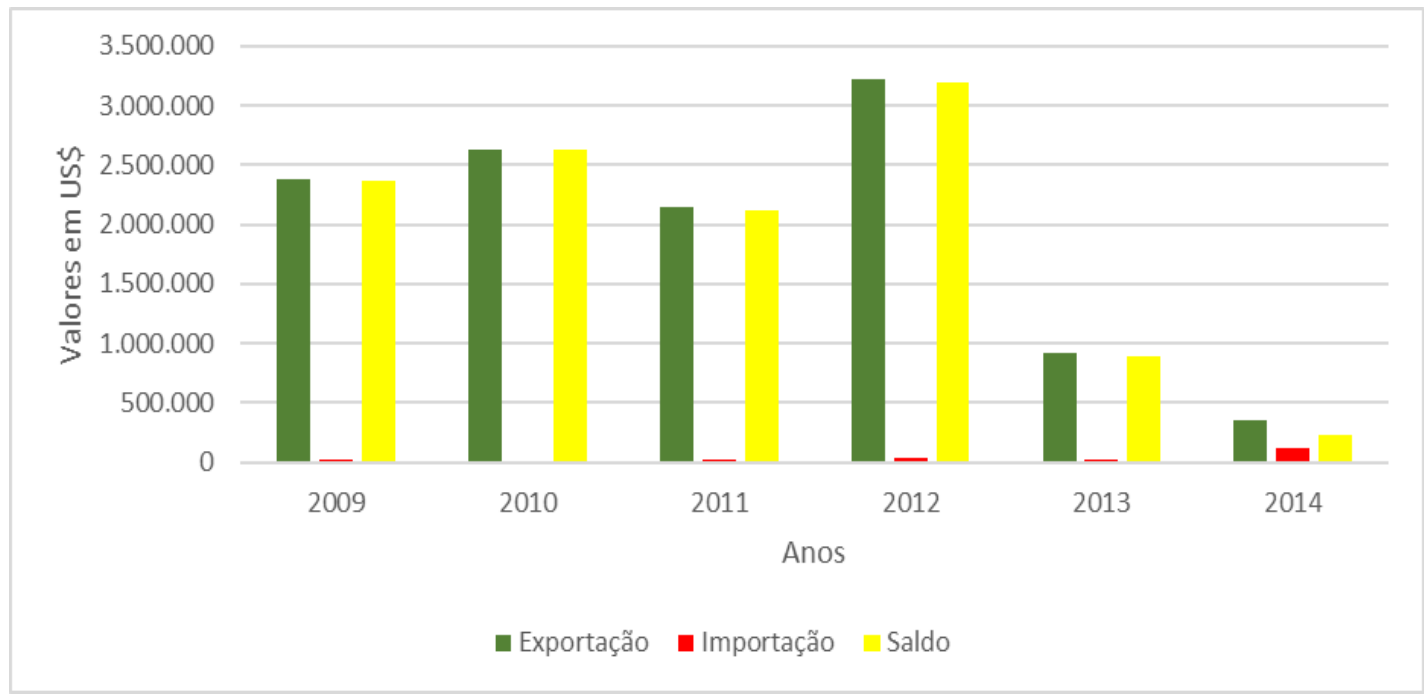

Fonte: Elaboração Própria, com base em dados disponibilizados por meio do sistema ALICEWEB - Ministério da Indústria, Comércio Exterior e Serviços/Secretaria de Comércio Exterior.

Entre 2012 e 2014, ainda que atingindo um pico de US\$ 3.228 .324 nos fluxos de exportação e de US\$ 34.543 nos fluxos de importação em 2012, iniciou-se uma tendência de queda: em 2013 registrou-se um valor de US\$ 920.515 para a exportação de ATMs (apenas $28 \%$ do total relativo ao ano anterior) e de US\$ 24.258 para a importação; em 2014, houve nova queda com resultados na ordem de US\$ 349.917 para os fluxos de exportação (38\% do total de 2013$)$ e de US\$ 122.265 no que tange à importação. Os saldos, mesmo continuando superavitários, comportaram-se da mesma forma, com um pico de US\$3.193.781 em 2012, e com uma queda para US\$ 896.257 no saldo de 2013 e uma nova redução, atingindo o patamar de US\$227.652 em 2014.

Houve um aumento do número de equipamentos importados, de 193 (20032008) para um total 372 unidades (2009-2014), sendo que a maior parte das 237 unidades (63,70\%) foi importada entre 2011 e 2014. Os principais países (Mapa 5) que destinaram ATMs para o Brasil foram: China (36,02\%), França $(27,15 \%)$ e Itália (17,47\%). Como pode ser visto na Tabela 3, os principais Estados receptores foram Paraná (45,16\% do total), São Paulo (24\%), e Minas Gerais (17,47\%). 
Tabela 3 - Brasil: Estados Importadores de Terminais de Autoatendimento, 2003 a 2008 (em unidades)

\begin{tabular}{|c|c|c|c|c|c|c|}
\hline & 2009 & 2010 & 2011 & 2012 & 2013 & 2014 \\
\hline Rondônia & 0 & 0 & 0 & 0 & 0 & 1 \\
\hline Amazonas & 0 & 0 & 0 & 0 & 8 & 8 \\
\hline Alagoas & 5 & 0 & 0 & 0 & 0 & 0 \\
\hline Minas Gerais & 0 & 0 & 0 & 0 & 0 & 65 \\
\hline Espírito Santo & 0 & 1 & 0 & 0 & 0 & 0 \\
\hline Rio de Janeiro & 1 & 0 & 1 & 19 & 0 & 0 \\
\hline São Paulo & 3 & 14 & 23 & 7 & 28 & 15 \\
\hline Paraná & 63 & 0 & 24 & 80 & 1 & 0 \\
\hline Rio Grande do Sul & 0 & 0 & 0 & 1 & 0 & 0 \\
\hline Distrito Federal & 0 & 0 & 0 & 0 & 0 & 4 \\
\hline
\end{tabular}

Fonte: Elaboração Própria, com base em dados disponibilizados por meio do sistema ALICEWEB

- Ministério da Indústria, Comércio Exterior e Serviços/Secretaria de Comércio Exterior. 
Mapa 5 - Importação de ATMs (2009-2014)

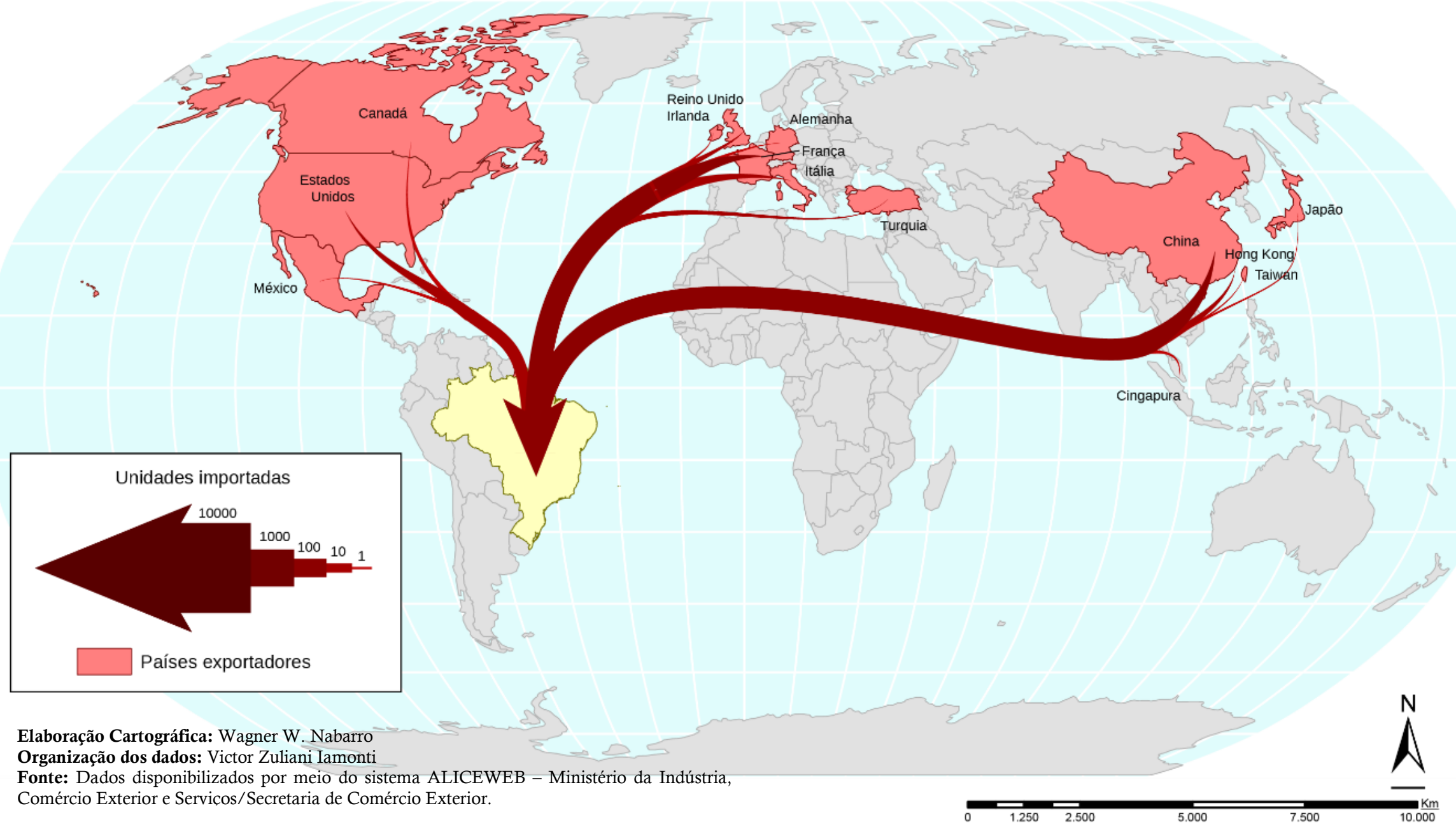


Os fluxos de exportação registraram um total acumulado de 6.431 unidades entre 2009-2014, com predominância de 70,46\% daqueles gerados no triênio 2012 2014. Apesar de ter sido registrado um leve aumento em relação aos totais de 20032008, é preciso ressaltar que esse período registrou uma aguda queda nos fluxos de saída desses equipamentos a partir de 2013: 91,21\% do total de 4.532 unidades exportadas no triênio 2012-2014 correspondem aos fluxos gerados em 2012.

Do ponto de vista dos países (Mapa 6) que receberam equipamentos, entre 2009 e 2014, continuaram predominando aqueles situados na América Latina (99,44\%), sobretudo o Haiti e o México, que receberam, respectivamente, $43,75 \%$ e $30,38 \%$ do total exportado. Esses fluxos partiram, principalmente, dos estados de São Paulo, Amazonas e Rio Grande do Sul, como pode ser visto no Gráfico 6Gráfico 6 - Brasil: Participação dos Estados na Exportação de ATMs, 1997 a 2002 (em \%).

\section{Gráfico 6 - Brasil: Participação dos Estados na Exportação de ATMs, 1997 a 2002 (em} \%)

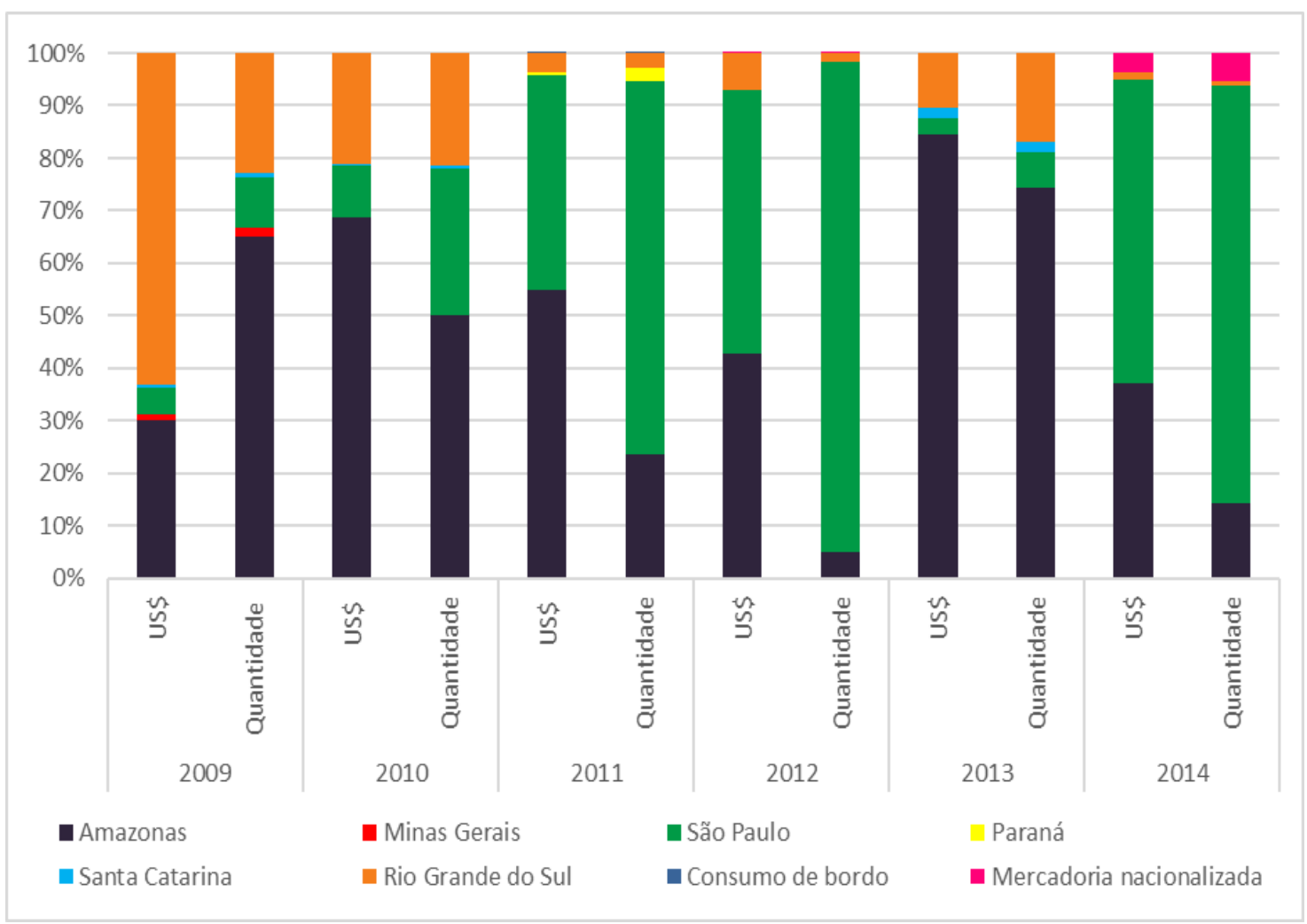

Fonte: Elaboração Própria, com base em dados disponibilizados por meio do sistema ALICEWEB - Ministério da Indústria, Comércio Exterior e Serviços/Secretaria de Comércio Exterior. 
Mapa 6 - Exportações de ATMs (2009-2014)

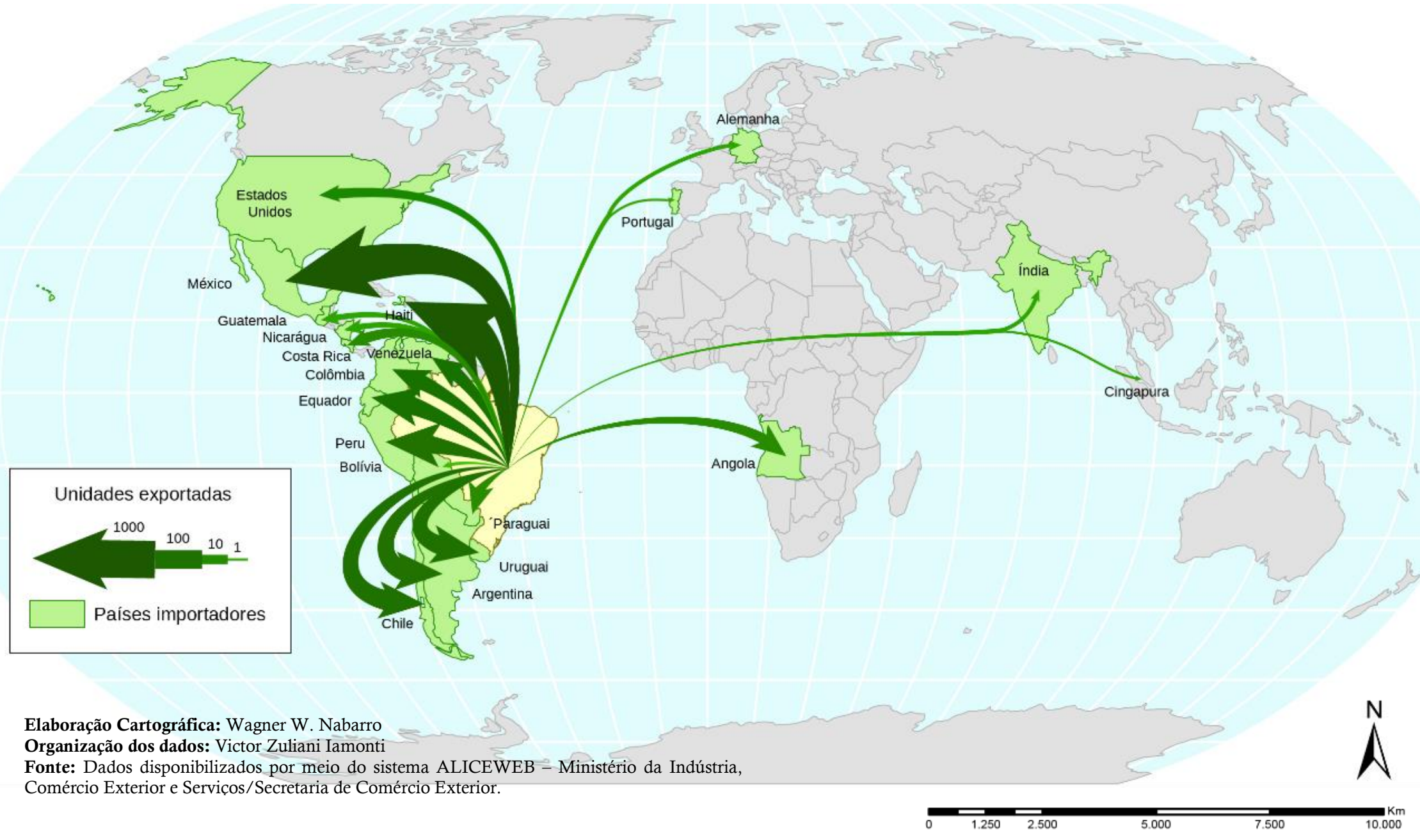


Pode-se sintetizar essas dinâmicas recentes, portanto, reconhecendo alguns pontos essenciais. O primeiro diz respeito à importância do entendimento do funcionamento do circuito espacial de produção, que, por estar fundado em um conjunto de trocas materiais e imateriais, garante uma unidade dinâmica da produção e do consumo, geralmente separados espacialmente, por meio de dois fluxos fundamentais: em um sentido, há o fluxo da mercadoria, no caso o ATM, enquanto que no sentido oposto, há o fluxo de dinheiro. Quando há a importação, o fluxo da mercadoria se define para dentro da formação socioespacial ou de uma região, enquanto o fluxo de dinheiro vai para fora. Na exportação há o oposto.

Já o segundo ponto a ser considerado, também fundado na ideia de unidade dinâmica entre produção e consumo, é o conjunto de relações estabelecidas: ao comunicar e solidarizar agentes dispersos pelos lugares, por meio dos fluxos, estudar o circuito permite o reconhecimento de: a) mercados, espacialmente e historicamente constituídos; b) especializações territoriais produtivas (ARROYO, 2001). Em ambos os casos, há, ao menos, duas escalas: os mapas de fluxos de importação mostram os países especializados na produção de ATMs, enquanto o Brasil é situado como um mercado dessas nações; já os mapas de fluxos exportação situam a formação socioespacial brasileira como um país especializado na produção desses terminais e os demais países consumidores de seus terminais. Pode-se falar, assim, em uma divisão do trabalho na escala planetária, que revela e indica países produtores e consumidores. Por outro lado, as tabelas e gráficos de importação e exportação por estado permitem-nos observar uma divisão do trabalho e uma especialização produtiva internamente à formação socioespacial brasileira, de caráter regional.

Ao considerá-las conjuntamente, podemos dizer, dessa forma, que se conformou nesses anos uma topografia do circuito interna e externamente à formação socioespacial brasileira. À escala planetária, a América Latina é, para o circuito espacial de produção existente no Brasil, o mais importante mercado; para América Latina o Brasil é um importante país especializado na produção desse objeto técnico. Os fluxos de exportação de ATMs são, nesse sentido, indicativos fundamentais que permitem observar as dinâmicas regionais e como essas estão inseridas no conjunto de trocas estabelecidas por esse circuito espacial de produção. 
Figura 6 - Esquema do Circuito Espacial de Produção de ATMs ${ }^{37}$

Complexo eletrônico

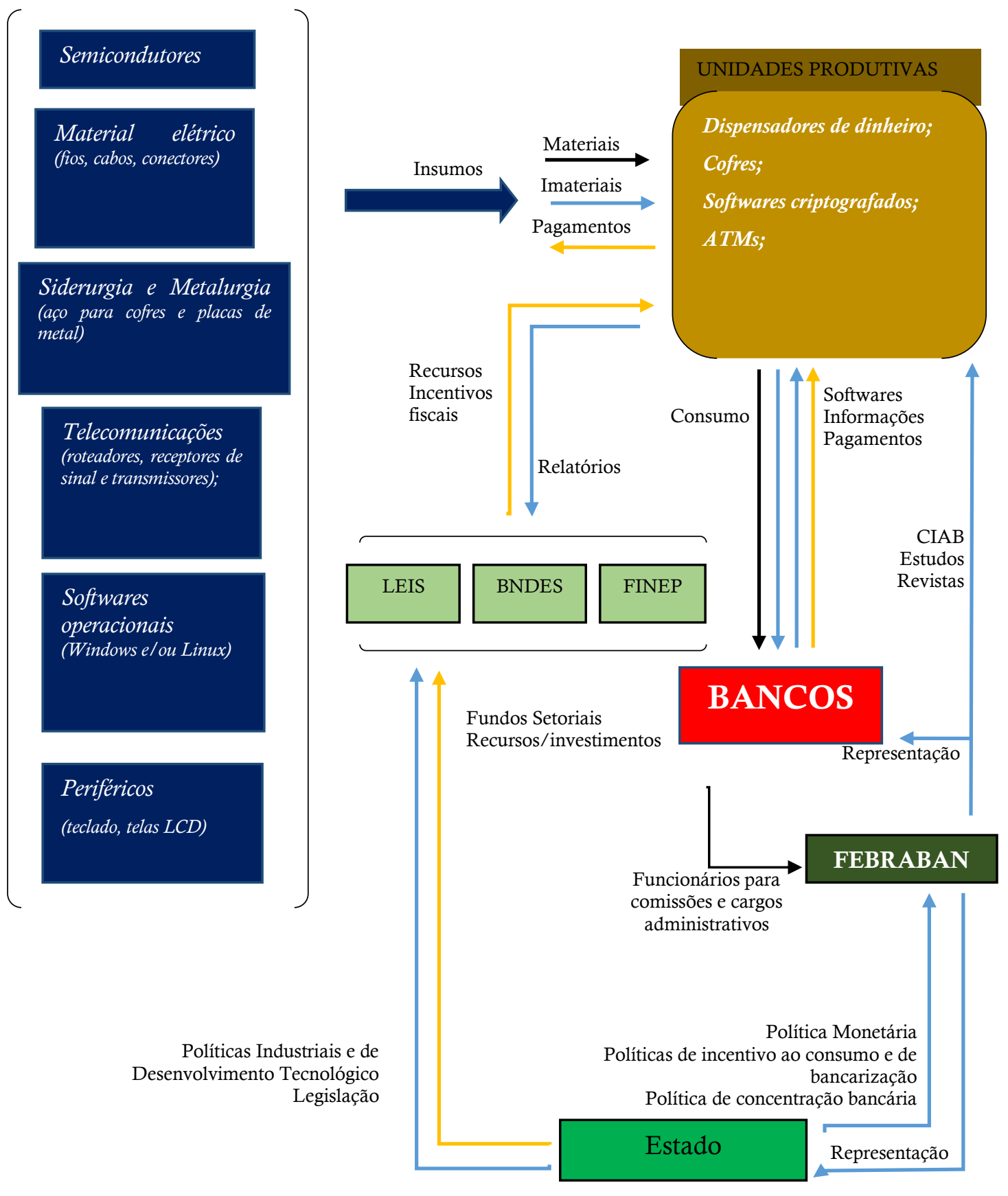

Círculos de cooperação

Fonte: Elaboração Própria.

${ }^{37}$ As relações estabelecidas nos círculos de cooperação serão discutidas no subcapítulo posterior. 
Os estados de São Paulo, Amazonas e Rio Grande do Sul, como visto, inserem-se ativamente nesse circuito, que é caracterizado por uma estreita relação com o chamado "complexo eletrônico" (Figura 6), cujas mercadorias - desde fios e cabos, até roteadores, periféricos, displays e softwares - são insumos para as empresas, que os utilizam para produzir os dispensadores de dinheiro e integrar eletronicamente o equipamento. Embora as indústrias siderúrgicas e metalúrgicas não façam parte do complexo eletrônico, também são consumidos o aço e placas de metal para fabricar cofres e a estrutura externa do equipamento.

Esses insumos são, então, utilizados pela indústria de ATMs, que produz, faz a montagem e a integração do sistema operacional comprado com o sistema criptografado a ser instalado no equipamento. Esse software é estratégico, pois garante a confiabilidade do ATM e cada empresa possui o seu, pois comandará, por sua vez, a execução das tarefas exigidas cotidianamente, como consultas, extratos, saques, estabelecendo a comunicação com o software do banco para atualização das posições de cada conta bancária.

Um aspecto importante para esse circuito é o fato do banco ser o ponto focal do circuito, assim como o hospital o é para o circuito da saúde (ANTAS JR, 2013). Segundo os entrevistados, tanto da empresa Diebold, quanto da OKI Brasil, os bancos brasileiros, por conta da liderança no processo de automação bancária e da sua participação nas empresas no período de vigência da reserva de mercado, adquiriram um know-how sobre os projetos ligados aos ATMs. Esse conhecimento historicamente acumulado pelos bancos faz com que o "ciclo da venda" seja longo: segundo o entrevistado da Diebold o processo de negociação para a venda de ATMs dura cerca de seis meses até que seja concluída. Esse é um fator importante que ajuda a explicar o fato de todas as empresas possuírem ou sede, ou escritório regional na cidade de São Paulo (ou em suas proximidades).

Ao mesmo tempo, deve-se ressaltar que, mesmo diante da recuperação da balança comercial da importação e exportação de ATMs, a partir de 1999 iniciou-se um processo de desnacionalização do controle das empresas do circuito espacial de produção. A escala do mercado brasileiro de automação bancária e as condições existentes nas diversas regiões do país para a produção de equipamentos foram importantes fatores para a aquisição de empresas nacionais. A primeira empresa a 
ser adquirida foi a Procomp, maior fabricante nacional de informática à época, pela empresa estadunidense Diebold. Em 1999, a empresa, considerada uma das maiores empresas nacionais de informática à época, foi comprada pelo valor de $\mathrm{R} \$$ 230 milhões. Em 2004 houve a instalação da empresa estadunidense NCR - líder do mercado global de fabricação e venda de ATMs -, em São Paulo. E, em 2013, houve a aquisição de 70\% das ações da Itautec pela empresa japonesa OKI Brasil.

Assim, o mercado nacional passou a ser caracterizado pela dominância de empresas estrangeiras (pelo menos $92 \%$ do mercado) e pela presença de poucos fabricantes nacionais. Em 2013, as participações das principais empresas eram da ordem de (BOUÇAS, 2014a e 2014b):

$\checkmark$ Diebold Procomp (EUA): 44\%;

$\checkmark$ OKI Brasil (Japão) - antiga Itautec: 30\%

$\checkmark$ NCR (EUA): $18 \%$

Como observou M. Arroyo (2001), dificilmente a topografia do circuito coincide com a topologia das empresas. Estas estabelecem uma infinidade de relações, que podem não necessariamente estar vinculadas apenas às áreas de produção e de consumo. De modo a apreender melhor a dinâmica das empresas será apresentada a topologia própria a cada uma.

\section{A topologia da Diebold (antiga Procomp)}

A primeira aquisição ocorreu com a compra da Procomp, maior fabricante nacional de informática à época, pela empresa estadunidense Diebold ${ }^{38}$. Em 1999, a empresa, considerada uma das maiores empresas nacionais de informática, foi comprada por R\$230 milhões.

O empresário paranaense Eric Roorda, um dos três sócios da empresa brasileira Procomp em 1999, tornou-se então o presidente do conselho de administração da subsidiária brasileira da empresa formada, e membro do conselho de administração da matriz da empresa, nos Estados Unidos.

\footnotetext{
${ }^{38}$ Esta empresa, cuja sede é a cidade de Cleveland, no Estado de Ohio (EUA), foi fundada em 1859. Desde sua fundação até grande parte do século XX foi especializada na fabricação de cofres. Na década de 1970 foi uma das precursoras da fabricação de Terminais de Autoatendimento no mundo. A partir de 1997 iniciou seu processo de internacionalização, cujas estratégias passaram a ser aquisições de empresas, abertura de escritórios e acordos de distribuição regionais.
} 
Desde os anos 2000 a subsidiária brasileira tem sido uma das principais "contribuintes" do faturamento global anual da companhia estadunidense. Como destacou E. Ferraz (2002), em 2001 as receitas arrecadadas no Brasil corresponderam ao montante de 290 milhões de dólares em 2001, o que significou $16 \%$ do total de receitas globais da Diebold.

Em 2000, destacava-se o contrato feito no valor de $\mathrm{R} \$ 115$ milhões para fornecimento de 196.000 urnas eletrônicas para o governo brasileiro (tido como o maior contrato de tecnologia do ano no país). Outro foco importante de atuação era a Caixa Econômica Federal - prestação de serviços necessários para o funcionamento dos 4.000 dos 18.000 ATMs desta instituição bancária. Com relação a esse contrato E. Ferraz (2002) ressaltou ainda que:

“A empresa não apenas realiza a manutenção dos equipamentos, ela também alimenta as máquinas com dinheiro, monitora em tempo real sua operação, contrata carros-fortes, instala dispositivos de segurança e cuida da manutenção dos quiosques. Até os caixas automáticos da CEF pertencem à Procomp [Diebold]. O banco paga um valor por transação realizada"

Em 2005, seis anos após a entrada da Diebold no mercado nacional, destacavam-se os seguintes aspectos da empresa (SALOMÃO, 2005):

$\checkmark$ Presença em 88 países;

$\checkmark$ Faturamento anual de US\$2,5 bilhões;

$\checkmark$ Controle de $60 \%$ do mercado brasileiro de automação bancária;

$\checkmark$ Principal fornecedora de Terminais de Autoatendimento para os bancos Bradesco e Caixa Econômica Federal.

Também em 2005, a empresa venceu o pregão da Caixa Econômica Federal e "fechou" contrato no valor de $\mathrm{R} \$ 213$ milhões de reais com esta instituição. O resultado foi o fornecimento de 25 mil terminais de apostas e pagamento de contas para equipar 9 mil lotéricas no Brasil. Esse contrato, cujas unidades foram produzidas na fábrica em Manaus, representaram um acréscimo de 12\% a 15\% no faturamento da empresa no ano de 2005 (FUOCO, 2005).

Segundo entrevista concedida em 2010, Tom Swidarsi, presidente de operações globais da Diebold, afirmou que o Brasil era o único país que a empresa produzia urnas eletrônicas. Além disso, o presidente afirmou que, em 2009, a Diebold produziu 18 mil ATMs no Brasil, total maior que o produzido pela 
empresa nos Estados Unidos e China juntos (17,5 mil unidades). A empresa também possuía contratos com a Caixa Econômica Federal para instalação de 610 servidores (computadores de grande porte) e 16,8 mil impressoras para o Banco do Brasil (BORGES, 2010).

Como evidenciou M. Ayres (2011), a subsidiária brasileira faturou 20\% do faturamento global da empresa estadunidense em 2011. Além disso, conforme reportagem da mesma revista, em 2011 a empresa era a responsável pela fabricação de 460.000 urnas eletrônicas até então em uso no Brasil (JULIBONI, 2011). Também fabricava os equipamentos abaixo (AYRES, 2011):

$\checkmark$ Terminais de pagamento para serem instalados em farmácias da América do Sul;

$\checkmark$ Terminais instalados em lotéricas;

$\checkmark$ Ganhou licitação de fabricação para o Ministério da Educação de 10.000 equipamentos que uniam computador e projetor.

Em 2012, comprou a empresa brasileira GAS Tecnologia, cujos softwares para proteção bancária, produzidos por 125 funcionários (incorporados à Diebold após a compra), renderam faturamento de aproximadamente $\mathrm{R} \$ 30$ milhões em 2011 (BARBOSA, 2012a).

Uma das estratégias recentes da empresa é a busca de setores interessados em ATMs, mas que não necessitem de entrega de dinheiro. Assim, a Diebold passou a oferecer estes equipamentos também para Pão de Açúcar, Riachuelo, Medial Saúde e hospital Albert Einstein (BORGES, 2010).

Segundo o sítio eletrônico da instituição, atualmente, a empresa é líder no mercado nacional de ATMs, com aproximadamente 100 mil unidades instaladas.

\section{A topologia da OKI Brasil (antiga Itautec)}

Desde que iniciou seu processo interno de reestruturação, em 1997, no início dos anos 2000 sua rentabilidade continuou oscilando. Em 2005, após ter contratado a consultoria McKinsey (cujos encargos foram de $\mathrm{R} \$ 500.000,00$ ), ampliou sua reestruturação, como relatou A. Salomão (2005): 
Vendeu a empresa Philco - seu "braço" no varejo e responsável então por $30 \%$ do faturamento - por $\mathrm{R} \$ 30$ milhões para a empresa Gradiente;

$\checkmark$ Reorganizou as suas indústrias - Duratex (madeira), Deca (louças e metais sanitários) e Eleikoroz (química);

$\checkmark$ Desmembrou sua unidade de fabricação de componentes e placas, dando origem à Companhia Brasileira de Componentes (CBC), que foi colocada à venda;

$\checkmark$ Redução de sua participação no mercado de computadores pessoais;

$\checkmark$ Fechou cinco unidades das lojas Trend Shop;

$\checkmark$ Como resultado, demitiu 1.000 funcionários, perdeu $15 \%$ do seu patrimônio e reduziu em $40 \%$ seu faturamento. Contudo, sua rentabilidade aumentou em 15\% (2005) e esperava-se atingir 20\% nos anos subsequentes.

Muito embora já houvesse um entendimento, por parte de especialistas da área, de que a tendência dos bancos seria de terceirização dos serviços, o presidente da empresa à época, Ricardo Setúbal afirmava que a Itautec não estava à venda, já que atendia o Itaú "com produtos sob medida, que outras empresas teriam dificuldade em oferecer" (SALOMÃO, 2005).

Assim, decidiu manter um dos seus focos na área de automação bancária, já que era uma área rentável da empresa. Havia também outros interesses - ligados à automação comercial -, como destacou A. Salomão (2005):

$\checkmark$ A expansão das exportações de ATMs para supermercados europeus, já que sua participação nas maiores redes, em Portugal, já era forte;

$\checkmark$ Venda desses equipamentos para Cassinos, nos Estados Unidos.

Em 2007, foi aprovado pelo BNDES um financiamento de R\$ 142 milhões destinados à pesquisa, ao desenvolvimento e à inovação em produtos e processos, ao aumento da capacidade produtiva e à expansão da atividade internacional com a aquisição da empresa estadunidense Tallard Technologies - distribuidora de produtos de informática, automação e serviços (BNDES, 2007). Essa última empresa foi comprada pelo valor de U\$ 16 milhões e passou a integrar as operações fora do Brasil da Itautec. Mantendo o nome original (Tallard Technologies), passou 
a estar presente na América do Norte e na América Latina, com escritórios locais em Miami (EUA) e em alguns países da região (Venezuela, México e Chile). Segundo matéria da revista Exame à época (2007),

Com 200 funcionários, a empresa será representante de equipamentos de marcas como IBM, Apple e Avaya - especializada na área de call centers. O presidente da empresa será Humberto Gonzalez. O faturamento do projeto é de 200 milhões de dólares.

Em 2010, a Itautec vendeu as ações representativas do capital social da Tallard Technologies por R\$ 69 milhões - segundo B. Olivon (2010) "45 milhões de reais referentes ao valor das ações alienadas e 24 milhões de reais relativos a créditos decorrentes de empréstimos".

A empresa continuou sendo uma "subsidiária integral" da Itautec e as principais "áreas de negócio" da empresa se mantiveram: automação, computação e serviços. Conforme apontou B. Olivon (2010):

A Tallard é uma distribuidora de valor agregado voltada para o fornecimento de soluções de TI. A empresa distribui servidores, software, periféricos, equipamentos de convergência e serviços de integração empresarial. Entre os clientes estão revendedores, provedores de soluções e integradores de sistemas.

Nesse mesmo ano, a Itautec investiu um total de R $\$ 70$ milhões em pesquisa e desenvolvimento e conseguiu criar duas inovações em ATMs:

$\checkmark$ Tecnologia 3D, para evitar que o cliente tenha contato direto com o cofre do equipamento;

$\checkmark$ Tecnologia de reconhecimento da face do cliente, que pode cancelar a operação caso apareça uma nova pessoa em frente a tela.

Ainda que possuísse uma forte presença no território nacional, em julho de 2013, 70\% das atividades de automação comercial e bancária da Itautec foram adquiridas pela empresa japonesa OKI. Segundo o jornal Valor Econômico (2013), com o acordo o grupo OKI possuirá "condições de entrar na disputa pela automação sob condições mais igualitárias frente às multinacionais já estabelecidas no Brasil, como Diebold e NCR".

No que diz respeito à participação no mercado de autoatendimento, a empresa japonesa, segundo o vice-presidente sênior Naoki Sato, já possuía 40\% de participação no Japão e 50\% na China. A OKI não desativou a fábrica da Itautec 
em Jundiaí (SP), que possui capacidade de produção de 2,5 mil ATMs por mês (Valor Econômico, 2013).

Uma questão importante, relativa à aquisição da Itautec, também diz respeito à expansão da oferta de produtos e serviços pelo território nacional, cuja capacidade de atendimento atingisse a marca de 3700 municípios, 33 filiais de serviços, 10 laboratórios de suporte e mais de 5.000 .000 de equipamentos em contratos de manutenção. Tal estrutura se completa com a participação de mais de 200 empresas nacionais credenciadas à Itautec, que prestam serviços de assistência técnica especializada.

\section{A topologia da NCR}

Até o ano de 2004, somado ao fato da empresa ocupar a liderança mundial na produção de ATMs, havia fornecido cerca de 8 mil terminais para o Brasil. Foi nesse ano que a empresa abriu sua quinta fábrica no mundo e primeira no país, localizada na cidade de São Paulo. A fábrica, projetada para fabricar cerca de 7 mil ATMs/ano, passou a atender o mercado nacional (FUOCO, 2004). No entanto, essa fábrica foi terceirizada posteriormente.

Em 2009, anunciou um plano de investimentos no Brasil até 2013 no montante de US\$ 73 milhões. Nesse mesmo ano, abriu fábrica para produção de ATMs em Manaus e um centro de pesquisas para desenvolvimento de inovações para o setor bancário em São Paulo. Além disso, em 2011 realizou outras duas iniciativas importantes:

$\checkmark$ Ampliou a fábrica, para também produzir cofres de aço para os caixas eletrônicos (DRSKA, 2011a). Essa unidade, em 2011, era a única da empresa no mundo que produzia esses cofres. Suas outras quatro fábricas - nos Estados Unidos, China, Índia e Hungria adquiriam tal equipamento de outros fornecedores.

$\checkmark$ Estabeleceu uma joint venture com a empresa Scopus (pertencente ao Banco Bradesco) para a produção de caixas eletrônicos em Manaus. A empresa estadunidense passou a controlar 51\% dessa fábrica e a brasileira 49\%. Segundo T. Moreira (2011), "o acesso à tecnologia da 
Scopus e a capilaridade da rede bancária do Bradesco [foram] os grandes atrativos do negócio para a companhia americana".

Em 2012, a NCR fez três aquisições no Brasil. Comprou as empresas POS Integrated Solutions, a Wyse Sistemas e a Radiant Distribution Solutions. O objetivo foi a busca pela liderança no mercado nacional de ATMs e de sistemas de vendas para lojas, canais online e dispositivos móveis (BARBOSA, 2012b).

Tais aquisições estavam articuladas em uma estratégia global da empresa. Nesse mesmo ano, adquiriu a empresa israelense de software chamada Retailix, cujo foco era o varejo. Tal fato, segundo M. Drska (2012b),

reforça a estratégia da NCR para diversificar seus negócios. Com forte atuação entre instituições financeiras, por meio da oferta de sistemas e caixas de autoatendimento (ATM), a companhia tem investido para ganhar participação no segmento de varejo

Em 2010 a receita líquida global da empresa foi de US\$ 4,8 bilhões de dólares - enquanto que em 2008 foi de US\$ 5,32 bilhões. E, em 2011, possuía 450 funcionários no Brasil (MOREIRA, 2011). Em 2015, a empresa era considerada líder global de produção de ATMs para instituições financeiras (com 29,5\% da base instalada mundial) e vem crescendo continuamente sua participação no mercado nacional.

\section{A topologia da Perto}

A empresa brasileira, localizada em Gravataí (RS), produz caixas eletrônicos desde os anos 1990. Em 2013 ampliou sua fábrica, investindo R\$ 38 milhões. Suas expectativas eram:

$\checkmark$ Dobrar a produção de máquinas Point of Sales (de 10.000 para 25.000 por mês);

$\checkmark$ Dobrar a produção de ATMs (para 1.500 unidades).

Nesse mesmo ano, começou a construir uma fábrica na Índia, na cidade de Jaipur (situada a $250 \mathrm{~km}$ de Nova Déli). Essa fábrica possuirá capacidade de produzir entre 600 e 800 caixas eletrônicos por mês; o investimento estimado é de US\$ 60 milhões (BUENO, 2013). 
Em 2015, adquiriu a área de caixas eletrônicos no Brasil da empresa alemã Wincor Nixdorf. Essa empresa transferiu sua produção para a fábrica da empresa, em Gravataí (RS). Segundo G. Brigatto (2015),

Pelo acordo, além da fabricação de máquinas com a marca Wincor, a companhia brasileira também vai usar peças da fabricante alemã em seus produtos especialmente as máquinas chamadas de recicladoras, que automaticamente transferem as notas depositadas pelos correntistas para a gaveta destinada a suprir as operações de saque.

\section{A topologia da Scopus}

A empresa foi criada em 1975 e, em 1989, adquirida pelo Bradesco. A Scopus foi responsável por atividades de suporte técnico, manutenção de equipamentos, sistemas e desenvolvimento tecnológico do banco. Segundo M. Drska (2013), em 2013 a empresa investia cerca de $\mathrm{R} \$ 4$ milhões de reais em inovação e o mesmo montante na capacitação dos funcionários. Em 2014, parte da empresa, desmembrada internamente em Scopus Serviços e Scopus Soluções, foi adquirida pela IBM.

A Scopus Serviços, cujas atividades concentram-se em suporte técnico, manutenção de equipamentos e sistemas passou a fazer parte da IBM no ano de 2014. Estas áreas foram responsáveis por cerca de dois terços do faturamento total da Scopus em 2013. Como resultados, foram transferidos 2,4 mil funcionários para a multinacional estadunidense, junto da responsabilidade de gerir um total de 30 mil ATMs pertencentes ao Bradesco (em 2013) e 150 filiais espalhadas pelo país (LOPES \& BRIGATTO, 2014). Além disso, respondia, em 2012, por 70\% do faturamento da empresa, com um montante de $\mathrm{R} \$ 736$ milhões (DRSKA, 2013).

Já a Scopus Soluções continuou pertencendo ao Bradesco. Desenvolve iniciativas de soluções digitais para o banco e possui um total de 700 funcionários. Segundo Maurício Minas (vice-presidente do Bradesco e presidente da Scopus) essa empresa possui um valor estratégico e possui apenas o banco como cliente, por controlar as suas informações de segurança. Além disso, a Scopus também controla $49 \%$ de uma joint venture com a empresa NCR para produção de ATMs na cidade de Manaus (LOPES \& BRIGATTO, 2014). 
Essa participação na fábrica da empresa estadunidense ocorreu no ano de 2011, pelo valor de U\$ 52 milhões. O objetivo principal era a produção de 30 mil caixas eletrônicos entre 2011 e 2015 (MOREIRA, 2011).

Desde 2013, a Scopus Soluções vem trabalhando no desenvolvimento de tecnologia conhecida como NFC (sigla em inglês de near field communication). Por meio dela, tornar-se-ia possível aos clientes do banco "programarem qualquer tipo de transação a partir dos seus aparelhos [celulares]", sendo que a operação se concluiria com a aproximação do celular de qualquer ATM (DRSKA, 2013).

\section{A topologia da Cobra}

Com a recuperação de seu faturamento, após a sua aquisição pelo Banco do Brasil, a empresa passou a apresentar resultados positivos de forma contínua. Em 1999 o faturamento foi de R\$ 207 milhões. Em 2000 a receita subiu para R\$ 297 milhões e o lucro para R\$ 15 milhões.

Em 2002, mantendo negócios com governos federais, estaduais e municipais, sua receita correspondeu a $\mathrm{R} \$ 414$ milhões de reais. No ano seguinte (2003), relançou seus projetos na área de computadores e ATMs, em função da busca do Banco do Brasil por modernizar seus equipamentos - por volta de 50 mil computadores. Segundo T. Fuoco (2002), buscando "ter escala e redução nos custos, a Cobra decidiu fabricar as máquinas em regime de OEM (via terceiros)".

Nesse sentido, passou a comprar chips da Intel e a negociar com a HP e Microsoft a montagem de 100 mil computadores com a sua marca. A produção local e benefícios fiscais eram vistos como fatores de redução de custos, que poderiam fazer com que as unidades produzidas chegassem de $10 \%$ a $15 \%$ mais baratas do que no mercado. Sua volta ao mercado de ATMs se deu com a contratação das empresas Perto, Itautec e Procomp [Diebold] para produção de um lote de 2,6 mil equipamentos para serem utilizados tanto no Banco do Brasil, como em outros bancos (FUOCO, 2002). 


\subsection{As diferenciações nos círculos de cooperação}

Embora as inciativas estatais na área de ciência e tecnologia tenham sido afetadas pelas políticas de cunho neoliberal dos anos 1990, não se pode dizer que elas deixaram de existir.

Em 1996, foram reestabelecidas algumas das políticas científicas e tecnológicas pelo governo federal. Nesse ano, houve a aprovação de um novo estatuto para a FINEP e a criação do Conselho Nacional de Ciência e Tecnologia (CCT), como órgão assessor da Presidência da República. Em 1997, houve a criação do CTPetro, o fundo setorial de petróleo, subordinado ao Fundo Nacional de Desenvolvimento Científico e Tecnológico (FNDCT), conforme destacou C. A. Pacheco (2007).

Foi a partir de 1999, no entanto, que medidas para a criação de novos Fundos Setoriais foram implementadas de forma sistemática, instituindo uma nova forma de atuação do Estado. Conforme destacou C. A. Pacheco (2007), entre 2000 e 2002, uma nova "base legal" para o fomento da atividade de Pesquisa e Desenvolvimento no país começou a ser estruturada, com a aprovação de 13 novos Fundos Setoriais: CTEnerg, CTTransp, CTHidro, CTEspacial, FNTTEL (Telecomunicações), CTEspacial, FVA (Fundo Verde Amarelo), CTInfo (que regulamentou e renovou incentivos para o setor de informática), CTInfra (para infraestrutura de pesquisa), CTBio (para a Biotecnologia), CTAgro (agronegócios), CTSaúde e o CTAeronáutico.

Essa organização institucional se deu por meio de um entendimento que, à exceção do FUNTTEL, todos deveriam estar ligados ao FNDCT, concebido então como um "fundo horizontal" que abrigaria diversos "fundos verticais", voltados para financiar e desenvolver atividades específicas. De forma complementar, outras 8 regulamentações foram aprovadas, visando ordenar e incentivar as atividades ligadas à ciência e tecnologia, como o abatimento em dobro no Imposto de Renda dos gastos que resultassem em patentes, o incentivo as parcerias público-privadas, flexibilização das instituições de pesquisa e destinação da receita do Imposto sobre Produtos Industrializados da Informática para o Fundo Verde-Amarelo (PACHECO, 2007). 
Esses novos fundos tiveram um papel importantíssimo na dotação de investimentos públicos para as atividades científicas e tecnológicas. Segundo C. A. Pacheco (2007), o FNDCT, que na década de 1980 movimentava valores na ordem de $\mathrm{R} \$ 300$ milhões por ano, em 1998 possuía um orçamento de R\$97,9 milhões. Desde então, começou um movimento crescente de captação de recursos para este Fundo: em 1999 aportou-se R\$ 171,4 milhões, chegando em R \$ 348,2 milhões no ano 2000 (mais que o dobro), 725 milhões de reais em 2001 até atingir a marca de $\mathrm{R} \$ 1,455$ bilhões de reais em 2004 (PACHECO, 2007).

A partir de 2003, com essa experiência de criação de Fundos Setoriais, partiu-se para a estruturação de um Sistema Nacional de Inovação, tendo como referência as medidas expostas no documento DPITCE. Além dos pontos já discutidos no subcapítulo anterior, estabeleceu-se que deveria ocorrer uma

articulação de agentes voltados ao processo de inovação do setor produtivo, em especial: empresas, centros de pesquisa públicos e privados, instituições de fomento e financiamento ao desenvolvimento tecnológico, instituições de apoio à metrologia, propriedade intelectual, gestão tecnológica e gestão do conhecimento, instituições de apoio à difusão tecnológica (DPITCE, 2003).

Considerou-se então que, para organizar o referido Sistema Nacional de Inovação, seria forçoso (DPITCE, 2003): i) harmonizar a base legal; ii) definir sua institucionalidade (atores, competências, mecanismos de decisão, modelo de financiamento e gestão, entre outros); e iii) definir suas prioridades.

Sobre este ponto caberia a "criação e fortalecimento de instituições públicas e privadas de pesquisa e serviços tecnológicos, inclusive visando a difusão de tecnologias e a extensão tecnológica", organizando "sistemas setoriais de inovação e difusão tecnológica, isto é, redes de instituições especializadas em temas, setores, cadeias produtivas". Também se observou a importância de "ampliar o debate nacional, mediante a retomada da prática de conferências nacionais periódicas", organizando "a discussão em torno de temas estratégicos como biotecnologia, novos materiais, tecnologias de informação e comunicação, energia e meio ambiente (recursos hídricos, biodiversidade e florestas)".

Por fim, o documento, estabeleceu algumas opções estratégicas da política industrial e tecnológica, concentrando "esforços em algumas áreas intensivas em 
conhecimento". Estas opções estratégicas deveriam estar focadas em atividades que:

a) apresentam dinamismo crescente e sustentável; b) são responsáveis por parcelas expressivas dos investimentos internacionais em Pesquisa e Desenvolvimento; c) abrem novas oportunidades de negócios; d) relacionam-se diretamente com a inovação de processos, produtos e formas de uso; e) promovem o adensamento do tecido produtivo f) são importantes para o futuro do país e apresentam potencial para o desenvolvimento de vantagens comparativas dinâmicas (DPITCE, 2003).

Esses eram os casos, para a DPITCE, dos semicondutores, software, fármacos e medicamentos e bens de capital.

As ações nesses casos pressupõem um complexo e sofisticado conjunto de instrumentos, com forte articulação com outras políticas públicas. Por exemplo, há nítida relação entre as políticas para semicondutores, software e bens de capital com a política de infraestrutura (energia, logística e saneamento, e telecomunicações, respectivamente). Também é forte a relação de fármacos e medicamentos com a política de saúde. Portanto, essas políticas requerem ação governamental mais intensa, bem como a articulação entre instituições públicas e destas com o setor privado, nacional e estrangeiro (DPITCE, 2003).

Tendo em vista a importância de tais diretrizes, a serão apresentadas as medidas em torno dos semicondutores e dos softwares. No caso dos semicondutores, foi diagnosticado que estes eram "a mola propulsora do complexo eletrônico", englobando atividades nas áreas de eletrônica de consumo e informática, mas também "as telecomunicações, controles industriais, indústria aeroespacial, saúde, agropecuária e aplicações militares" (DPITCE, 2003). O diagnóstico desse ramo foi preciso e mostra o que significou a abertura de mercado da década de 1990:

O Brasil já viveu um estágio avançado no segmento. No início dos anos 70, o país dispunha de um laboratório de classe mundial e encontrava-se bem próximo do estado da arte em pesquisa de circuitos integrados. No final dos anos 80, havia 23 companhias no país, a maioria das quais grandes grupos internacionais; hoje, esse número está limitado a 4 firmas. A retomada da produção de semicondutores no Brasil é um desafio. As barreiras de entrada são grandes; os países atualmente produtores ofereceram condições vantajosas tanto em termos de investimento quanto em termos de incentivos e subsídios. Não se trata, para o país, apenas de um problema de déficit comercial, mas, sobretudo, de capacitação em circuitos integrados, que envolve engenharia e conhecimentos sofisticados. Além de os semicondutores serem parte da evolução para a nanotecnologia, eles se encontram em constante processo de renovação, criando nichos de mercados relevantes (DPITCE, 2003).

A principal recomendação para esse ramo, foi a implementação de "um programa de governo focado tanto em atração de investimento quanto em desenvolvimento de competências e formação de pessoal qualificado", contando 
com "os estudos desenvolvidos pelo BNDES para a atração de investimento em CIs [circuitos integrados] e as contribuições resultantes dos debates, feitos no fim de 2002, envolvendo técnicos do MCT, empresários e pesquisadores".

Já no que diz respeito ao software, o documento partia do seguinte diagnóstico:

O software brasileiro tem pela frente o desafio da inserção e competitividade internacional em produtos e serviços. O país tem o sétimo maior mercado de software do mundo, com vendas de US\$ 7,7 bilhões em 2001, importa o equivalente a US\$ 1 bilhão e exporta em torno de US\$ 100 milhões. Maior da América Latina, o mercado brasileiro apresentou um crescimento anual médio de $11 \%$ entre 1995 e 2002, cerca de cinco vezes maior do que a expansão do PIB no período. É o segmento que mais cresce dentro da indústria brasileira de Tecnologia da Informação (hardware, serviços e software). As empresas de desenvolvimento de programas, processamento e bancos de dados passaram de 4.300, em 1994, para $5.400 \mathrm{em} 2000$ (DPITCE, 2003).

No entanto, foi observado que alguns fatores dificultavam um maior desenvolvimento desse ramo, como "a ausência de uma estratégia industrial focada, a falta de uma imagem do software brasileiro reconhecida no mercado internacional e dificuldades de financiamento". Segundo o documento,

Para explorar as oportunidades existentes no mercado mundial, o Brasil apresenta alguns pontos fortes, como flexibilidade e criatividade de suas empresas; sofisticação de seus mercados-alvo, a exemplo de financeiro e telecomunicações; e agressiva experimentação no mercado de produtos, em particular quando comparado com a China e a Índia. Também apresenta pontos fracos, entre os quais estão o insuficiente apoio à exportação; a limitada experiência internacional das empresas; problemas de acesso ao mercado do setor público; insuficiência do mercado de capitais de risco; ausência de empresas-líderes e existência de muitas empresas de pequeno porte, pouco cooperativas; a ausência de um modelo ou imagem a que se possa associar a capacidade do software brasileiro no exterior e pouca expressão das exportações (DPITCE, 2003).

Diante de tais diretrizes, o governo passou a atuar na estruturação do já mencionado Sistema Nacional de Inovação, com a instituição do Decreto $n^{\circ} 4.728$, em 2003, que aprovou o estatuto e o quadro demonstrativo dos cargos do CNPq. No ano seguinte, foi aprovada a Lei $n^{\circ} 10.973$, conhecida como a "Lei da Inovação", além da Lei $\mathrm{n}^{\mathrm{o}}$ 11.080, que criou o Conselho Nacional de Desenvolvimento Industrial - órgão colegiado regulamentado pelo Decreto no 5.353 -, definindo como sua atribuição propor ao presidente da República políticas nacionais e medidas específicas destinadas a promover o desenvolvimento industrial do país. Em 2005, houve Lei no 11.196 (chamada "Lei do Bem"), que estabeleceu 
incentivos fiscais à investigação tecnológica e à inovação e o Decreto $\mathrm{n}^{0} 5.563$, de 11/10/2005, que regulamentou a Lei da Inovação.

No Quadro 6, apresentado a seguir, busca-se sintetizar as ações estruturantes do Estado brasileiro, de modo a fundamentar o entendimento do seu papel na instituição de uma cooperação estendida para as atividades industriais, científicas e tecnológicas.

\section{Quadro 6 - Quadro-síntese das principais ações do Estado (1960-2012) para a indústria, ciência e tecnologia}

\begin{tabular}{|c|c|}
\hline \multirow{7}{*}{$\begin{array}{l}\text { Anos 1960-1980: } \\
\text { Expansão da } \\
\text { Capacidade } \\
\text { Produtiva }\end{array}$} & Criação do CNPq \\
\hline & Criação da FINEP \\
\hline & I e II PND \\
\hline & Programa Brasileiro de Desenvolvimento Científico e Tecnológico \\
\hline & Lei da Informática \\
\hline & I Plano Nacional de Informática \\
\hline & Criação do Ministério da Ciência e Tecnologia \\
\hline \multirow{5}{*}{$\begin{array}{l}\text { Anos 1990: } \\
\text { Competividade, } \\
\text { eficiência e } \\
\text { qualidade }\end{array}$} & Diretrizes de Política Industrial e de Comércio Exterior (PICE) \\
\hline & Programa de Competitividade Industrial \\
\hline & Programa Brasileiro de Qualidade e Produtividade \\
\hline & $\begin{array}{l}\text { Lei de Informática (1991) - incentivos à P\&D e redução de IPI para o setor de } \\
\text { eletrônica e Informática; alterada em } 1997 \text {. }\end{array}$ \\
\hline & Financiamentos do BNDES \\
\hline \multirow{11}{*}{$\begin{array}{l}\text { Anos 2000: } \\
\text { Inovação e } \\
\text { crescimento } \\
\text { sustentado }\end{array}$} & Aprofundamento e multiplicação dos Fundos Setoriais \\
\hline & Política Industrial, Tecnológica e de Comércio Exterior (PITCE) \\
\hline & Criação do Conselho Nacional de Desenvolvimento Industrial \\
\hline & Criação da Agência Brasileira de Desenvolvimento Industrial \\
\hline & Lei da Inovação \\
\hline & Lei do Bem \\
\hline & Plano de Ação em CT\&I para o Desenvolvimento (PACTI) \\
\hline & Política de Desenvolvimento Produtivo (PDP) \\
\hline & Programa Brasil Maior \\
\hline & Estratégia Nacional de Ciência, Tecnologia e Inovação \\
\hline & Financiamento do BNDES (Fundo Tecnológico, por exemplo) \\
\hline
\end{tabular}
Fonte: Elaboração própria, com base em Z. Miranda e E. Mirra (2012).

A Itautec foi a empresa do circuito espacial de produção de ATMs mais beneficiada nesse processo de aprofundamento dos círculos de cooperação ligados ao Estado. Entre 2004 e 2011, foram submetidos e aprovados cinco projetos pela FINEP, com participação dessa empresa, representando um aporte total de R\$ 135.240.919,00 para projetos relacionados a atividades de pesquisa e desenvolvimento tecnológico - Quadro 7. 
Quadro 7 - Círculos de cooperação estatal: projetos contratados pela FINEP, com participação da empresa Itautec (2004-2011)

\begin{tabular}{|c|c|c|c|c|}
\hline Convênio & Vigência & Modalidade & Instituições Participantes & $\begin{array}{c}\text { Valor Liberado para } \\
\text { o projeto }\end{array}$ \\
\hline $\begin{array}{l}\text { Processamento } \\
\text { paralelo de } \\
\text { consultas no } \\
\text { sistema de banco } \\
\text { de dados } \\
\text { POSTGRES }\end{array}$ & 2004-2006 & $\begin{array}{c}\text { Não } \\
\text { Reembolsável }\end{array}$ & $\begin{array}{l}\text { Fundação Coordenação de } \\
\text { Projetos, Pesquisa e Estudos } \\
\text { Tecnológicos COPPTEC } \\
\text { (Proponente), Universidade } \\
\text { Federal do Rio de Janeiro } \\
\text { (Executor) e ITAUTEC S.A. } \\
\text { (Interveniente) }\end{array}$ & $\mathrm{R} \$ 179.475,00$ \\
\hline $\begin{array}{l}\text { Desenvolvimento } \\
\text { de P\&D e } \\
\text { Laboratório de } \\
\text { Protótipos e } \\
\text { Testes }\end{array}$ & 2004-2006 & Reembolsável & $\begin{array}{l}\text { ITAUTEC S.A. (Proponente e } \\
\text { Executor) }\end{array}$ & $\mathrm{R} \$ 34.735 .383,00$ \\
\hline $\begin{array}{l}\text { Rede } \\
\text { Cooperativa de } \\
\text { Desenvolvimento } \\
\text { e Usos do } \\
\text { BRAMs }\end{array}$ & 2005-2007 & $\begin{array}{c}\text { Não } \\
\text { Reembolsável }\end{array}$ & 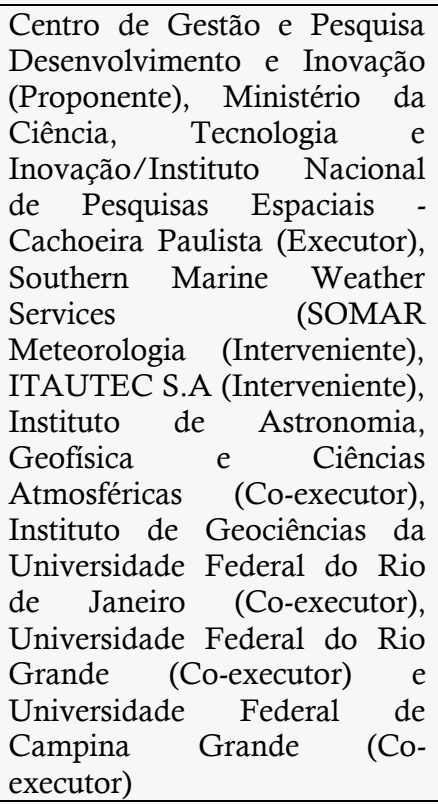 & $\mathrm{R} \$ 242.150,00$ \\
\hline $\begin{array}{l}\text { Desenvolvimento } \\
\text { de uma } \\
\text { autoridade de } \\
\text { estampilhamento } \\
\text { temporal }\end{array}$ & 2004-2007 & $\begin{array}{c}\text { Não } \\
\text { Reembolsável }\end{array}$ & $\begin{array}{l}\text { Núcleo de Segurança e Redes } \\
\text { de Alta Velocidade - EPUSP } \\
\text { (Proponente e Executor), } \\
\text { Rainbow Technologies do } \\
\text { Brasil Ltda (Interveniente) e } \\
\text { ITAUTEC S.A }\end{array}$ & $\mathrm{R} \$ 83.911,00$ \\
\hline $\begin{array}{l}\text { Programa de } \\
\text { Pesquisa e } \\
\text { Desenvolvimento } \\
\text { da Itautec para } \\
2009 \text { e } 2010\end{array}$ & 2009-2011 & Reembolsável & $\begin{array}{l}\text { ITAUTEC S.A. (Proponente e } \\
\text { Executor) }\end{array}$ & $\mathrm{R} \$ 100.000 .000,00$ \\
\hline
\end{tabular}

Fonte: Elaboração Própria, com base em informações disponibilizadas no sítio eletrônico da FINEP.

Uma outra forma de atuação estatal no estabelecimento de laços funcionais entre lugares e atividades econômicas foi por meio das estratégias promovidas pelo Banco Nacional de Desenvolvimento Econômico e Social (BNDES). Esse é um elemento importante para a explicação do processo de expansão dos mercados para o circuito espacial de produção de ATMs na América Latina. No ano de 2007, por exemplo, o presidente do BNDES declarou a necessidade de se aproveitar da escala 
do mercado nacional e sul-americano para acelerar o dinamismo das cadeias manufatureiras de produção de tecnologias de informação e comunicação, dentro das quais os sistemas técnicos de automação bancária se inserem.

Mais uma vez, a Itautec foi beneficiada, com a aprovação, pelo BNDES, de um financiamento na ordem de $\mathrm{R} \$ 142$ milhões, destinados à pesquisa, ao desenvolvimento e à inovação em produtos e processos, ao aumento da capacidade produtiva e à expansão da atividade internacional com a aquisição da empresa estadunidense Tallard Technologies - distribuidora de produtos de informática, automação e serviços (BNDES, 2007).

Dessa forma, esses círculos de cooperação abrangem uma vasta gama de interações espaciais por meio da elaboração e da destinação de recursos a projetos, dos quais participaram órgãos de financiamento, empresas, universidades e institutos de pesquisa estabelecendo solidariedades funcionais entre diversos Estados da formação socioespacial brasileira, como São Paulo, Rio de Janeiro e o Distrito Federal.

\section{Os círcullos de cooperação corporativos: a centralidade da Febraban}

$\mathrm{O}$ poder dos bancos vai além da sua capacidade de angariar recursos $\mathrm{e}$ exercer o controle dos fluxos de capitais na economia. Como destacou A. Minella (2009, p. 281) a expansão e a atuação simultânea dos bancos estrangeiros nas associações de classe locais dos diferentes países da América Latina tem sido um aspecto de grande importância nas análises da internacionalização dos bancos nessa região do mundo:

O processo de internacionalização do sistema financeiro na América Latina se expressa também pela significativa presença de instituições estrangeiras nas direções dos órgãos de representação de classe em muitos países, incluindo o Brasil, destacando-se grandes grupos internacionais dos Estados Unidos e da Europa. Citibank (Citigroup), Banco Bilbao Vizcaya Argentaria (BBVA) e o Banco Santander Central Hispânico (BSCH) constituem os exemplos mais significativos. Em 2000 e em 2006, cada um deles atuava de forma simultânea em associações de classe do setor financeiro em sete países. No caso do Citibank, a atuação se estende a 11 associações, das quais cinco são do Brasil (MINELLA, 2009, p. 281).

Assim, seria preciso considerar, ao menos como hipótese de pesquisa, o poder do que chamou de "redes transassociativas", que, segundo o autor, "se formam a partir da participação simultânea de uma mesma empresa ou grupo 
econômico - no nosso caso, uma instituição, um conglomerado ou um grupo financeiro - em várias associações de classe, em diferentes países" (MINELLA, 2009, p. 281).

Seu significado poderia ser interpretado como um indicativo do reforço de "assimetrias de poder corporativo no sistema financeiro internacional", da expansão da "possibilidade de posicionamento e atuações coordenadas na América Latina", da criação "um canal privilegiado de fluxo de informação especialmente para as grandes instituições financeiras internacionais" e, por fim, do fato de que seria "por meio das associações de classe local, [que] os bancos estrangeiros internalizam seus interesses e ganham representatividade nas negociações com o governo e com outros segmentos empresariais" (MINELLA, 2009, p. 281).

No caso brasileiro, essas redes, que extrapolam as referidas ações dos bancos estrangeiros, permitem um aprofundamento da relação dos grandes bancos com o Estado, representado, segundo A. Minella (2009), por, pelo menos, seis fatores:

1. Compra de títulos da dívida pública;

2. Influência em ações e decisões do Banco Central, com o trânsito de "duas vias" entre membros da direção dos bancos comerciais para cargos de presidência e direção do Banco Central e desses para aqueles;

3. Importância do papel do poder legislativo na democracia brasileira e a questão do financiamento eleitoral;

4. Organizações político-ideológicas mantidas por organizações ou empresários;

5. Influência em decisões governamentais e reforço do poder das instituições financeiras privadas;

6. Participação na privatização dos bancos públicos;

Um exemplo categórico dessa atuação junto ao governo diz respeito à formação e consolidação do Novo Sistema de Pagamentos Brasileiro (SPB). Esse sistema teve como base as experiências acumuladas pelo Banco Central para que se evitasse o caos no sistema financeiro, popularmente chamado de "bug do milênio". Conforme narrou I. ANGELO (2007, p. 128), em 1999, foi instituído "um comitê 
conjunto de instituições financeiras e passou a acompanhar os processos de adaptação e entrosamento de sistemas".

A partir daí, foi criada "uma câmara de compensação à parte, fictícia", para que se realizasse, sob a coordenação do então superintendente da Febraban, Wilson Gutierrez, "um grande teste de programação em rede, envolvendo o Banco Central, a Tecban (administradora do Banco 24 horas), a Credicard, a Central de Liquidação e Custódia de Títulos Privados (Cetip), a Associação Nacional dos Bancos de Investimento (Anbid) e a Câmara de Compensação do Banco do Brasil" (ANGELO, 2007, p. 128).

Esse teste, segundo I. Angelo (2007, p. 128) "levou meses para ser concluído, a custo elevado" e abrangeu "a compensação de cheques, DOC, cobrança, compra e venda de títulos e câmbio e transações com cartões de crédito". Sob a fiscalização do Banco Central foi constatado que os testes "tiveram êxito total, e o sistema financeiro pôde virar para o ano 2000 sem problemas" (ANGELO, 2007, p. 128). A partir dessa experiência, foi criado o comitê de gestores do Sistema de Pagamentos Brasileiro e, com a instituição do Sistema de Transferência de Reservas, foi estruturado o novo SPB (idem, 2007) ${ }^{39}$.

Essa participação ativa nas representações de classe tem sido, dessa maneira, uma estratégia fundamental para ação dos bancos, não apenas pelas ações em defesa de seus interesses diretos, como, igualmente, para um direcionamento no sentido de promover, na sociedade e entre empresas de tecnologia, um conjunto de ideias e práticas para torná-las mais difundidas. Esse é um dos principais pontos da estruturação dos círculos de cooperação para as empresas do circuito espacial de produção de ATMs, que, além de se organizar em torno de um mercado consolidado e articulado, podem contar com estudos promovidos pela Febraban, como a "Pesquisa Febraban de Tecnologia Bancária" e as apresentações "O setor bancário em números" que compilam anualmente informações e promovem a publicização dos direcionamentos promovidos pelos bancos.

Ao se debruçar sobre tais estudos, F. Contel (2016) evidenciou que há uma "visão da Febraban", não apenas sobre o que significa a bancarização da

39 A organização e funcionamento do novo SPB será discutida com mais detalhes no sub-capítulo posterior. 
população, como também sobre os sentidos dos usos dos fixos e serviços bancários e dos investimentos em sistemas técnicos automatizados. Segundo esse autor, a análise das informações contidas nos documentos da Febraban permitiria constatar, ainda, que "as técnicas da informação têm se tornado cada vez mais o 'alicerce fundamental' para indústria de serviços financeiros" (CONTEL, 2016, p. 52). Seria possível, nesse sentido, identificar um forte peso dos "sistemas técnicos disponíveis para os consumidores de serviços financeiros" na explicação da "financeirização do território nacional" (CONTEL, 2016, p. 52):

O acesso e o uso do sistema financeiro, com essa nova base material, levou tanto a um crescimento da base de clientes bancários, como a uma intensificação do uso destes serviços, já que as tecnologias da informação tornam as transações financeiras - sobretudo aquelas que não envolvem a movimentação de recursos muito mais ágeis e baratas para serem feitas

Esses documentos da Febraban contribuem, dessa forma, para consolidar estratégias ligadas à sua atuação na formação socioespacial brasileira, estimulando um entendimento comum sobre os temas de interesse dos bancos, assim como um alinhamento das expectativas dos "clientes" e dos "fornecedores" de tecnologia. Para isso, a referida Federação faz uso também a Revista CIAB-Febraban, de frequência trimestral, que permite a divulgação de novos produtos e serviços oferecidos pelos bancos e pelas indústrias de ATMs, além de artigos que acompanham o movimento do "mercado" mais proximamente.

Por fim, o estabelecimento dos círculos de cooperação se realiza com o Congresso Internacional de Automação Bancária (CIAB-Febraban) - Quadro 8 -, que durante os anos 2000 tornou-se o mais importante da América Latina nesse ramo. Em entrevista, tanto o diretor de marketing da Diebold, quanto o assessor de imprensa da OKI Brasil, foram categóricos ao dizer que esse é o evento mais importante para as empresas desse circuito espacial de produção. Como pode ser visto no referido quadro, nesses eventos tem-se discutido temáticas amplas, mas que, em geral, gravitam em torno de questões sobre a inserção dos serviços bancários na sociedade e sobre tendência de implantação de novos sistemas técnicos bancários. A compreensão dos hábitos de consumo das diferentes gerações é um aspecto essencial para organização desses sistemas, daí em muitos anos aparecerem questões relativas à comunicação da "nova geração" com o banco, ou o 
crescimento do uso de novas tecnologias e como poderiam ser ofertados serviços financeiros por meio desses dispositivos.

\section{Quadro 8 - Quadro síntese dos temas e questões discutidas nos Congressos Internacionais de Automação Bancária (CIAB-FEBRABAN) entre 2000 e 2015, por ano}

\begin{tabular}{cl}
\hline Ano & \multicolumn{1}{c}{ Principais questões discutidas no evento } \\
\hline 2000 & $\begin{array}{l}\text { "Participantes discutiram a posição do Brasil no mercado internacional. À época, o } \\
\text { bilhões de documentos por ano para 42 milhões de portadores de talões. Nesse ano, a } \\
\text { Federação divulgou que 67\% das operações foram automatizadas." }\end{array}$ \\
\hline 2001 & $\begin{array}{l}\text { "marcou a discussão sobre certificação digital e técnicas do e-business e e-commerce } \\
\text { aplicadas ao mundo financeiro" }\end{array}$ \\
\hline 2002 & $\begin{array}{l}\text { "os debates giraram em torno da modernização da infraestrutura da tecnologia da } \\
\text { informação, tanto no back office como em outros setores." }\end{array}$ \\
\hline 2003 & $\begin{array}{l}\text { "Expositores e patrocinadores debateram risco operacional, fraudes, tendências de } \\
\text { tecnologia e mercado e perspectivas para a redução de custos" }\end{array}$ \\
\hline $\mathbf{2 0 0 4}$ & $\begin{array}{l}\text { "o congresso abordou as estratégias que as instituições financeiras deveriam adotar } \\
\text { paraterem mais correntistas, distribuir melhor o crédito e melhorar o desempenho } \\
\text { financeiro. Compartilhamento de recursos bancários, inclusão e certificação digital, } \\
\text { alinhamento de negócios e TI, além de telecomunicações também estiveram no centro } \\
\text { das discussões." }\end{array}$ \\
\hline
\end{tabular}

2005 "Entre os assuntos discutidos estavam a imagem dos bancos na sociedade, a produção em offshore e outsourcing, bancarização, certificação digital e software livre"

\begin{tabular}{cl}
\hline 2006 & "debates sobre a economia digital" \\
\hline 2007 & $\begin{array}{l}\text { "grande crescimento de alternativas em internet, telefonia e autoatendimento } \\
\text { disponibilizadas pelas instituições financeiras para seus clientes" }\end{array}$ \\
\hline 2008 & $\begin{array}{l}\text { "debates para aprofundar assuntos como green IT, governança, mobilidade e } \\
\text { certificação" }\end{array}$ \\
\hline 2009 & $\begin{array}{l}\text { "A trajetória dos bancos brasileiros foi o destaque do Ciab desse ano com debates sobre } \\
\text { a bancarização. Pesquisa apresentada no evento revelou que o País tinha alcançado } \\
125,7 \text { milhões de contas correntes no ano de 2008, e um total de } 43 \text { milhões de } \\
\text { internautas." }\end{array}$ \\
\hline 2010 & $\begin{array}{l}\text { "As discussões no fórum giraram em torno de questões como a preparação dos bancos } \\
\text { nacionais e internacionais para atender e entender os hábitos dos clientes desta } \\
\text { geração" }\end{array}$ \\
\hline 2011 & $\begin{array}{l}\text { " o Ciab promoveu o debate sobre a tecnologia além da web. O objetivo dos } \\
\text { organizadores foi explorar a discussão de novas dimensões da internet." }\end{array}$ \\
\hline 2012 & $\begin{array}{l}\text { "Nesse ano, os participantes discutiram as causas e os investimentos necessários para } \\
\text { suportar essa tendência. Entre os destaques estava o crescimento de transações por } \\
\text { dispositivos móveis." }\end{array}$ \\
\hline 2013 & $\begin{array}{l}\text { "abordou as novas demandas do setor, tendências e soluções de ajustes dos modelos de } \\
\text { negócios das instituições" }\end{array}$ \\
\hline $\mathbf{2 0 1 4}$ & $\begin{array}{l}\text { "Assuntos como a maneira pela qual a nova geração se comunica com o banco, } \\
\text { tendências da internet e mobile banking, bem como a evolução do social banking e } \\
\text { canais eletrônicos intuitivos estiveram na pauta do evento." }\end{array}$ \\
\hline 2015 & $\begin{array}{l}\text { "TI e Telecom, Segurança da Informação, Meios de Pagamento, Seguros, Bancos de } \\
\text { Investimentos e Mercado de Capitais" }\end{array}$ \\
\hline
\end{tabular}

Fonte: Mompean, A. "Ciab-FEBRABAN: 25 anos promovendo a tecnologia nos bancos". Revista Ciab Febraban, no 56, abril/2015. pp. 15-19. 


\subsection{Bancarização da população e a situação dos ATMs na atual geografia dos fixos bancários}

A expansão do sistema bancário nos anos 1990, como foi visto, foi pautada em novos processos de centralização e de concentração, dessa vez caracterizado pela diminuição da participação dos bancos públicos e aumento dos bancos estrangeiros. Um dado a ser acrescentado diz respeito às dinâmicas dos 50 maiores bancos no Brasil entre 1995 e 2000 - Tabela 4 e Tabela 5.

Tabela 4 - Centros de gestão no território dos 50 maiores bancos no Brasil (dez/1995)

\begin{tabular}{|l|c|c|c|}
\hline \multicolumn{1}{|c|}{ Cidades } & Número de Sedes & Ativo Total & No de Agências Controladas \\
\hline SÃO PAULO & 25 & 166.713 .972 & 4.288 \\
\hline BRASÍLIA & 3 & 161.462 .218 & 5.539 \\
\hline OSASCO & 1 & 28.847 .096 & 1.856 \\
\hline CURITIBA & 2 & 19.724 .592 & 1.766 \\
\hline RIO DE JANEIRO & 7 & 18.682 .966 & 574 \\
\hline PORTO ALEGRE & 2 & 14.436 .554 & 228 \\
\hline BARUERI & 2 & 12.701 .714 & 87 \\
\hline JUIZ DE FORA & 1 & 6.623 .317 & 181 \\
\hline FORTALEZA & 1 & 5.571 .754 & 702 \\
\hline BELO HORIZONTE & 3 & 5.122 .221 & 274 \\
\hline SALVADOR & 1 & 1.623 .942 & 104 \\
\hline FLORIANÓPOLIS & 1 & 1.591 .900 & 16.123 \\
\hline BELÉM & 1 & 1.014 .199 & 570 \\
\hline TOTAL & 50 & 444.116 .445 & $\mathrm{M}$ \\
\hline
\end{tabular}

Fonte: Elaboração própria com base nos dados fornecidos pelo Banco Central - 50 Maiores Bancos e o Consolidado do Sistema Financeiro Nacional.

Tabela 5 - Centros de gestão no território dos 50 maiores bancos no Brasil (dez/2000)

\begin{tabular}{|l|c|c|c|}
\hline \multicolumn{1}{|c|}{ Cidades } & Número de Sedes & Ativo Total & No de Agências Controladas \\
\hline SÃO PAULO & 31 & 350.974 .789 & 5.490 \\
\hline BRASÍLIA & 3 & 265.758 .606 & 4.885 \\
\hline OSASCO & 1 & 83.448 .796 & 2.589 \\
\hline RIO DE JANEIRO & 5 & 32.757 .799 & 477 \\
\hline CURITIBA & 1 & 21.556 .682 & 985 \\
\hline SALVADOR & 2 & 12.698 .690 & 368 \\
\hline FORTALEZA & 1 & 8.806 .516 & 175 \\
\hline PORTO ALEGRE & 1 & 7.670 .222 & 359 \\
\hline BELO HORIZONTE & 1 & 2.856 .648 & 198 \\
\hline BELÉM & 1 & 2.354 .061 & 83 \\
\hline VITÓRIA & 1 & 2.091 .248 & 256 \\
\hline FLORIANÓPOLIS & 1 & 1.532 .632 & 152 \\
\hline GOIÂNIA & 1 & 1.148 .527 & 16.103 \\
\hline TOTAL & 50 & 793.655 .216 & \\
\hline
\end{tabular}

Fonte: Elaboração própria com base nos dados fornecidos pelo Banco Central - 50 Maiores Bancos e o Consolidado do Sistema Financeiro Nacional. 
Os dados das tabelas anteriores permitem-nos constatar que, entre dezembro de 1995 e dezembro de 2000, houve um aumento de 78\% dos ativos totais dos 50 maiores bancos no país, sendo que os maiores percentuais foram daqueles situados em: Salvador, com crescimento total de 681\%, Osasco (registrando aumento de 189\%), Belém (132\%) e São Paulo (110\%). Houve, no entanto, registro de queda dos ativos totais dos bancos localizados em Porto Alegre (46\%), Belo Horizonte (43\%) e Florianópolis (3\%).

No que diz respeito ao número de sedes presentes e agências controladas, houve diminuição em $66 \%$ e $81 \%$, respectivamente, em Belo Horizonte; em 50\% e $44 \%$ em Curitiba (respectivamente); e 55\% e $37 \%$ em Porto Alegre. No Rio de Janeiro, houve queda no número de sedes (38\%), e aumento no número de agências sob seu controle (28\%), ao passo que Brasília reduziu o controle de $11 \%$ do número de agências e manteve-se estável no número de sedes. Osasco também se manteve estável nesse quantitativo, mas registrou aumento de $38 \%$ no número de agências controladas. Salvador registrou um aumento de $100 \%$ no número de sedes (passando a abrigar 2 dos 50 maiores bancos) e 111\% no número de agências. Em São Paulo houve o maior acréscimo no número de sedes (somando 6 em relação a 1995), registrando uma alta de $24 \%$; já as agências sob seu comando aumentaram em $28 \%$.

Do ponto de vista da gestão do território algumas situações, portanto, podem ser reconhecidas:

1. São Paulo, que já era o principal centro de gestão bancário do território nos finais dos anos 1980 (CORRÊA, 1989), reforçou sua posição na rede urbana nacional: se em 1995, possuía 50\% das sedes, $37 \%$ dos ativos totais e controlava $26 \%$ do total de agências dos 50 maiores bancos instalados na formação socioespacial brasileira, em 2000 ela passou a abrigar, respectivamente, $62 \%$, 44\% e 34\%. São Paulo também era o principal centro de gestão dos bancos privados nacionais e estrangeiros;

2. Brasília, embora possuindo um número muito inferior de sedes, se constituía como outro importante centro de gestão bancário, concentrando 36\% dos ativos totais em 1995 e 33\% em 2000; e 
controlando 34\% do total de agências em 1995 e 30\% em 2000. Nessa cidade estavam os maiores bancos públicos nacionais à época, a Caixa Econômica Federal e Banco do Brasil;

3. O único banco de Osasco (Bradesco) controlava 6\% dos ativos e 11\% das agências em 1995, aumentando sua participação para 10\% e 16\%, respectivamente, em 2000;

4. Esses três centros de gestão controlavam, nos anos $2000,88 \%$ dos ativos e $81 \%$ das agências em relação aos 50 maiores bancos instalados no país;

5. O Rio de Janeiro, que possuía $14 \%$ das sedes, $4 \%$ dos ativos e $2 \%$ das agências dos 50 maiores bancos sob seu controle em 1995, passou a ter $10 \%, 4 \%$ e $5 \%$ em 2000 .

6. Curitiba e Belo Horizonte perderam sua participação nos ativos totais em relação a esse grupo de bancos, com redução da primeira de 4\% em 1995 para 2\% em 2000; e de 1\% em 1995 para 0,35\% em 2000, da segunda cidade.

Nos anos 2000, a concentração e a centralização nos centros de gestão bancários no território brasileiro sofreram algumas modificações. Entre 2000 e 2011, os 50 maiores bancos aumentaram seus ativos em $519 \%$ e o número de agências sob seu controle em 30\%. - Tabela 6.

Tabela 6 - Centros de gestão no território dos 50 maiores bancos no Brasil (dez/2011)

\begin{tabular}{|l|c|c|c|}
\hline \multicolumn{1}{|c|}{ Cidades } & Número de Sedes & Ativo Total & $\mathbf{N}^{\mathbf{o}}$ de Agências Controladas \\
\hline SAO PAULO & 28 & 1.805 .992 .453 & 6.824 \\
\hline BRASILIA & 4 & 1.466 .575 .213 & 7.568 \\
\hline RIO DE JANEIRO & 4 & 673.866 .373 & 17 \\
\hline OSASCO & 1 & 666.320 .079 & 8.643 \\
\hline CURITIBA & 1 & 146.593 .297 & 453 \\
\hline PORTO ALEGRE & 5 & 71.775 .951 & 210 \\
\hline BELO HORIZONTE & 3 & 32.368 .365 & 188 \\
\hline FORTALEZA & 1 & 26.435 .588 & 133 \\
\hline VITORIA & 1 & 10.119 .254 & 2 \\
\hline BELEM & 1 & 9.871 .604 & 21.024 \\
\hline BETIM & 1 & 5.149 .607 & 118 \\
\hline TOTAL & 50 & 4.915 .067 .784 & . \\
\hline
\end{tabular}

Fonte: Elaboração própria com base nos dados fornecidos pelo Banco Central - 50 Maiores Bancos e o Consolidado do Sistema Financeiro Nacional.

A cidade de São Paulo continuou na posição de liderança em 2011, com um aumento de $414 \%$ nos ativos totais e em $24 \%$ nas agências, em relação a 2000. Mas 
perdeu 3 sedes desse grupo de bancos, registrando um total de 28 (56\% em relação ao total), que controlavam $56 \%$ dos ativos e $32 \%$ das agências - em relação ao total dos 50 maiores bancos existentes no território nacional.

Nesses 11 anos, os 4 bancos sediados em Brasília aumentaram em 451\% os seus ativos totais e em $54 \%$ seu número de agências, controlando $35 \%$ do total de agências e 29\% do total de ativos dos 50 maiores bancos em 2011. Osasco aumentou em $698 \%$ o seu total de ativos e em $79 \%$ o número de agências sob seu controle, situando-se com o controle de $22 \%$ do total de agências desse grupo de bancos e de $13 \%$ em relação ao total de ativos.

Essas três cidades tiveram uma queda de 8 pontos percentuais em relação ao controle total de ativos, dominando $80 \%$ do total; no que diz respeito ao controle de agências houve aumento de 10 pontos percentuais no período considerado, tendo $91 \%$ do total em 2011. O principal motivo para essa redução foi a ascensão do Rio de Janeiro, com um aumento de $1.957 \%$ do total de ativos sob seu controle - o maior aumento do período -, com $14 \%$ dos ativos dos 50 maiores bancos existentes no país em 2011; ao mesmo tempo, reduziu em 2\% o número de sedes sob seu controle e em 460 o número de agências, tendo apenas 17 agências sob seu controle desse grupo de bancos.

Curitiba, com apenas um banco nessa lista, registrou um aumento de 580\% dos ativos e de $2 \%$ no número de agências, aumentando sua participação relativa para um valor aproximado de 3\% e 4\%, respectivamente, em 2011. Porto Alegre registrou um aumento de 4 sedes, possuindo um total de 5 dos 50 maiores de 2011 e um crescimento de $835 \%$ dos ativos totais ( $1 \%$ do total de 2011 ) e de $17 \%$ de agências controladas ( $2 \%$ do total de 2011). Por fim, destacavam-se os bancos sediados em Belo Horizonte mesmo com um aumento de $1.033 \%$ dos ativos controlados e de $6 \%$ do total de agências, situando-se com $0,6 \%$ e $1 \%$ do total de 2011.

Essas situações descritas revelam, portanto, hierarquias, fruto de competições entre os bancos situados nesses centros de gestão do território brasileiro ao longo desses anos; também revelam a permanência da dominância daqueles situados em São Paulo, Brasília e Osasco. 
Mas, ainda assim, essas situações são insuficientes para explicar grande parte das dinâmicas do sistema bancário nos anos 2000. Torna-se preciso, nesse sentido, situá-las em um contexto mais amplo de expansão, de oferta e de organização dos serviços financeiros, das quais fizeram parte uma combinação de condições para ação dos bancos no território: condições político-normativas, condições técnicas e condições urbano-regionais - Quadro 9.

\section{Quadro 9 - Anos 2000: Condições para a ação dos bancos na formação socioespacial brasileira}

\begin{tabular}{cl}
\hline Condições Político- & Autorização para funcionamento de Correspondentes \\
Normativas & bancários e expansão de fixos \\
& Novo Sistema de Pagamentos \\
& Bancarização \\
\hline Condições Técnicas & Maior Capacidade de Processamento da banda larga \\
& Consumo e difusão de smartphones e tablets \\
\hline Regionais & Hierarquização dos centros de gestão bancários no território \\
& Acessibilidade às redes de telecomunicações \\
& Concentrações econômicas e populacionais no território \\
(com aumento da renda da população mais pobre) & Dinâmica das atividades econômicas \\
& Estratégias próprias a cada banco para capilarização de \\
& serviços financeiros
\end{tabular}

Fonte: Elaboração própria.

Nesse período, a combinação entre regulamentações estatais e estratégias de ação dos bancos no território são elementos que nos ajudam a realizar uma primeira aproximação, do ponto de vista das condições político-normativas que permitiram uma reorganização da realização de operações e oferta de serviços financeiros na formação socioespacial brasileira.

O ano 2000 foi um momento importante para essa atuação dos bancos e para as respectivas estratégias e demandas de automação bancária. Com as resoluções $n^{\circ} 2.640$ (1999) e $n^{\circ} 2707$ (2000) do Banco Central um novo fixo passou a ser incorporado pelo sistema bancário: os chamados correspondentes bancários. Tratou-se, a bem da verdade, da possibilidade de oferta de serviços bancários "dentro" de estabelecimentos comerciais pré-existentes no território (farmácias, 
padarias, supermercados, lotéricas, agências de correios etc.) que, com esta nova regulamentação, passam a ser instalados nestes estabelecimentos (CONTEL, 2006; JAYO, 2010).

A difusão de correspondentes bancários tornou-se, nesse sentido, uma das principais soluções encontradas pelo sistema bancário nacional para sua expansão e permitiram com que muitos municípios pudessem, rapidamente, ter acesso aos produtos e serviços financeiros, devido à sua maior flexibilidade locacional, economia de capitais fixos e variáveis e sua funcionalidade (CONTEL, 2006). A interligação entre cada banco e "pontos conveniados", conforme foi observado por A. Moreira (2011), se deu por uma multiplicidade de arranjos tecnológicos e de possibilidades de conexão entre os atores.

A principal tecnologia utilizada nos correspondentes foram as máquinas conhecidas como point of sales, mas também houve totens, ATMs e computadores. Estes fixos operaram "como terminais nos pontos de serviços conveniados, e interligados aos sistemas transacionais de um banco contratante" (JAYO, 2010, p. 1). A conexão e a transmissão de dados transacionais entre esses atores fizeram-se através de envio de mensagens TCP/IP por meio de uma multiplicidade de canais, tais como internet, rádio (GPRS) e sistemas de telefonia 3G (MOREIRA, 2011).

Outro marco fundamental para essa ação dos bancos no território foi a instituição do novo Sistema de Pagamentos Brasileiro (SPB), consolidado também pelo Banco Central em conjunto com as instituições financeiras no ano de 2002, que permitiu uma maior integração entre sistemas de compensação e de liquidação. Para tanto, como ressaltou F. B. Contel (2011, p. 200), foi criado um conjunto de normas para regular as "transações diárias executadas pelos principais agentes financeiros instalados no território".

A bancarização da população foi, igualmente, um importante ponto convergente entre instituições do governo e sistema bancário. A aprovação das resoluções $n^{\circ} 3104$ e 3.113 pelo Banco Central, ambas no ano de 2003, foram decisivas na desburocratização da abertura de contas, permitindo uma expansão de contas-correntes e contas-poupanças, na ordem de 10 milhões entre 2003 e 2009, fazendo com que estivessem ainda abertas, nesse último ano, 5,5 milhões de contascorrentes simplificadas em 2009 (BACEN, 2010). O número total de contas 
correntes passou, dessa forma, de 63,7 milhões em 2000 para 125 milhões em 2008 (um aumento de 97\%), das quais 82 milhões foram movimentadas dentro de um período de seis meses desse último ano.

Esse processo de mudanças normativas, de autorização para funcionamento e abertura de novos fixos, somados ao crescimento dos ativos dos maiores bancos no país e às políticas sociais, das quais as de transferências de renda foram as mais destacadas, são fatores decisivos que também ajudam a entender o aumento de 26 milhões pessoas bancarizadas entre 2002 e 2011 (Gráfico 7).

\section{Gráfico 7 - Evolução da população bancarizada no Brasil (em milhões de pessoas)}

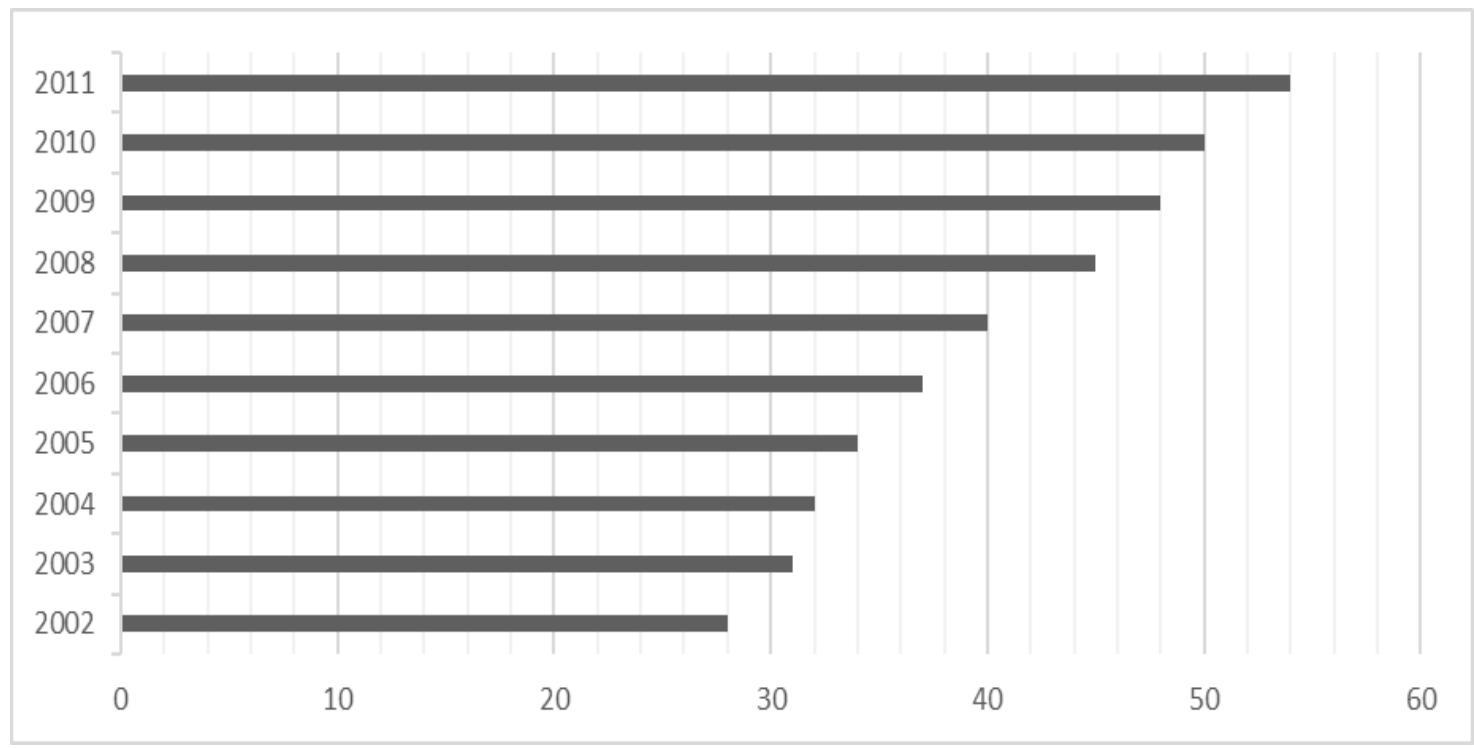

Fonte: Elaboração do autor com base em dados disponibilizados pelo Banco Central do Brasil.

A esses elementos podem ser acrescentadas as mudanças das condições técnicas para a ação dos bancos no território. Conforme destacou F. Contel (2011), a presença e expansão das redes-suporte informacionais, como foi o caso da continuidade na implantação das redes de fibra ópticas, além do consumo de objetos portadores de técnicas "banais" e "banalizadas" (telefones fixos, celulares, computadores pessoais) e do uso de redes com técnicas sofisticadas (as chamadas redes corporativas, como a Transdata, a Renpac e a SWIFT), são, conjuntamente, elementos estruturantes do sistema técnico atual que também influenciaram os processos de concentração das atividades econômicas no território, a interligação entre os lugares da formação socioespacial brasileira e deles e o mundo. 
O novo Sistema de Pagamentos Brasileiro (SPB), além das normas criadas, exigiu novos fixos e sistemas técnicos (modernizações do Sistema de Liquidação e Custódia - SELIC -, das câmaras de compensação de títulos e cheques, câmara interbancária de pagamentos, entre outros) com conteúdos capazes de garantir, ao menos: a) o armazenamento e a consolidação dos resultados operacionais das instituições financeiras existentes no país, de modo a garantir a atualização das posições credoras e devedoras no mesmo dia; b) o recebimento e o processamento de dados para a realização das transações intra e interbancárias, de forma instantânea (CONTEL, 2011).

O aumento da bancarização, a difusão de novos fixos bancários, a centralização e concentração dos centros de gestão do território e a expansão da oferta de serviços financeiros demandaram dos bancos maiores volumes de transações e de operações informacionais.

É nesse conjunto de transformações que se situaram as recentes reorganizações realizadas pelos maiores bancos em seus atuais Data Centers (DC). Entre 2005 e 2008, o Bradesco modernizou o seu Data Center em Osasco e criou um outro, de contingência, em Barueri. As demandas de segurança, confiabilidade, disponibilidade e velocidade de processamento de serviços financeiros, levaram o banco a investir um total de R\$ 22 bilhões nesse projeto, possuindo, em 2015, 300 servidores em operação, com capacidade de armazenamento de 12 peta bytes e com capacidade de processamento de 250.000 milhões de instruções por segundo. Um exemplo claro de como isso impactou nas velocidades para processamento de operações pode ser sistematizado da seguinte maneira: passou-se de um tempo de 16 minutos para 9 segundos para realizar a análise computacional da concessão de crédito automático; houve redução de $25 \%$ do tempo de atendimento nos caixas. No caso do saque em ATMs, essas novas capacidades de processamento, junto da adoção de biometria, permitiram uma redução do tempo necessário para realização da operação de 40 segundos para 25 segundos $^{40}$.

Já o Banco do Brasil iniciou a modernização do seu Data Center em 2010 e, em conjunto com a Caixa Econômica Federal, finalizou a criação de outro fixo

\footnotetext{
${ }^{40}$ Informações veiculadas pelo jornal Estadão Conteúdo de 28/01/2013 e reproduzida pela revista Época Negócios. Disponível em: http://epocanegocios.globo.com/Informacao/Acao/noticia/2012/10/bradescose-prepara-para-o-novo-momento-do-setor.html.
} 
geográfico deste tipo em 2013. Somando o total de recursos investidos, houve investimentos na ordem de $\mathrm{R} \$ 2,5$ bilhões e conjuntamente esses fixos estão dimensionados para processar 280.000 milhões de instruções por segundo e armazenar 10.000 Terá Bytes em dados. Segundo a expectativa é que esses novos fixos possam processar e armazenar as informações dos bancos pelos próximos $15 \mathrm{a}$ 20 anos, além de garantir o processamento das 60 milhões de transações realizadas por dia pelos clientes desse banco público. A Caixa Econômica Federal, além desse fixo compartilhado com o Banco do Brasil, investiu em um novo Data Center, construído em Brasília, no qual investiu um total de $\mathrm{R} \$ 160$ milhões e que a levou a desativar os seus antigos do Rio de Janeiro, São Paulo e Brasília ${ }^{41}$.

Outros dois grandes bancos que investiram em mudanças semelhantes foram o Santander e o Itaú. O primeiro construiu o seu Data Center em Campinas, inaugurado em uma área de $800.000 \mathrm{~m}^{2}$, no qual aportou aproximadamente $\mathrm{R} \$ 1$ bilhão; a escolha locacional, segundo Mirian da Silva Ferreira Guimarães (que é superintendente de TI da Produban, ligada ao grupo Santander), ocorreu pelo seguinte motivo:

Escolhemos Campinas porque está perto do escritório do Santander, em São Paulo, e há grande disponibilidade de energia e comunicação lá, além de acesso a vias terrestres e proximidade com o Ciatec II, onde temos $15 \%$ de nossas pesquisas ${ }^{42}$.

Atualmente esse Data Center está conectado aos outros três que o Santander possui no mundo, situados na Espanha, México e Inglaterra; o equipamento pode suportar suas atividades em outros países da América Latina e representou um aumento de $50 \%$ na sua capacidade de processamento de dados no Brasil. Ele é composto por 7 mil servidores, processa de 80.000 milhões de instruções por segundo capacidade de armazenamento de cinco peta bytes e pode efetuar 210 milhões de transações por dia (OLIVEIRA, 2015). Conforme ressaltou D. Oliveira (2015):

Para se ter uma ideia da sua grandiosidade, o data center tem 6 mil toneladas de aço, o equivalente ao Estádio do Morumbi, em São Paulo, 50 mil metros quadrados de concreto [o Arena Corinthians, também em São Paulo, tem 70 mil metros

\footnotetext{
41 Informações disponibilizadas pelo Sindicato dos Bancários do Rio de Janeiro, em 27/06/2014. Disponível em: http://www.bancariosrio.org.br/2013/ultimas-noticias/item/27656-bancos-investembilhoes-em-novos-centros-de-processamento-de-dados.

${ }^{42}$ A declaração foi dada à jornalista D. Oliveira e veiculada no jornal especializado IT FORUM 365, em 17/06/2016. Disponível em: http://itforum365.com.br/noticias/detalhe/116070/saiba-como-sao-os-datacenters-dos-maiores-bancos-instalados-no-brasil.
} 
quadrados de concreto], além de $275 \mathrm{Km}$ de canalizações enterradas e uma subestação de energia com potência de $50 \mathrm{mil} \mathrm{KW} / \mathrm{h}$ - suficiente para abastecer uma cidade como Ilha Bela, no litoral paulista.

O Itaú, por sua vez, investiu $\mathrm{R} \$ 3,3$ bilhões na construção de um novo Data Center, com $815.000 \mathrm{~m}^{2}$ e localizou-o em Mogi-Mirim. Esse fixo foi inaugurado em março de 2015 e esperava-se que, nesse mesmo ano, fossem processadas 35 bilhões de transações e espera-se que suporte as operações do banco até o ano de 2050. Nesse local foram construídos dois Data Centers, interligados, totalizando 9,7 mil servidores, 26 petas bytes de armazenamento e uma capacidade de processamento de 235.000 milhões de instruções por segundo.

Esses novos Data Centers, ligados funcionalmente às sedes dos bancos, representam, nesse sentido, novas qualidades dos centros de gestão bancária no território brasileiro, permitindo-os exercer o controle, o acompanhamento em tempo real e uma expansão ainda maior de suas atividades na formação socioespacial brasileira. É justamente por essas necessidades, que os atuais DC são pensados a partir de uma metáfora militar, como os bunkers do século XXI, cuja principal preocupação, para além da segurança física e das necessidades de espaço, é a garantia de uma informação estratégica protegida e centralizada em servidores com capacidade de armazenamento e de processamento elevadíssimas, que permitem a sua circulação a velocidades cada vez maiores nas redes técnicas do território, ao mesmo tempo em que é "encapsulada" por criptografias e por uma constante atualização de procedimentos e softwares de segurança.

Essas são as principais razões para a localização desses fixos próximos às sedes dos bancos, em locais onde a garantia de espaço e de vigilância se somam à acessibilidade e às disponibilidades de densas redes de telecomunicações.

Deve-se ressaltar ainda que esses processos, somados aos de bancarização e expansão dos fixos e serviços, contribuíram para o aumento exponencial das transações bancárias, que passaram de aproximadamente 13.866 milhões em 2008 para 28.888 milhões em 2015; os valores transferidos, que eram $\mathrm{R} \$ 7.238$ bilhões em 2008, foram R\$ 16.858 bilhões em 2015.

Segundo dados da Federação Brasileira de Bancos (FEBRABAN) e do Banco Central do Brasil, entre 2002 e 2011 houve um aumento de 128 mil correspondentes no país, ao mesmo tempo em que o número de cartões magnéticos 
cresceu de 183 para 687 milhões. Ambos são fatores importantes para a utilização das máquinas conhecidas como points of sales, popularmente conhecidas como "maquininhas de cartão" e utilizadas pela população principalmente no comércio.

Os novos conteúdos técnicos das redes de telecomunicações, com a banda larga, as políticas de expansão da internet no território e o aumento do consumo na formação socioespacial brasileira são elementos importantes que ajudam a explicar o aumento do número de contas correntes com internet banking em 33 milhões entre 2002 e 2011, atingindo a marca de 49 milhões de contas com esse acesso em 2011. E também do chamado mobile banking, isto é, das contas acessadas vias celulares smartphones que passaram de zero em 2008 para 3,3 milhões em 2011 (FEBRABAN, 2012a).

Esses dados nos ajudam a caracterizar e dimensionar essas necessidades atuais de investimentos para armazenamento, processamento e transmissão de dados entre os fixos bancários e situar os aumentos de investimentos bancários em tecnologias da informação e comunicação. Tais investimentos passaram de 12 bilhões de reais em 2008 para a marca de 20 bilhões em 2012 (FEBRABAN, 2012b).

\section{O consumo e os usos dos ATMs na formação socioespacial brasileira}

Nesse movimento de expansão de fixos e canais de atendimento e de serviços bancários, em conjunto com a crescente bancarização da população e dos novos conteúdos técnicos, houve novas demandas para o uso de ATMs. Como pode ser visto no Quadro 10, há novos terminais sendo produzidos e comercializados, como os terminais recicladores, que podem reutilizar notas de depósitos em transações para saque de dinheiro.

Conhecidos como caixas recicladores, esses novos objetos técnicos possibilitam, segundo A. Bronzati (2014), "mais dinheiro efetivo" e reduzir "gastos com transportes de valores". Já C. Bouças (2014) enfatizou o fato de tal caixa possuir "tecnologia capaz de reconhecer cédulas e identificar notas verdadeiras e falsas" permitindo que o "dinheiro de depósitos seja reaproveitado para saque, reduzindo os custos de transporte de valores entre $40 \%$ e $50 \%$, segundo os fabricantes". Esse terminal já estava presente em 46 países do mundo, enquanto 
que, no Brasil, apenas a empresa Saque e Pague possuía este tipo de caixa em operação, comprados da empresa Diebold. As fabricantes OKI Brasil, NCR e Perto Tecnologia estavam em negociação com bancos e clientes para instalação desses terminais (BOUÇAS, 2014).

\section{Quadro 10 - Tipologia das novas demandas para produção e consumo de ATMs}

\begin{tabular}{cl}
\hline Tipo de ATM & \multicolumn{1}{c}{ Características Principais } \\
\hline ATMs Recicladores de Notas & $\begin{array}{l}\text { Identificação de cédulas e armazenamento de notas } \\
\text { depositadas para saques. }\end{array}$ \\
\hline $\begin{array}{c}\text { ATMs com identificação } \\
\text { biométrica }\end{array}$ & $\begin{array}{l}\text { Identificação biométrica de indivíduos (íris, veias das } \\
\text { mãos e digitais), para realização de transações. }\end{array}$ \\
\hline $\begin{array}{c}\text { ATMs fabricados com designs } \\
\text { e com materiais de modo a } \\
\text { torná-los mais seguros }\end{array}$ & $\begin{array}{l}\text { Mudanças de configuração física do equipamento de } \\
\text { modosonos torná-los resistentes às tentativas de furtos e }\end{array}$ \\
\hline
\end{tabular}

ATMs com tecnologia NFC Permite a realização de operações iniciadas em dispositivo ("Near Field Communication") móvel - smartphone e/ou tablet, por exemplo.

\begin{tabular}{cl}
\hline ATMs Multimoedas & Realização de operações de câmbio de pequeno valor \\
\hline ATMs compartilhados & $\begin{array}{l}\text { Permite que clientes possam usar a rede de qualquer } \\
\text { banco para realização de transações }\end{array}$ \\
\hline
\end{tabular}

ATMs para automação comercial
Uso de ATMs para consultas, compras de itens ou para serviços financeiros de lojas varejistas (abertura de crediário, por exemplo) ou serviços diversos (realização de check-in em aeroportos, por exemplo)

Fonte: Elaboração Própria.

Outra demanda para os terminais produzidos para o mercado brasileiro, segundo a revista ComputerWorld (2015), é a incorporação de biometria, que tem ganhado destaque na área tecnológica nos últimos anos. Espera-se que entre os anos 2015 e 2024 acumule, no mundo inteiro, um total de investimentos no valor de US\$ 67,8 bilhões. Além disso, a revista destaca os seguintes elementos: "A expectativa é que ela seja empregada em transações em pontos de venda, acesso a áreas restritas de distribuição de medicamentos, ambientes virtuais de sistemas governamentais, entre outros" (COMPUTERWOROLD, 2015). O Brasil é visto como um país estratégico dentro da América Latina para a realização de investimentos, dada a complexidade e sofisticação das suas tecnologias no sistema financeiro (COMPUTERWORLD, 2015). 
A esse respeito, o relatório de Tecnologia Bancária da FEBRABAN de 2014 ressaltou que 60\% dos ATMs no Brasil estavam equipados com biometria, apresentando crescimento de $28 \%$ em relação a 2013.

Foi destacado que no ano de 2014 houve uma coleta de 45 milhões de amostras biométricas pelos bancos - aumento de $70 \%$ em relação ao ano anterior. Assim, o relatório apontou para a seguinte conclusão:

A tendência de crescimento exponencial das coletas biométricas - que cresce em ritmo mais acelerado do que o de ATMs equipados com essa tecnologia -, acompanhada do aumento significativo dos ATMs com função de biometria, configura um cenário cada vez mais favorável à exigência da padronização da segurança para facilitar ainda mais a experiência do cliente (FEBRABAN, 2014, p16).

Nesse contexto, destacam-se as iniciativas de diversas empresas e bancos. Uma delas é a empresa japonesa Fujitsu, que desde 2006 comercializa no Brasil equipamento capaz de identificar indivíduos a partir das veias de suas mãos. $\mathrm{O}$ Bradesco foi então seu primeiro cliente e as fabricantes Diebold e Perto estabeleceram parcerias para equipar seus ATMs com esse tipo de tecnologia. Outra fabricante desse equipamento é a Itautec (atual OKI Brasil) que, em 2010, investiu um total R $\$ 70$ milhões em pesquisa e desenvolvimento e conseguiu criar tecnologia 3D, para evitar que o cliente tenha contato direto com o cofre do equipamento; tecnologia de reconhecimento da face do cliente, que pode cancelar a operação caso apareça uma nova pessoa em frente a tela. (SILVA JUNIOR, 2010). Por fim, destaca-se também o Banco do Brasil, que, por meio da empresa Cobra, tem investido no terminal Bio 001, que pode autenticar transações por íris e voz. Além disso, poderá realizar "seleção por olhar", identificando a retina como se fosse um mouse.

Em função do crescente número de roubos a ATMs, as empresas têm investido também em novos designs e materiais. Em 2012, a Diebold e a TecBan desenvolveram um terminal resistente à dinamite, em um projeto que custou $R \$ 1$ milhão de reais (SILVA JUNIOR, 2012). Em 2013, a Itautec começou a produzir um ATM com duas telas para atendimento e apenas um cofre. Segundo C. Bouças (2013), "O cofre de um caixa eletrônico tradicional fica abaixo da tela de atendimento. O novo equipamento, no entanto, permite colocar o cofre em uma 
posição diferente da tela e com um recuo de até 30 centímetros em relação ao caixa".

Nos últimos anos, a internet e o celular superaram os ATMs em volume de transações bancárias realizadas por clientes. Diante dessa situação, os fabricantes desses últimos passaram a investir em novas tecnologias denominadas $N F C$ (Near Field Communication); como destacou C. Bouças (2013), "fabricantes como Itautec, Perto e NCR trazem ao mercado (...) ATMs com funções que se integram à internet móvel, ou apresentam novas funções para que o cliente do banco possa realizar mais operações ao usar um caixa eletrônico".

Assim, em 2013 a Itautec foi a primeira empresa instalada no Brasil a desenvolver a tecnologia NFC. Por meio dela, tornou-se possível "iniciar uma operação de saque no seu dispositivo móvel - smartphone, tablet ou outro - e apenas fazer a retirada do dinheiro no terminal. Para concluir a operação, o cliente do banco precisa apenas aproximar o celular do ATM" (BOUÇAS, 2013).

Em 2012, com autorização concedida pelo Conselho Monetário Nacional (CMN), os ATMs puderam ser utilizados inclusive para operações de câmbio de pequeno valor. Segundo M. Drska (2012a), foi estabelecido limite de US\$ 3 mil para cada transação e a obrigatoriedade da "sustentação de um banco ou uma agência de câmbio". As operações seriam identificadas e realizadas "por meio de cartão de crédito com bandeira internacional ou através de passaporte com validação eletrônica de autenticidade".

Esse uso dos terminais já era autorizado na Europa e Estados Unidos, tanto em máquinas destinadas somente a este tipo de operação (conhecidas como "cambiadoras"), quanto em máquinas "não especializadas", como um módulo adicional. Contudo, como ressaltou M. Drska (2012a), as empresas existentes no Brasil já haviam se antecipado à resolução e desenvolvido seus próprios terminais. Como exemplo, pode-se destacar: a empresa brasileira Perto, que, de 2008 a 2012, desenvolveu projetos para produzir esse tipo de ATMs, com investimento de R $\$ 4,8$ milhões de reais e envolvimento de 80 profissionais (engenheiros, analistas de sistemas e equipe de suporte); a Itautec, que possuía dois mil equipamentos instalados nos Estados Unidos e México e passou a trabalhar em conjunto com um banco nacional e outro internacional para desenvolver o projeto e produzi-lo em 
sua fábrica em Jundiaí; a empresa alemã, Hess, que, por meio de sua filial Hess Latam, instalou-se no Brasil em 2011. Com investimento previsto de 2011 a 2016 no valor $\mathrm{R} \$ 50$ milhões, tem buscado estruturar suas operações e produzir as "cambiadoras" no país (DRSKA, 2012a).

Além desses exemplos, M. Drska (2012a) relata algumas das possíveis dificuldades acerca da produção, comercialização e uso desse tipo de equipamento:

$\checkmark$ Necessidades dos fabricantes "provarem" que o equipamento "pode deixar de ter uma aplicação segmentada, voltada apenas a aplicações relacionadas a grandes eventos ou ao atendimento de turistas";

$\checkmark$ Preço desse tipo de ATM: enquanto os terminais convencionais custam de R\$ 30 mil a 35 mil (no Brasil), uma unidade com esse tipo de função custaria entre R $\$ 50$ mil e R \$ 60 mil;

$\checkmark$ Diferença de valores entre as moedas aumenta complexidade do terminal. Isso significa "um tratamento distinto de um ATM convencional, especialmente em campos como armazenamento, reconhecimento de valores, sistemas de conversão de câmbio e dispensa de moedas (...). Entre os equipamentos adicionais estão um scanner usado para reconhecer a autenticidade das cédulas."

O projeto de compartilhamento de ATMs começou em 2003, por intermédio do presidente da Federação Brasileira de Bancos à época, Marcio Cypriano. Os primeiros bancos a adotarem o compartilhamento de seus respectivos terminais foram Banco do Brasil e Caixa Econômica Federal, em 2004. Embora com terminais próprios, os ATMs da Tecban e da Rede Verde e Amarela (ligada aos bancos estaduais remanescentes) também eram compartilhados por diversos bancos (RODRIGUES, 2004).

Desde 2013 o Itaú, por meio de parceria com a empresa Rede, permite que não correntistas do banco realizem pagamentos de contas em seus ATMs. Segundo C. Mandl (2015): "Por mês, 80 mil pagamentos são feitos no ATM por nãocorrentistas. A expectativa é alcançar esse ano 500 mil". Em 2014 os bancos aceitaram compartilhar seus ATMs para função de saque, também. Segundo C. Mandl (2015), "Em dezembro, eram 16,7 mil caixas eletrônicos que podiam atender correntistas de Itaú, Bradesco, BB, Caixa, HSBC e Citi”. 
O Bradesco, em parceria com a Cielo, também passou a oferecer essa possibilidade de uso de seus terminais em 2015. Banco do Brasil, Caixa e Santander buscam também transformar "seus caixas eletrônicos em terminais aptos a aceitar os cartões de qualquer banco para pagamento de boletos e impostos" (MANDL, 2015).

Entre as motivações dos bancos encontram-se (MANDL, 2015):

$\checkmark$ Buscar aumentar a eficiência dos ATMs;

$\checkmark$ Redução do fluxo de clientes nas agências;

$\checkmark$ Busca pela "captação" de correntistas de outros bancos;

$\checkmark$ Oferecer uma opção mais cômoda para os usuários de serviços bancários;

$\checkmark$ Dividir serviços básicos tendo em vista a redução de despesas;

O relatório da FEBRABAN (2014), aponta ainda que o "modelo brasileiro", de "terminais proprietários", fez com que houvesse um grande número de equipamentos, ao mesmo tempo em que um volume menor de transações por terminal. Em outros países, o compartilhamento de serviços tem sido o "modelo" adotado, o que vem começando a ocorrer no país. O referido relatório resume essas questões em dois pontos:

1. "O movimento de consolidação dos ATMs e o compartilhamento de serviços pelos bancos estão muito relacionados a diretrizes de segurança e eficiência, sem perda de qualidade de serviço para o cliente bancário" (FEBRABAN, 2014, p. 14)

2. "Há que se considerar o fato de que o Brasil está caminhando rumo a esse destino e o movimento de consolidação do canal de ATMs deve ser visto mais intensamente nos próximos anos, melhorando a eficiência em métricas como, por exemplo, número de transações por ATM" (FEBRABAN, 2014, p. 18)

Por fim, há demanda de ATMs para automação comercial. Essa demanda tem origens na década de 1990, quando iniciou um movimento crescente de integração, nas empresas, entre automação bancária e comercial. Tal fato, já havia sido notado em estudo do Banco Nacional de Desenvolvimento (BNDES), elaborado por Melo et ali (2000). Segundo os autores, 
Os mercados de automação bancária e comercial até aqui têm sido distintos, assim como distinta tem sido a sua caracterização. Entretanto, existem relações cada vez mais intensas entre esses dois tipos de automação, como é o caso, por exemplo, da transferência automática de fundos realizada nos PDVs [pontos de venda] das lojas ou da colocação de ATMs no comércio. Estamos assistindo também à extensão do conceito de ATM, que, originário da automação bancária, vem gerando terminais de autoatendimento para compra de itens em lojas de correio, informações sobre controle de consultas médicas, saldos de cartões de crediário em cadeias de lojas etc. Além disso, boa parte dos fornecedores de soluções atua em ambas as áreas de automação, acrescentando ao seu portfólio de produtos serviços de assistência técnica, suporte operacional, supervisão e, até, operação. (MELO et ali, 2000, p. 52 e 53)

Outro ponto importante a ser considerado é a lei que obriga a emissão da Nota Fiscal Eletrônica, que implica na obrigatoriedade da automação comercial. A integração entre computador e impressora fiscal ocorre por meio de software produzido por diferentes empresas - inclusive aquelas ligadas à automação bancária -, como a Itautec, Bematech, Urmet Daruma, NCR. Porém, como ressaltou G. Brigatto (2012),

A venda desse tipo de sistema exige volume. Como o valor pago pelo pacote de produtos costuma ser baixo - um kit completo custa cerca de $\mathrm{R} \$ 5$ mil, com possibilidade de financiamento pelo cartão do Banco Nacional de Desenvolvimento Econômico e Social (BNDES) -, os fabricantes precisam de um alto volume de vendas para ter bons resultados.

Recentemente, C. Bouças e B. Cortez (2012) diagnosticaram a mesma "tendência", com a crescente expansão do uso dos Terminais de Autoatendimento no varejo. Tais terminais são produzidos pela NCR, Itautec, Motorola Solutions, entre outras que não foram citadas. No levantamento realizado, o objetivo do uso é a redução de filas e de custos operacionais. Nesses terminais, é possível efetuar compras em lojas de roupas, supermercados, companhias aéreas, cinemas. Para esses jornalistas especializados, com o crescente uso de ATMs no varejo, estaria em curso uma expansão da cultura do "autosserviço", muito embora também ressaltam que haveria ainda "consumidores receosos" em utilizar tais terminais (BOUÇAS \& CORTEZ, 2012).

Estas questões apontam para as atuais demandas para produção, distribuição e consumo dos ATMs em diversas atividades. No sistema bancário, especificamente, conforme o levantamento realizado pela FEBRABAN em 2014, atualmente $62 \%$ do total são considerados "ATMs full", isto é, possuem a máxima concentração de funções (pagamentos, dispensador de cédulas, depósitos/extratos e 
dispensador de cheques) que um equipamento desse tipo pode ter, o que indica uma possibilidade de expansão desse tipo de objeto técnico "mais complexo" em relação aos demais. Outro dado importante que ajuda a caracterizar a demanda e uso desses terminais, diz respeito à acessibilidade a pessoas com deficiência: $94 \%$ do "parque instalado" possui acessibilidade.

Ao longo dos anos 2000, como pode ser visto Gráfico 8, as principais operações realizadas nos ATMs foram consultas de saldo e numerário e saque. Os ATMs são o $2^{\circ}$ principal "canal" de transações bancárias ( $21 \%$ do total), superados apenas pela internet (39\%) - Gráfico 9.

\section{Gráfico 8 - Transações em Rede de Terminais ATM por Tipo de Acesso e Função (2006} 2014)

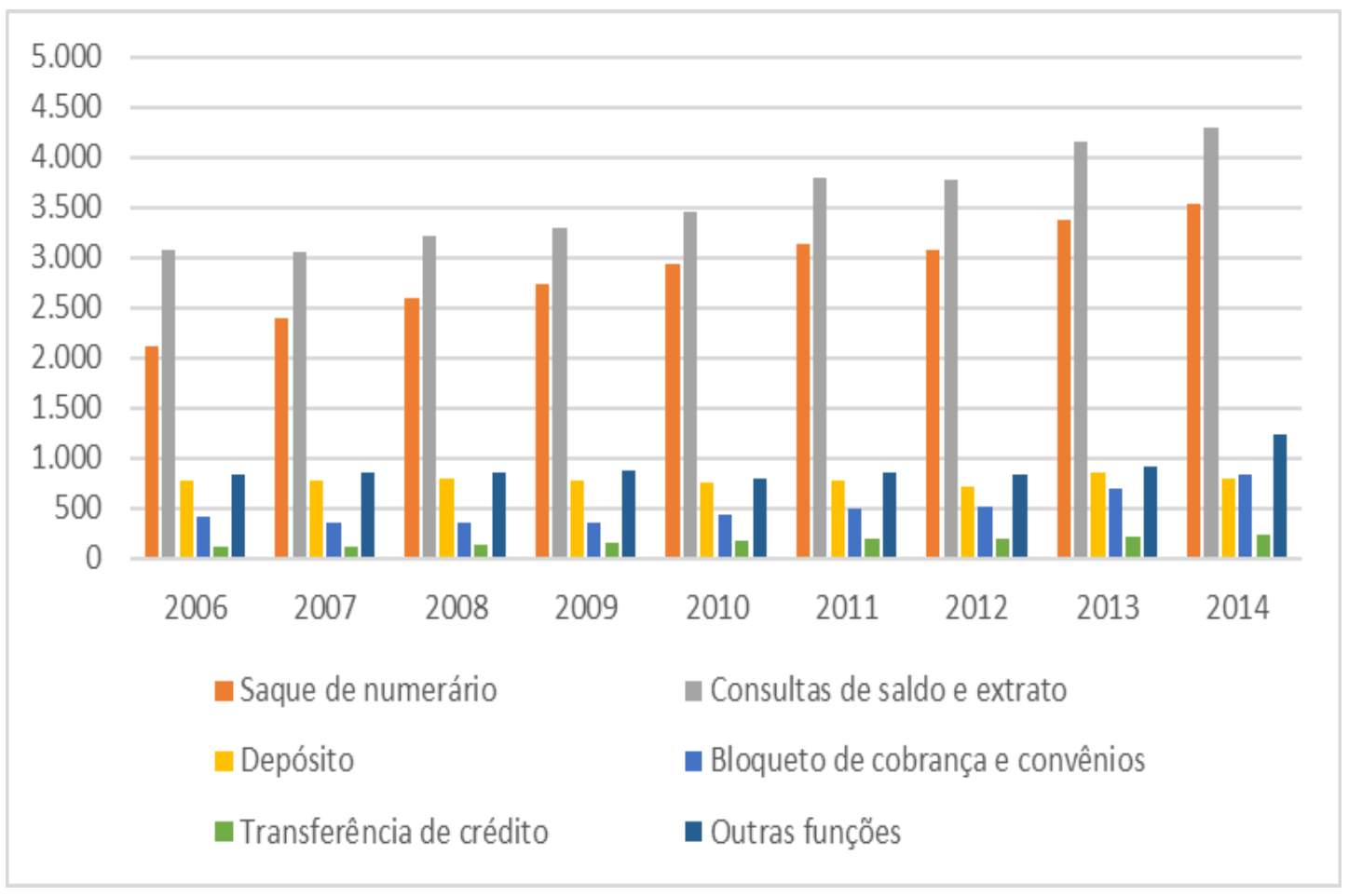

Fonte: Banco Central do Brasil, Adendo Estatístico do Diagnóstico do Sistema de Pagamentos de Varejo do Brasil - vários anos. 
Gráfico 9 - Quantidade (milhões) de Transações Bancárias por Canais de Acesso 2006 a 2014

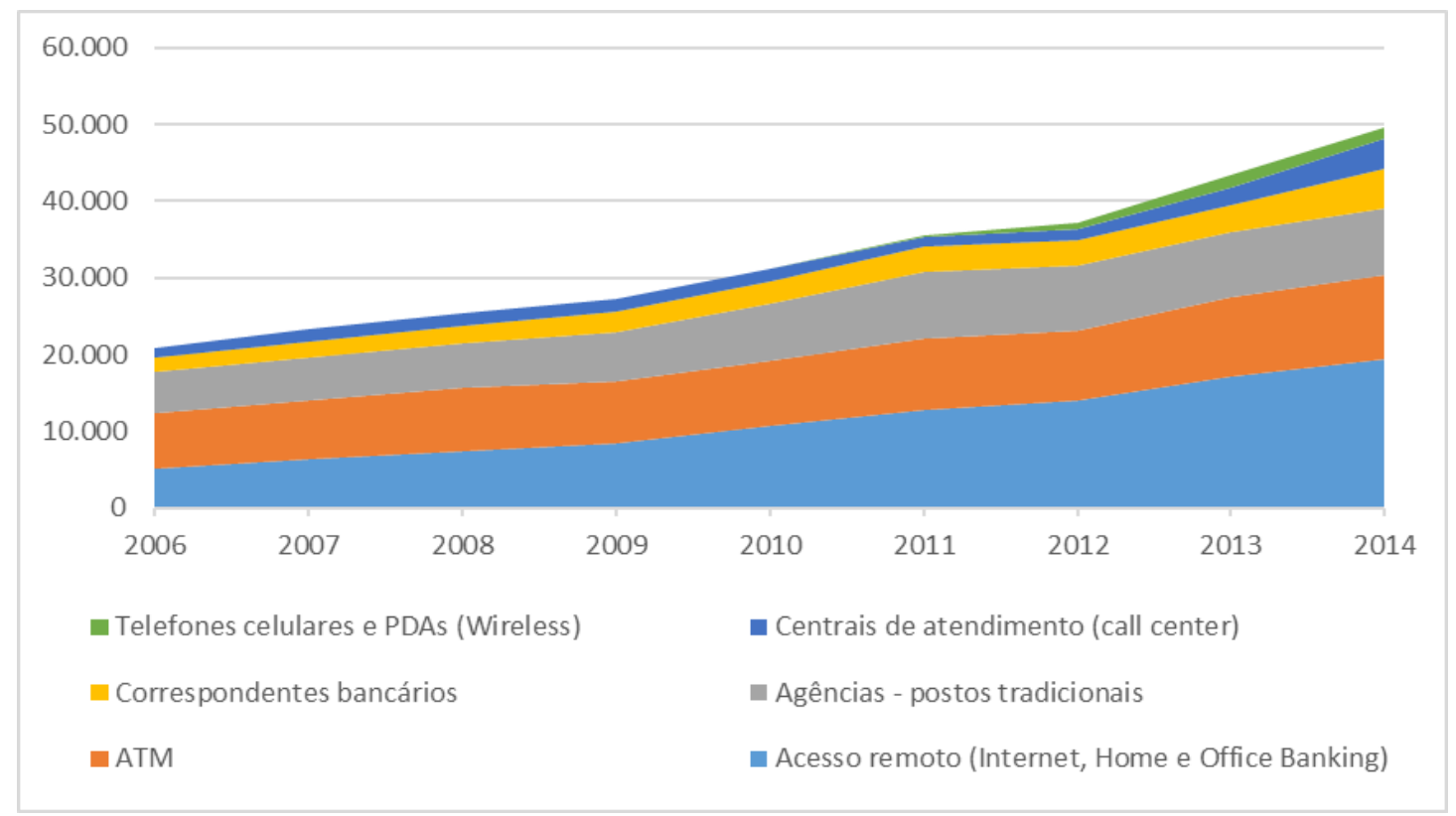

Fonte: Banco Central do Brasil, Adendo Estatístico do Diagnóstico do Sistema de Pagamentos de Varejo do Brasil - vários anos.

Gráfico 10 - Transações Bancárias por Canais de Acesso por Tipo de Operação em 2014

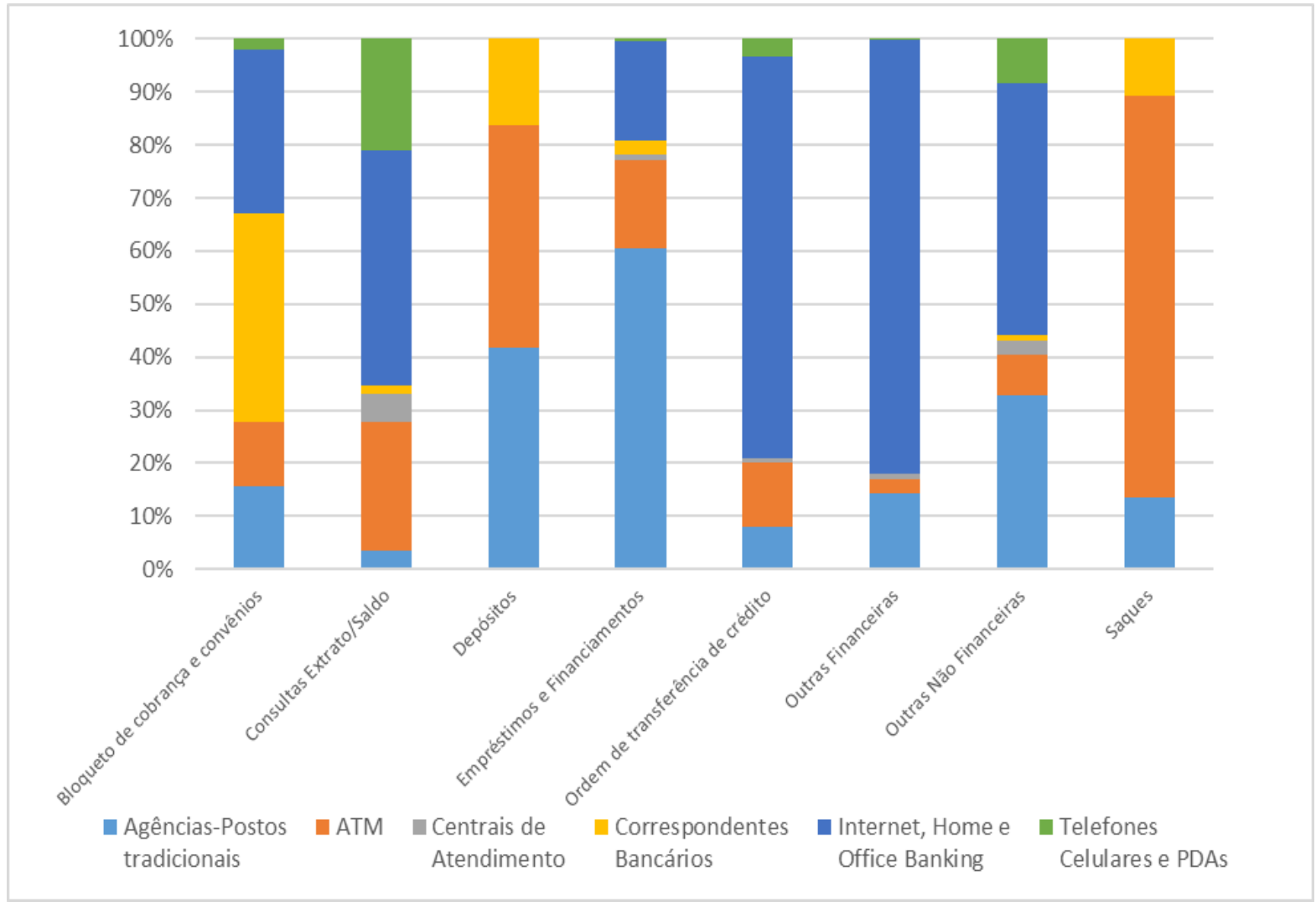

Fonte: Banco Central do Brasil, Adendo Estatístico do Diagnóstico do Sistema de Pagamentos de Varejo do Brasil - vários anos. 
Mesmo com a ascensão do internet banking e das transações por esse meio, nos últimos cinco anos (2010-2014) houve um crescimento médio de $6 \%$ no volume total de transações realizadas nesse equipamento, sendo, em 2014, o principal fixo bancário utilizado para realização de saques e um dos mais utilizados para a realização de depósitos (Gráfico 10). No Gráfico 11 é possível observar que as quantias totais são elevadíssimas; desde 2007, os saques ultrapassam os R $\$ 500$ bilhões de reais em transações e os depósitos alcançam valores significativos também.

\section{Gráfico 11 - Rede de Terminais ATM: valor das transações (R\$ bilhões) por tipo de função}

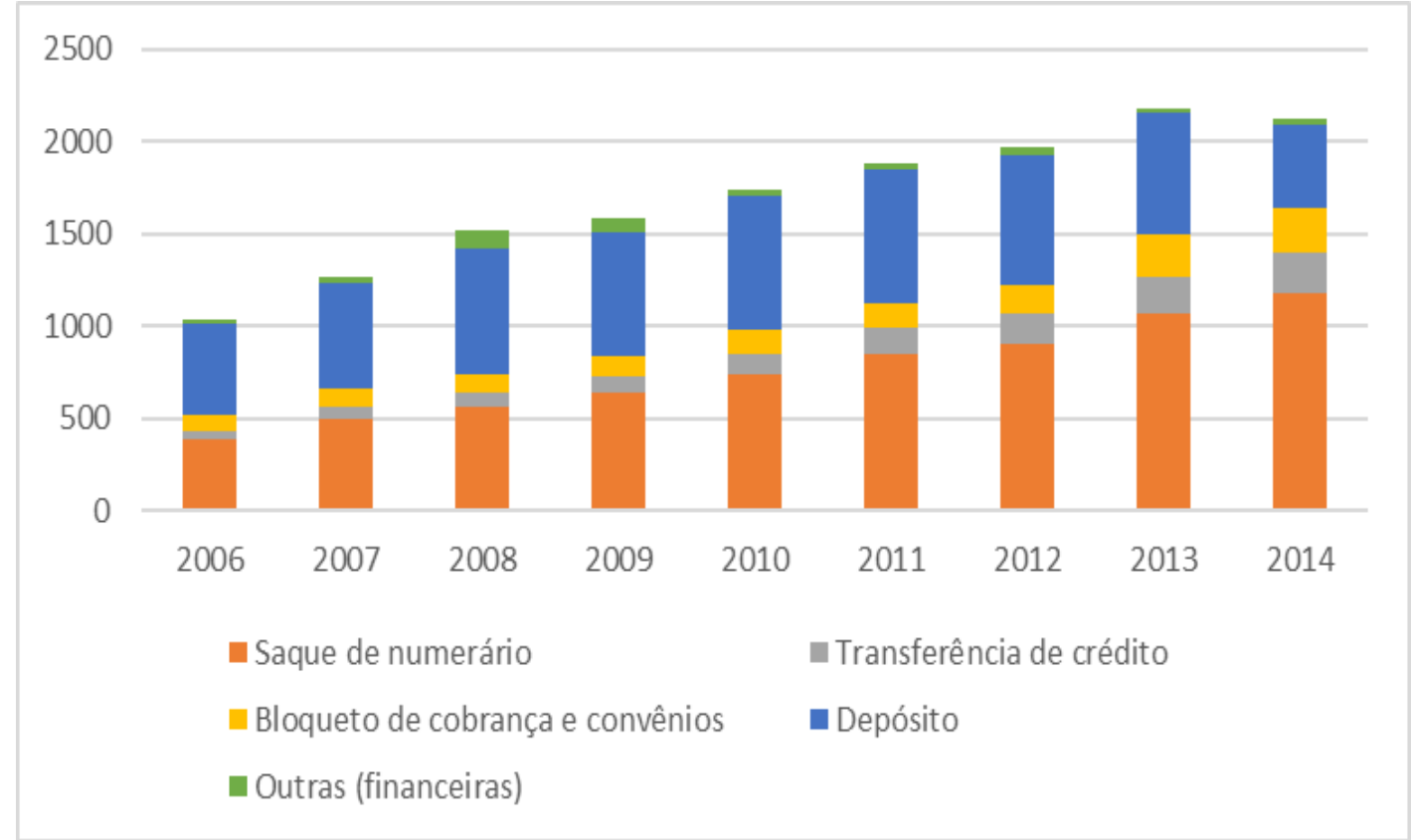

Fonte: Banco Central do Brasil, Adendo Estatístico do Diagnóstico do Sistema de Pagamentos de Varejo do Brasil - vários anos.

Assim, entre 1999 e 2015 houve um grande aumento do número de $\mathrm{ATMs}^{43}$ utilizados pelos bancos no território nacional. Como pode ser visto no Gráfico 12 , de 1999 a 2005 houve um maior ritmo de expansão, com incremento de 70\%; entre 2005 e 2010, o total desses terminais instalados cresceu a 19\%; por fim, o período entre 2010 e 2015, foi marcado por um ritmo médio de crescimento mais lento, da ordem de $4 \%$.

\footnotetext{
${ }^{43}$ Deve-se enfatizar que a presença dos ATMs no Brasil é significativa, cuja razão, em 2013, de 220 terminais por 100 mil habitantes constituiu-se como a maior do mundo, seguida por uma razão de 177 terminais nos Estados Unidos e de 128 terminais na Alemanha (FEBRABAN, 2013).
} 
Gráfico 12 - Crescimento da quantidade de ATMs no Brasil (1999-2015)

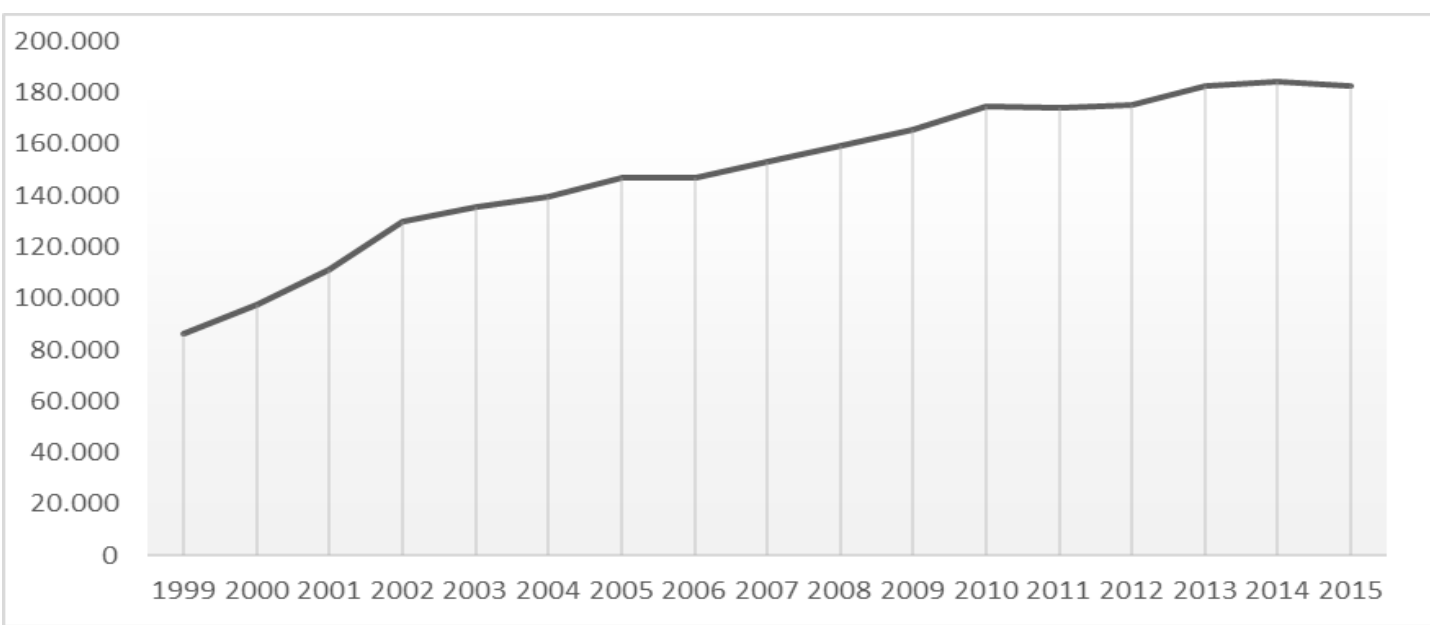

Fonte: Banco Central do Brasil, Adendo Estatístico do Diagnóstico do Sistema de Pagamentos de Varejo do Brasil - vários anos.

No entanto, essa expansão não se processou da mesma forma segundo os estados do país. Como pode ser visto no Gráfico 13, São Paulo, com 50.099 terminais instalados $(34,1 \%)$ possuía a maior quantidade; era seguido pelo Rio de Janeiro (com 11,2\% e um total de 16.419 equipamentos), Minas Gerais com 14.159 unidades (9,65\%), Rio Grande do Sul (9.833 unidades e 6,70\% do total), Paraná ( 8.881 unidades e $6,05 \%$ do total) e Bahia (com 6.510 unidades e $4,43 \%$ ).

Como pode ser visto no Gráfico 14, entre 2005 e 2015, o estado de São Paulo, com crescimento de $6 \%$, foi o que registrou o menor percentual, seguido pelo Distrito Federal (13\%), Espírito Santo (17\%), Rio de Janeiro (17\%) e Santa Catarina (18\%). Dez Estados apresentaram taxas elevadas, com incremento acima de 60\%: Amapá (86\%), Pará (86\%), Amazonas (75\%), Acre (72\%), Roraima (71\%), Rondônia (69\%), Maranhão (64\%), Mato Grosso (64\%), Ceará (62\%) e Piauí (60\%). É importante notar que, nesse período, com exceção do Estado de São Paulo, todos os demais Estados apresentaram taxas acima de 10\% de aumento, mas com forte expansão naqueles da Região Norte, Nordeste e Centro-Oeste. Esses dados apontam para uma possível estratégia inicial da expansão de ATMs até os anos 2000, direcionando-os para as Unidades da Federação com maiores concentrações populacionais e com uma dinâmica urbano-regional mais consolidada. Posteriormente, houve a expansão para as demais. 
Gráfico 13 - Quantidade de ATMs por Estado em 2005

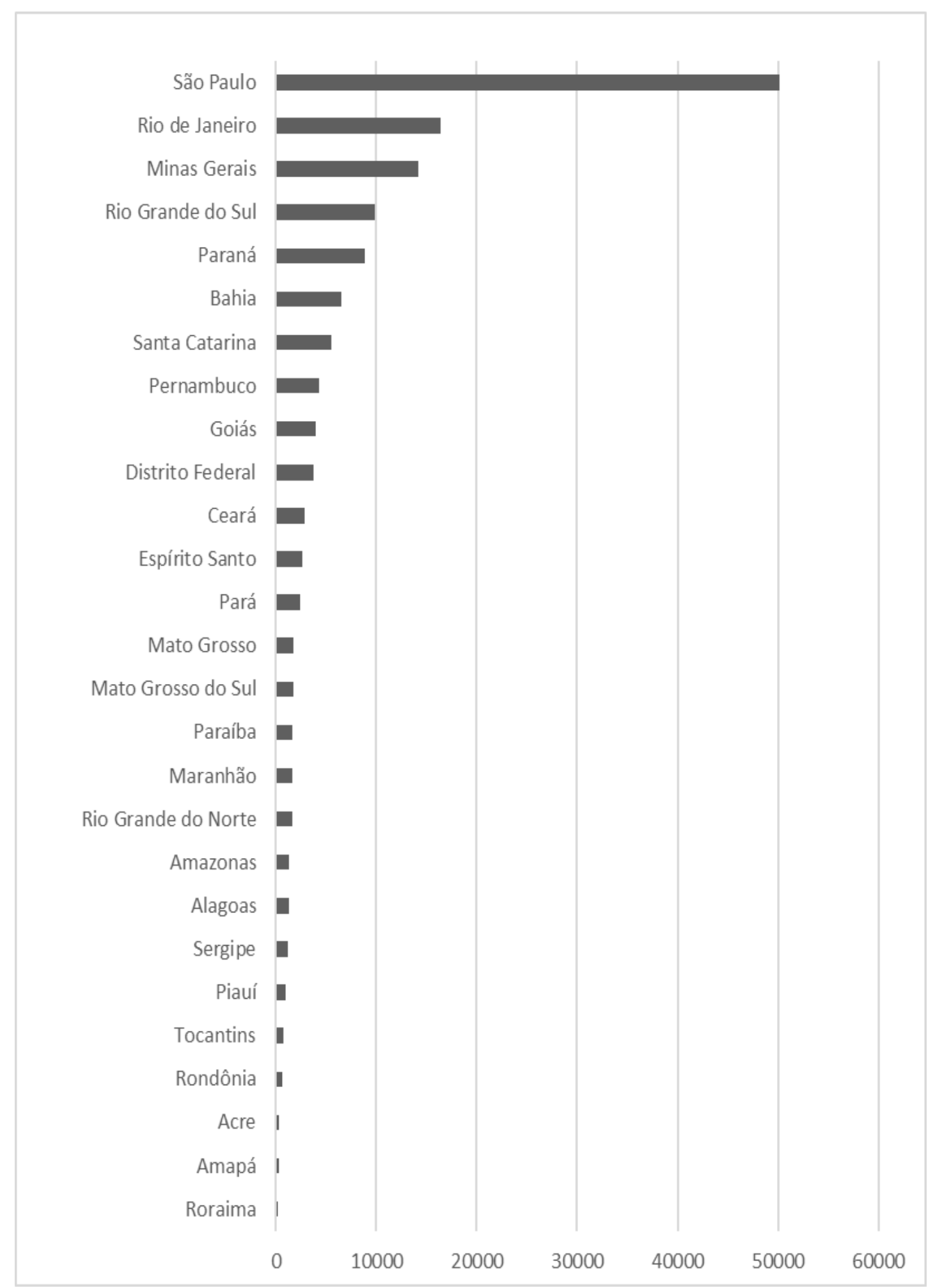

Fonte: Banco Central do Brasil, Adendo Estatístico do Diagnóstico do Sistema de Pagamentos de Varejo do Brasil - 2005. 
Gráfico 14 - Aumento do número de ATMs entre 2005 e 2015 (em \%)

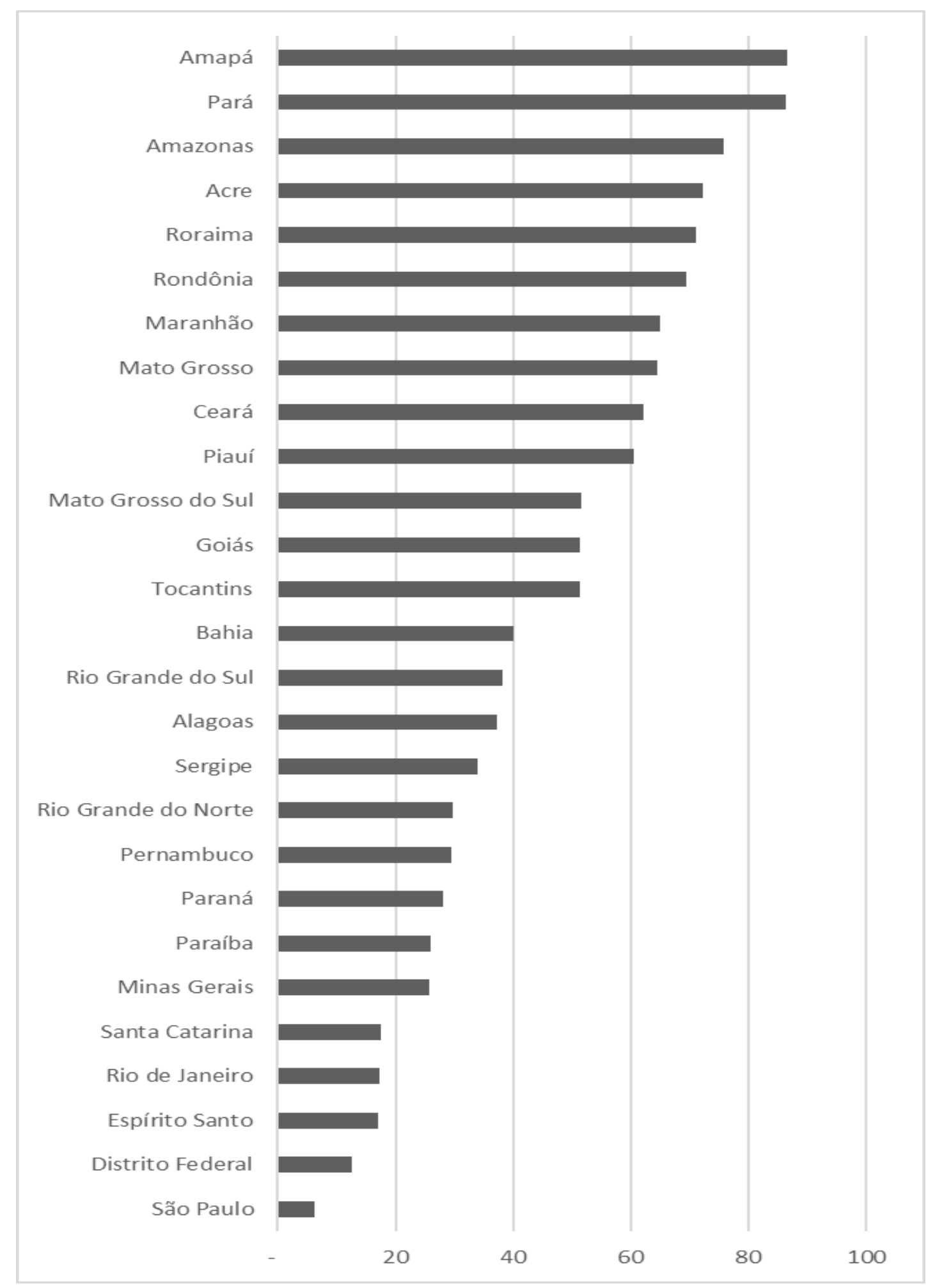

Fonte: Banco Central do Brasil, Adendo Estatístico do Diagnóstico do Sistema de Pagamentos de Varejo do Brasil - vários anos. 
Dessa maneira, ainda que o Estado de São Paulo tenha perdido participação, em 2014 concentrava 54.073 unidades, que significava $29,88 \%$ do total de ATMs existentes na formação socioespacial brasileira. O Rio de Janeiro possuía a segunda maior quantidade, com 20.036 , equivalentes a $11,07 \%$ do total; era seguido pelo Estado de Minas Gerais (17.689 unidades e 9,78\%), pelo Rio Grande do Sul (12.124 terminais e 6,81\%), Paraná (10.630 e 5,87\%) e Bahia (9.122 e 5,04\%). No Mapa 7 é possível observar a participação dos demais estados da federação.

Mapa 7 - Quantidade de ATMs por Unidade da Federação (2015)

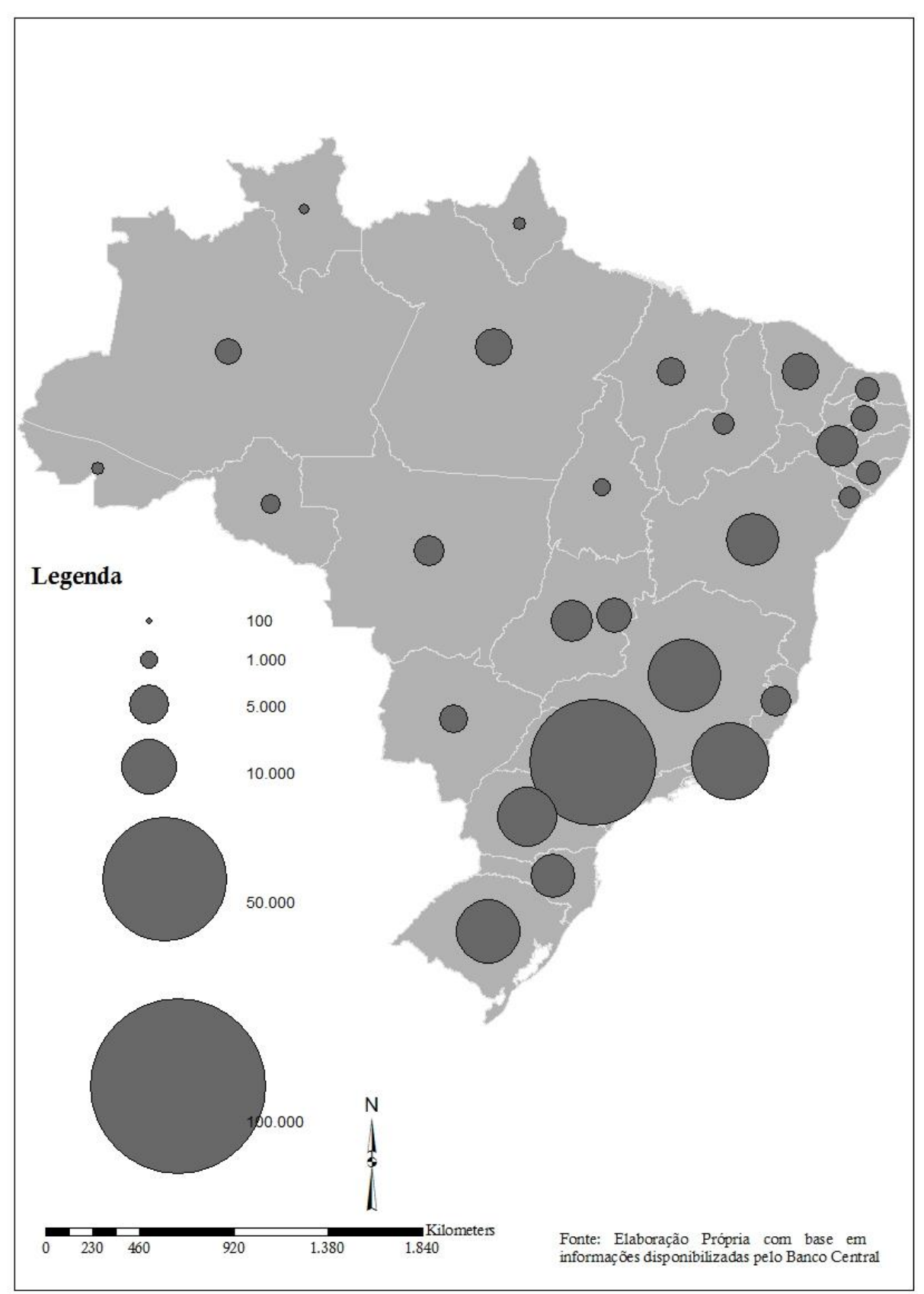


De forma a entender melhor a localização dos ATMs, foi utilizada a variável "Postos de Atendimento Eletrônico" (PAE) existentes no país em 2016. Essa variável, recolhida e disponibilizada pelo Banco Central do Brasil, indica a existência de um ou mais terminais de autoatendimento em um determinado lugar e é categorizada por município e por instituição financeira, o que permite, além de uma análise mais detalhada, observar onde foram consumidos os ATMs pelos bancos, entender diferenças internas a cada Unidade da Federação e algumas das estratégias locacionais das principais instituições financeiras existentes no país para esse objeto técnico.

O primeiro ponto a ser considerado é que as diferenças estaduais são mantidas, com concentração desses postos, em quantidade, nos Estados de São Paulo, Minas Gerais, Rio de Janeiro, Rio Grande do Sul, Paraná e Bahia. No entanto, ao se observar sua distribuição espacial interna aos estados um segundo ponto é possível de ser observado: embora os estados mais populosos possuam uma maior quantidade de PAEs, do ponto de vista da densidade de PAEs por 10.000 habitantes em cada unidade da federação, São Paulo (o estado com maior quantidade) não é o mais denso: as maiores densidades estão nos estados de Roraima (3,21 PAEs/10.000 habitantes), Rio Grande do Sul (2,58), Santa Catarina $(2,30)$, Espírito Santo (2,29), Mato Grosso do Sul $(2,27)$, Tocantins (2,16). São Paulo, como foi dito, o mais populoso, não é o mais denso: possui uma média de 1,80 PAEs por 10.000 habitantes, o mesmo acontecendo com o Rio de Janeiro que possui uma densidade de 1,63 $\mathrm{PAE} / 10.000 \mathrm{hab}$.

No entanto, essas aparentes diferenças de densidade não significam que todas as cidades do Estado possuam PAEs: há concentrações internas. Em todas Unidades da Federação, há uma densidade superior de PAEs nas capitais, com alguns casos muito discrepantes, isto é, com mais que o dobro nas capitais em relação aos seus respectivos Estados: é o caso de Vitória no Espírito Santo, de São Luís no Maranhão e de Belém no Pará. Outras possuem uma relação próxima a uma superioridade de 50\%: Goiânia, João Pessoa, Recife, Florianópolis, Sergipe e Tocantins. No entanto, é preciso ressaltar que, embora as densidades de São Paulo, Rio de Janeiro, Brasília e Belo Horizonte não sejam elevadas, essas três cidades concentram, sozinhas, 5.248 PAEs, ou seja, 15,86\% do total de PAEs em funcionamento no país em 2016. 
Esses dados permitem-nos pensar na força que tem essas cidades, especialmente as metrópoles que, pelas divisões do trabalho e pela própria diferenciação de renda nelas existentes, atraem não apenas os fixos mais complexos e diversificados (as agências e, no caso dos centros de gestão, as sedes e DC), como, igualmente, os menos complexos, por assim dizer, como os ATMs. Mais ainda: ajudam-nos a entender as estratégias atuais de uso do território pelos bancos. As desigualdades urbano-regionais, associada aos avanços tecnológicos do atual período e a automação constituem-se, nesse sentido, como importantes possibilidades para extração de valor e renda das regiões do país, permitindo que os bancos ofereçam "produtos e serviços financeiros em todos os locais sem necessariamente estar presente neles na forma de agência física" (CAMORCADI, 2013, p. 30).

Essa questão é de fundamental importância, na medida em que nos permite questionar as análises mais "ideologizadas": por não levarem em consideração os dados de localização dos fixos financeiros, alguns autores insistem em dizer que com a difusão de novas técnicas e a chamada desregulação dos mercados, a localização geográfica não mais importaria para as instituições financeiras. O que ocorre na realidade é o seu oposto: tornou-se possível uma estratégia definida territorialmente, tendo como ponto focal o conhecimento preciso dos lugares e das características inerentes de cada formação socioespacial. 


\section{CONSIDERAÇÕES FINAIS}

A automação bancária foi um fenômeno amplo, que envolveu diversos países, atividades econômicas, infraestruturas, agentes e processos. Buscou-se, ao longo deste trabalho, compreendê-la junto das dinâmicas da formação socioespacial brasileira, enquanto sistema técnico composto por artificialidades e intencionalidades, formas de fazer e de regular, que funcionam de forma solidária, isto é, utilizando-se e dando condições para que outros sistemas técnicos funcionem (SANTOS, [1996] 2002).

Nesse sentido, foi dada ênfase na análise do circuito espacial de produção de um de seus objetos técnicos mais importantes, os Terminais de Autoatendimento (Automatic Teller Machines - ATMs). O conceito de circuito espacial foi bastante operacional para a análise, uma vez que, além de considerar o espaço geográfico como uma instância ativa, permite estudar o processo produtivo - muitas vezes disperso geograficamente - em sua totalidade, isto é, desde a produção propriamente dita até a distribuição e o consumo (SANTOS, 1985). Nesse sentido, agentes (pessoas, empresas, instituições), materialidades (infraestruturas, meio construído, objetos técnicos), políticas públicas e fluxos de diferentes ordens (mercadorias e informações) foram considerados elementos intrinsecamente associados na difusão dos ATMs no território brasileiro.

A periodização permitiu-nos compreender de forma conjunta os processos de automação bancária, de formação do circuito espacial de produção e dos seus círculos de cooperação. Nesse sentido, pode-se dizer que esses foram importantes aspectos ligados ao processo reorganização do sistema bancário em escala nacional: da busca por uma maior eficiência e velocidade na contabilidade financeira, esses processos foram se transformando e ganharam dinamismo até que, nas décadas de 1970 e 1980, com a reserva de mercado e com a busca de diversos bancos pela incorporação de novos objetos técnicos, houve a formação do circuito espacial de produção de ATMs na formação socioespacial brasileira.

Nesse sentido, formou-se um conjunto de empresas que, apesar de diferentemente localizadas, configuraram o circuito espacial de produção dos Terminais de Autoatendimento e que passaram a fornecê-los aos diversos bancos 
presentes no Brasil. Tal circuito espacial, em conjunto com os diferentes círculos de cooperação que dele emergiram, foram de fundamental importância no entendimento de processos de expansão e desconcentração espacial de formas de atendimento e de serviços bancários, permitindo-nos desdobrar algumas questões urbanas e regionais que perpassam o território brasileiro na atualidade, além de ter permitido compreender a especificidade do papel cada vez mais proeminente da cidade de São Paulo no contexto nacional no atual período histórico.

O enfoque no conceito de sistema técnico, por sua vez, permitiu-nos compreender que a automação bancária não se deu num "vácuo", no qual existiria apenas a ação dos bancos sem considerar qualquer diferença regional existente no país. Foi visto que, ao longo do tempo, a constituição de cada região brasileira (com suas sucessivas divisões do trabalho, seus agentes, normatizações específicas etc.), e sua incorporação nos diferentes projetos governamentais influenciou a forma com que se deu a implantação e interligação dos diferentes fixos bancários, assim como a forma com que cada localidade do território nacional acabou por dominar ou ser dominada por outras.

Em ambos os casos, a atuação do Estado foi de extrema importância. De um lado, no circuito espacial de produção de ATMs e de seus círculos de cooperação, os seus projetos de industrialização, via substituição de importações, e de abertura comercial, com as políticas de aumento de importações, influenciaram a atuação dos agentes, seja favorecendo uma maior organização do circuito, seja uma reorganização da própria atividade bancária. Portanto, de outro lado, no sistema bancário brasileiro as normatizações existentes em cada período o influenciaram decisivamente. $\mathrm{O}$ estudo dos projetos e programas governamentais contribuíram para reforçar um entendimento do Estado como um importante regulador do sistema financeiro e de suas respectivas instituições.

Dentro dessa perspectiva é possível argumentar que os projetos estatais realizados ao longo da década de 1990 representaram uma importante inflexão, evidenciando as múltiplas facetas do neoliberalismo no Brasil, que, de acordo com o estudo empreendido, acabou por reforçar dinâmicas territoriais seletivas e excludentes, concentração de poder econômico e político, e um impulsionamento governamental da atuação de bancos estrangeiros no território brasileiro. 
A partir dos anos 2000 (e com mais força após 2002) o fortalecimento dos bancos, visto pelo exponencial aumento dos seus ativos, junto do aprofundamento do uso dos sistemas técnicos automatizados, permitiram uma expansão e flexibilização da topologia bancária como um todo, favorecendo uma maior presença dos fixos bancários nas diferentes regiões do país, assim como para recolher um maior volume informacional das populações e empresas, que, por sua vez, podem favorecer a implantação de novas políticas financeiras.

Por fim, o presente estudo permite pensar as diferentes qualidades do meio técnico-científico-informacional no Brasil, pelo viés dos sucessivos objetos técnicos que foram sendo produzidos e incorporados às redes bancárias. Em um primeiro momento, esses foram mais especializados no processamento de dados contábeis, necessitando uma divisão do trabalho para a transmissão e recebimento de informações. Posteriormente, com o desenvolvimento dos softwares e das capacidades de processamento de dados foi possível, a esses objetos, transmitirem e recolherem informações, com a necessidade de uma divisão do trabalho para a entrada de dados (os caixas das agências bancárias). Atualmente há um aprofundamento desse processo, com uma maior capacidade de transmissão, processamento e armazenamento de informações. 
ACCORSI, A. "Automação bancária e seus impactos: o caso brasileiro". Revista Brasileira de Administração, São Paulo, vol. 27, n 4, out-dez/1992. pp. 39-46.

Automação: bancos e bancários. Dissertação de Mestrado Departamento de Economia da Faculdade de Economia e Contabilidade da Universidade de São Paulo, 1990.

ANDRADE, M. C. Poder político e produção do espaço. Recife, Fundação Joaquim Nabuco/Editora Massangana, 1984.

ANGELO, I. FEBRABAN: 40 anos de participação. São Paulo, DBA Artes gráficas, 2007.

ANTAS JR, R. M. Complexos industriais, circuitos espaciais produtivos e direito reflexivo. Boletim Campineiro de Geografia, v. 5, n. 1, 2015. pp.53-71.

- Urbanização e os circuitos espaciais produtivos da saúde In: XV ENAMPUR, 2013, Recife. Desenvolvimento, planejamento e governança. Recife, 2013

ARROYO, M. "El territorio brasileño y la internacionalización de los circuitos de producción". IN: BERTONCELLO, R. y CARLOS, A. F, (comp.). Procesos territoriales en Argentina y Brasil. Buenos Aires: Instituto de Geografía/Facultad de Filosofía y Letras (UBA). 2003. pp. 315-335.

- Território brasileiro e mercado externo: uma leitura do Brasil na virada do século XXI. Tese de Doutoramento - Faculdade de Filosofia Letras e Ciências Humanas da Universidade de São Paulo, 2001.

AYRES, M. "Novos mercados na mira da Diebold". Revista Exame, 06 de julho de 2011. http://exame.abril.com.br/negocios/noticias/novos-mercados-na-mirada-diebold/

Banco Nacional de Desenvolvimento Econômico. "BNDES aprova financiamento de R\$ 142,6 milhões para Itautec". Disponível em: 
BARBOSA, D. 2012a. "Diebold Compra GAS Tecnologia no Brasil". Revista $\begin{array}{lllll}\text { Exame, } & 05 & \text { de } & \text { setembro }\end{array}$ http://exame.abril.com.br/negocios/noticias/diebold-compra-gas-tecnologia-nobrasil http://www.bndes.gov.br/SiteBNDES/bndes/bndes_pt/Institucional/Sala_de_Im prensa/Noticias/2007/20070618_not138_07.html.

2012b. "NCR faz três aquisições no Brasil". Revista Exame, 20 de junho de 2012. Disponível em: http://exame.abril.com.br/negocios/noticias/ncrfaz-tres-aquisicoes-no-brasil

BAPTISTA, M. A. C. "Política industrial e destruição produtiva". IN: Crise brasileira: anos 1980 e governo Collor. Co-edição Departamento Socioeconômico e Político da CUT (DESEP) e Instituto Cajamar (INCA), 1993.

BARIC, L. F. "Automação". IN: BOTTOMORE, T. \& OUTHWAITE, W. Dicionário do pensamento social do século XX. Rio de Janeiro: Jorge Zahar Ed., 1996.

BATISTA JR., P. N. BATISTA JR., P. N. O Brasil e a economia internacional: recuperação e defesa da autonomia nacional. Rio de Janeiro, Elsevier, 2005.

A economia como ela é...São PAulo, Boitempo Editorial, 2001.

. Da crise internacional à moratória brasileira. RJ, Paz e Terra, 1988.

BENAKOUCHE, T. "Redes de comunicação eletrônica e desigualdades regionais". IN: GONÇALVES, M. F. O novo Brasil urbano: impasses, dilemas, perspectivas. Porto Alegre, Mercado Aberto, 1995. pp. 227-238.

BLASS, L. M. da S. "Automação bancária: práticas e representações”. São Paulo em perspectiva, 7(4), out/dez 1993, pp. 81-89.

BOLAÑO, C. Indústria cultural, informação e capitalismo. São Paulo, Hucitec/Pólis, 2000.

BORGES, A. 2010. "Com dinheiro em caixa, Diebold avalia aquisições no país". Jornal Valor Econômico, 25 de março de 2010. Disponível em: 
http://www.valor.com.br/arquivo/815415/com-dinheiro-em-caixa-diebold-avaliaaquisicoes-no-pais

BORJA, J. \& CASTELLS, M. Local y global: la gestion de las ciudades en la era de la información. Taurus, Pensamiento, 1997.

BOUÇAS, C. \& CORTEZ, B. 2012. "Cultura do autosserviço avança no país". Jornal Valor Econômico, 18 de dezembro de 2012. Disponível em: http://www.valor.com.br/empresas/2943756/cultura-do-autosservico-avanca-nopais

BOUÇAS, C. 2014a. "ATMs recicladores estréiam no país". Jornal Valor Econômico, 04 de junho de 2014. Disponível em: http://www.valor.com.br/empresas/3573570/atms-recicladores-estreiam-no-pais 2014b. "Finalizada, fusão com Itautec abre frentes para OKI". Jornal Valor Econômico, 15 de maio de 2014. Disponível em: http://www.valor.com.br/empresas/3548062/finalizada-fusao-com-itautec-abrefrentes-para-oki

2013. "Mobilidade bancária exige criatividade em caixas eletrônicos". Jornal Valor Econômico, 13 de junho de 2013. Disponível em: http://www.valor.com.br/empresas/3159544/mobilidade-bancaria-exigecriatividade-em-caixas-eletronicos . 2011. "NCR inaugura fábrica em Manaus". Jornal Valor Econômico, 12 de novembro de 2009. Disponível em: http://www.valor.com.br/arquivo/793235/ncr-inaugura-fabrica-em-manaus BRIGATTO, G. 2015. "Wincor fecha área de caixas eletrônicos". Jornal Valor Econômico, 05 de agosto de 2015. Disponível em: http://www.valor.com.br/empresas/4164682/wincor-fecha-area-de-caixaseletronicos

2012. "Automação ganha relevância no varejo". Jornal Valor Econômico, 12 de julho de 2012. Disponível em: http://www.valor.com.br/empresas/2748642/automacao-ganha-relevancia-novarejo 
BRONZATI, A. 2014. "Bancos investem em caixas mais modernos". O Estado de São Paulo, 07 de junho de 2014. Disponível em: http://economia.estadao.com.br/noticias/geral,bancos-investem-em-caixas-maismodernos-imp-, 1507147.

BUENO, S. R. 2013. "Perto vai dobrar produção de terminais ponto de venda". Jornal Valor Econômico, 26 de março de 2013. Disponível em: http://www.valor.com.br/empresas/3060022/perto-vai-dobrar-producao-determinais-ponto-de-venda

CAMOCARDI, C. Z. Dinâmica estratégica de agências bancárias em um novo paradigma tecnológico: um estudo do caso brasileiro. Dissertação de Mestrado Escola de Economia de São Paulo (FGV/SP), 2013.

CANO, W. "América Latina: do desenvolvimentismo ao neoliberalismo". IN: FIORI, J. L. (org.) Estados e Moedas no desenvolvimento das nações, Petrópolis, Vozes, 1999. pp.287- 326.

CANO, W. Soberania e política econômica na América Latina. São Paulo, Editora Unesp, 1999.

Desequilíbrios regionais e concentração industrial no Brasil, 19301995. Campinas, Editora Unicamp, 1998.

CARRARA, A. M. "Cnab e Ciab - uma história de cooperação (depoimento)". In: CORREA, C. E.; MEIRELLES, F.; DINIZ, E. Tecnologia bancária no Brasil : uma história de conquistas, uma visão de futuro. São Paulo : FGVRAE, 2010. pp. 361-362.

CARDOSO DE MELLO, J. M. O Capitalismo tardio. São Paulo, Ed. Brasiliense, 1982,

CASSIOLATO, J. E. "A conexão entre usuários e produtores de alta tecnologia: um estudo de caso da automação bancária no Brasil". Ensaios FEE, Porto Alegre, vol. $13, \mathrm{n}^{\circ} 1,1992$. pp. 166-203.

CASTILLO, R. \& FREDERICO, S. "Espaço geográfico, produção e movimento: uma reflexão sobre o conceito de circuito espacial produtivo". Natureza \& Sociedade, Uberlândia, $\mathrm{n}^{\circ}$ 22, vol. 3, dez/2010. pp. 461-474. 
CASTILLO, R. Sistemas orbitais e uso do território: integração eletrônica e conhecimento digital do território. Tese de Doutoramento - Faculdade de Filosofia Letras e Ciências Humanas da Universidade de São Paulo, 1999.

CAVALHEIRO, N. Bancos Comerciais no Brasil (1964/1976) - crescimento e concentração. Dissertação de Mestrado - Departamento de Economia da Faculdade de Economia e Administração da Universidade de São Paulo, 1982.

CERNEV, A.; DINIZ, E. \& JAYO, M. "Emergência da quinta onda de inovação bancária". Proceedings of the Fifteenth Americas Conference on Information Systems, San Francisco, California August 6th-9th 2009, pp. 1-9.

COHN, G. "A forma da sociedade da informação". DOWBOR, L. et al. (orgs). Desafios da Comunicação, Petrópolis, Editora Vozes, 2000.. pp. 20-27.

COMPUTERWORLD. 2015. "Uso de biometria deverá gerar investimentos de US\$ 67,8 bilhões até 2024". Revista ComputerWorld, 7 de julho de 2015. Disponível em: http://computerworld.com.br/uso-de-biometria-devera-gerarinvestimentos-de-us-678-bilhoes-ate-2020

CONTEL, F. B. Território e finanças: técnicas, normas e topologias bancárias no Brasil. Tese de Doutoramento - Departamento de Geografia da Faculdade de Filosofia, Letras e Ciências Humanas (FFLCH-USP), 2006.

. "A topologia dos bancos comerciais no Brasil - aspectos de sua evolução no longo prazo e feições recentes". IN: LENCIONI, S. \& BLANCO, J. Argentina e Brasil: territórios em redefinição. Rio de Janeiro, 2016. pp. 39-60.

"A evolução do sistema financeiro brasileiro: uma leitura geográfica". IN: OLIVEIRA, M. P. de; COELHO, M.C.N. \& CORRÊA, A. de M. O Brasil, a América Latina e o Mundo: espacialidades contemporâneas. Rio de Janeiro, Lamparina, Anpege, Faperj, 2008.

- Território e finanças: técnicas, normas e topologias bancárias no Brasil. São Paulo, Anablume, 2011.

CORDEIRO, H. K. O centro da metrópole paulistana - expansão recente. São Paulo: IG-USP, 1980. 
“A ‘cidade mundial' de São Paulo e a recente expansão de seu Centro Metropolitano". Revista Brasileira de Geografia, 54 (3), 1992. pp. 05-26.

CORREAA, R. L. "Concentração bancária e os centros de gestão do território". Revista Brasileira de Geografia, IBGE, v. 51, n. 2, abr./jun, 1989. pp. 17-32.

COSTA NETO, Y. C. da. Bancos Oficiais no Brasil: origem e aspectos de seu desenvolvimento. Brasília, Banco Central do Brasil, 2004.

COSTA, M. C. da. Constrangimentos e mudanças no setor de telecomunicações no Brasil (1979-1995). Tese de doutoramento - Departamento de Ciências Políticas Faculdade de Filosofia, Letras e Ciências Humanas (FFLCH-USP), 1997.

DANTAS, M. Informação e trabalho no capitalismo contemporâneo. Lua Nova, n. 6, 2003. pp. 5-44.

O crime de Prometeu: como o Brasil obteve a tecnologia de informática. Abicomp, 1989.

DANTAS, V. Guerrilha tecnológica: a verdadeira história da Política Nacional de Informática. - Rio de Janeiro : LTC-Livros Técnicos e Científicos Ed., 1988.

DIAS, L.C. \& LENZI, M. H. "Reorganização espacial das redes bancárias no Brasil: processos adaptativos e inovadores". Cadernos CRH, Salvador, vol. 22, $\mathrm{n}^{\mathrm{o}}$ 55 , jan-abr/2009.

DIAS, Leila Christina. "Porque os bancos são o melhor negócio no país? Hegemonia financeira e geografia das redes bancárias". In: SILVESTRE, E. (Org.). Que país é esse? Pensando o Brasil contemporâneo. São Paulo: Ed. Globo, 2006, p. 27-62.

. "Redes: emergência e organização". In: CASTRO, Iná Elias; GOMES, Paulo César da Costa; CORRÊA, Roberto Lobato (org.). Geografia: Conceitos e temas. $3^{\mathrm{a}}$. ed., Rio de Janeiro: Bertrand Brasil, 2001. p. 141-162.

. "Redes Eletrônicas e novas dinâmicas do território brasileiro". IN: CASTRO, I. E. de; GOMES, P. C. da C. \& CORRÊA, R. L. Brasil: questões atuais da reorganização do território. Rio de Janeiro, Bertrand Brasil, 1996. pp.115-144. 
DIB, G. "O princípio de tudo (depoimento)". In: CORREA, C. E.; MEIRELLES, F.; DINIZ, E. Tecnologia bancária no Brasil : uma história de conquistas, uma visão de futuro. São Paulo : FGVRAE, 2010. pp. 44-49.

DICKEN, P. Mudança global: mapeando as novas fronteiras da economia mundial. Porto Alegre, Editora Bookman, 2010. $5^{\text {a }}$ edição.

DINIZ, C. C. "Impactos territoriais da reestruturação produtiva". In: RIBEIRO, L. C. de (org.). O futuro das metrópoles: desigualdades e governabilidade. Rio de Janeiro; Revan, Fase, 2000. pp. 21-62.

DINIZ, E. H. "Cinco décadas de Automação". GV Executivo, vol. 3, no 3, agoout/2004. pp. 55-60.

DINIZ, E. Uso da Web pelos bancos: comércio eletrônico nos serviços bancários. Tese de doutoramento apresentada à Escola de Administração de Empresas de São Paulo da Faculdade Getúlio Vargas (EASP/FGV), 2000.

DRSKA, M. 2011. "NCR e Scopus anunciam acordo para produção de ATM". Jornal Valor Econômico, 27 de julho de 2011. Disponível em: http://www.valor.com.br/tecnologia/202515/ncr-e-scopus-anunciam-acordo-paraproducao-de-atm

2012a. "Caixas eletrônicos de multimoedas é nova aposta de fabricantes". Jornal Valor Econômico, 27 de agosto de 2012. Disponível em: http://www.valor.com.br/empresas/2803794/caixas-eletronicos-de-multimoedase-nova-aposta-de-fabricantes

2012b. "Americana NCR compra companhia israelense de software". Jornal Valor Econômico, 29 de novembro de 2012. Disponível em: http://www.valor.com.br/empresas/2923396/americana-ncr-compra-companhiaisraelense-de-software

2013. "Na estratégia da Scopus, mobilidade ganha espaço". Jornal Valor Econômico, 15 de março de 2013. Disponível em: http://www.valor.com.br/empresas/3046296/na-estrategia-da-scopus-mobilidadeganha-espaco 
DUPAS, G. Crise econômica e transição democrática. 1983/1986 - a delicada trajetória brasileira. São Paulo, Editora Klaxon, 1987.

EGLER, C. \& BECKER, B. Brasil: uma nova potência regional na economiamundo. Rio de Janeiro, Bertrand Brasil, 1994.

EVANS, P. "Informática a metamorfose da dependência". Novos Estudos, Cebrap, n. 14, jun/1986, pp. 14-36.

EXAME. 2007. "Itautec integra todas as empresas soba a marca Tallard". Revista Exame, 29 de junho de 2007. Disponível em: http://exame.abril.com.br/negocios/noticias/itautec-integra-todas-as-empresas-detecnologia-sob-a-marca-tallard-m0132665/

FACCINI, C. "SID informática da Sharp pede concordata". Jornal Valor Econômico, 1 de outubro de 2001. Disponível em: http://www.valor.com.br/arquivo/1000028062/sid-informatica-da-sharp-pedeconcordata

FAJNZYLBER, P. A Capacitação tecnológica na indústria brasileira de computadores e periféricos: do suporte governamental à dinâmica do mercado. Dissertação de mestrado apresentada ao Instituto de Economia da Universidade Estadual de Campinas (IE/UNICAMP), 1993.

FEDERAÇÃO BRASILEIRA DE BANCOS (FEBRABAN). Pesquisa Ciab FEBRABAN 2012: O Setor Bancário em Números. São Paulo, CIAB/FEBRABAN, 2012a.

FEDERAÇÃO BRASILEIRA DE BANCOS (FEBRABAN). Pesquisa FEBRABAN de Tecnologia Bancária 2014. São Paulo, FEBRABAN, 2015.

FEDERAÇÃO BRASILEIRA DE BANCOS (FEBRABAN). Pesquisa FEBRABAN de Tecnologia Bancária 2014. São Paulo, FEBRABAN, 2014.

FEDERAÇÃO BRASILEIRA DE BANCOS (FEBRABAN). Pesquisa FEBRABAN de Tecnologia Bancária 2013. São Paulo, CIAB/FEBRABAN, 2013. FEDERAÇÃO BRASILEIRA DE BANCOS (FEBRABAN). Pesquisa FEBRABAN de Tecnologia Bancária 2012. São Paulo, FEBRABAN, 2012b. 
FERRAZ, E. 2002. "Quase um intocável". Revista Exame, 08 de novembro de 2002. http://exame.abril.com.br/revista-exame/edicoes/779/noticias/quase-umintocavel-m0052314

FRISCHTAK, C. R. Automação bancária e mudança na produtividade: a experiência brasileira. Pesquisa e Planejamento Econômico, agosto/1992. pp. 197240.

FUOCO, T. 2006. "Sistema de autenticação pelas veias da mão começa a ser adotado nos terminais do Bradesco". Jornal Valor Econômico, 21 de junho de 2006. Disponível em: http://www.valor.com.br/arquivo/506895/sistema-deautenticacao-pelas-veias-da-mao-da-fujitsu-comeca-ser-adotado-nos-terminais-dobradesco

2005. "Nas lotéricas, Diebold Procomp consegue seu $2^{\circ}$ maior contrato no país". Jornal Valor Econômico, 21 de março de 2005. Disponível em: http://www.valor.com.br/arquivo/453783/nas-lotericas-dieboldo-procompconsegue-seu-2\%C2\%BA-maior-contrato-no-pais

. 2004. "NCR espera salto na participação de mercado com produção local". Jornal Valor Econômico, 04 de março de 2004. Disponível em: http://www.valor.com.br/arquivo/405171/ncr-espera-salto-na-participacao-demercado-com-producao-local

2003. "Cobra relança sua marca em computadores e ATMs depois de 20 anos". Jornal Valor Econômico, 11 de junho de 2003. Disponível em: http://www.valor.com.br/arquivo/363363/cobra-relanca-sua-marca-emcomputadores-e-atms-depois-de-20-anos

FURTADO, C. Formação econômica do Brasil. Rio de Janeiro: Companhia Editora Nacional, 1982.

GEIGER, P. P. Evolução da rede urbana brasileira. Rio de Janeiro, Centro Brasileiro de Pesquisas Educaionais, 1963.

GOMES, C. Telecomunicações, informática e informação e a remodelação do território brasileiro. Tese de Doutoramento - Departamento de Geografia da Faculdade de Filosofia, Letras e Ciências Humanas (FFLCH-USP), 2001. 
GONÇALVES, R. Globalização e desnacionalização. São Paulo: Paz e Terra, 1999.

GUTIERREZ, W. "Cnab e Ciab - uma história de cooperação (depoimento)". In: CORREA, C. E.; MEIRELLES, F.; DINIZ, E. Tecnologia bancária no Brasil : uma história de conquistas, uma visão de futuro. São Paulo : FGVRAE, 2010. pp. 352-355.

HELENA, S. "A indústria de computadores: evolução das decisões governamentais". Revista de Administração Pública, Rio de Janeiro, n, 14, vol. 4, out/dez 1980, pp. 74-109.

HOFF, W. Automação bancária. Informatização no Banco do Brasil SA. Florianópolis: ICPG, 2003.

JAYO, M. Correspondentes bancários como canal de distribuição de serviços financeiros: taxonomia, histórico, limites e potencialidades dos modelos de gestão de redes. Tese de Doutoramento - Escola de Administração de Empresas (EAESPFGV ), 2010.

JINKINGS, N. Trabalho e resistência na "fonte misteriosa": os bancários no mundo da eletrônica e do dinheiro. Campinas: Editora da Unicamp, 2002.

JULIBONI, M. 2011. "Diebold vai muito além das urnas eletrônicas". Revista Exame, 06 de julho de 2011. Disponível em: http://exame.abril.com.br/negocios/noticias/diebold-vai-muito-alem-das-urnaseletronicas/

KAPNER, S. \& TREVISANI, P. 2012. "Caixas eletrônicos para o ladrão moderno". Jornal Valor Econômico, 27 de janeiro de 2012. Dispopnível em: http://www.valor.com.br/impresso/wall-street-journal-americas/caixaseletronicos-para-o-ladrao-moderno

LABASSE, J. "Les congrès, activité tertiaire de villes privilégiées". Annales de Géographie, 93e Année, No. 520 (Novembre-Décembre 1984), pp. 687-703. L'espace financier. Paris: Armand Colin, 1974. 
Les Capitaux et la Région. Étude Géographique. Essay sur le commerce et la circulation des capitaux dans la région lyonaise. Étude Géographique. Paris: Presses de la Fondation Nationale de Sciences Politiques, 1955.

LARANGEIRA, S. \& FERREIRA, V. "Excluídos e beneficiários dos processos de reestruturação: um estudo comparativo da regulação do emprego no sector bancário em Portugal e no Brasil". Revista Crítica de Ciências Sociais, nº 57/58, jun-nov/2000, pp. 53-85.

LARANGEIRA, S. "Reestruturação produtiva no setor bancário: a realidade dos anos 90". Educação e Sociedade, ano XVIII, nº 61, dez/97. pp.110-138.

LEE, M. J. Evolução global da indústria da TI (Tecnologia da Informação): uma abordagem comparativa do Brasil e da Coréia do Sul. Tese de Doutoramento Departamento de Geografia da Faculdade de Filosofia, Letras e Ciências Humanas (FFLCH-USP), 2004.

LENCIONI, S. "A metropolização do espaço: processos e dinâmicas". FERREIRA, A.; RUA, J.; MARAFON, G. J.; SILVA, A. C. P. da. Metropolização do espaço. Gestão territorial e relações urbanorurais. Rio de Janeiro, Consequência, 2013, pp. 17-34.

. "Cisão territorial da indústria e integração regional no Estado de São Paulo". IN: GONÇALVES, M. F. (et alli). Regiões e Cidades, Cidades nas Regiões. São Paulo: Edunesp/ANPUR. 2000. pp. 465-475.

. "Reestruturação urbano-industrial no Estado de São Paulo: a região da metrópole desconcentrada". Espaço e Debates, São Paulo, no 38, p. 54-61, 1994.

LIMA, R. R. de S. Complexo Eletrônico: a evolução recente e os desafios para o setor e para atuação do BNDES. IN: SOUSA, Filipe Lage de BNDES 60 anos: perspectivas setoriais, v. 1. Rio de Janeiro, 2012.

LOPES, F. \& BRIGATTO, G. 2014. "Bradesco vende fatia da Scopus para IBM". Jornal Valor Econômico, 30 de julho de 2014. Disponível em: http://www.valor.com.br/financas/3631268/bradesco-vende-fatia-da-scopus-paraibm 
LOPES, F. 2014a. "Caixa amplia fatia na Tecban para 10\%". Jornal Valor Econômico, 21 de julho de 2014. Disponível em: http://www.valor.com.br/financas/3619570/caixa-amplia-fatia-na-tecban-para-10 2014b. "Número de terminais da Tecban cresce 20\%". Jornal Valor Econômico, 15 de dezembro de 2014. Disponível em: http://www.valor.com.br/financas/3822152/numero-de-terminais-da-tecbancresce-20

MANDL, C. 2015. "Bancos liberam ATMs para não-cliente". Jornal Valor Econômico, 20 de março de 2015. Disponível em: http://www.valor.com.br/financas/3968886/bancos-liberam-atm-para-nao-cliente MARTIN, R. "The new economic geography of money". IN: MARTIN, R. (Org.). Money and the space economy. Chichester: John Wiley \& Sons, 1999. p. 3-27.

$$
2014 \text {. "Bancos retomam investimentos em canais digitais". }
$$

Disponível em: http://www.valor.com.br/financas/3571882/bancos-retomaminvestimento-em-canais-digitais

MELO, P. et al. Os mercados de automação bancária e comercial. Rio de Janeiro, BNDES Setorial, n. 11, p. 47-70, mar/2000.

MERGULHÃO, A. Industrialização paulista: como captar dois séculos de transformação? São Paulo, Editora Annablume, 2015.

MINELLA, A. C. "Bancos e banqueiros no Brasil: uma análise sociopolítica". In: MANDADORE, A. P. C. et all (orgs.). Sociologia econômica e das finanças: um projeto em construção. São Carlos, EdUFSCar, 2009. pp. 275-298

MIRANDA, Z. \& MIRRA, E. "Trajetória do deenvolvimento no Brasil". Revista USP, São Paulo, n. 93, mar/abr/mai, 2012. pp. 33-44.

MOREIRA, A. A. Arranjos tecnológicos da operação por meio de correspondentes bancários no Brasil, foco nos gestores de rede . Dissertação de Mestrado - Escola de Administração de Empresas (EAESP-FGV), 2011.

MOREIRA, T. 2011. "NCR planeja ampliar atuação no Brasil para além dos ATMs". Jornal Valor Econômico, 29 de julho de 2011. Disponível em: 
http://www.valor.com.br/arquivo/901037/ncr-planeja-ampliar-atuacao-no-brasilpara-alem-dos-atms

MOURA, A. "Bancos públicos estaduais e políticas macroeconômicas". In.: PINHEIRO, A. C. \& OLIVEIRA FILHO, L. C. de. Mercado de capitais e bancos públicos: análise experiências comparadas. Rio de Janeiro/São Paulo, Contra Capa Livraria/ANBID, 2007. pp. 305-318.

- "A abertura financeira externa: um breve relato da experiência brasileira". Revista Brasileira de Economia Política, vol. 1, nº 1, jan-mar/1981. pp.144-152.

NAKATANI, P. \& SABADINI, M. de S. "Sistema financeiro e mercado de capiais". In: MARAQUES, R. M. \& ,FERREIRA, M. R. J. O Brasil sob a nova ordem: a economia contemporênea. Uma análise dos governos Collor a Lula, São Paulo, Saraiva, 2010. pp. 75-102.

OLIVON, B. 2010. "Itautec recebe R\$ 69 milhões por Tallard". Revista Exame, 7 de julho de 2010. Disponível em: http://exame.abril.com.br/negocios/noticias/itautec-recebe-r-69-milhoes-tallard576632

PACHECO, C. A. "As reformas da política nacional de ciência, tecnologia e inovação no Brasil (1999-2002)". Santiago do Chile, CEPAL, dez/2007. .. A fragmentação da Nação. Campinas, Unicamp, 1998.

PALLOCI FILHO, A. "A nova política econômica". IN: VELLOSO, J. P. dos R. (coord.). Governo Lula: novas prioridades e desenvolvimento sustentado. Rio de Janeiro, José Olympio, 2003. pp. 63-60

PIRES, H. F. "Reestruturação Inovativa e Reorganização das Instituições Financeiras do Setor Privado no Brasil". Disponível em: http://www.cibergeo.org/artigos/GEOUERJ02.pdf (artigo originalmente publicado na Revista Geouerj, Rio de Janeiro, n 2 , 1997, pp. 65-79).

Reestruturação industrial e alta tecnologia no Brasil: as indústrias de informática em São Paulo. Tese de Doutoramento - Departamento de Geografia da Faculdade de Filosofia, Letras e Ciências Humanas (FFLCH-USP), 1995. 
RAFFESTIN, Claude. Por uma geografia do poder. São Paulo: Ática, 1993.

RIBEIRO, A. C. T.. Matéria e espírito: o poder (des)organizador dos meios de comunicação. In: PIQUET, R.; RIBEIRO, A. C. T. (Orgs.). Brasil, território da desigualdade: descaminhos da modernização, 1991. p. 44-55.

RODRIGUES, A. 2004. "Ferreira acha fundamental todos os bancos compartilharem terminais". Jornal Valor Econômico, 20 de janeiro de 2004. Disponível em: http://www.valor.com.br/arquivo/398787/ferreira-achafundamental-todos-os-bancos-compartilharem-terminais

RODRIGUES, L. 2001. "Cobra sobrevive à abertura e pretende dobrar a receita". Jornal Valor Econômico, 20 de fevereiro de 2001. Disponível em: http://www.valor.com.br/arquivo/1000002008/cobra-sobrevive-a-abertura-epretende-dobrar-receita

SALLUM JR, B. "Liberalismo e desenvolvimentismo no Brasil dos anos 90". In: ARBIX, G., ZILBOVICIUS, M. \& ABRAMOVAY, R. Razões e ficções do desenvolvimento. São Paulo, Editora da UNESP, Edusp, 2001. pp. 311-349;

SALOMÃO, A. 2005. "A lógica por trás da venda". Revista Exame, 25 de agosto de 2005. Disponível em: http://exame.abril.com.br/revistaexame/edicoes/0850/noticias/a-logica-por-tras-da-venda-m0080082

SANTOS, M. Metamorfoses do espaço habitado. São Paulo: Hucitec (2a ed.). 1988. . A urbanização brasileira. São Paulo, Hucitec, 1993. A natureza do espaço. São Paulo: Hucitec, [1996] 2002.

- "O dinheiro e o território". Geographia. Revista da Pós-Graduação em Geografia da UFF, ano 1, nº 1, 1999. pp. 7-13.

\& SILVEIRA, M. L. O Brasil: território e sociedade no início do século XXI. Rio de Janeiro: Editora Record, 2001.

SASSEN, S. "Localizando ciudades en circuitos globales". Revista Eure, vol. 29, número $88, \mathrm{dez} / 2003$.

SILVA JUNIOR, A. 2012. "Empresas lançam caixa eletrônico resistente à dinamite". Revista Exame, 20 de junho de 2012. Disponível em: 
http://exame.abril.com.br/tecnologia/noticias/empresas-lancam-caixa-eletronicoresistente-a-dinamite

SILVA, A. B. A contemporaneidade de São Paulo. Produção de informações e reorganização do território brasileiro. Tese de Doutoramento - Departamento de Geografia da Faculdade de Filosofia, Letras e Ciências Humanas (FFLCH-USP), 2001.

. 2011. "Itautec lança caixa eletrônico com tecnologia 3D". Revista

Exame, 16 de junho de 2011. Disponível em: http://exame.abril.com.br/tecnologia/noticias/itautec-lanca-caixa-eletronico-comtecnologia-3d

SILVEIRA, M. L. Um país, uma região: fim de século e modernidades na Argentina. São Paulo, FAPESP, LABOPLAN-USP, 1999.

SOUZA, N. A. de. Economia Brasileira Contemporânea: de Getúlio a Lula. São Paulo, Atlas, 2008.

STIGLITZ, J. \& GREENWALD, B. Rumo a um novo paradigma em economia monetária, São Paulo, Francis, 2004.

SUIZIGAN, W. "Estado e Industrialização no Brasil". IN: BERNARDO, A. C. et al. Brasil, desenvolvimento ameaçado: perspectivas e soluções. São Paulo, Editora da Universidade Estadual Paulista, 1989. pp. 281-294.

SUPERINTENDÊNCIA DE DESENVOLVIMENTO DA AMAZÔNIA. Amazônia: desenvolvimento e ocupação. Belém, Departamento Administrativo, Serviço de Documentação e Divulgação (SUDAM), 1968.

TAVARES, M. C. Império, território e dinheiro. In: FIORI, J. L. (org.) Estados e Moedas no desenvolvimento das nações, Petrópolis: Vozes, 1999. pp. 449-489.

TIGRE. P. B. Computadores brasileiros - indústria tecnologia e desenvolvimento. Rio de Janeiro, Campus, 1985.

VERDIER, E. "Traços específicos da informatização do trabalho bancário". Associação dos Geógrafos Brasileiros, Seleção de textos nº 16, jun/1986.

VIANA, F. Bradesco, 70 anos. Osasco, Fundação Bradesco, 2012. 
WARF, B. Global Geographies of the Internet. New York, London: Springer, 2013. 